INDUSTRY, THRIFT AND DIVINE REWARD:

\title{
AN EXAMINATION OF THE IDEOLOGY AND THEOLOGY \\ OF WORK IN NEW ZEALAND (1840-1992)
}

$$
\text { by }
$$

Philippa Kathryn Horrex

\author{
A thesis \\ submitted to the Victoria University of Wellington \\ in fulfilment of the \\ requirements for the degree of \\ Doctor of Philosophy \\ in Religious Studies \\ Victoria University of Wellington
}

1999 


\begin{abstract}
This study of the ideology and theology of work in New Zealand $1840-1992$, is in response to political statements in 1991 regarding the lack of a work ethic in New Zealand. The concept of the Protestant work ethic as advanced by Max Weber is explored as a background supposition, and is augmented by an examination of the Victorian "gospel of work" which, it is argued, was the basis of the work ethic in New Zealand.
\end{abstract}

Three time periods are explored within New Zealand history illustrating the contemporary work ideology among the politicians and the people, and reflecting on the churches' position in terms of work theology or ethics. The specific times examined in detail are the early colonial years (1840-1900), the Great Depression of the 1930 s, and the period of the major restructuring of the New Zealand economy (1984-92). In each instance secular sources are explored, and some church records are examined, in particular those of the Presbyterian Church of New Zealand. A detailed survey undertaken in 1991 of a group of public servants who were at the centre of much of the Government's economic restructuring (1984-92), is taken as evidence of the existence of a work ethic ideology among a middle class professional group.

The opinion is given that church in New Zealand has evolved from initially supporting the Victorian work ethic ideology of the capitalist system, to questioning its relevance in the late twentieth century but has contributed little to a contemporary theology of work. 
The conclusion is reached that historically New Zealanders have displayed a work ethic ideology which has been encouraged by the politicians. 


\section{ACKNOWLEDGMENTS}

The following people and organisations are acknowledged for their assistance in the research and production of this $\mathrm{PhD}$ : -

- Glenn Horrex, my husband, for his compilation of the Bibliography, and Appendices 4, 6 and 7, but more particularly, for his endless loving support and encouragement, cajoling and goading, challenging and debating, and his unswerving confidence that I could complete this thesis.

- Ministry of Agriculture and Fisheries, for the scholarship funding given between 1989-1992, for the use of their library interloan system, and for the time given by staff in helping to formulate and complete the 1991 research questionnaire (see Appendix 1 on Methodology for names and details). Thanks to Acting Director General, R. E. W. Elliott (1989) for recognising the potential value of this study, and his successor, Director General Russ Ballard, and also MAF Corp Director George Rogers, for support and encouragement, 1989-92

- Department of Scientific and Industrial Research Geology and Geophysics, for their gift of books, and for their contribution to the 1991 questionnaire.

- Interchurch Trade and Industry Mission (Central), for their support 1989-92

- Presbyterian Church of Aotearoa New Zealand, Community Based Ministry Training programme, for the provision of course fees 1992-94

- Patricia O'Donnell, for obtaining Roman Catholic material for me from the Wellington Diocese Archives and other sources.

- The Rev. Nancy Jean Whitehead, PCANZ, for allowing me access to submissions in response to the 1990 Nature of Work paper issued by the Joint 
Methodist-Presbyterian Public Questions Committee

- My colleagues in the Presbyterian Church of Aotearoa New Zealand who have provided me with material from their personal libraries, and given ongoing encouragement, with special acknowledgments to the Rev. Dr. John Franklin and the Rev. Dr. Robert Eyles.

- My children, Garreth, Kamael, and Meredith, and step-daughters, Katie and Nicole, for their tolerance and faith in me. 


\section{TABLE OF CONTENTS}

Abstract

Acknowledgments

Table of Contents

Introduction

Part One

Chapter 1

The Protestant Work Ethic - Myth or Reality

Chapter 2

"Know thy work and do it" - the new Gospel

Part Two

Chapter 3

"The toiler be lord" (1840-1900)

Chapter 4

"No pay without work" - the maxim of the Great Depression

A glimpse of Utopia - a brief interlude

Chapter 5

"To move attitudes, to change behaviour and foster a better work ethic" - the transforming of New Zealand

Chapter 6

The pursuit of an ideal - a market-driven public service

Part Three

Chapter 7

Restructuring the understanding of work

Chapter 8

" The Lord God took the man and put him in the garden of Eden to till it and keep it" -

Protestant Work Ethic or a theology of work?

Chapter 9

The Work Ethic in New Zealand Fact or Fiction? A Conclusion.

Appendix 1

Appendix 2 
Appendix 3 360

Appendix 4 363

Appendix 5 377

Appendix 6 380

Appendix 7 388

Bibliography 390 


\section{INTRODUCTION}

In the 1980 's the ideology of the work ethic came under scrutiny in New Zealand. In the face of considerable unemployment, and the constant restructuring of businesses and the public service, the government, business organisations (notably the Business Roundtable), various other community groups (for example, Rotary Clubs), and the Christian churches, began to ask questions about the whole ethos of work in New Zealand. ${ }^{1}$ It was not until 1991 however, that the opinion of many conservative, right wing New Zealanders was finally voiced: "New Zealanders' have a poor work ethic." The National Government's Minister of Finance, Ruth Richardson, acted as spokesperson, and over a period of two months declared her belief that only a revitalised work ethic would lead to renewed prosperity for the nation. ${ }^{2}$

The aim of this thesis is to examine, within the context of New Zealand's social and church history, the validity of Richardson's judgement that New Zealanders historically have a poor work ethic, and to prove that her verdict is wrong.

${ }^{1}$ During the period 1985 -1992 I worked for the Interchurch Trade and Industry Mission (ITIM) as an industrial chaplain at Ministry of Agriculture and Fisheries (MAF), and the Department of Scientific and Industrial Research Geological Survey, renamed Geology and Geophysics (DSIR GEO), in 1990. The meaning of work in constantly changing work environments became an issue of considerable importance during this time for those working as ITIM chaplains and for public service staff involved in organisational restructuring. This study of the work ethic in New Zealand resulted from conversations with ITIM chaplains, MAF management, and Department of Religious Studies lecturers, that took place in the late 1980s during increased debate regarding the value of the work ethic in light of the growing numbers of unemployed.

${ }^{2}$ Richardson, Ruth, Address to Wellington Chamber of Commerce, 27 March 1991, and State of the Nation Address, 3 April, 1991 
Because the original thesis regarding the work ethic by Max Weber was rooted in his interpretation of the effect of the teachings of the Protestant churches, I have chosen to examine the concept of the work ethic in New Zealand from a social and theological perspective, drawing on both the secular outlook of the community, internationally and regionally, and on the reflections of the New Zealand churches in light of local conditions and international academic discussions on the theology of work.

The methodology I have selected to use is loosely patterned on the work of the liberation theologians of South America, who use several academic disciplines to discern the contextual situation from which their theology arises. Leonardo and Clodovis Boff, in their book Introducing Liberation Theology, ${ }^{3}$ describe a method that includes a sociohistorico analysis, and a hermeneutic mediation. ${ }^{4}$ This is not inconsistent with Max Weber's own methodology of examining the present from the viewpoint of the past. ${ }^{5}$

The socio-historico analysis examines the context in which the situation arises. There has been a recognition among some theologians and church historians in New Zealand that socio-historical analyses are important if we are to understand who we are as a people. For example, theologian Gerald Fitzgerald commented in his book Christ in the

${ }^{3}$ Book titles identified in the main body of the thesis are in italics, as are all quotations in this thesis. Bolded words in the body of the thesis are either to add emphasis to a point, or will be identified as the titles of articles or essays.

${ }^{4}$ Boff, Leonardo and Clodovis. Introducing Liberation Theology, p 24

5 Chalcroft, David, Bringing the text back in: on ways of reading the iron cage metaphor in the two editions of The Protestant Ethic, in Jay, Larry J., \& Reed, Micahel, (eds), Organizing Modernity, p. 17 
Culture of Aotearoa-New Zealand: -

We in Aotearoa need to gather up our history as a nation and come to grips with our culture. On the one hand, this means a genuine receptivity to our past and an awareness of its impact on contemporary life in this country. On the other hand, this means an open criticism of the inadequacies, injustices, and mistakes of the past, many of which still influence social and political life today. ${ }^{6}$

Religious historian, Peter Lineham, has endorsed this view, pointing out that there are significant overlaps between religious, social and political history. ${ }^{7} \mathrm{He}$ goes on to observe: -

Difficult but important intellectual issues remain to be unravelled; above all, in interpreting the role which emerged for religion in the context of a society founded on an explicitly secular basis. ${ }^{8}$

In this thesis the issue is the situation of work in New Zealand. The socio-historico analysis undertaken involves consideration of the attitudes towards work of the early settlers, the effect of the work ethic on attitudes during the Great Depression of the $1930 \mathrm{~s}$, and the debate surrounding work during the economic restructuring of New Zealand 1984-92, along with its effect on a particular group of workers. The role of the churches during each of these periods will be examined in light of the social and political context.

The people involved in either complying with the work ethic ideology, or choosing to

${ }^{6}$ Fitzgerald, Gerald Patrick, Christ in the Culture of Aotearoa-New Zealand, p. 35

${ }^{7}$ Lineham, Peter, Religion, in Davis, Colin, \& Lineham, Peter, (eds), The Future of the Past. Themes in new Zealand History, .4

8 ibid, p. 5 
ignore it, that is, the workers, are more than simply what social analysts such as economists, sociologists, and anthropologists, can tell us about them. For example, what is "work" for the person working eight hours or more per day, and what is it for an economist? For the latter it is usually a simple category or a statistical calculation, whereas for the people, "work" means drama, anguish, dignity, security, exploitation, exhaustion, life - a whole series of complex and even contradictory perceptions. ${ }^{9}$ The study of a group of public service workers made in 1991 will provide a limited glimpse into the perceptions and ideology of a particular sector of middle class New Zealand workers within a specific historical setting, and will give some understanding of what work means in the "popular wisdom" of contemporary New Zealanders undergoing considerable change, both from a secular and religious viewpoint. ${ }^{10}$

This socio-historico examination is vital to the rest of the process. Silvano Burgalassi, in his essay Towards a Theology of Man as Worker, ${ }^{11}$ comments that in the past there has been a tendency for theologians studying work to ignore the subjective conditions of workers. Instead they have tended to concentrate only on theological reflection which incorporates Biblical study, the social teaching of the church, and previous theological assertions about work. This has resulted in learned reflection on...work produced by individuals who are incapable of understanding the full implications of work conditions. ${ }^{12}$ Burgalassi's suggestion that theology should start with the real

9 Boff, p. 30-31

${ }^{10}$ The methodology for this survey can be found in Appendix 2

11 Burgalassi, Silvano, in Baum, Gregory (ed). Work and Religion

12 ibid, p. 103 
conditions of the workers and then go on to see how these make it possible (or perhaps easier) to use the aids provided by theological and religious data in order to arrive at a coherent Christian view, ${ }^{13}$ therefore supports the use of socio-historico interpretation to move on to the second step of hermeneutic mediation.

Other theologians have supported this change of theological method, and there has been a call for theological discussion about work to come down from the rarefied atmosphere of theological academia into the common currency. ${ }^{14}$ Too often it is observed, philosophies of work have not been discussed from the point of view of the actual workers at the "sharp end" of work, but from the perspective of writers who have not had the experience of having to work to survive. ${ }^{15}$ There is a need for contemporary theology examining any issue to get away from a theology preoccupied with abstract and often abstruse questions. ${ }^{16}$

If theology presupposes the experience of the people, ${ }^{17}$ then hermeneutics needs to take into account the articulation of the faith that reflected (or still reflects), the situation of the people, in this case the workers. In the case studies in this thesis I will therefore outline the theology, social teachings of the New Zealand churches, and ideology of the period regarding work, as represented by contemporary writings, including fiction and

13 ibid, p. 104

${ }^{14}$ Raines, John C., \& Day-Lower, Donna C., Modern Work and Human Meaning, p. 103

15 Bleakley, David, (1983),Work: The Shadow and the Substance, p. 35

${ }^{16}$ Fitzgerald, p. 8

17 Amirtham, Samuel, and Pobee, John S.(eds). Theology by the People, p.13 
church records, as well as scholarly interpretation. I do not intend to formulate a theology of work from the New Zealand perspective in this study, but to comment on how the churches have reacted throughout New Zealand's history to the notion of the work ethic encapsulated in the conventional ideologies of work from the different eras. Any hermeneutical mediation attempted is more in line of a critique of the lack of a genuine local theological exploration of the ideology of work.

An understanding of the theory of the Protestant work ethic is the starting point for this thesis, for the veracity of a work ethic in New Zealand cannot be measured without insight into its assumed origins. Despite the controversy surrounding the authenticity of Max Weber's hypothesis, it is my contention that an ideology of work, supported by the establishment churches, found its way to colonial New Zealand where it took root and flourished in a secular society as a work ethic. The case studies will demonstrate that the ongoing influence of this Victorian work ideology throughout the twentieth century is found reflected in the attitudes of government politicians in both the 1930s, and the 1980 s to early 1990 s, and in the responses given by the group of public servants surveyed in late 1991. The ongoing deliberation of the churches about work and its theological meaning over the twentieth century, also gives an indication of the durability of the notion of work as a sacred necessity for humankind. The survival to this day of a work ideology that encompasses evidence of what is known as a Protestant work ethic, is an indication of its potency, at least in some sectors of New Zealand society.

In line with the methodology of a socio-historico analysis, Part One of this thesis is a discussion of Weber's theories, and an examination of British Victorian work values, 
both secular and theological, as a basis for the ongoing discussion regarding the existence of a work ethic in New Zealand 1840-1992.

Part Two involves a study of the work attitudes of the early Victorian settlers, followed by studies of two critical times in the employment history of New Zealand, ${ }^{18}$ that is the 1930 's, and the period 1984-1992. ${ }^{19}$ The nineteenth century material, ${ }^{20}$ and that regarding the $1930 \mathrm{~s}$, includes both secular and theological observations, while the two chapters specifically examining the 1984-92 period and its political and social background, will concentrate solely on secular commentaries of the period. ${ }^{21}$ Portions of the research survey of public servants is included in this section as firstly, an illustration of contemporary attitudes towards work in a changing environment, and secondly as a reflection of the durability of the nature of the work ethic ideology over one hundred and fifty-two years.

Part Three examines the changing ideology, both secular and religious, internationally

18 The choice of these two periods of New Zealand history is based on the notion that only when there is a crisis regarding employment, does the idoleogy of work come under real scrutiny.

19 The cut off date of 1992 was deliberately chosen because of the remodelling in that year of the technological division of the Ministry of Agriculture and Fisheries, and the divisions of the Department of Scientific and Industrial Research, into Crown Research Institutes. The study of public servants used to reflect on the effect of changing employment, economic and social patterns on work ideology in the late twentieth century, revolved around the imminent occurrence of that particular restructuring.

${ }^{20}$ The original theological material from nineteenth century New Zealand that I have had access to has been somewhat limited, therefore I have tended to only refer to published material.

${ }^{21}$ The reaction of the New Zealand churches to events in this period, and their comments on work ideology are discussed in Part Three of the thesis. 
and regionally, surrounding work in the latter part of the twentieth century, and makes some comment on the role of the churches in New Zealand during this time. Within the context of issues raised in secular and theological studies of work, the survey material examines the outlook of the group examined, confirming a general lack of religious reasoning behind the commitment to work, despite an identifiable measure of the existence of a work ethic among survey respondents.

A final conclusion confirming the existence of the work ethic in New Zealand, and disputing Richardson's claim of a decades old poor work ethic, is presented, ascribing the work ethic ideology to an enduring secular conviction in the value of hard work initially held by the majority of the settler population, but then systematically encouraged by the politicians from the mid-1800's to the later years of the twentieth century, in both New Zealand and other western countires. The 1991 survey material is used to demonstrate the ongoing existence of a work ethic in New Zealand, at least among one section of the population, and to give some insight into the lack of religious influence on work attitudes in the late twentieth century. The tenacity of work ethic ideology in a society generally described as secular is commented on. 
PART ONE 


\section{CHAPTER 1}

\section{The Protestant Work Ethic - Myth or Reality?}

When Theory $K$ was published in 1986, its authors claimed that one of the four main barriers to excellence in the New Zealand business world was the poor work ethic of the New Zealand people.' A few years later, in 1991, the Minister of Finance, Ruth Richardson, stated in a speech to the Lincoln and Hornby Rotary Clubs, A decades-old, poor managerial and work ethic is the reason why so many New Zealanders are now on the breadline. ${ }^{2}$

For many New Zealanders however, there is an underlying belief that New Zealand was founded principally on the Protestant work ethic of our colonial ancestors. ${ }^{3}$ Perhaps the discrepancy between the academic, political and popular views is due to the ambiguity of the very term "Protestant work ethic", compounded by the tendency to use the term as a talisman of sorts without any real understanding of its historical roots or meaning. Originating with the work of Max Weber, the term has come to be referred to as what one of Weber's critics, Kurt Samuelsson, calls a self-evident truth, ${ }^{4}$ and is used frequently

${ }^{1}$ Inkson, K. (et al), Theory $K, \mathrm{p} .2$

2 Ruth Richardson, A State of the Nation Speech to the Lincoln and Hornby Rotary Clubs, 3 April, 1991

3 The popular press made this claim in the late 1980 's, particularly, More Magazine, December, 1987, in an article entitled Back to Fundamentals by Jeff Hayward. Hayward actually states that New Zealand was founded on the largely Protestant work ethic of our colonial forebears. p. 208

${ }^{4}$ Samuelsson, Kurt, Religion and Economic Action, p. 4 
without any reference to its author. For example, when politicians refer to the concept of the work ethic, it appears that their perception involves a diligent attention to work, ignoring the religious, historical, and psychological beliefs relating to it.

Michael Rose, in his book Re-working the Work Ethic, defines the work ethic in modern terms as embracing:-

(i) individualistic striving for success; ( ii) willingness to postpone immediate pleasures in order to build up a store of virtue and money ("deferred gratification"); ( iii ) acceptance of a moral obligation to perform work diligently however menial the task; ( iv) dutiful compliance with the just order of an employer; and, ( $v$ ) the importance of work, in life as a whole, as a source of meaning and a sense of personal worth ("work centredness").

The extent to which such a definition can be applied to the working population of New Zealand is obviously debatable if we are to believe the words of Inkson et al, and Richardson, but the fact that the notion of the Protestant work ethic has survived into the late twentieth century thought of business and political leaders in New Zealand regardless of whether they understand its origins, is significant. ${ }^{6}$

\section{${ }^{5}$ Rose, Michael, Re-Working the Work Ethic, p. 12}

6 It is not surprising that this concept has survived in academia, largely due to the seemingly endless scholastic discussion on Max Weber's hypothesis regarding the Protestant work ethic and the origins of the "Spirit" of capitalism. It might seem surprising however, that non-academics should so readily grasp the concept and apply it to a secular society. The survey of public servants I conducted in late 1991, showed that $60 \%$ of the respondents had heard of the work ethic, and over $50 \%$ of this group when asked to define the work ethic were able to do so in terms which reflected to some extent components of Michael Rose's definition. Understanding of the general concept therefore appears to be relatively common among that portion of New Zealand society which can be described as "professional" and middle class. 
Before any real discussion can occur about the place of the Protestant work ethic in New Zealand however, the origin and theory of the concept needs to be examined. In light of the considerable debate over almost a whole century about its veracity, the question should be asked "Is the Protestant work ethic a cultural myth, or does it really exist?" It is not the intention of this chapter to scrutinise in depth all facets of Max Weber's work The Protestant Work Ethic and the Spirit of Capitalism, but rather to concentrate on the issues surrounding his hypothesis of a Protestant ethic pertaining to work, which is at the heart of his argument concerning the rise of a "spirit" of capitalism. ${ }^{7}$

It is important to recognise that Weber was writing in the context of his own time, the late nineteenth/early twentieth centuries of Europe. Ephraim Fischoff points out in his paper examining the Weber controversy, that Weber's primary object in all his writing was to understand contemporary European culture, especially modern capitalism. ${ }^{8}$ As an heir to the historical school... and the Marxist tradition, ${ }^{9}$ Weber's attempts to understand the world in which he found himself are rooted in,

viewing the past from the perspective of the present and the present from the perspective of the past.....For Weber, then, a characteristic feature of modern culture is the intertwining of various inheritances from the past..$^{10}$

${ }^{7}$ I will refer to both Weber's The Protestant Ethic and the Spirit of Capitalism, and Economy and Society in regards to these issues, recognising that the earlier essay was only meant as an exploratory discussion.

8 Fischoff, Ephraim, The Protestant Ethic and the Spirit of Capitalism, Social Research, Vol. 2, 1944, p. 61

9 ibid

10 Chalcroft, p. 17. Marshall, Gordon, Presbyteries and Profits, similarly discusses Weber's need to specify the origins of an orientation to everyday life, or 'world view,' and his identification of these in the doctrinal and ethical principles of an earlier belief system and their psychological implications. (p.21) 
Weber claimed from the context of the late nineteenth century that there was an obvious connection between Protestantism and economic achievement, ${ }^{11}$ and proceeded to look back to the Reformation, and the seventeenth and eighteenth centuries, to find explanations for the ethos which allowed this to happen. ${ }^{12}$

There has also been conjecture that Weber's attempts to trace the origins of the "spirit" of capitalism to religion, were based in his own personal situation. In contemporary terms, Weber was a "workaholic". He had compulsive work habits which he personally regarded as a pathological characteristic of his identity, ${ }^{13}$ and it has been suggested that his investigation into ascetic work habits may have been more than merely an academic exercise. ${ }^{14}$ It is claimed that Weber's relationship with his parents had much to do with his own work habits, and that: -

...by identifying the work ethic of his mother's Calvinist ancestry as a device which formerly gave evidence of a divine grace but now served only as a "housing hard as steel", Weber was focusing his intellect on his own experience in order to liberate himself from it and to interpret the history of the modern world; he was perceiving the historical dilemma of his personal dilemma. ${ }^{15}$

\footnotetext{
11 Weber, Max, The Protestant Ethic and the Spirit of Capitalism, (1985), p.35

12 Nipperdey, Thomas, Max Weber, Protestnstism, and the Context of the Debate around 1900, in Lehmann,Hartmut, \& Roth, Guenther, (eds), Weber's Protestsnt Ethic. Origins, Evidence, Contexts, places Weber into the context of German society and thought of the late nineteenth century. He remarks that it needs to be remembered that there was a tendency at the time to explain world history, and its political and social differences, in terms of religion. (p.77)

${ }^{13}$ Mitzman, Arthur, The Iron Cage: An Historical Interpretation of Max Weber,
pp. 171-2

14 ibid

15 ibid, pp.173-4
} 
If there is any credence to this theory about Weber's motivation for his work, a possible reflection of this self-analysis may be found in his own words. He observed that if the people of the day were asked,

what is the meaning of their restless activity, why they are never satisfied with what they may have, thus appearing so senseless to any purely worldly view of life, they would perhaps give the answer, if they know any at all: "to provide for my children and grandchildren." But more often, and since that motive is not peculiar to them, but was just as effective for the traditionalist, more correctly, simply: that business with its continuous work has become a necessary part of their lives. That is in fact the only possible motivation, but it at the same time expresses what is, seen from the view-point of personal happiness, so irrational about this sort of life, where a man exists for the sake of his business, instead of the reverse. ${ }^{16}$

Within the context of his time, it must be said that Weber's deduction that there was a close connection between religion values and society was not original. ${ }^{17}$ What was original, was his thesis that Protestantism and capitalism were related specifically through the doctrines of calling and predestination. Pre-Weber literature, according to Jacob Viner, ignored these elements in Protestant theology, and never connected them to the rise of capitalism, although there was,

almost universal agreement, before Weber, however, that there was a close historical association between Protestantism and the development of capitalism
in its modern forms. ${ }^{18}$

It was Weber's opinion that the tendency for Protestants to have developed a greater

${ }^{16}$ Weber (1985), p. 72

${ }^{17}$ Nipperdey, in Lehmann and Roth (eds), p. 73; Viner, Jacob, Religious Thought and Economic Society, p.154

18 Viner, p. 154 
economic rationalisation than Catholics, ${ }^{19}$ must be rooted in their differences regarding other-worldliness asceticism and inner-worldly asceticism. By "asceticism" Weber meant, an attitude toward salvation, which is characterised by a methodical procedure for achieving religious salvation..$^{20}$ The other-worldliness of Catholicism therefore, which was characterised by monasticism or a withdrawal from the world, meant a worldrejecting asceticism, a way of attempting to find salvation by recoiling from family, possession of goods, and political and economic activities. ${ }^{21}$ Accordingly, in Weber's opinion, a Catholic was more likely to demonstrate an indifference to the good things of this world, ${ }^{22}$ as compared to the Protestant who embraced an inner-worldly asceticism of participation in the world as a means to salvation.

In Weber's view, the Reformation had been the catalyst for this change in precept. He writes: -

Christian asceticism, at first fleeing from the world into solitude, had already ruled the world which it had renounced from the monastery and through the Church. But it had, on the whole, left the naturally spontaneous character of daily life in the world untouched. Now it strode into the market-place of life, slammed the door of the monastery behind it, and undertook to penetrate just that daily routine of life with its methodicalness, to fashion it into a life of the world, but neither of nor for this world. ${ }^{23}$

It was Martin Luther's re-interpretation of the doctrine of "calling" (Beruf) according to

${ }^{19}$ Weber, (1985), p. 40

${ }^{20}$ Weber, Max, Economy and Society, (1978), p. 541

${ }^{21}$ ibid, p.542

${ }^{22}$ Weber, (!985), p. 40

${ }^{23}$ ibid, p. 154 
Weber, that took asceticism into the world, and which Weber saw as the central dogma of all Protestant denominations. ${ }^{24}$ Monastic asceticism according to Luther, was not the way to please God; instead Luther advocated a life based on fulfilling the obligations placed upon the individual in the world through his or her calling to a particular position, or station, in life. Every calling was by God's mandate and only through executing the duties inherent in that calling could an individual live acceptably in God's eyes. ${ }^{25}$ According to Weber, this teaching caused an increase of religious sanction for worldly labour as compared to the pre-Reformation Catholic stance. ${ }^{26}$ Whereas, prior to the Reformation only those regarded as remiss in their ethical thinking would consider a career in business, the doctrine of calling now gave permission for the individual to strive for success in whatever station of life he or she found themself. ${ }^{27}$

Weber points out in his book Economy and Society, that this ethic vocation, was the unique creation of ascetic Protestantism alone ${ }^{28}$ but it did not stand apart. Only with the added concept of predestination did the ethic of vocation become the driving force which Weber claims is behind the spirit of capitalism. The emphasis placed on predestination by John Calvin and later Calvinistic "divines," such as Richard Baxter, according to Weber, provided a further reason for the individual to strive at his appointed calling in life, for it was only through hard toil in a divinely ordained activity

24 ibid, p. 80

25 ibid, p. 81

26 ibid, p. 83

${ }^{27}$ Weber (1978), p. 587

28 ibid, p. 556. 
that salvation could be assured. The doctrine of predestination meant however, that there was no guarantee that the individual was one of the elect as Weber points out.

Predestination provides the individual who has found religious grace with the highest possible degree of certainty of salvation, once he has attained assurance that he belongs to the very limited aristocracy of salvation who are the elect. But the individual must find certain indices (Symptome) by which he may determine whether he possesses this incomparable charisma, inasmuch as it is impossible for him to live on in absolute uncertainty regarding his salvation. ${ }^{29}$

The anxiety engendered by the uncertainty of that grace became, according to Weber, the psychological sanction for hard work ${ }^{30}$ while success in a worldly occupation became a sign of grace, of God's blessing.

Idleness, or an unwillingness to work, became symptomatic in Calvinist thought, of a lack of grace. ${ }^{31}$ The expectation was that every person would strive for success in the calling God had commanded for them, for according to Weber, Calvinism never ceased to stress the notion that a man proved himself exclusively in his vocational work. ${ }^{32}$ The paradox of Calvinist thought was reflected in the belief that while accumulated wealth was seen as ethically wrong, because it invited a sinful enjoyment of life and hence, idleness, it was also regarded as a fruit of labour in a calling, ${ }^{33}$ and a sign of God's blessing. While utilisation of wealth for luxuries, and the enjoyment of material assets,

\footnotetext{
${ }^{29}$ ibid, p. 573

${ }^{30}$ Weber (1985), p. 178

${ }^{31}$ ibid, p. 159

${ }^{32}$ Weber (1978), p. 588

${ }^{33}$ Weber (1985), p. 172
} 
were frowned upon by ascetic Puritans, Weber claims,

on the other hand, they approved the rational and utilitarian uses of wealth which were willed by God for the needs of the individual and the community. They did not wish to impose mortification on the man of wealth, but the use of his means for necessary and practical things. ${ }^{34}$

According to Weber, the limitation on consumption plus the encouragement of accumulation of profits, led to an ascetic compulsion to save, and therefore to an increase in wealth, which in turn allowed a productive investment of funds. ${ }^{35}$ From this spirit of Protestant asceticism therefore, was birthed Weber's spirit of capitalism.

One writer has questioned whether the theory in The Protestant Ethic and the Spirit of Capitalism initiated an important breakthrough or a blind alley, ${ }^{36}$ but given the years of intellectual discussion it has provoked, it appears Weber kindled an intense reaction which can only be described as significant, regardless of his theory's accuracy. The survival of Weber's theory, despite numerous attempts since the time of its publication to disprove it, is truly remarkable. This endurance however, does not secure the theory as a reality, despite the fact that it seems to have taken on the characteristics of what Richard Means calls received doctrine. ${ }^{37}$

Writing in the mid-1960s Means describes received doctrine as occurring when a social

34 ibid, p. 171

35 ibid, p. 172

36 Poggi,Gianfanco, Historical Viability, Sociological Significance, and Personal Judgment, in Lehmann and Roth (eds), citing Barrington Moore Jr, p. 295

37 Means, Richard, Weber's Thesis of the Protestant Ethic: The Ambiguities of Received Doctrine, The Journal of Religion, Vol. XLV, No. 1, January, 1965, p. 1. 
theory becomes an unanalyzed article of faith for at least one group of intellectuals, (in this instance, sociologists), and there is a failure to question the nature of the original data as well as an avoidance of an analysis of the basic logical structure of the theory per se. ${ }^{38}$ Sociology students, he says, are presented with Weber's theory as being an absolute truth, with little or no exposure to the controversy surrounding the theory. ${ }^{39}$ Thirty years later, Richard Hamilton was to write in his book The Social Misconstruction of Reality: -

The Protestant ethic thesis appears to be a social misconstruction...This misconstruction, the transformation of the hypothetical into a confirmed conclusion, is found also in the work of subsequent scholarly (and not so scholarly) writers... Weber and his supporters have invested the hypothesis with validity and have accorded world-historical significance to the Protestant
ethic.

He goes onto to point out that of a study of fifteen contemporary sociology textbooks giving summaries of Weber's theory, only eight give any indication that there is debate surrounding it. ${ }^{41}$

The debate, nevertheless, is extensive, despite the tendency of some sociologists to ignore it and behave as if Weber's theories are self-evident truths to be cited without being tested. ${ }^{42}$ The fact that it is mainly historians who have launched the attacks may be part of the reason for the indifference of sociologists to the critiques of Weber's work,
${ }^{38}$ ibid
39 ibid, p. 6
${ }^{40}$ Hamilton, Richard, The Social Misconstruction of Reality, p. 88
41 ibid, p. 92
${ }^{42}$ Samuelsson, p. 5 
for sociologists it would appear, do not study history. ${ }^{43}$ Admittedly historians may not have totally discredited Weber's thesis, but as Richard Means points out, they have certainly modified it to the extent of making it highly problematic whether or not it is true. ${ }^{44}$ Secondly, most sociologists, according to Means, have never taken the time to read Calvin or his followers, ${ }^{45}$ and as a result they are unaware of Weber's theological mistakes which are a major cause for concern among church historians and theologians. ${ }^{46}$

Although it seems that Weber's theories are still supported enthusiastically, and without question, by many sociologists, Hamilton points out that same enthusiasm has not been shared by specialist historians. ${ }^{47}$ Perhaps the primary problem for historians is the lack of evidence in Weber's thesis. ${ }^{48}$ Weber is accused of oversimplification, ${ }^{49}$ making unsubstantiated claims, ${ }^{50}$ generalising ${ }^{51}$ and impreciseness. ${ }^{52}$ His methodology is also

${ }^{43}$ Means comments that sociologists have some scientific obligation to familiarize themselves with what historians have to say on the matter (p. 2)

${ }^{44}$ ibid, p. 3

${ }^{45}$ ibid

${ }^{46}$ For brief comment on this issue, see MacKinnon, Malcom, The Longevity of the Thesis, in Lehmann and Roth (eds), p. 211; Marshall,Gordon, In Search of the Spirit of Capitalism, (1982), p. 121; Giddens, Anthony, in the preface to Weber (1985), p. xxiii

${ }^{47}$ Hamilton, p. 208

${ }^{48}$ Oakes, Guy, The Thing That Would Not Die: Notes on Refutation, in Lehmann and Roth (eds), p. 289

${ }^{49}$ Tawney, H. R., Religion and the Rise of Capitalism, p. 313; Fischoff, p. 73; Hudson, Winthrop, Puritanism and the Spirit of Capitalism, in Green, Robert, (ed), Protestantism and Capitalism. The Weber Thesis and Its Critics, p. 56

${ }^{50}$ Poggi, p. 83; Fischoff, p. 70

${ }^{51}$ Samuelsson, p. 148 
called into question, especially the extreme vagueness of his concepts, ${ }^{53}$ and his lack of alternative research strategies. ${ }^{54}$ In the light of such statements a closer examination of the principal areas of criticism appears to be in order before any conclusion can be drawn about the reality or mythology of the Protestant work ethic.

One of the primary disputes regarding Weber's thesis has been his claim that there was a marked difference not only between pre-Reformation Catholics and post-reformation Protestants in their economic rationalisation, but also between the Catholics and Protestants of later centuries. ${ }^{55}$ A brief examination of the history of the ideology of work may be of value in analysing this assertion. An ideology of work revolves around the understanding at a particular time, of the division of labour, and society's attitudes to work. All evolved societies, according to Michael Rose, manifest an elaborate division of labour, and provide explanations for the phenomenon of work itself, associated with meaning and values. ${ }^{56}$ For example, to the Greeks and Romans, work, hard labour, and subordination to raw economic need or to a master's orders, was inherently degrading, a curse. ${ }^{57}$ To the ancient Hebrews, work was considered a curse, a punishment for Adam and Eve's disobedience, but it was not the imposition of work

52 ibid

53 ibid, p. 150

54 Poggi, pp. 80-1

${ }^{55}$ Weber, (1985), p. 35

${ }^{56}$ Rose, p. 25

57 ibid, p. 28 
as such which was the curse, but the labouriousness of it. ${ }^{58}$

The classical Christian doctrine, grounded in Biblical teachings about work, and the teachings of the early church, affirmed the value and goodness of work, but did not see work as rewarding, noble, or satisfying; instead work was perceived as having a spiritual significance in that it contributed to Christian resignation. Augustine, for example, distinguished between the "active life"(vita activa) and the "contemplative life" (vita contemplativa), and while admitting the active life, which included almost every kind of work, was good and necessary, he claimed the contemplative was the better. ${ }^{59}$ The one is loved, the other endured, he stated. ${ }^{60}$

It was not until the thirteenth century that a Christian theologian again seriously examined the place of work. The theology of Thomas Aquinas is important because it provides the back drop to the development of Reformation conceptions regarding work and economic rationalisation, and therefore grants an understanding of the work ideology Luther and Calvin were familiar with. The notion of Augustine's vita activa and vita contemplativa were still a significant component in Aquinas' thought; the former was good if it was necessary, but if one could survive without working so much the better. The contemplative life was far superior, being oriented to the eternal. ${ }^{61}$

\footnotetext{
${ }^{58}$ Marshall Paul, Vocation, Work, and Jobs, in Marshall, Paul, (et al), Labour of Love; Essays on Work, p. 2

59 ibid, p. 7

${ }^{60}$ ibid, citing Augustine

${ }^{61}$ Marshall, P., p. 8
} 
Aquinas however, also pointed to the belief that each person had a place in God's creation which reflected divine will. ${ }^{62}$ In light of this he constructed a hierarchy of occupations that demonstrated what was naturally just, ${ }^{63}$ with the priesthood at the top, and the trade of merchants and shopkeepers at the bottom. The only true Christian calling was a to a monastic or priestly life; the idea of a calling to any other occupation was not even considered, for as long as each member of society did the task allotted to him or her, there was harmony in the social system, and the framework of the Christian commonwealth was secure. Work became accepted as a meritorious necessity as a result, but was understood to be ordered so by God according to a natural cycle. ${ }^{64}$

While the Catholic church developed a new doctrine of the importance of work as a consequence of Aquinas' teachings, work was still seen as a means of spiritual redemption, and was not to be measured in economic terms. ${ }^{65}$ A deep rooted suspicion of economic motives meant that in the medieval church there was no place for economic activity unless it was associated with a moral conclusion. ${ }^{66}$ As R. H. Tawney pointed out, the medieval writers had two fundamental assumptions:-

...that economic interests are subordinate to the real business of life, which is salvation, and that economic conduct is one aspect of personal conduct upon which, as on other parts of it, the rules of morality are binding. ${ }^{67}$

\footnotetext{
${ }^{62}$ Rose, p. 28

63 ibid

${ }^{64}$ Anthony, P. D., The Ideology of Work, p. 37

${ }^{65}$ ibid

66 Tawney, p. 44

67 ibid, pp. 43-4
} 
Furthermore, he says: -

At every turn, therefore, there are limits, restrictions, warnings against allowing economic interests to interfere with serious affairs. It is right for a man to seek such wealth as is necessary for a livelihood in his station. To seek more is not enterprise, but avarice, and avarice is a deadly sin. Trade is legitimate... But it is a dangerous business. A man must be sure that he carries it on for the public benefit, and that the profits which he takes are no more than the wages of his labour. ${ }^{68}$

It is clear that Weber thought that for the transcendence of economic man ${ }^{69}$ to occur, there needed to be a drastic shift in such outlook and beliefs. If Weber's theory is to be believed, this happened with the Reformation. But was it a change in the economic model, or a process of social transformation which lead to the modification of the work ideology resulting in Weber's tenet of the Protestant Ethic? The suggestion is that the upsurge in trade during the sixteenth century with the discovery of new trade routes, coupled with the break down of old social norms, was likely to have been more responsible for any change in economic and work ethics, than religious teachings. ${ }^{70}$ Undoubtedly though, it needs to be acknowledged that some change of emphasis did take place in the sixteenth and seventeenth centuries regarding both business and work ethics - a restyling of traditional norms that reflected the changing spirit of the times, but which was not restricted to Protestants. ${ }^{71}$ Robertson, who is one of Weber's sternest critics, claims that the Catholics, every bit as much as the Reformation Protestants,

${ }^{68}$ ibid, p. 44

${ }^{69}$ Anthony, p. 37

${ }^{70}$ See for example, Tawney, p. 79; Robertson, H. M., Aspects of the Rise of the Economic Individualism, p. 206; McCormack, Thelma, The Protestant ethic and the spirit of capitalism, British Journal of Sociology, vol. 20, 1969, pp. 269-70

${ }^{71}$ Robertson, p. 32, indicates that the same change of emphasis took place among the Catholics. 
encouraged industry, thrift, order and honesty.... and favoured enterprise, freedom of speculation and the expansion of trade as a social benefit. ${ }^{72}$

A second important issue in the debate surrounding Weber's thesis, concerns his interpretation of Reformation dogma pertaining to the notion of vocation or "calling." According to Weber, it was Luther who developed the concept of calling, deriving his

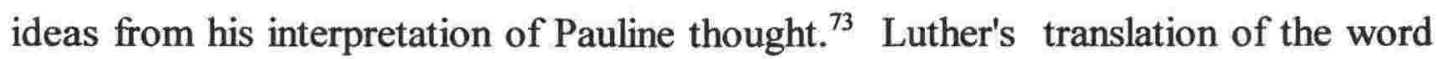
"calling" in the Pauline texts as Beruf, is seen as significant because by using this word he gave the concept of calling a distinctive new meaning. Weber makes this the basis of his entire thesis, as, if he is to believed, Luther's unique meaning of calling, was rapidly disseminated throughout the Protestant communities ${ }^{74}$ and became a fundamental doctrine. Despite Weber's lengthy notes on the word Beruf, ${ }^{75}$ in his critique of Weber's work, Hamilton argues that it seems possible that Weber may have been mistaken in his

72 ibid, p. 164. Similarly, Weber's claims that the Catholic states showed a lesser degree of economic rationalism than the Protestant ones, are discarded by Tawney, who points out that Catholic Flanders, Italy, Spain and Portugal all showed highly successful commercial achievements before the Reformation, and went on to thrive economically in the sixteenth and seventeenth centuries. (See Tawney, p. 93; and Note 32, p. 312) In his critique of Weber, Hamilton argues that Weber's opening statements in The Protestant Ethic regarding occupational and educational differences between Catholics and Protestants are based on figures provided by one of his students, Martin Offenbacher, which are incorrect. Not only that, Weber misinterprets Offenbacher's explanations, and in doing so changed conjecture into confirmed conclusions. No where, according to Hamilton, does Weber prove that there was a significant difference in outlook between Catholics and Protestants. (See Hamilton, pp. 38-43; p.84)

73 Weber, (1985), p. 83

74 Hamilton, p. 65

75 See Weber (1985), notes 1,2, and 3, pp. 204 - 212 
definition of calling as a God-given task. ${ }^{76}$ It appears that Weber overlooked alternative meanings, perhaps using the one which most suited his argument, rather than reviewing other interpretations attributed to occupational terms with similar meanings to Beruf..$^{77}$

Regardless of Luther's original meaning, Weber claims that: -

...at least one thing was unquestionably new: the valuation of the fulfilment of duty in worldly affairs as the highest form which the moral activity of the individual could assume. This it was which inevitably gave every day worldly activity a religious significance, and which first created the conception of a calling in this sense. ${ }^{78}$

While conceding that Luther initially adhered to medieval tradition, Weber asserted, in one of his numerous notes, that the difference between Protestant and Thomistic ideas of calling is so marked it can be dismissed in this context ${ }^{79}$ - hence his conviction that Luther's understanding of calling was original. However, he nevertheless acknowledged that: -

certain suggestions of the positive valuation of routine activity in the world, which is contained in this conception of the calling, had already existed in the Middle Ages, and even in late Hellenistic antiquity. ${ }^{80}$

This apparent confusion is further compounded by an earlier statement in which Weber seems to contradict himself again. He writes: -

\footnotetext{
${ }^{76}$ Hamilton, pp. 65-6

${ }^{77}$ ibid, p. 65

78 Weber, (1985), p. 80

79 ibid, note 5, p. 211

80 ibid, p. 80.
} 
it appears that neither the predominantly Catholic peoples nor those of classical antiquity have possessed any expression of similar connotation for what we know as a calling (in the sense of a life-task, a definite field in which to work), while one has existed for all predominantly Protestant peoples. ${ }^{81}$

The primary question which needs to be asked at this point, is whether the earlier teaching of Thomas Aquinas really was so different from that advocated by Luther? Was Weber correct in dismissing earlier concepts of calling, and the medieval perception of an ordered life, determined by God, as being essentially disparate from Luther's? Robertson is quite clear that Aquinas' ideas were not so dissimilar to the perceptions about calling which eventually emerged from Luther's doctrine in the sixteenth and seventeenth centuries. ${ }^{82}$ Although Luther came to reject the separation of the secular and the sacred ${ }^{83}$ and came to increasingly value work in the world, he still believed Aquinas' teaching concerning a division of people into different occupations through the ordinance of God. ${ }^{84}$ Both Aquinas and Luther considered that natural causes equip people for their particular station in life, providing different aptitudes for different occupations. ${ }^{85}$ The fundamental difference in their thought was the concept that a calling was limited to those in the religious life, as Luther, according to Weber and

\footnotetext{
${ }^{81}$ ibid, p. 79

${ }^{82}$ Robertson, p. 7

${ }^{83}$ Ballard, Paul H., (1982), Towards a Contemporary Theology of Work, p. 18

${ }^{84}$ Robertson, citing Aquinas, p. 6; Weber, (1985), p. 85

${ }^{85}$ Robertson, ibid; Marshall, G., (1982), p. 72
} 
others, radically incorporated the idea of calling into the very heart of Christian ethics, ${ }^{86}$ removing it from the domain of monasticism and the priesthood. In Ballard's words, each worldly function was given a dignity and obligation by God as the sphere of service to God and neighbour. ${ }^{87}$

Work thus became a duty in Reformation thought. Individuals were expected to labour in whatever station in life divine providence had placed them. Initially, work in one's calling was seen firstly, as an obligation to serve God, and secondly, to provide for oneself, one's family and the community, but not beyond what was needed for one's daily bread $^{88}$ Each strata of society was expected to live within its own class, and its members to sustain the social standards of that class, as it was against the laws of nature for individuals to stray from their divinely commissioned place in society. ${ }^{89}$ Those who chose not to work - able-bodied beggars, vagrants, idle monks, and those with inherited wealth - were regarded as a contradiction to this law of nature..$^{90}$

But, the eyes of Luther were in the past, ${ }^{91}$ and his acceptance of medieval economic and social ethics in the light of the changes occurring in the Reformation world, signified the

86 Weber, (1985), p. 80; Troeltsch, Ernst, The Social Teachings of the Christian Churches, p. 558; Marshall G., (1982), p. 71

${ }^{87}$ Ballard, (1982), p. 18

${ }^{88}$ Marshall G., (1982), p. 72

${ }^{89}$ Troeltsch, p. 555

90 ibid. Tawney also points to Luther's condemnation of those who deny the natural order of society, and the idle (pp. 101-2)

${ }^{91}$ Tawney, p. 103 
end of an era. While Luther may have indeed begun the movement toward a new understanding, it was John Calvin (the Swiss reformer), and the later Calvinists, who took the doctrine of calling and modified it to fit a new commercial world in which innovative economic forces were at work. Weber's interpretation of this influence of Calvinism is of vital significance to his argument for a Protestant Ethic, and has perhaps motivated the most discussion as accusations of theological misunderstanding and misinterpretation have been levelled at Weber over the decades.

In Weber's defence it must be said from the outset, that he made it clear that he had no intention of discussing the personal views of Calvin, and that the Calvinism to which he referred, was that of the sixteenth and seventeenth centuries, a fully evolved dogma. ${ }^{92}$ Nevertheless, his critics have taken him to task on this point, because as Robertson claims: -

...owing to his unhistorical treatment he has not noticed the change in the conception of the "calling" from an antidote against covetous ambition to a comfortable doctrine suitable for a commercial people. ${ }^{93}$

In his Institutes of the Christian Religion for example, Calvin wrote: -

the Lord enjoins every one of us, in all the actions of life, to have respect to our own calling. He knows the boiling restlessness of the human mind, the fickleness with which it is borne hither and thither, its eagerness to hold opposites at one time in its grasp, its ambition. Therefore, lest all things should be thrown into confusion by our folly and rashness, he has assigned distinct duties to each in the different modes of life. And that no one may presume to overstep his proper limits, he has distinguished the different modes of life by the

${ }^{92}$ Weber, (1985), note 8, p. 220

93 Robertson, p. 15 
name calling. Every man's mode of life, therefore, is a kind of station assigned him by the Lord, that he may not be always driven about at random. ${ }^{94}$

A later Puritan divine quoted by Tawney wrote: -

God doth call every man and woman...to serve him in some peculiar employment in this world, both for their own and the common good. ${ }^{95}$

In contrast to Calvin's belief ${ }^{96}$ that the individual is expected to stay in his or her station, Tawney goes on to cite later divines who anticipated that the individual would chose his or her calling, admittedly with Divine guidance and careful consideration, but nonetheless with the belief that this was God's expectation. ${ }^{97}$

From being a doctrine not dissimilar to Luther's, and therefore similar to the Thomistic teachings on calling, it has been argued that Calvin's observations on the subject were manipulated by the later Calvinist divines, to encourage and assimilate a capitalistic system. $^{98}$ It is clear that Weber's disregard for the progression of thought in Calvinist circles reduces possible alternative interpretations concerning the importance of calling in the historical context he was examining. His neglect of Calvin's original thought means he has not understood the qualifications Calvin placed around the use of earthly

94 Calvin, John, Institutes of the Christian Religion (Vol.2), p. 34

95 Tawney, p. 239

96 Calvin, p. 35

97 Tawney, p. 240

98 Troeltsch, p. 645. This raises the question of whether the doctrine of calling was modified to incorporate a spirit of capitalism, or whether the notion of calling led to the advent of the spirit. Robertson discusses this issue. (p. 27) 
blessings, ${ }^{99}$ the restrictions he set on excessive indulgence or austerity, ${ }^{100}$ or the position of callings within this doctrine. Instead, by going directly to the fully evolved dogma of the later Calvinist divines, Weber presented a picture of a doctrine which provided an ethical justification for profit-making, ${ }^{101}$ and restless, continuous, systematic work in a worldly calling... as evident proof of rebirth and genuine faith. ${ }^{102}$

According to Weber's thesis there were two distinctive features of Calvinist dogma which impacted upon the notion of calling. One was the transcendence of God, and the other was the doctrine of predestination. Returning to the writings of Calvin we read: -

By predestination we mean the external decree of God, by which he determined with himself whatever he wished to happen with regard to every man. All are not created on equal terms, but some are preordained to eternal life, others to eternal damnation... ${ }^{103}$

God's judgement Calvin admits, is unfathomable, as the damned can never change their predicament, but: -

In regard to the elect, we regard calling as the evidence of election, and justification as another symbol of its manifestation, while it is fully accomplished by the attainment of glory. ${ }^{104}$

Weber claims that the Calvinists must have inevitably asked the question Am I one of the

99 Calvin, pp. 31-35

100 ibid, p. 34

101 Weber, (1985), p. 162

102 ibid, p. 172

${ }^{103}$ Calvin, p. 206

104 ibid, p. 211 
elect $?^{105}$ and that the psychological effect, if the answer was positive, must have been extraordinarily powerful. ${ }^{106}$ Consequently, in Weber's view, the only way the Calvinist could gain some assurance of his or her election, and relieve the anxiety of uncertainty was to maintain what Gianfranco Poggi describes as a correct ethical orientation to his calling. ${ }^{107}$ This involves the duty of believing that one is chosen, because to do less is a sign of insufficient faith. The best way of attaining this certainty was to engage in intense worldly activity, ${ }^{108}$ and work accordingly became a religious duty. ${ }^{109}$

While Weber makes the claim that: -

the whole ascetic literature of almost all denominations is saturated with the idea that faithful labour..... is highly pleasing to God..... [ and provides] the psychological sanction of it through the conception of this labour as a calling, as the best, often in the last analysis the only means of attaining certainty of grace, ${ }^{110}$

it has been pointed out that nowhere in The Protestant Ethic, does he attempt to document his supposition. The suggestion has been made that a search of biographies and personal documents from the sixteenth and seventeenth centuries may have indicated whether an urgent anxiety over their fate in the after-life actually drove into

105 Weber, (1985), p. 110

106 ibid, p. 128

107 Poggi, p. 66

108 Weber, (1985), p. 112

109 Troeltsch, p. 645, claims that the conception of calling, " laid the foundation of a world of specialized labour, which taught men to work for work's sake."

${ }^{110}$ ibid, p. 178 
entrepreneurship ${ }^{\prime}$ particularly devout and sensitive Calvinists, ${ }^{111}$ but Weber made no effort to do this. ${ }^{112}$ To assume from such a distance in time that this anxiety over the after-life was a major concern for the general population, without providing any real evidence, is a significant weakness in Weber's theory. ${ }^{113}$

Alongside the concepts of calling and predestination, and the accompanying anxiety, Weber suggested that an indication of election was the acquiring of wealth. Although the pursuit of wealth was considered reprehensible if it was simply an end in itself the attainment of it as a fruit of one's labour in a calling was a sign of God's blessing. ${ }^{114}$ Weber was not alone in contending this, and despite argument to the contrary, this belief has popularly become part of the philosophy behind the Protestant work ethic. Troeltsch, for example in the second volume of his book, The Social Teaching of the Christian Churches, categorically states, Profit is the sign of the blessing of God on the faithful exercise of one's calling. ${ }^{115}$ He does, admittedly, caution that labour and profit

111 Poggi, p. 81

112 Unless you count his use of Benjamin Franklin's writings. Viner (p. 156) and Poggi (p. 81) both make this point regarding Weber's lack of use of contemporary secular writings to test his theory.

113 Poggi, p. 81. Marshall, G., (1982) also questions Weber's lack of independent evidence as to the motives, economic beliefs, and world view of modern capitalists.

(p. 113). Hamilton observes that a serious difficulty in Weber's argument about psychological sanctions is the fact that very little information exists about the psychological state of Calvinists and others in this period. (p. 71) Viner queries whether Weber was attributing to the" rank and file" Calvinist, doctrines only expounded by theologians. (p. 153)

114 Weber, (1985), p. 172

115 Troeltsch, p. 648 
were never intended for purely personal interest, ${ }^{116}$ qualifying this by reminding the reader that profit should be used for the good of the community, and that the individual should only retain what he requires for his own needs. Likewise Tawney affirmed that Calvinist moralists indicated that practical success is at once the sign and the reward of ethical superiority. ${ }^{117}$

Evidence for this stance is meagre according to the critics. Weber has theorized that Calvinists must have made such an assumption as a consequence of their psychological angst, but he once again provides little evidence. ${ }^{118}$ There may be some sparse support for Weber's viewpoint found in English writings ${ }^{119}$ but generally such an interpretation completely subverted the fundamental theological structure of Calvinism, ${ }^{120}$ as Weber (and his supporters) ignored the wider context of calling, and the preoccupation with the transcendence of God. By focusing on "calling" as being little more than the equivalent of an "occupation", they overlooked the broader framework of the doctrine which converged on service to God being the only deserving end of all undertakings. Materialistic reward for serving in one's calling was not part of the true Calvinist doctrine. Rather, Calvin declared: -

When believers ...feel their faith strengthened by a consciousness of integrity, and entertain sentiments of exultation, it is just because the fruits of their calling convince them that the Lord has admitted them to a place among his

116 ibid

117 Tawney, p. 264

${ }^{118}$ Hudson, in Green (ed), p. 58; Hamilton, p. 74

119 Hamilton ( p. 75) cites John T. McNeill to demonstrate this point.

${ }^{120}$ Hudson, in Green (ed), p. 58 
children. $^{121}$

A further faulty aspect of Weber's theory of the notion of worldly success in a calling being an indication of divine election, is, according to the critics, his disregard of the antipathy towards wealth in Calvinist teaching. ${ }^{122}$ Having chosen not to utilise the theological treatises on dogma and ethics to draw out the Protestant position on economic behaviour and attitudes, Weber went instead to the pastoral writing of the seventeenth century Puritans such as Richard Baxter. ${ }^{123}$ His selective use of this material, and the way he tailored it to fit his thesis, ${ }^{124}$ has resulted in much being written concerning his misinterpretation of the literature he chose to review. ${ }^{125}$

In the face of the criticism of not taking seriously the aversion to wealth demonstrated in the Calvinist literature, Weber responded with what Malcom MacKinnon calls the

121 Calvin, p. 87

122 Keating, M. C. P., Clerics and Capitalists. A Critique of Weber's Protestant Ethic Thesis, p. 18; Hudson, in Green (ed), p. 59

123 Viner, p. 155

124 Hamilton in his discussion about Weber's work is critical of the way he also used Benjamin Franklin's autobiography, claiming that Weber "selected some elements that supported his position and neglected those that would challenge his claims." (p. 54) Viner also suggests that Weber manipulated the sources he used through implication or insinuation to fit his thesis. (p. 153) Keating is quite clear that Weber tailored his account to fit. (p. 15)

${ }^{125}$ For example Samuelsson, Viner, Keating, Hudson, and MacKinnon to name a few, all examine Weber's interpretation of the material used. 
notion of unintendedness. ${ }^{126}$ While acknowledging the antimammonism of the pastoral teachings, Weber nevertheless attempted to prove that ascetic Protestantism gave rise to a spirit of capitalism which led to the emergence of economic rationalism. The very theology of predestination and calling by Weber's reckoning, unintentionally provided the psychological sanction for accumulation of wealth. He ignores the fact that there is not a word in Baxter that urges the pursuit of private profit as a way of earning favour from God. ${ }^{127}$ The reality is that Baxter believed it was the devil, not God, who

is exceeding diligent to get the wealth and prosperity of the world on his side that he may not seem to flatter his servants with empty promises but to reward them with real felicity and wealth. ${ }^{128}$

Baxter it is said, indicated that the person who makes earning a profit his or her end goal, denies the end of their calling. ${ }^{129}$ Weber however, placed limits on the hostility towards wealth seeking, and argued that it was only wealth sought for self-indulgence which was condemned. ${ }^{130}$

In light of the criticisms levelled against Weber's theory of a Protestant work ethic it could seem that conceivably it is more of a mythological abstraction than a concept grounded in reality. In his study Clerics and Capitalists, M. C. P. Keating suggests that

\footnotetext{
${ }^{126}$ MacKinnon, in Lehmann and Roth (eds), p. 216; also MacKinnon, Malcom H., Part II: Weber's exploration of Calvinism: the undiscovered provenance of capitalism, The British Journal of Sociology, Vol. XXXIX, Number 2, 1988, p. 188

${ }^{127}$ MacKinnon, in Lehmann and Roth (eds), p. 221

${ }^{128}$ Hudson, in Green (ed), citing Richard Baxter, p. 59

129 ibid

${ }^{130}$ Keating, p. 8
} 
Weber's theoretical conclusion can be tested by constructing a careful record of the life model recommended by the Calvinist divines, and then comparing this with the actual behaviour of the lay people. ${ }^{131}$ It is obviously not in the scope of this chapter to replicate Keating's work, but in trying to determine the validity or errancy of the hypothesis of a Protestant work ethic, it may be helpful to briefly consider the teaching of the Calvinist divines of the era examined by Weber. ${ }^{132}$

Keating himself admits that there is no disputing Weber's claims that the clergy extolled the virtues of vocational toil and waste avoidance. ${ }^{133}$ The habits of diligence and thrift were also sought, but wealth was renounced because it detracted from the highest duty of humankind, service to God and humanity. Baxter is cited as saying: -

Be wholly taken up in diligent business of your lawful callings when you are not exercised in the more immediate service of God...Labour hard in your calling. ${ }^{134}$

You are not to labour to be rich for the purposes of fleshly indulgence, but for God's sake. ${ }^{135}$

Choose the employment or calling...in which you may be the most serviceable to God. Choose not that in which you may be the most honourable in the world; but that which you may do the most good and best escape sinning. ${ }^{136}$

131 ibid, p. 14

132 As will be shown in the next chapter of this thesis, a work ideology was transmitted from this period through to the 1800 s. The origin of what is known as the Victorian work ethic, appears to have been derived from Puritan teachings.

${ }^{133}$ Keating, p. 32

${ }^{134}$ Fullerton, Kemper, Calvinism and Capitalism: An Explanation of the Weber Thesis, in Green (ed), p. 17

135 ibid

${ }^{136}$ MacKinnon, in Lehmann and Roth (eds), p. 222 
Above all, God and Mammon cannot be reconciled. ${ }^{137}$

Many examples of similar statements by Calvinist teachers such as Perkins, Ames, and others, are presented by critics of Weber in their attempts to demonstrate that he misused the material available, ${ }^{138}$ all pointing to the fact that while hard work was exhorted, there was a considerable wariness of affluence and the temptations of this world. ${ }^{139}$

Idleness and relaxation were also an issue for the Calvinist divines, who perceived them as manifestations of human selfishness which served neither God nor humankind. ${ }^{140}$ Keating maintains that clergy opposed all attempts to earn profits on the basis that far from enjoying their wealth and distributing it for the needs of the present, some individuals would become so involved in money making activities they would ignore God and their spiritual duties altogether. These concerns, Keating claims, went well beyond a mere worry about the dangers of relaxation and idleness. ${ }^{141}$ It was far more important to lay up treasures in heaven than on earth, ${ }^{142}$ and economic ambition which permitted the sins of idleness and luxury, hardly allowed for that.

137 ibid

${ }^{138}$ MacKinnon, (1988), p. 196-7, cites Perkins and Ames; Keating, p. 20-4, cites Perkins, Preston, and Baxter, and mentions Bolton, and Greenham. All the citations are similar in content to the ones quoted in the main text above.

139 Samuelsson, p. 79

${ }^{140}$ Keating, p. 19

141 ibid.

142 ibid, p. 27 
The ethical precepts preached by the divines however, do not seem to have made much impression on the laity. Certainly lay people worked hard, and even appear to have taken the teachings about wasteful pleasure seriously, but they rejected any prohibition on the accruement of wealth. ${ }^{143}$ Keating surmises: -

The divines sought to form a particular type of character - a decent, hardworking other serving character, which eschewed self-interest, covetousness and private gain seeking in the interest of community service through vocational activity - and they failed miserably in their project. ${ }^{144}$

Nevertheless, the virtues of industry, diligence and thrift continued to be preached despite the teachings regarding economic ambition being ignored. It is these values which were passed on to later generations. ${ }^{145}$

In the final analysis, the validity of Weber's Protestant ethic, depends on an important question voiced by Samuelsson: -

Was Puritanism's recorded attitude to diligence, thrift, and free interest rates something unique to this form of religion, or did it merely reflect patterns of thought generally accepted by the age? ${ }^{146}$

There are two alternative responses to this question. Firstly, the suggestion has been

143 ibid, p. 40.

144 ibid, p. 38

${ }^{145}$ The emphasis by seventeenth century Calvinists on industry versus idleness, also had another aspect to it - a resulting attitude towards the poor and unemployed that has to some extent continued to this day. Tawney declared in his study of the period that the austerity of the Puritan moralists motivated an antagonism to those seen as "idle" which led to legislation in England in 1649, that offered beggars the choice of work or a whipping. He observed, "A society which reverences the attainment of riches as the supreme felicity will naturally be disposed to regard the poor as damned in the next world, if only to justify itself for making their life a hell in this. "(p. 265)

146 Samuelsson, p. 80 
made by Guy Oakes that even if Weber did misinterpret or misuse the Calvinist pastoral writings, there is still the possibility of a connection between the Protestant work ethic and the spirit of capitalism. ${ }^{147}$ The important issue is, according to Oakes, whether the ethos of inner-worldly asceticism was incorporated into the lives of religious nonprofessionals. ${ }^{148}$ As Keating has demonstrated, this appears unlikely. This would lead to the conclusion that what has become known as the Protestant ethic therefore came out of the thought patterns of the era, rather than the theology. This second response is the most plausible if it is accepted that the churches, Protestant and Catholic alike, accommodated themselves to the mind set and spirit which went with the commercial development of the sixteenth and seventeenth centuries. ${ }^{149}$ In other words, the churches adapted themselves to their environment, and the clergy preached what they knew their parishioners wanted to hear. ${ }^{150}$ Christopher Hill is cited as saying: -

The protestant revolt melted down the iron ideological framework which held society in its ancient mould. Where capitalism already existed, it had henceforth freer scope. But men did not become capitalists because they were protestants, nor protestants because they were capitalists. In a society already becoming capitalist, protestantism facilitated the triumph of new values. There was no inherent theological reason for the protestant emphasis on frugality, hard work, accumulation; but that emphasis was a natural consequence of the religion of the heart in a society where capitalist industry was developing. It was, if we like, a rationalization; but it flowed naturally from protestant theology, whose main significance.... is that in any given society it enabled religion to be moulded by those who dominated in that society. ${ }^{151}$

147 Oakes, in Lehmann and Roth (eds),pp. 292-3

148 ibid, p. 291

149 Robertson, p. 165, suggests that the churches "assimilated" the spirit of capitalism, rather than the spirit coming out of the ethics of the church.

${ }^{150}$ Marshall G., (1982), p. 148

151 ibid, citing Hill, p. 145 
Although Weber's reasoning for what he perceived as the development of a Protestant ethic has been shown to be faulty by many scholars, it can be demonstrated that the substance of the work ethic was nevertheless real. Industry, thrift and the stock piling of money, were undoubtedly virtues valued by Protestants and Catholics alike, that became part of the European world view.

Remembering that Weber's attempt to understand the reality of his time was to draw parallels between the past and the present, and to specify what is continuous and discontinuous between various cultural epochs, ${ }^{152}$ is it feasible to do the same thing in the late twentieth century? Given a conviction that a work ethic (albeit not necessarily a Protestant one), is a reality, is it reasonable to examine the existence of such an ethic in contemporary society? Attempts by sociologists in the USA, especially in the 1960s, to test Weber's thesis against contemporary American society have tended to be dismissed as irrelevant. ${ }^{153}$ Criticism has been levelled about the quality of the research, and against hypotheses that are described as poor reflections of Weber's argument. ${ }^{154}$ Much of the research for example, appears to have been aimed at examining the differences of occupational achievement between modern day Protestants and Catholics, ${ }^{155}$ thereby concentrating on only a portion of Weber's hypothesis. The

${ }^{152}$ Chalcroft, in Jay and Reed (eds), p. 17

${ }^{153}$ Greely, Andrew, The Protestant Ethic, Sociological Analysis, Vo. 25, 1964, p. 20; Bouma, Beyond Lenski: A Critical review of Recent "Protestant Ethic" Research, Journal for the Scientific Study of Religion, Vol.12, 1973, p. 141; Wagner, Helmut, The Protestant Ethic: A Mid-Twentieth Century View, Sociological Analysis, Vol. 25, 1964 , p. 37

154 Bouma, p. 153

155 For example, Wagner (1964); Lenski (1961) 
secularization of the "Protestant" ethic has been largely ignored, and the evaluation of actual specific beliefs and values has been generally neglected. ${ }^{156}$

Finally, the historical perspective, so important in Weber's methodology, has been virtually nonexistent in the American investigations. Wagner in his article The Protestant Ethic: A Mid-Twentieth Century View, writes: -

Most of the studies, of necessity, lack the crucial, that is, historical point of reference. Snap-shot techniques reveal little if they cannot be compared to snap shots taken one, two, or three generations ago....To our understanding, the whole problem becomes socially meaningful only in historical perspective, and gains sociological significance only as a study of long-range trends. ${ }^{157}$

Any study of the work ethic in contemporary New Zealand therefore needs to be placed within an historical framework which provides those "snap shots". We will start then with an examination of the Victorian work ethic, the cornerstone of a New Zealand ideology of work.

156 Kim, Hei C., The Relationship of the Protestant Ethic Beliefs and values to Achievement, Journal for Scientific Study of Religion, 16(3), 1977, p. 261

157 Wagner, p. 37 


\section{CHAPTER 2}

\section{"Know thy work and do it" - the new Gospel ${ }^{1}$}

The work values of nineteenth century Victorian Great Britain sailed to New Zealand, with the emigrants who were to settle the new colony, as part of a mind set which was to characterise the psyche of New Zealanders for several generations. Cloaked in middle class respectability, the understanding that work was noble, even sacred, ${ }^{2}$ and therefore a moral imperative, was endorsed by the culture the British settlers were leaving behind. From a newly industrialised society, in which the word "work" was said to be the most popular word except God, ${ }^{3}$ the immigrants came to a primarily undeveloped colony where the majority not only expected to work hard, but also were not afraid to do so.

This Victorian Gospel of Work ${ }^{4}$ which is said to have permeated the belief system of the people of nineteenth century Great Britain (and was therefore, in all probability, assimilated into the ideology of work brought to colonial New Zealand), was largely the consequence of a period of rapid economic and social transformation as a result of the industrial revolution, beginning in the mid-eighteenth century. Much more than just an

${ }^{1}$ Carlyle, Thomas, Past and Present, p. 177

2 ibid

${ }^{3}$ Houghton, Walter, E., The Victorian Frame of Mind 1830-1870, p. 242

${ }^{4}$ Briggs, Asa, Victorian People. Some Reassessments of People, Institutions, Ideas and Events 1851-1867, pp.125-6, and Houghton, p. 251, both use the term, but it appears to have originated from the statement in Carlyle's Past and Present:- The latest Gospel is: Know they work and do it. (p. 177) 
expansion of commerce, technology, or economic growth, the industrial revolution was a revolution in terms of commitment to work. The factory age demanded a new pattern of work, one based not only on new standards of diligence because of technical reasons, ${ }^{5}$ but also on the discipline of a regular and reliable ${ }^{6}$ work force. Gone were the days of "Saint Monday", when workers absented themselves from the workplace on a Monday to recover from the intemperance of the weekend ${ }^{7}$. No longer could British labourers work until their purses were full, then be idle until the money was gone. ${ }^{8}$

Accompanying this emergence of new attitudes to work was the erosion of the customary perquisites (such as gleaning, collecting wood, or keeping a few stock)which had once enabled the British labourer to raise their standard of living through a nonwaged economy. 9 This decline in traditional privileges that had supplemented the income of the labourer, and the decline of semi-independent cottagers into dependent agricultural labourers, helped draw workers into a factory system where the lure of steady and higher wages led to transformed work habits. The older semi-rural work pattern was unsuited to the needs of the factory age ${ }^{10}$ making it necessary for the industrial entrepreneurs to enforce a new discipline of work involving punctuality,

5 Daunton, M. J., Progress and Poverty. An Economic and Social History of Britain 1700-1850, p. 178

${ }^{6}$ Harrison, J. F. C., (1971), The Early Victorians 1832-1851, p. 135

${ }^{7}$ ibid

${ }^{8}$ Daunton, p. 177

9 ibid, p. 179

${ }^{10}$ Harrison, p. 135 
regular attendance, and a steady application to production. ${ }^{11}$ One writer observes: Andrew Ure in 1835 commented that the main difficulty of the pioneer factory master, Richard Arkwright, was not in developing a powered spinning-machine; it was above all, in training human beings to renounce their desultory habits of work.... ${ }^{12}$

What has become recognised as a Victorian work ethic then, was an evolution of a new and positive set of attitudes regarding work, in response to change. ${ }^{13}$

The attraction of regular and higher wages that enticed workers into the factory system, resulting in the movement of work from home to the factory, led however, not only to new attitudes to work, but also to a new level of consumption. Harold Perkin points out that consumer demand was the ultimate economic key to the Industrial Revolution... ${ }^{14}$ as men and women were prepared to work long, hard hours, in order to gain access to the goods which industrialisation was producing. ${ }^{15}$ As workers became incorporated into a market economy based on the production of consumer goods and spending, the separation between household and working place became increasingly pronounced, and the meaning of work changed from the ethos of mutuality and moral

${ }^{11}$ Perkin, Harold, The Origins of Modern English Society, p. 113

12 Daunton, p.177

13 Travers, Tim, Samuel Smiles and the Victorian Work Ethic, p. 340

${ }^{14}$ Perkin, p. 91

15 ibid. Houghton also refers to the way the existence of hundreds of widely available new objects drove people to increase their work load so as to be able to afford the articles they desired. (p. 6) 
imperative to the ethos of the individual and market imperatives. ${ }^{16}$ In his examination of the Victorian work ethic, Tim Travers comments: -

the 19th century can be seen as the battleground in which a traditional belief in work as a value in itself, and as a means of both forming and judging internal character or "identity", was defeated both by the concept of work as a measurable commodity...., and by the utility of work as an amoral and secular route to social mobility and financial success. ${ }^{17}$

However, it needs to be acknowledged that many attitudes and ways of thinking about work attributed to the Victorians actually originated in the late eighteenth century, several decades before the accession of Queen Victoria to the throne in 1837. The philosophy of writers like Adam Smith, Thomas Malthus, and David Ricardo undoubtedly coloured that of the Victorians, especially as they struggled on Travers' "battleground" to come to terms with the rapid economic development of the era (and its accompanying recessions), the incredible rise in population growth, ${ }^{18}$ and the transformation of social status and consciousness. As Harrison puts it: -

It is hard to escape the impression that very large numbers of people in the 1840 s were completely bewildered by the environment in which they found themselves. They were required to make adjustments of a far reaching nature: moving to a strange new place, starting a new type of job, suddenly being unemployed. Their past experience had given them few of the social skills required to cope with such situations. ${ }^{19}$

16 Berg, Maxine, Women's Work, Mechanisation and the early phases of industrialisation in England, in Joyce, Patrick, (ed), The Historical Meanings of Work, p. 64

17 Travers, p. 1

${ }^{18}$ Perkin, p. 4. The population more than trebled during the nineteenth century.

19 Harrison, p. 12 
The significant writings that were in response to the first rash of industrialisation were therefore seized upon by Victorians trying to come to terms with this new environment.

The laissez faire economic philosophy of Adam Smith, ${ }^{20}$ for example, attracted the early Victorians on the premise that somehow 'nature' had arranged that the prosperity of the individual...would automatically result in the public good. ${ }^{21}$ Smith's contentions that economic motivation is centred on self-interest, ${ }^{22}$ and that even the humblest of workers would become more industrious as a consequence of high wages, ${ }^{23}$ were made to conform with classical beliefs that Divine Providence had created a system in which only those who understood the virtue of industry and thrift would succeed. ${ }^{24}$ This concept of a doctrine of "natural law" was a recurrent theme for Smith who wrote in a much quoted passage,

As every individual .....endeavours as much as he can both to employ his capital in the support of domestic industry, and so to direct that industry that its produce may be of the greatest value; every individual necessarily labours to render the annual revenue of the society as great as he can. He generally, indeed, neither intends to promote the public interest, nor knows how much he is promoting it. By preferring the support of domestic to that of foreign industry, he intends only his own security; and by directing that industry in such a matter as its produce may be of the greatest value, he intends only his own gain, and he is in this, as in many other cases, led by an invisible hand to

20 Smith published his book An Inquiry into the Nature and Causes of the Wealth of Nations in 1776 outlining his laissez faire theories of economics
${ }^{21}$ Altick, Richard D., Victorian People and Ideas, p. 129
${ }^{22}$ Galbraith, J. K., A History of Economics: the Past as the Present, p. 64; also Perkin, p. 85
${ }^{23}$ Himmelfarb, Gertrude, The Idea of Poverty, (1984), p. 62
${ }^{24}$ Altick, pp. 126-127 
promote an end which was no part of his intention. ${ }^{25}$

This belief in natural law, alongside the work of Divine Providence, is also found in the writings of Thomas Malthus in his response to the population explosion of the late eighteenth century. ${ }^{26}$ The thought of Malthus was to influence social attitudes and policies for at least half the Victorian era, ${ }^{27}$ especially his argument that, All cannot share alike the bounties of nature. ${ }^{28}$ In his defence of social inequality Malthus wrote: -

If no man could hope to rise or fear to fall in society; if industry did not bring its own reward, and indolence its punishment; we could not hope to see that animated activity in bettering our own condition which now forms the masterspring of public prosperity. ${ }^{29}$

Society, he argued, needed to accept the misery of the lower classes, their poverty and suffering, and give up trying to alleviate the problem, for it was by the design of God that such suffering should occur. According to Malthus only necessity would compel people to work, as they are born inert, sluggish, and averse from labour, ${ }^{30}$ and providing social assistance such as the Poor Laws, would remove one of the strongest

${ }^{25}$ Routh, Guy, The Origin of Economic Ideas, citing Adam Smith, p. 87

${ }^{26}$ Malthus published An Essay on the Principle of population, as it affects the Future Improvement of society.....in 1798

27 Himmelfarb (1984), p. 101

${ }^{28}$ Routh, citing Malthus, p. 110

29 Perkin, citing Malthus, p. 85

${ }^{30}$ Hilton, Boyd, The Age of Atonement. The Influence of Evangelicalism on Social and Economic Thought, citing Malthus, p. 74 
checks to idleness and dissipation. ${ }^{31}$ As Malthus revised his Essay over the next decade, his views became more even more dogmatic, until the suffering masses of the poor became sinners enduring their just and proper punishments for multiplying too fast, rather than merely being victims of some natural law. ${ }^{32}$ This concept that the suffering of the poor was their own fault, was later to be incorporated into the belief that lack of employment, or a meagre wage, was somehow always the fault of the individual. ${ }^{33}$

The issue of subsistence wages, introduced by Adam Smith and later extended by David Ricardo, also influenced Victorian thought, especially that of employers. The natural price of labour, wrote Ricardo, is that price which is necessary to enable the labourers, one with another, to subsist and perpetuate their race without increase or diminution. ${ }^{34}$ Wages tended to settle at a natural level according to Ricardo, which would provide the necessities for workers and (although this was largely ignored by employers), those conveniences become essential to him from habit. ${ }^{35}$ This Iron Law of Wages was deemed to confirm another aspect of the classical doctrine of Divine Providence, that those who worked were meant to be poor. ${ }^{36}$

${ }^{31}$ Routh, citing Malthus, p. 112

32 ibid, p.113

33 Himmelfarb (1984) points out that John Wesley had earlier denounced as wickedly devilishly false the notion that poverty was the product of idleness (p. 33) but nevertheless Malthus' teachings were attractive to those who were discomforted by the existence of poverty, and trying to find an acceptable interpretation for its being.

34 Galbraith, citing Ricardo, p. 84

35 ibid

36 ibid 
Does this recourse to an earlier Puritan tradition of Divine Providence by economists in the late eighteenth and early nineteenth centuries, in any way indicate that Weber's theories might have a bearing on understanding the Victorian work ethic? This is not to ask whether the revised Puritan thought of the mid to late eighteenth century led to the capitalist spirit of an industrial factory system, but whether the theological beliefs of the era influenced the attitude to work which became of paramount value to the Victorians? The commercial spirit was undoubtedly well entrenched in Great Britain before the industrial revolution indeed began, with society already organised on capitalist principles, with rural enterprise for example, divided between landlords, tenant farmers, and a labour force that worked for wages. ${ }^{37}$ While the primary consideration of this thesis concerns the extent to which a revised Puritan doctrine of hard work in one's station in life, and the concept of thrift and reward, was embraced by the people who were to become first generation New Zealanders, the issue of Weber's " capitalist spirit" however, does need to be briefly addressed in the light of the mind set of the Victorian industrial entrepreneurs who encouraged the transformation of work habits.

It certainly appears from the literature that the old Puritan spirit, which had been dormant for over a century, had only been slumbering. ${ }^{38}$ The Evangelical awakening of the mid-eighteenth century it is suggested, aroused this slumbering spirit and evoked anew the teachings of the seventeenth century Puritans. One writer comments that it is a cliche of Victorian history that the weekday businessman was the Sunday

37 Ward, W. R., Religion and Society in England 1790-1850, p. 9

${ }^{38}$ Newsome, David, The Victorian World Picture, p. 91 
Evangelical, ${ }^{39}$ and certainly it appears that much of the energy used in pursuing secular and commercial vocations, originated in Evangelical teachings. ${ }^{40}$ The doctrines of stewardship and mission, for example, provided a groundwork for rationalizing the pursuit of commercial success. Ian Bradley in his study on the Evangelical impact on the Victorians writes: -

The notion of stewardship, to which both puritans and Evangelicals strongly adhered, and which held that it was the individual's duty to harbour the material resources of the world and to cause them to multiply for the greater glory of God, clearly encouraged the assumption of an entrepreneurial role. Like puritanism, Evangelicalism rationalized and justified worldly success. Its teaching that everything which happened on earth was a manifestation of the workings of Providence tended to equate success with virtue.... ${ }^{41}$

Joseph Wilson, a manager at Bradford Mills, and later a mill owner in his own right, is cited as saying: -

Such riches as resulted from a successful business career I consider myself to hold in trust as God's Steward. I never had any love for money: my wants are few: I live quietly, and seek no wealth... The secret of my highest success has been simply this - that I have lived for service and not for Self..$^{42}$

Alongside, and intertwined with this concept of stewardship, was one of a sense of mission. There was an almost messianic faith in the civilising power of industry. ${ }^{43}$ The

\footnotetext{
39 Altick, p. 168

40 ibid

${ }^{41}$ Bradley, Ian, The Call to Seriousness. The Evangelical Impact on the Victorians, p. 157

42 Joyce, Patrick, Work, Society and Politics. The Culture of the Factory in Later Victorian England, (1980), p. 141

43 ibid
} 
observation was made: -

Manufacturers and workers it was often said, were engaged in a vast crusade to subdue nature for the benefit of man and thus to strengthen England and further the progress of civilization. ${ }^{44}$

How far this sense of mission extended to the workers themselves is uncertain, although Evangelical teaching instructed that on a personalised level, each individual was expected to have a sense of purpose or mission. Bishop Newman, for example, is cited as saying in an 1849 sermon: -

everyone who breathes, high and low, educated and ignorant, young and old, man and woman, has a mission, has a work. $^{45}$

Considering the Victorian compulsion to give work and machinery, a Promethean and spiritualised task ${ }^{46}$ in an attempt to bring the unnatural power of industrialisation into the parameters of intellectual understanding, it seems likely that for the entrepreneurs at least, this sense of "mission" provided an acceptable excuse for commercial expansion. Rationalizing industrialisation as a "mission", or a contribution to social progress, linked it to the will of God.

Is this recourse to theological explication for the justification of commercial and industrial development, evidence that the Victorians adopted a "Protestant ethic" which in turn led to a further advancement of the "capitalist spirit"? Certainly, the virtues of hard work, self-control and self-discipline, and thrift, were preached by nineteenth

\footnotetext{
${ }^{44}$ Houghton, p. 250

45 ibid, p. 244

46 Travers, p. 340
} 
century clergy (especially those of the nonconformist Dissenting groups), just as they had been by some of the post-Restoration Puritans. Undoubtedly, these virtues not only became internalised as part of a middle class Victorian morality, but also provided a rationale for the intense work activity that characterised the era. Generally it is agreed by historians that Evangelicalism laid the foundation for Victorian values, ${ }^{47}$ because it was from the pulpit through sermons, that public opinion was largely formed, ${ }^{48}$ but were these ideals exclusively those of Protestantism, or were they also the ideals of secular business?

One English Congregational minister, Robert Vaughan, commented in the 1840s: -

It is in the nature of religion to seize upon and consecrate the self-discipline and patterns of thought and behaviour generated by successful commerce....Industry, in place of being merely a social virtue, inculcated on the principles of human wisdom or expediency, is made to be indispensable, in the great majority of mankind, to religious consistency, and is enforced, accordingly, by the highest possible sanctions. ${ }^{49}$

It seems likely that the main features of the Puritan/Evangelical doctrine on work ${ }^{50}$

47 Bradley, p. 14; Himmelfarb, Gertrude, The De-Moralization of Society. From Victorian Virtues to Modern Values, (1995), p. 6

${ }^{48}$ Harrison (1971), p. 133; Newsome, p. 143

${ }^{49}$ Cited in Viner, pp. 178-179

${ }^{50}$ In Chapter One, I argued that the sixteenth - seventeenth century church incorporated the spirit of capitalism, rather than the spirit coming out of the ethos of the church. It is my view that the same happened in nineteenth century Britain. Gertrude Himmelfarb (1984) however, claims that the work ethic of Victorian Britain was derived far more from Puritanism than from capitalism, and that the virtues of work were deeply rooted in the culture. (p. 368) Ian Bradley also argues that it was revived Puritan values which aided the growth of business and commerce in nineteenth century Britain. (p.157) Evangelical ideas he claims, could have been deliberately designed for businessmen and financiers. ( $p$. 158) 
would have been adopted despite any religious influence based on the natural requirements of an industrial society, ${ }^{51}$ and that the Evangelicals, like the Puritans before them, tried to reenforce the concept of the sanctification of work in the light of their congregations' secular pursuits.

This apparent ready acceptance of Evangelical principles concerning work, was largely a consequence of the demands on the Victorian population in coming to terms with a rapidly changing, and progressively complex industrial society. ${ }^{52}$ Even intellectuals struggling to explain the meaning of life in an increasingly secular and agnostic society, grasped the religious grounds for intense activity and industry, and embraced the notion of work as a sacred task. The writings of Thomas Carlyle, Scottish historian and essayist, are a classic and often quoted example of this intellectual adoption of an almost supernatural justification for work. Carlyle wrote in his essay Past and Present,

...there is a perennial nobleness, and even sacredness, in Work. ${ }^{53}$

Blessed is he who has found his work; let him ask no other blessedness... Labour is Life: from the inmost heart of the worker rises his god-given Force, the sacred celestial Life-essence breathed into him by Almighty God; from his inmost heart awakens him to all nobleness, - to all knowledge, "self-knowledge" and much else, so soon as Work fitly begins. ${ }^{54}$

Work is of a religious nature:- work is of a brave nature; which it is the aim of all religion to be. ${ }^{55}$

51 Houghton, p. 247

52 Bradley, p. 33

${ }^{53}$ Carlyle, p. 176

54 ibid, p. 178

55 ibid, p. 179 
Admirable was that of the old Monks, "Laborare est Orare," Work is Worship. ${ }^{56}$ All true Work is sacred; in all true Work, were it but true hand-labour, there is something of divineness. Labour, wide as the earth, has its summit in Heaven. ${ }^{57}$

In the face of an increasing loss of Christian faith, a religion of work for many Victorians was an opportune substitute, especially when there appeared to be a supernatural framework to provide its blessing. ${ }^{58}$ The values of industry, thrift, self-denial, and diligence began to acquire a sanctity of their own, and separated from their religious roots, became secular virtues in their own right by the end of the Victorian era. ${ }^{59}$

But what was the chief motivation behind this glorification of work? Evangelical preaching aside, why was work exalted to the point that it became the "new gospel"? Put quite simply - money, success and respectability. ${ }^{60}$ Even before the beginning of the Victorian era, the English author, Robert Southey wrote,

Wealth! wealth! wealth! Praise be to the god of the nineteenth century! The golden idol! the almighty Mammon! Such are the accents of the time, such the cry of the nation.... There may be here and there an individual, who does not spend his heart in labouring for riches; but there is nothing approaching to a class of persons actuated by any other desire. ${ }^{61}$

56 ibid, p. 181

57 ibid, p. 182

58 Houghton, p. 251. Altick also suggests that work and religious faith became counterparts in a secular context. (p. 168)

59 Himmelfarb (1995), p. 7

${ }^{60}$ Houghton, p. 243

61 ibid, p. 183-4, citing Southey, from Colloquies on Society (1829) 
While the Evangelicals may have preached against the horrors of this Mammonism, nevertheless money was the primary motivation for working in all social classes, and at least one preacher recognised this when he pointed out that the poor man is not thinking of his place in the moral universe as he works, but is thinking of the next meal, of the next payday, of the next rent-day. ${ }^{62}$ The author of the tract How To get Money Quickly, Or, Thirty Ways Of making A Fortune, published in 1866, also recognised that while people talked about the dignity of work and hard labour, no one really believed it. Instead, he said, Wealth is the only aim of life - gold, the only true worship. ${ }^{63}$

This pursuit of wealth was also the pursuit of social status. ${ }^{64}$ In 1820, Malthus, in his Principals of Political Economy, had commented regarding the motivation of contemporary capitalists, Among these motives is undoubtedly the desire of advancing his rank... ${ }^{65}$ Social mobility, however, was not readily accepted by the early Victorians, despite the emulation of the higher classes by the lower ranks, and the expectations of a rapidly expanding middle class. The primary reason for this was the concept of a divinely ordained social structure that was deeply rooted in the British mind. ${ }^{66}$ The words of a hymn by Mrs C. F. Alexander, written for Victorian children, illustrate well this notion of a social structure with divine origins, in which each class is to move only

${ }^{62}$ Golby, J. M., (ed), Culture and Society in Britain, p. 122, citing Henry Liddon, from a sermon preached in 1876

${ }^{63}$ Cited in Travers, p.11. The author was not named.

${ }^{64}$ Perkin, p. 85

65 ibid, p. 89, citing Malthus

${ }^{66}$ Hart, Jenifer, Religion and Social Control in the Mid-Nineteenth Century in Donajgrodzki, A. R. (ed), Social Control in Nineteenth Century Britain, p. 108 
in its own sphere: -

The rich man in his castle,

The poor man at his gate,

God made them, high or lowly,

And ordered their estate. ${ }^{67}$

The moral confusion surrounding the desire for upwards social mobility however, is revealed in a statement made by Lord Palmerston, one of Queen Victoria's Prime Ministers, in the mid-nineteenth century. In a discussion pertaining to Britain's strength and happiness he is cited as saying: -

We have shown the example of a nation, in which every class in society accepts with cheerfulness the lot which Providence has assigned to it; while at the same time every individual of each class is constantly striving to raise himself in the social scale.... by preserving good conduct, and by the steady and energetic execution of the moral and intellectual faculties with which his Creator endowed him. ${ }^{68}$

Only in the latter quarter of the century did the notion of social mobility begin to become acceptable, allowing for commentators such as J. S. Mill to acknowledge that: -

...human beings are no longer born to their place in life... but are free to employ their faculties and such favourable chances as offer, to achieve the lot which may appear to them the most desirable. ${ }^{69}$

By this time the challenge to the domination of the aristocracy by the newly rich industrialists and financiers of the middle classes was no longer simply a threat, but a reality. The aspirations of the wealthy middle classes to join the gentry, the class just

${ }^{67}$ Cited by Chadwick, Owen, The Victorian Church, Part 1, p. 347

${ }^{68}$ Cited by Perkin, pp. 408-9

${ }^{69}$ Cited by Perkin, p. 424 
below the aristocracy, were no longer simply dreams, and by 1879 , one writer at least was commenting on the existence of merchant princes, and merchant peers and statesmen. ${ }^{70}$ At the other end of the scale, on the bottom rung of the middle class social ladder, there was an increasing number of highly skilled artisans who were also looking upwards in terms of gaining social acceptance. This expansion and rise to power of the middle classes has been described as the great phenomenon of nineteenth century social history, ${ }^{71}$ but while there were rags-to-riches stories, in reality there were millions more working class Victorians who were trapped in a cycle of low wages and hard work, and never likely to move out of their narrow existence.

Interwoven with this pursuit for upwards social mobility was the conception that success resulted from a capacity and willingness for hard work. J. F. C. Harrison in his article The Victorian Gospel of Success, comments: -

Stations in life might be clearly marked off from each other, but there was an assumption of a sufficiently high degree of social mobility to make the idea of success widely attractive. ${ }^{72}$

The prestige of position was to a large degree supplanted by the prestige of achievement, ${ }^{73}$ and by the mid-nineteenth century there was a self governing compulsion to succeed through hard work. ${ }^{74}$ This drive for success was encouraged through reams

${ }^{70}$ Escott, T. H. S., cited in Golby, p. 30

${ }^{71}$ Altick, p. 27 72 Harrison, J. F. C., The Victorian Gospel of Success, Victorian Studies, December,
1957, p. 158

${ }^{73}$ Escott, T. H. S., cited in Golby, p. 28

${ }^{74}$ Travers, p. 13 
of popular literature on the ideology of self-help and hard work, which held out the assurance of upward mobility as a reward. ${ }^{75}$ Such literature was not original as there is evidence that a plethora of self-improvement type manuals had flooded the market as early as the sixteenth and seventeenth centuries, praising the virtues of diligence and thrift, ${ }^{76}$ but the "success" literature of the Victorian market was "new" in that it was attempting to provide readers with sound values and useful knowledge about the problems of urban and industrial life and the right tactics for 'getting on. ${ }^{77}$

The most widely known of the Victorian self-help authors was Samuel Smiles, whose book simply called Self-Help, was an international best seller. ${ }^{78}$ The historian, Asa Briggs, claims that the gospel of work, as championed by Smiles, was spread just as efficiently and as fervently as any of the other great nineteenth century missionary enterprises. ${ }^{79}$ Based on a series of lectures given in the 1840 s in Leeds to a group of

${ }^{75}$ Harrison (1971), p. 148

${ }^{76}$ Keating, M. C. P., Clerics and Capitalists. A Critique of Weber's Protestant Ethic Thesis, pp. 41-2. Keating cites almanacs, broadsheet ballads, books intended for the edification of people in general, and some for the business classes in particular; stage plays and prose fiction, as examples of the type of self-improvement literature available in Elizabethan and Stuart times. Asa Briggs (1954) also comments that the concept of setting down the lessons to be learnt from thrift and hard work was not new, despite the claim that the Victorians were the first to proclaim a "gospel of work." The lessons, Briggs says, were considered "old fashioned" in the middle of the nineteenth century.......The sense of gospel may have been new, but the admonition and even the apocalyptic enthusiasm were old. (p. 125)

${ }^{77}$ Briggs, A., in Introduction of Smiles, S., Self-Help, p. 9

78 Briggs, p. 126. Self-Help sold 250,000 copies between 1859 when it was published and 1905. Travers, p. 43, comments that it was translated into 23 languages, including Japanese in the $1880 \mathrm{~s}$ where it was enthusiastically received.

79 ibid. 
working men, Self-Help provided instances of what people had done to achieve success, holding out their examples as models which others might copy. Smiles advocated cheerfulness, ${ }^{80}$ sedulous attention and painstaking industry, ${ }^{81}$ diligence, ${ }^{82}$ and thrift, ${ }^{83}$ as qualities of character that could lead to success. According to Smiles: -

Practical industry, wisely and vigorously applied, always produces its due effects. It carries man onwards, brings out his individual character, and stimulates the actions of others. ${ }^{84}$

Writing for a society that believed implicitly in material progress, Smiles touched the hopes and aspirations of a great many Victorians by encouraging a doctrine of work, which while not directly theological, was nevertheless reminiscent of Evangelical teachings. ${ }^{85}$ The necessity of labour, he wrote,

may, indeed, be regarded as the main root and spring of all that we call progress in individuals, and civilization in nations; it is doubtful whether any heavier curse could be imposed on man than the complete gratification of all his wishes without effort on his part, leaving nothing for his hopes, desires or struggles. $^{86}$

Smiles suggested that it was almost an imperative that people should have to struggle

80 Smiles, p. 118

81 ibid, p. 136

82 ibid, p. 267

${ }^{83}$ Briggs, citing Smiles, p. 138

${ }^{84}$ Smiles, p. 264

85 Harrison (1957) claims that the literature of success was characteristic of a Puritan social morality transmitted to the Victorians by an Evangelical middle class. (p. 160)

${ }^{86}$ ibid, p. 265 
initially to make ends meet, to stimulate their ambitions and drive them to work hard to achieve success. People were prompted to find their station in life through their own efforts, ${ }^{87}$ encouraged to take pride in any difficulties they overcame, ${ }^{88}$ and to take heart, that while progress might be slow, to him who works faithfully and zealously the reward will, doubtless, be vouchsafed in good time. ${ }^{89}$

Industry however, was not the only requisite for success. Thrift was also a virtue ardently proclaimed by Smiles. Simple industry and thrift will go far towards making any person of ordinary working faculty comparatively independent in his means, he wrote. $^{90}$ Anyone in Smiles' thinking, it was observed, could become a capitalist by adding prudence to industry. ${ }^{91}$ The diligent, prudent worker therefore, by the terms of reference of such self-help literature, could reasonably expect to emulate the successful archetypes exemplified by Smiles in his book, thus gaining the objective of respectability that was likely to be the paramount aim.

Wealth, success and respectability, it has to be recognised, were intrinsically entwined, with respectability claimed as the leading virtue of the Victorian era. ${ }^{92}$ Conversely, the

${ }^{87}$ Himmelfarb (1995), p. 168

88 Smiles, p. 296

89 ibid, p. 311

90 ibid, p. 294

91 Briggs, p. 139

92 Newsome, p. 74. Houghton, p. 185, also comments that wealth, respectability and social advancement were all closely associated. 
cult of the so-called respectable classes, was work..$^{93}$ The attributes of character ascribed to the respectable individual - industriousness, diligence, punctuality, regularity, thriftiness - were the same virtues assigned to the gospel of work. It would appear therefore, that work and respectability were the two sides of the same coin.

While respectability has been named as essentially a middle class value, ${ }^{94}$ social history has demonstrated that the working classes equally embraced the virtues surrounding it. In striving for respectability, the workingman set great store on having a job, no matter how lowly. ${ }^{95}$ Working gave a male dignity and self-respect regardless of the wages earned, and a certain independence which in itself defined respectability. ${ }^{96}$ Males were not alone in this need for approbation, as pointed out by Patrick Joyce who comments that, Going out to work, and having the "trade" of weaving to hand, seems to have been a source of pride and respectability to women weavers. ${ }^{97}$ Even the children of the working class, according to Gertrude Himmelfarb, shared with their parents an ethic that work itself was a mark of respectability ${ }^{98}$ It would appear that belief in honest toil and thriftiness as symbols of probity and repute, was not therefore thrust upon an unwilling working class as many had already absorbed the basic tenets of respectability, without

${ }^{93}$ Best, Geoffrey, Mid-Victorian Britain $1851-1875$, p. 78

94 Newsome, p. 75; Houghton, p. 184

95 Himmelfarb (1995), p. 32; Thompson, F. M. L., (1988), The Rise of Respectable Society. A Social History of Victorian Britain 1830-1900, p. 198

96 Himmelfarb, (1995), ibid

97 Joyce, (1980), p. 98

98 Himmelfarb, (1995), p. 36 
the need for a middle class promotion of these virtues. ${ }^{99}$

Incorporated into the notion of respectability was an absolute renunciation of idleness. There is a certain irony in this, considering many of those who were longing for social advancement into the upper echelons of Victorian society and who glorified work, actually valued idleness as a badge of status. ${ }^{100}$ Houghton comments: -

The truth is, however paradoxical it may seem, that the business man who thought of work as a supreme duty dreamed of retiring from work - into idleness; and those who made the idle aristocrat an object of scorn found him also an object of envy. ${ }^{101}$

At the same time those who were relatively financially secure tended to regard idleness as a source of temptation and cause of depravity and disorder. ${ }^{102}$ This apparent incongruity was largely unobserved by the majority of Victorians, and idleness was scorned by both secular commentators and the Church alike. From popular authors, ${ }^{103}$ to churchmen, ${ }^{104}$ to philosophers, ${ }^{105}$ laziness or sloth were censured. In an industrial age the Puritan attitude to idleness became ever more pertinent as entrepreneurs gladly embraced the Evangelical tenet of constant activity. Idleness became a vice, an

99 Thompson, (1981), p. 196

${ }^{100}$ Houghton, p. 190

101 ibid, p. 189

102 Thompson, (1988), p. 274

${ }^{103}$ Newsome, p. 73, cites George Elliott, John Ruskin and Charles Dickens

104 Houghton, p. 245, cites Bishop Newman; Bradley, p. 158, mentions that the Evangelicals spoke out firmly against idleness

${ }^{105}$ Carlyle, pp. 4, 132, 183; Smiles, p. 270 
economic $\sin { }^{106}$ But not just the leaders of the commercial society saw it this way despite a suspicion that industrial work was in bondage to Mammon, Carlyle nevertheless wrote: -

The unredeemed ugliness is that of a Slothful People. Show me a People energetically busy; heaving, struggling, all shoulders at the wheel; their heart pulsing, every muscle swelling, with men's energy and will... ${ }^{107}$

Another writer in Fraser's, a Victorian newspaper, commented in 1851, after praising the increase in commercial wealth and industrial activity, which,

idleness, whether in the higher or lower classes, will not be much longer tolerated - that it will expose the rich man to contempt, and the poor man to punishment. ${ }^{108}$

The assumption implied here that the poor were impoverished because of idleness (rather than due to lack of work or low wages), was a common one in Victorian thinking. The theory that anyone who was virtuous, trustworthy and resolute could always find work if they tried, and that anyone who could not consistently live by their own labour was lazy, infiltrated all levels of society. It was derived from the Puritan notion that God had appointed some people to be poor as a reminder of the curse that humanity would forever toil as its punishment for the Fall. This justification for the existence of poverty overlooked the fact that many of the labouring classes could not find work, and that job security was scarce, leaving the poorer classes vulnerable to the economic mores of the time.

106 Houghton, p. 248

${ }^{107}$ Carlyle, p. 187

${ }^{108}$ Cited by Houghton, p. 248 
In trying to overcome the stigma attached to poverty, and the allusions of idleness, the factory worker in particular, was forced into work patterns that were to the advantage of the industrialists. Patrick Joyce in his study of factory culture in the late nineteenth century, observed,

The pressures that made for dependence produced a commitment to work which was far more than mere rational calculation. Work got more under the skin of everyday life. There is evidence, for weavers and spinners alike, of a willing acceptance, in the cause of work, of both the rigours of authority and of increased workload. Ill and injured weavers would work flat out to avoid the stigma of incompetence. These attitudes amounted to something like the tyranny of work over life.....The limits of work were the limits of life. ${ }^{109}$

The tempo of work increased accordingly. As Charles Dickens put it, the British people were the hardest worked people in the world,,${ }^{110}$ and so ingrained was the belief in selfimprovement through industry and thrift among the employing classes, that they never saw that much of the work was pure drudgery, or that sheer necessity drove the majority of the labouring class.

There were those however, who saw that the factory system degraded the ostensible nobleness of work. ${ }^{111}$ William Morris, for example, detested the debasement of work, and hoped for the day when the dignity of work would be restored. ${ }^{112}$ In his book Useful Work Versus Useless Toil, Morris demonstrated his clear understanding of the

${ }^{109}$ Joyce, (1980), p. 97

110 Cited by Briggs, Asa, Victorian Values, in Sigsworth, E. M.(ed), In Search of Victorian Values. Aspects of Nineteenth Century Thought and Society, p. 13. Briggs continues with the observation that it is significant that Dickens did not say the hardest working, but the hardest worked.

${ }^{111}$ Ruskin and Trollope were among authors who commented on the debasement of work.

${ }^{112}$ Newsome, p. 125 
attitude to work that was innate to many Victorians when he wrote: -

It is assumed by most people now-a-days that all work is useful, and by most well-to-do people that all work is desirable. Most people, well-to-do or not, believe, that even when a man is doing work which appears to be useless, he is earning his livelihood by it - he is 'employed,' as the phrase goes; and most of those who are well-to-do cheer on the happy worker with congratulations and praises, if he is only 'industrious' enough and deprives himself of all pleasure and holidays in the sacred cause of labour. In short it has become an article of the creed of modern morality that all labour is good in itself - a convenient belief to those who live on the labour of others. ${ }^{113}$

Worthy work according to Morris needed to have elements of hope in it - hope of rest, hope of product, hope of pleasure in the work itself. ${ }^{114}$ In reality, despite the vigorous attempts to emphasise the value of work, the work of the labouring classes in particular, were often tedious, and mind-numbing.

In attempting to justify the frequently miserable working conditions of the working classes, and to provide an acceptable meaning for the reshaping of work because of industrialisation, the Victorian work ethic gave a false value to what was often menial, mindless toil. Nevertheless, the "gospel of work" which was instilled in the thought patterns of the Victorians of Great Britain, was carried with the early settlers to New Zealand regardless of its validity or logic. The motives of wealth and success, social mobility and respectability that compelled the workers of Britain to adopt the principles of industry, thrift, diligence, punctuality and sobriety, were also behind the motives that drove many to emigrate to new colonies as will be shown in the next chapter.

${ }^{113}$ Morris, W., cited in Golby, p. 142

114 ibid, p. 143 
PART TWO 


\section{CHAPTER 3}

\section{"The toiler be lord"' (1840-1900)}

In one of the most often quoted phrases about colonial New Zealand, Constantine Dillon wrote to his mother in 1848 , This is a glorious country for a labouring man!!! ${ }^{2} \mathrm{He}$ went on to say: -

No starvation, no fear, no poor law union, high wages, short hours, infinite grazing land for his cows, no doctor's bill; no, not even an accoucheur seems necessary, and very few clothes to keep the cold out. ${ }^{3}$

Is it little wonder that thousands immigrated from Great Britain to colonial New Zealand with expectations of a better life, believing that industriousness and thrift would result in investment and independence unheard of in the home country? Imbued with a puritan work ethic that promised wealth and success as a reward for hard work, and indoctrinated with the propaganda of the colonising agents, many left their homeland convinced that they were heading for a Utopia where they would find unprecedented opportunities and prosperity.

${ }^{1}$ Reeves, William Pember, from his poem entitled New Zealand, at the beginning of his book The Long White Cloud. (No page number) See Appendix 1 for the whole first stanza which is little more than a verse about the work ethic.

${ }^{2}$ Dillon, C. in Sharp, C. A. (ed), The Dillon Letters 1842-1858, p. 65.

Examples of the use of this quotation can be found in Miller, J., Early Victorian New Zealand, p. 125; .Martin, J., (1990), The Forgotten Worker, p. 16; and in Millen, J., as title for Chapter 3 of Colonial Tears and Sweat. I gave up noting such references down after reading the quote in several sources, but subconsciously noted it in other books. Variations of the quote are found in phrases like "the labourer's paradise" in Fairburn, M., (1989), pp. 42, 46.

3 ibid 
But did the original proponents of emigration intentionally and consciously incorporate the "gospel of work" into their reasoning when encouraging the relocation of thousands of Britons? Or was it simply an established mind set, so ingrained in the Victorian psyche that it was an involuntary reaction to the concept of colonisation and emigration to stress the importance and value of industriousness and thrift in new lands?

It appears that while the first advocates of emigration in the early nineteenth century did not emphasise the connection between industriousness and successful emigration, the issue of employment was nevertheless significant. Initially emigration was promoted largely on the basis of Malthusian theories of overpopulation, and his declaration that paupers should be forced to emigrate, with poor relief being denied if they refused. ${ }^{4}$ It could be argued that originally the concept of emigration was seen as little more than a punishment for being poor and probably unemployed, and for many in pre-Victorian Great Britain, emigration simply meant removing an unwanted section of the population - the poor, ${ }^{5}$ and therefore the idle.

However, there were men like Robert Horton, under-secretary for the British colonies from 1828, who, although he agreed with the contention that emigration would relieve the pressure of population, also recognised that if pauper emigrants were to be selfsupporting they needed some capital (in kind rather than money), to enable them to survive in their new land. ${ }^{6}$ It was all very well for philosophers like Thomas Carlyle to

\footnotetext{
${ }^{4}$ Borrie, W. D., Immigration to New Zealand 1854-1938, p. 5

5 ibid

${ }^{6}$ ibid
} 
write of a whole vacant earth calling the British to come and till me, come and reap $m e{ }^{7}$ but it was vital that schemes be set in place for newly arrived emigrants if the excesses of pauper emigration ${ }^{8}$ were to be avoided. With this in mind, it was Edward Gibbon Wakefield, who was to offer new theories that were to lead to colonisation rather than simply random emigration. ${ }^{9}$

Surplus population, poverty and unemployment were not Britain's only problems in the period $1830-40 \mathrm{~s}$. Wakefield was fully aware of the surplus profits generated by the manufacturing and merchant classes, and the irony that just as there was a glut of labour leading to unemployment and poverty for many, there was also surplus capital waiting to be invested. The palliative Wakefield offered was speculation in colonial land that he believed would be not only a useful and profitable employment of money, ${ }^{10}$ but also of labour. Wakefield's theory appealed to the greed of British capitalists, especially when clearly Wakefield did not necessarily expect the investors themselves to emigrate.

However, while it may have been that capitalism was one of the undergirding motivations of Wakefield's theories, he also saw colonies as more than just dumping ground ${ }^{11}$ for surplus money and labour. Along with other visionaries he cherished the

7 Simpson, Tony, (1997), The Immigrants. The Great Migration from Britain to New Zealand, p. 38

${ }^{8}$ Borrie, p. 5

9 Belich, J., Making Peoples, p. 292, describes Wakefield as a major midwife of this change in direction of thought regarding emigration.

${ }^{10}$ Miller, p. 4

11 Borrie, p. 6 
hope that systematic colonisation would see the establishment of a transfigured English agricultural society, free from the polluting effects of industrialism. ${ }^{12}$ A transplanted cross-section of English society was envisaged, ranging from those gentry who could be persuaded not only invest their money in land but also to emigrate, to the traditional sturdy peasant..$^{13}$ By keeping the price of land just outside the reach of the ordinary labourer, and wages high, Wakefield believed that a steady supply of diligent labourers would be induced to emigrate to work the land for the capitalist investors. Given time the industrious and thrifty among the labourers would be able to purchase their own smallholding, and become Master of servants themselves. ${ }^{14}$

Putting the theory into practice in New Zealand was the task of the New Zealand Company led by Wakefield and his associates. The theory, however, was not successful. Disappointed by the Wellington and Nelson experiments, Wakefield agreed to introduce a religious component into the settlements of both Canterbury and Otago on the premise that it had been the lack of religious cohesion that had led to the failure of the other two ventures, ${ }^{15}$ but even with this added dimension, from both a colonisation and business viewpoint, the Company eventually failed. With the land itself not conducive to the arable farming the Company had envisaged, the proportion of labourers to employers

\footnotetext{
${ }^{12}$ Herron, David, Alsatia or Utopia? Landfall, v13(4), 1959, p.325

13 ibid

${ }^{14}$ Sinclair, Keith, (1980 edn), A History of New Zealand,p. 60

15 Olssen, Erik, (1984), A History of Otago, p. 31
} 
totally out of balance, ${ }^{16}$ and little to offer the upper or spending classes,,${ }^{17}$ the experiment was doomed in the form Wakefield had visualised.

Nonetheless, the Provincial Councils, who were responsible for their own immigration policies from the mid-1850s - 1875, followed the principle initiated by the New Zealand Company of advertising for emigrants who were of good character. ${ }^{18}$ This "good character" was assumed to include self-reliance, industriousness, perseverance and sobriety, all aspects of Victorian respectability. The Canterbury Association for example, under the auspices of the New Zealand Company, had required that intending emigrants should produce a certificate from a minister, proving, that the applicant is sober, industrious and honest, and that he and all his family are amongst the most respectable of their class in the parish. ${ }^{19}$

The Provinces in their turn were determined to get equally desirable emigrants and were prepared to follow a range of initiatives to get the "right sort" of people. An example of an advertisement published in London in 1862 promised a free forty acre farm in Auckland Province to every industrious man or woman of good character, and not, through age, infirmity, or other cause, unlikely to form a useful colonist. ${ }^{20}$ The

${ }^{16}$ Simpson, (1997), pp. 70-71

${ }^{17}$ Borrie, p. 6

18 Burns, Patricia, Fatal Success, p. 103; an illustration of a typical New Zealand Company agent's poster advertising emigration to New Zealand states that Strict inquiry will be made as to qualifications and character, p. 199

${ }^{19}$ Cited in Hight, James, \& Straubel, C. R. (eds), A History of Canterbury, p. 170

${ }^{20}$ Sutch, W. B., (1969), Poverty and Progress in New Zealand, p. 80 
immigration policy of the central government introduced in 1870 with the Immigration and Public Works Act, continued this deliberate identification of industriousness as an essential trait for emigrants. Free and assisted passages were offered to industrious persons at home who are not in good employment, and who are not possessed of the means provided they were: -

sober, industrious, of good moral character, of sound mind, free from bodily deformity, in good health, and must be going to the colony with the intention to work for wages. ${ }^{21}$

Julius Vogel, as principal author of the Public Works scheme, believed that it was the personal qualities of the emigrants that would benefit New Zealand and become the country's greatest asset. ${ }^{22}$ In keeping with this opinion, he claimed in 1873 that: -

Every industrious immigrant who is blessed with good health, may rely on success in the colony. The demand for labour is ample, the rate of wages high, the cost of living sufficiently reasonable to enable frugal persons to make considerable savings. ${ }^{23}$

This emphasis on values, which can be attributed to the Victorian "gospel of work," by those responsible for emigration policy, indicates that as the work ethic itself became more commonplace in British thought patterns, so it became assimilated into the strategic planning behind immigration schemes. What had began as merely a vague

\footnotetext{
${ }^{21}$ Eldred Grigg, Stevan, (1982), A New History of Canterbury, p. 23

${ }^{22}$ Basset, Judith, "A Paradise for Working Men 1870-1880,"in Binney, J., Basset, J. \& Olssen, E., The People and the Land, p. 165
}

23 Borrie, p. 63. This statement quite clearly points to a belief in industry and thrift leading to reward. As will be shown throughout this chapter, Vogel was not alone in this conviction. 
requirement for "good character" in the 1840 s progressed to a succinct definition by the 1870 s.

Who were these persons of "good character", sober, industrious, and "going to the colony with the intention to work for wages," who answered the call to emigrate? What drove them to undertake long and dangerous sea journeys to the other side of the world to work $?^{24}$ Perhaps the words of Thomas Chalmers, one of the leaders of the Free Church of Scotland in 1843, best delineate the grounds for emigration: -

Averagely speaking, there must be a great experience of distress and destitution to account for the voluntary exile of thousands from the land of their forefathers. ${ }^{25}$

Distress and destitution were certainly rife in the earlier decades of nineteenth century Britain. The much feared population explosion was a reality, ${ }^{26}$ and there was an increasing concern that the economy was not going to be able to sustain the evergrowing body of humanity. ${ }^{27}$ The industrial revolution, accompanied by the end of the Napoleonic wars, had led to an oversupply of labourers and considerable unemployment. Falling wages meant poverty was endemic, with many living at starvation level. Poor

24 This is said recognising that some were also investing money in land. Hard work however, was essential to bring the land to productivity even for those with money to invest.

${ }^{25}$ Chalmers, Thomas, Problems of Poverty, p. 152

${ }^{26}$ As mentioned in note 18 , Chapter 2, the population more than trebled in the nineteenth century.

27 James Belich comments in his book Making Peoples that migrants took this fear of economic insecurity to New Zealand where it lasted considerably longer than the nineteenth century. (p. 292). 
harvests in the late 1830 s had not helped matters, and protests were becoming increasingly common among working people both in rural and urban settings. Harsh Poor Laws, which were designed in part to encourage "the lazy" to work, separated families. For many emigration seemed an attractive option to avoid the workhouse.

The irony is that alongside the growing wretchedness of the labouring classes, was an expanding middle class with that surplus of capital that Wakefield appropriated for his colonisation plans. This same middle class was increasingly apprehensive of the demonstrations by the poor, and resentful of the rising encumbrance of rates for poor relief. ${ }^{28}$ While Chalmer's "distress and destitution" may not have directly affected them in economic terms, it did in social terms. In his article on Sir Robert Stout, Hamer asserts that it is clear middle class people emigrated to New Zealand: -

to escape the hardening of classes and social division which they felt to be happening around them...New Zealand was to be the classless utopia in which there would be found all the benefits of industrialisation.... without any of its disadvantages, such as class tension and conflict and slum dwelling. ${ }^{29}$

The great majority of the emigrants who were escaping from the conditions in their home country were working class, not those who were completely destitute, but frequently skilled workers and agricultural labourers. ${ }^{30}$ The other class of persons

${ }^{28}$ Hamer, D. A., Sir Robert Stout and the Labour Question, in Chapman, Robert, \& Sinclair, Keith, Studies of a Small Democracy, p. 81

29 ibid, p. 80

30 Simpson, (1997), p. 109; Sutch (1969), p. 41-43; Allan, Ruth, Nelson. A History of Early Settlement, p. 112; Sinclair, Keith, (1980), p. 101; Tautane, Mara, Trade, Guns and Bibles, p. 26 
deemed desirable as emigrants were of course those with capital. Those who came to New Zealand however, were generally people with limited amounts of capital, who thought their chances of increasing their wealth were greater in the colony than in Britain. $^{31}$ Some were the younger sons of old country families ${ }^{32}$ but they were more likely to be middle class merchants and shopkeepers. ${ }^{33}$ Only after the land had been broken in did settlers with any real capital begin to arrive. ${ }^{34}$

Contrary to the stated policy of emigration strategies, it appears that selection procedures were not as stringent as national mythology would have us believe. ${ }^{35}$ Many of the emigrants were illiterate or semi-literate, with educated people a minority. ${ }^{36}$ The claim has even been made that: -

The English rural clergy and employers discouraged the best type of agricultural labourer from emigrating, but adopted a different attitude towards undesirables and those likely to be a charge on the parish rates. ${ }^{37}$

${ }^{31}$ Marais, J. S., The Colonisation of New Zealand, p. 61

${ }^{32}$ ibid

${ }^{33}$ Olssen, Eric \& Stenson, Marcia, A Century of Change, p. 133

${ }^{34}$ Marais, p. 142

${ }^{35}$ Olssen \& Stenson, p. 133; Herron, p. 329: McClintock, A. H., The History of Otago, p. 229

${ }^{36}$ Herron, pp. $329-330$

37 ibid, p. 328. Keith Sinclair (1986) in A Destiny Apart. New Zealand's Search for National Identity, suggests that there is inconclusive evidence that indicates that the labourers who migrated were the steady workers. (p. 69). This does not necessarily contradict Herron's statement as there is nothing to say that the so-called "undesirables" and those likely to cost the parish, were not steady workers given the opportunity. 
Despite such an assertion, it took courage to emigrate to the other side of the world.

Along with courage, these young emigrants, however "suitable" or not they may have been compared with proclaimed selection procedures, also showed considerable initiative, and according to one writer, untiring industry and unwavering tenacity of purpose. $^{38}$

Careful selection procedures or not, the Reverend Thomas Burns, one of the founders of the Otago colony, is cited as saying: -

In all my experience, I know of no parish, no community of equal size, containing anything like so large a proportion of individuals distinguished by very high character for intelligence, for moral worth, for patient, active industry, and especially for a very serious regard to their religious duties. ${ }^{39}$

The Scots who emigrated have been repeatedly described as industrious, thrifty, vigorous and self-reliant, ${ }^{40}$ although not all who were among them necessarily credited their peers with these qualities. One Otago settler for example wrote: -

The labourers by the Philip Laing are not quite the sort of people wanted here.

38 Sinclair, (1986), p. 12, citing A. Rugby Pratt. This was true not just of the Scots and other Britons who emigrated. Over the nineteenth century, German, Scandinavian and Chinese immigrants also arrived in New Zealand. Wakefield was convinced that German settlers in the Nelson area would set the same example of frugality, industry and sobriety that he had seen in their fellow countrymen. (Cited in Allan, p. 317-8). The Chinese who arrived originally in response to the gold rushes of the $1860 \mathrm{~s}$, but who then settled in New Zealand, were described in a report on Chinese Immigration in 1872, as frugal and industrious. (Borrie, p. 58). A comment made by "Hopeful" in her book Taken In, praises the Chinese for being patient and industrious... extremely frugal and sober in their habits .(p. 132). The Scandinavians who arrived in New Zealand in the early 1870s quickly earned themselves a reputation for being industrious and frugal, and diligent and hardworking. (Borrie, p. 59)

39 Cited in Kitson, Jill, Great Emigrations. Vol.2. p. 81

40 Olssen, (1984), p. 34; Herron, p. 329; Kitson, p. 81; Bassett, J., "A Paradise for Working Men" 1870-80, p. 171; McClintock, p. 154 
They are mostly weavers and miners. They are besides a mixed set as regards their general character...All the labourers ask for exorbitant wages, which private individuals cannot afford to give. People must work, therefore, a good deal for themselves. ${ }^{41}$

What this anonymous settler did not appear to realise, is that these labourers had nothing but their ability to work to bargain with. The weavers and miners had been supplanted by the mechanics of the industrial revolution and had little or no opportunity to be anything but poverty stricken, unemployed or underpaid labourers in Scotland. ${ }^{42}$ They had turned to emigration as a chance to gain an independence and financial security denied them in their homeland. ${ }^{43}$

This was probably the primary motivation behind much emigration to New Zealand. Guarantees of work by the New Zealand Company in the early years of the colony, followed by similar promises by provincial and central government from the $1860 \mathrm{~s}$ to the 1880 s, enticed many to emigrate. The temptation to escape from poverty, or the fear

\section{Letters from Otago (1848-1849),p. 14, cited from New Zealand Journal, 21 October, 1848:242}

${ }^{42}$ My forebears (Thomas and Mary Cuddie) who came to Otago on the ship the Philip Laing in 1848 were displaced cotton weavers from Maybole in the Ayrshire region where the Rev Thomas Burns had been based after the Disruption. After some years of employment as a labourer in the new colony, Thomas Cuddie had saved enough money to buy land, and he and Mary set about establishing a farm on Saddle Hill. After Thomas' death, Mary went on to own a general store in Mosgiel, and in 1882 she is listed in the Return of Freeholders as owning property both on Saddle Hill and in Mosgiel, worth over thirteen hundred pounds. In the late 1880 s one of the Cuddie's sons established the first dairy factory in the South Island exclusively dedicated to producing butter. The Cuddies were an example of the stereotype Scots emigrant family - industrious, thrifty, sober, and totally committed to the Church. They proved that hard work and thriftiness led to success. These are the sort of people the anonymous settler quoted was maligning as not being "suitable." ( The story of Mary Cuddie is told in The Advance Guard, Series 2, 1974, pp 151-178)

${ }^{43}$ McClintock, p. 236. 
of potential poverty, and the possibility of breaking loose from the rigid British class system and being one's own boss, were lures not easily ignored, especially if opportunity in the homeland was slight.

The evidence shows that the majority of contemporary accounts give as the reason for emigration, a desire to better oneself. ${ }^{44}$ Depressed by conditions in their homeland, would be emigrants were convinced that there had to be a better life in the colony where they believed there would be a means to make a living, and an opportunity for their children to have a prosperous future. Sarah Greenwood, for example, preparing to be among the first settlers to Nelson, wrote to her grandmother in 1842: -

You know also the extreme difficulty of finding employment in England, even for single men; how much more then for a numerous family? Then again in a few years we shall have sons to place out, and only think of the many anxieties experienced by parents with money and connections to back their endeavours, and you will feel what a comfort it must be to reside in a Country where every young person of good conduct is sure to meet with profitable employment. ${ }^{45}$

The concept of a "better life" included not only employment, material comforts and money, but also the possibility of ownership of a home and land. The indication from land ownership figures in the early 1880 s is that for many emigrants the possibility of

${ }^{44}$ Simpson, (1997), p. 130. One anonymous comment cited in Millen points out that men emigrated to get work, but women emigrated to get married. (p. 63). In either instance "bettering oneself" or "getting on" was the ultimate motive.

45 Cited in Porter, Frances, \& Macdonald, Charlotte, "My Hand Will Write What My Heart Dictates", p. 63. It is however interesting to note a comment made by H. R. Richmond to Jane Maria Richmond in a letter dated 15 July, 1851, which reads as follows:-... for an unmarried and unlikely to marry family with nothing very definite to work hard for...I cannot feel this is the right place... (Scholefield, p. 99-100). It would appear from this that much of the incentive to work came from having to support a family. 
some sort of "land-based" independence was a fundamental goal. ${ }^{46}$ One Taranaki settler who recognised this wrote home to family: -

...the delight of having a place of one's own is by no means an imaginary one and I have no doubt that a scheme assisting poor emigrants is a very practicable one... ${ }^{47}$

Yet another observer commented: -

To find a home; this the desired object of many. ${ }^{48}$

In juxtaposition with this desire for independence through land ownership and financial security, went an ambition to improve one's standing in society. Labourers and lower working class people aspired to the respectability that ownership of land would bring, while middle class people, who felt they had been ignored by their social superiors and prevented from rising above their station in Britain, saw themselves as the gentry in their new land. ${ }^{49}$ As New Zealand developed a reputation as a place where intending emigrants could improve their situation, it became increasingly attractive to those restless to leave Britain and its social and economic circumstances. But did it deserve this reputation?

\footnotetext{
${ }^{46}$ Fairburn, Miles, (1989), The Ideal Society and its Enemies, p. 45. Fairburn bases this on the fact that $25 \%$ of manual workers were landowners by the early $1880 \mathrm{~s}$.

47 Scholefield, Guy H., (ed), The Richmond-Atkinson Papers, p. 89, H. R. Richmond writing to C. W. Richmond, 3 April, 1851

${ }^{48}$ Fairburn, (1989), citing Reverend Richard Taylor, 1855, p. 144

49 Fairburn, (1989), p. 46; Olssen \& Stenson, p. 133; Hartley, Nell, Colonial Outcasts, p. 21
} 
According to one "Maggie" of unknown surname, who wrote a book called Taken In

during the late 1880 s under the authorship of "Hopeful," there was a great deal of

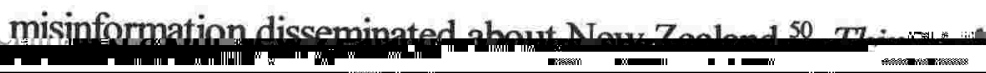

(n) (1)

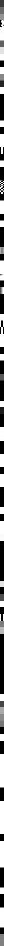


the amenities of life. ${ }^{56}$ Much of the propaganda literature howeyer was not promoted through official channels. James Belich makes the observation that while high wages and good living conditions were officially promised the concept of a labourer's paradise was not fostered by those he describes as the crusaders. ${ }^{57}$ It appears instead that much of the exhortation came from private individuals. Publications from the early 1840 s on gave euphoric accounts of settlers' opinions or experiences, as for example this extract from a letter to the editor of New Zealand Journal in 1842: -

The larger a man's family, the better are his prospects; if his children are brought up to industry, any man with two or three hundred pounds, with a useful family, may buy a snug freehold farm, become an independent proprietor, and leave his children after him, in one of the most delightful countries in the world. ${ }^{58}$

This was a common refrain. ${ }^{59}$ Others spoke of the great potential for settlers to be successful, ${ }^{60}$ to own their own estates, ${ }^{61}$ to share in the advantages afforded by a new

${ }^{56}$ Herron, p. 328. Herron goes on to point out that many left New Zealand within a few years when they realised that things were not going to be as they expected. Out of the 436 original colonists to Wellington only 80 were still in New Zealand by 1848 .

57 Belich, p. 309

58 Letters from Settlers and Labouring Emigrants in the New Zealand Company's Settlements of Wellington, Nelson and New Plymouth, from Mr. Francis Bradey, 3 February, 1842.

59 Hursthouse, Charles, New Zealand, the "Britain of the South", pp. 255, 257; and Cooper, I. R., cited by Fairburn (1989), p. 42, both wrote of improving the prospects of their children through hard work which in turn leads to an improvement in fortunes. Sarah Greenwood, quoted earlier, also fits into this category.

60 For example Belich, p. 309, cites Arthur Thompson, 1859, speaking of the many chances for success.

61 Buller, James, Rev., Forty Years in New Zealand, p. 450; Fairburn (1989), citing Arthur Clayden, p. 47 
and uncrowded field for industry and speculation, ${ }^{62}$ and to join the ranks of the respectable. $^{63}$ The promise of independence was held out to those who were industrious and thrifty, ${ }^{64}$ and to those who were prepared to practice temperance and self-denial. ${ }^{65}$ The common catch cry was the willingness to work. If a person was healthy, industrious and honest, the necessities of life were to be had in abundance. ${ }^{66}$ Independence and prosperity would be ensured ${ }^{67}$ if individuals showed steady, industrious and careful habits. ${ }^{68}$ Productiveness of the land was guaranteed because of the abundance of natural resources and fertile land - all that was required to convert nature's plenitude of riches into personal prosperity was hard work. ${ }^{69}$

The emphasis on the necessity to be a willing worker, however, was also a warning to those who have not learned how to work. ${ }^{70}$ Swainson, for example, cautioned that: -

${ }^{62}$ Adams, C. Warren, A Spring in the Canterbury Settlement, p. 20

${ }^{63}$ McClintock, p. 229, cites from the Otago Journal, no. 3, November, 1848

${ }^{64}$ Swainson, William, New Zealand and Its Colonization, p. 193

${ }^{65}$ The Handbook to the Suburban and Rural Districts of the Otago Settlement, no page numbers.

${ }^{66}$ Cowie, William Gordon, (Bishop of Auckland), Our Last Year in New Zealand, p. 306, January, 1888; also Hursthouse, p. 257 and Swainson, p. 193, reflect similar viewpoints.

67 Swainson, p. 194; The Handbook to the Suburban and Rural Districts...., no page numbers

68 ibid, The Handbook... It must be noted however that The Handbook did caution readers not to be led away by any representations whatever to look on this Settlement as an El Dorado, or an earthly paradise. Success would only be preceded by hard work.

69 Fairburn, Miles, Social Mobility and Opportunity in Nineteenth Century New Zealand, New Zealand Journal of History, v13 (1), April 1979, pp 43-64

${ }^{70}$ Fairburn, (1989), citing Alfred Saunders, p. 53 
For those .. who have already failed at home - for decayed tradesmen, for clerks and shopmen, for candidates of Government employment, for young men who hove neither capital nor skill and who are too proud or too weak to earn their bread by the sweat of their brow - New Zealand cannot be recommended as a field of emigration. ${ }^{71}$

Other observers remarked that those who were good for nothing ${ }^{72}$ at home were hardly going to do any better in New Zealand, unless they were ready to do a good hard day's work at some physically laborious employment when they arrived in the colony. Otherwise they had better be idle at home than here. ${ }^{73}$ Stories told to freshly arrived settlers about the horrors of the new country were going to be ruinous to the indolent and desponding ${ }^{74}$ but a challenge to those who were amenable to hard work. Good, steady men were sure to do well, the lobbyists promised.

Considering the wealth of propaganda praising the colony it is interesting that those who mistakenly saw New Zealand as a new El Dorado were spoken of with considerable derision. A Wellington resident in 1842 wrote to a New Zealand landowner residing in England: -

It is really lamentable to witness the want of courage and industry in a large number of the young men who come here. They arrive with the idea that they are to have no difficulties or discomfort to contend with, yet most of them have fled from home in despair at the dismal prospect they were abandoning. ${ }^{75}$

71 Swainson, p. 193

72 Thomson, Mrs Charles, Twelve Years in Canterbury, New Zealand, p. 2

${ }^{73}$ Butler, Samuel, A First Year in Canterbury Settlement, p. 68. It is interesting to note that both Mrs Thomson and Butler indicate that those unsuitable persons who came to New Zealand were likely to become worse than they were at home or to take to drink.

\footnotetext{
${ }^{74}$ Adams, p.20

${ }^{75}$ Letters from..., p. 23
} 
The same went for those who came to New Zealand expecting to be gentlemen, without any exertion on their part. ${ }^{76}$ It would be much better if they had stayed in Britain. Only contempt was shown for the "remittance" man who arrived in New Zealand to live off money sent from Britain, while contributing nothing to the colony. ${ }^{77}$ Even the Official Handbook of New Zealand for 1875 expressed this aversion: -

That the ne'er-do-well had better continue to sponge on his relations in Great Britain, than to hope he will find sympathy for his failings and weaknesses in a land of strangers; strangers, moreover, who are sufficiently impressed with the active and hard realities of life, and who being architects of their own fortunes, have no sympathy to throw away on those who are deficient in selfreliance. ${ }^{78}$

There is little doubt that a person's worth in colonial New Zealand was measured by the sweat of their brow. ${ }^{79}$ There was a certain pride taken in proving one's endurance in taming the new land through physical exertion and strength, especially among the men. ${ }^{80}$ Physical prowess may have been all some settlers had to offer, but there was a clear

76 ibid, p. 95, cited from a Nelson settler, D. Moore, in a letter to friends in England, 1842

${ }^{77}$ Phillips, Jock, A Man's Country? p. 16

${ }^{78}$ Cited in Hartley, p. 17

79 ibid, 173; Phillips, p. 16

${ }^{80}$ Phillips, pp 5, 11. This is not to suggest that the women had an easy life. Women frequently worked extremely long and hard besides their menfolk on the farm and then went inside to do the housewifely tasks expected of them. Such examples can be found in Toynbee, Claire, Her Work and His, p. 47; Simpson, Helen, The Women of New Zealand, p. 109; Soper, Eileen, The Otago of our Mothers, p. 38; Brookes, Barbara (et al), Women in History. Essays on European Women in New Zealand, p. 60. 
understanding that anyone who was willing to work and use his hands would succeed, ${ }^{81}$ especially if they demonstrated adaptability and versatility. Even the most hardened men, it was recognised, were imbued with a dedication to work. For instance, J. C. Richmond wrote to his mother: -

A colonist who thinks nothing of living with a Maori mistress, of steeping himself... in grog and swearing and cursing in the most atrocious way has still got the germ of a notion of something outside his own desires that has a claim on him. He looks with contempt on the savage that drops his tools as soon as he is tired and does not feel that he ought to go on till his fair day's work is done. $^{82}$

The wealthier of the emigrants, compelled to work just as hard as their employees, justified their menial labour and drudgery with recourse to the virtues preached by the "gospel of work." Some even appear to have taken genuine pleasure in hard manual work, perhaps with the notion reiterated by Robert Godley subconsciously in their minds. In his farewell speech on leaving New Zealand, Godley is quoted as saying, It is the business of man, and most of the noblest men, to work, to struggle, and to strive. ${ }^{83}$ Godley proclaimed that it was the duty of colonisers to assert the nobleness of work, work of any kind, so that it be hard and honest work. ${ }^{84}$ With this in mind is it surprising that a "genteel" Taranaki settler, H. A. Atkinson, later to be Premier, wrote to an aunt: -

${ }^{81}$ Letters from... p. 105; Fairburn (1989) citing Alexander Bathgate, p. 43

${ }^{82}$ Scholefield, p. 91. This statement is also a reflection on how the work ethic of the Maori was perceived.

${ }^{83}$ Godley, John Robert, Writings and Speeches, p. 178. Godley, a founding father of the Canterbury settlement, was a committed High Church Anglican. Further reference will be made later to his "preaching" about work.

${ }^{84}$ ibid, pp. 174-5 
It is rather rough work at first in the bush... [but] you awake on the morrow with the fresh strength to do your share in the glorious work which is set us, of subduing and replenishing the earth. ${ }^{85}$

It has been suggested that the moral and religious proclamation of the work ethic resulted in some of the more cultured New Zealand immigrants associating hard work with moral regeneration, and with being of value, ${ }^{86}$ which would account for the seeming pretentiousness of such statements. This "being of value" through work is reflected in the letters and memoirs of gentlewomen as well, in particular in this passage from Jane Maria Richmond some months after arriving in the Taranaki. She writes: -

I am afraid I have the soul of a maid of all work, and whether I shall ever be anything better seems doubtful. Lely [her mother] seems rather disgusted at seeing me scrub about and look as dirty as I do when at dirty work, but I consider myself a much more respectable character than I was when I was a fine lady, did nothing for anybody but made a gt. many people do things for me...Lely talks about me being a slave, but I really feel myself less a slave now that I see I can do everything for myself, than I ever did before. ${ }^{87}$

For all the admirable belief in the virtue of work held by the capitalist gentry and uppermiddle class immigrants, and the industriousness of the labouring classes, there was no guarantee that hard work would result in wealth. Only a few made it lucky despite claims by some early settlers that anyone who was prepared to work with their hands would soon grow rich ${ }^{88}$ Although in Canterbury and Otago a "landed rich" developed,

${ }^{85}$ Scholefield, p. 157

${ }^{86}$ Belich, pp. 326-8

${ }^{87}$ Scholefield, pp. 133-4

${ }^{88}$ Simpson, (1997), citing Martha Adams (early 1840s), p. 92; Pratt, W. T., Colonial Experiences, p. 285 
it has been claimed that wealth in the colony generally originated from inheritance, capital gains, access to credit, land distribution, and the development activities of provincial and central governments, ${ }^{89}$ rather than simply through hard work. It did not matter how industrious, thrifty and self-reliant a person was, if they had no capital behind them they were unlikely to make their fortune, ${ }^{90}$ and from an early date it was recognised by some settlers that capital was all important if the colony was to progress. Labour alone was not enough. Constantine Dillon, ${ }^{91}$ for example, wrote to his mother in 1844: -

Can an industrious man with no capital obtain a decent living for his family?...... I would briefly recommend such a man not to come here, and for this reason, that capital and labour bear no proportion to each other in this settlement. We want capital. I have no doubt that had we capital to call forth the resources of the country we should progress rapidly.......Now, about those with capital, I will say that if a great number of persons with capital emigrated they would do very well for themselves and for the country...The principal want here is, I say again, capital to employ the labour, and to bring forth the resources of the country. ${ }^{92}$

Nonetheless the primary goal of many immigrants was to make money, ${ }^{93}$ and Samuel Butler points out that making money was the inducement that brought numerous people to New Zealand. ${ }^{94}$ By 1888 the New Zealand Handbook, however, realistically

89 Fairburn, (1979), p. 55

${ }^{90}$ Eldred-Grigg, Stevan, (1996), The Rich, p. 55, citing Russell Stone.

91 Of "This is a glorious country for a labouring man!" fame

92 Sharp, pp. 37-8

93 "Hopeful", p. 167

94 Butler, p. 50. There were probably not many like the Richmond brothers who according to their sister Jane Maria Richmond, did not go to make their fortune, but to 
emphasised that there was no more chance of making a large fortune in New Zealand than elsewhere, although careful and industrious emigrants would make a reasonable living. ${ }^{95}$ Those characters described by "Hopeful" as money-grubbing to the depth of their souls ${ }^{96}$ might still make the bid to accumulate wealth in New Zealand but at least they had been warned of the unlikelihood of succeeding.

Those who were did find wealth did not necessarily handle their new found affluence adeptly, especially in relating to their fellow immigrants. "Hopeful" wrote: -

Those who have done well in money matters often stand aloof, not caring to associate with former acquaintances who have not been so successful, and this feeling is most exhibited by those whose sphere was particularly humble at home - the rise they have been better able to accomplish in these lands has inflated them greatly. ${ }^{97}$

Myths that social divisions did not exist in the new colony were rampant back in the homeland where people were led to believe that "Jack was as good as his master", but the reality was quite different as her comments demonstrate. Although many emigrants had come to New Zealand to escape the class associations of Britain, it has been said that social climbing was a game played feverishly and in deadly earnest. ${ }^{98}$ Throughout the country there were people struggling to rise a class or two, although the indication

found a home where they can have abundant employment. (Scholefield, p. 62) It has to be said however that the Richmonds obviously had capital to start with, as Jane talks about the employment of their capital in safety, and the fact that they need work no harder than we like.(Scholefield, p. 61)

${ }^{95}$ Fairburn, (1989), p. 43

96 "Hopeful", p. 175

97 ibid, p. 119

${ }^{98}$ Eldred-Grigg, (1996), citing Helen Mary Ostler, p. 37 
is that social mobility tended to operate both ways. ${ }^{99}$ Dreams of land ownership, for example, were all too frequently turned on their head when immigrants found themselves relegated to being wage labourers on someone else's property, ${ }^{100}$ and despite the illusion of some that the New Zealand labourer was thought of as just as fine as an English gentleman, ${ }^{101}$ the ongoing distinction between employers and workers was nevertheless discernible. The following advice for instance, was given to one prospective station holder: -

...no gentleman should ever do hard work with one of his men, because either the man would go slow as not to shame his employer, or the employer would knock himself up trying to get full work out of the man. ${ }^{102}$

Ambition, however, was part of the prevailing environment and few immigrants would have been able to avoid raising their aspirations when they saw that some around them were actually succeeding in buying land and getting on. ${ }^{103}$ Accompanying this sense of ambition was the determination of many immigrants not to perpetuate the class system. To Wakefield's surprise his scheme for maintaining the mores of the British social order was a failure from the start as there were very few immigrants who wanted to sustain the old ways. Undoubtedly the adversity of the early years of settlement was a great leveller but the subservience traditional to the lower classes appears to have been shed with the

\footnotetext{
99 Martin, John, Wither the Rural Working Class?, New Zealand Journal of History, v 17 (1), 1983, p. 41

${ }^{100}$ Eldred-Grigg, Stevan, (1990), New Zealand Working People 1880-1990, p. 30

101 Rollo, Arnold, The Farthest Promised Land, citing James Randall, p. 11

${ }^{102}$ Martin, (1990), p. 52, citing H. J. Tancred

${ }^{103}$ Rollo, p. 256; Belich, p. 293
} 
very act of emigration. Society was definitely more open than it had been in Britain, and there were numerous stories told of immigrants who developed into men of substance, ${ }^{104}$ acquired their own farms, ${ }^{105}$ or developed their own businesses. ${ }^{106}$ In the early $1880 \mathrm{~s}$ one commentator wrote: -

... the labouring classes are too well off, and the rungs of the ladder of material advancement are so close upon each other, and so many have mounted from the spheres of the labouring man to that of the deferred payment renter, and from that again to the independent free holder, that the elements of class antagonism, so frequent elsewhere, are wanting here. ${ }^{107}$

Industry, thrift and perseverance were of course the catch words explaining the achievements of those who were successful in climbing the social ladder. ${ }^{108}$ The words in themselves were cherished by the middle class, that very class coveted as the ultimate goal by most of immigrants. As Thomas Cholmondeley observed: -

.the life of the poor working emigrant represents an incessant struggle to get into the middle class; he hates the individual; but he likes the position. The middle class is all in all in the colony. ${ }^{109}$

${ }^{104}$ Eldred-Grigg, (1982), citing Alfred Cox, p. 55. Eldred-Grigg also cites James Buller making a similar comment (p. 55).

${ }^{105}$ The observation has been made frequently that Wakefield did not expect the labouring classes to be able to buy land and rise from their place in society as rapidly as happened in the first decades of settlement. Marias claims that by the 1850 s the small farmer was a main component of New Zealand society. (p. 171)

106 Boyd, Judi, \& Olssen, Eric, The Skilled Workers: Journeymen and Masters in Caversham, 1880-1914, New Zealand Journal of History, v 22 (2), 1988, p. 124

107 Hall, David, The Golden Echo, citing Falconer Larkworthy, p. 179

108 Boyd and Olssen also suggest that an expanding economy, good luck, good health, a willingness to move, and a sensible marriage were in most cases the necessary preconditions for achieving success. (p. 179)

${ }^{109}$ Sinclair, (1980 edn), citing Cholmondeley, p. 102 
During the last decades of the nineteenth century it has been observed that as an urban class of self-made men emerged, the middle class, or bourgeois, ethic of hard work, blossomed. ${ }^{110}$ Status became paramount in their ambitions once they had proved their worth through hard work, thrift and self-improvement, and just as the wealthy among the landowners aspired to live a life of ease, ${ }^{111}$ so did the urban capitalists. ${ }^{112}$ By the end of the century the social order left behind in the homeland had reinstated itself, simply with different players.

It is important to acknowledge that there were a significant number of immigrants who never even reached the first rung of the ladder to success. The same scandal of unemployment that had been instrumental in driving many from Britain reappeared within only a short time in the new colony. The prospect of guaranteed work that had tempted so many to emigrate, quickly became a lie for a considerable number, and

${ }^{110}$ Phillips, p. 49

111 There is a fascinating glimpse into the life and attitudes of the wealthier settler in a letter from Jane Maria Richmond to her mother in 1858. Written in response to a letter from friends trying to persuade the family to move from the Taranaki to Canterbury, Jane writes: -

I couldn't help laughing at the picture of our mob's* wasted energies here and the "incessant toil for any number of years" which can bring no result. With the exception of the first year and a half here, I should say that most of the energy as been expended in riding around and enjoying themselves, and that the incessant toil has been consistent with a larger amount of whole and half holidays than absolute health rendered necessary.... With the exception of Henry's case there has not been the steady persevering industry displayed which can alone ensure worldly success in any imaginable walk, unless sit be in the business of pure gambling...(Scholefield, p. 412)

[ * the Richmond and Atkinson families called themselves "the mob" ]

112 Eldred-Grigg, (1996), p. 124 
records show that unemployment and destitution were common in all the early settlements. ${ }^{113}$ The philosophy of the right to work rapidly became an issue for workers in New Zealand Company settlements who had been assured of employment by the Company itself if necessary. In Nelson in particular, disaffected immigrants unable to obtain proper employment, protested against their forced dependence on the subsistence rates paid by the Company. In a petition to Captain Arthur Wakefield in 1843, less than one year after their arrival, it was stated: -

...we did not come here under the dishonourable appellation of Convicts.....but with characters that would bear the strictest scrutiny as honourable and Industrious men wishing only to live by our Industry and, to procure a comfortable maintenance for ourselves and our families. ${ }^{114}$

...for no man is so happy as the working man for when his day's work [is done], he comes home to his family and by his own fireside he enjoys or should enjoy the fruits of Industry. We do not want large fortunes or Extraordinary Incomes but to live comfortably and decently. ${ }^{115}$

The disillusionment of these three hundred unemployed Nelson settlers was echoed in pockets throughout the country, but the ingrained belief inherited with the Victorian work ethic, that lack of a job was a personal fault, meant that those without work were treated with disdain. Even in the 1880 s when economic recession was widespread, politicians were still encouraging industrious persons to emigrate to New Zealand, and tending to relate unemployment to laziness. William Rolleston for example, is quoted as saying, We have still the unemployed in Christchurch, but they are hopeless

${ }^{113}$ Sutch, (1969), p. 43

${ }^{114}$ Cited in Sutch, W. B., (1966), The Quest for Security in New Zealand 1840-1966, p. 17

${ }^{115}$ Cited in Allan, p. 187 
loafers....People now coming are a good sort... ${ }^{116}$ This despite pleas from the unemployed to stop continued immigration plans, and commentators like "Hopeful" remarking that publicity in the United Kingdom claiming ample opportunity for employment in New Zealand was denying the reality of the situation. ${ }^{117}$

For many of the unemployed the only option was to become nomadic as they searched for work. Seasonal and casual employment for agricultural labourers meant not only irregular wages, but also the development of a habitual transience which was as an anathema to the respectable, hardworking, sober and struggling farming family. ${ }^{118}$ The immigrants who had striven to acquire land and had settled in one place, saw the itinerant work force as somehow frighteningly alien, a group of individuals who had not assimilated the values of hard work and thrift. ${ }^{119}$ It was largely ignored that it was sheer necessity that drove men to wander the countryside looking for work. The middle class belief that procurement of property was an indication of reward for hard work and moral living, resulted in what Fairburn has described as an "anxiety" towards those who deviated from the customary code for society. The itinerant worker or "swagger," he suggests, was a symbolic figure who helped sustain the unconscious anxiety of many of the settlers. ${ }^{120}$

116 Cited in Borrie, p. 138

117 "Hopeful", p. 174

118 Martin, (1990), p. 30

119 ibid

120 Fairburn, (1989), p. 245. I can only assume that the anxiety was also in part rooted in the fear that what had been acquired, would be lost, and that the settled immigrant would find themself in the same position as the very men they were criticising. Phillips 
Perhaps in an attempt to alleviate this anxiety a distinction was made between the "decent" and the "shifless" poor. ${ }^{121}$ The swagger, that colonial bogeyman, was branded as a member of the shiftless poor, one who would not settle down, and preferred to shift from job to job. The reality was that most of the swaggers were probably legitimately in search of work, ${ }^{122}$ but the ultimate denial of an unemployment problem led to a hardening of judgment against them. Even while recognising the wanderer who was decent and hardworking, contemporary writers condemned most swaggers as being: ... idle, "blowing", undesirable, sponging alike on the runholder, the farmer, and the hotel-keeper - an individual who won't work unless he is obliged, and sometimes not even then; a disgrace to his kind, and fit only to be classed with the "casuals" of an English workhouse. ${ }^{123}$

Other writers described them as erratic birds of passage with no interest in their work, ${ }^{124}$ as a pestilence, ${ }^{125}$ and as a source of annoyance because while they professed to be in search of work, in reality they did not want it. ${ }^{126}$

(p. 40) also makes similar observations to Fairburn, commenting that there was a crucial moral distinction...between the industrial frugal settler... and the drifter or ne'er -dowell... who carried his swag from one job to another. The middle class was threatened by the values and habits of the principally male culture of the itinerant work force.

${ }^{121}$ Eldred-Grigg, (1982), p. 60

${ }^{122}$ Martin, (1990), p. 30

${ }^{123}$ Bradshaw, John, New Zealand As It IS, p. 26

${ }^{124}$ Cited in Martin, (1990), p. 30

${ }^{125}$ Eldred-Grigg, Stevan, ( 1980), A Southern Gentry, p. 53

${ }^{126}$ Bathgate, p. 212 
With hindsight, some older New Zealanders looking back to the end of the nineteenth century in discussions with John A. Lee, ${ }^{127}$ acknowledged that many swaggers had been anything but lazy. Lee describes a pioneer New Zealand of great working-class athletes, when men were known for their working ability from end to end of the colony..., ${ }^{128}$ and some swaggers were known and respected for their capacity to work from Blenheim to the Bluff. ${ }^{129}$ One Jock Mckenzie for instance, was well known for his legendary feats of work, and was believed when he boasted he could outwork and outwalk any man in New Zealand. ${ }^{130}$ This evidence of an overlooked work ethic among the itinerant work force, is supported by Fairburn's study of James Cox, ${ }^{131}$ a labourer who arrived in New Zealand in 1880. Cox, it is said, hated the long spells of unemployment, because they violated his belief in the virtues of work. ${ }^{132}$ Fairburn claims that from Cox's diary that it is clear he was industrious, conscientious, thrifty, sober, self-disciplined, reliable, and possessed of a great capacity for perseverance, ${ }^{133}$ all supposed virtues which would lead to success. And yet, despite what Fairburn describes as Cox's powerful work ethic, he was an economic failure, ${ }^{134}$ and died a pauper.

\footnotetext{
${ }^{127}$ These discussions took place in the $1930 \mathrm{~s}$

${ }^{128}$ Lee, John A., Roughnecks, Rolling Stones and Rouseabouts, p. 10

129 ibid, pp. $14-15$

130 ibid, p. 15

131 Fairburn, Miles, Nearly Out of Heart and Hope. The Puzzle of a Colonial Labourer's Diary, (1995.)

132 ibid, p. 138

133 ibid, p. 142

134 ibid, p. 142
} 
With an attitude prevalent, among the middle class in particular, that work was a duty not a right, ${ }^{135}$ the unemployed, and the swaggers, were treated with considerable bias. There was an extreme aversion to arranging any type of relief for those who were experiencing hardship because of unemployment, ${ }^{136}$ the general rationalisation being that those without work were lazy and shiftless. The antagonism towards claims for provincial, and then government assistance, was probably largely due to the reluctance by settlers who had succeeded in their new country, and politicians who were still encouraging emigration, to acknowledge that conditions were increasingly beginning to resemble the ones they had left behind in Britain. ${ }^{137}$ The thought of having to provide the equivalent of poor relief, or a system of compulsory work, was abhorrent in the new world. ${ }^{138}$ With a memory of the professed economic drain on the middle classes having to provide poor rates back in Britain, politicians like Robert Stout warned the Parliament

\footnotetext{
135 Campbell, R. J., "The Black 'Eighties" - Unemployment in New Zealand in the 1880s, Australian Economics History Review, v 17(2), 1976, p. 74
}

${ }^{136}$ Even in the Nelson area where unemployment was rife within months of the settlement being established, the New Zealand Company which had undertaken to provide work for immigrants until they were able to get other employment, was slow to respond to the needs of its settlers. Admittedly lack of capital did not help the position but the Company was reluctant to provide relief without the labourers working for their keep. Despite protests by the labourers, the Company reneged on the amount they had guaranteed to pay those without work, and sent the men on their "payroll" out to build roads. Others were persuaded to take up plots of land and to develop them with a view to future independence. Those who took the latter option were put onto a piece work scheme they worked half the week for the Company's dole, and spent the rest of the week working on their land. This earliest example of a relief system in the colony collapsed with the failure of the New Zealand Company by 1844 to provide the funds to pay the dole promised. (Allan, pp 183-188; 355-363)

${ }^{137}$ Campbell, p. 79

${ }^{138}$ Bassett, Judith, Dark Satanic Mills 1880-1890 in Binney, Bassett \& Olssen, p. 191. Eldred-Grigg (1980), also indicates that there was a reluctance among the politicians to admit to "real" unemployment. (p. 53) 
that, it would be a dangerous principle for this colony to affirm that any man has a right to go to the State and demand relief whenever he pleases. ${ }^{139}$ The poor, if allowed to claim relief he claimed, would become a permanent drain on those colonists who had demonstrated industry, frugality, forethought, and perseverance. ${ }^{140}$

It was consistently ignored that the demand of the unemployed was for work, not welfare. ${ }^{141}$ When charitable organisations and the Government finally reluctantly and slowly responded in the 1880 s to the very real needs of the unemployed, a Christchurch petition from a group of unemployed men stated that they had not come to New Zealand to line up in soup kitchens; they wanted work, not charity. ${ }^{142}$ Many were ashamed to disclose their poverty, especially faced with strong social pressure against accepting relief. ${ }^{143}$ Confronted with accusations of malingering, ${ }^{144}$ suggestions that the police should be encouraged to look into the moral character of those applying for relief in case they inadvertently encourage the thriftless and lazy, ${ }^{145}$ and society's condemnatory

\footnotetext{
139 Cited in Hamer, in Chapman \& Sinclair, p. 81

140 ibid
}

${ }^{141}$ Tennant, Margaret, Paupers and Providers. Charitable Aid in New Zealand, p. 186. Tennant's book is a comprehensive study of the whole question of relief and aid during the nineteenth and early twentieth centuries.

${ }^{142}$ Cited in Campbell, p. 72

143 ibid, p. 73

144 Belich cites Arthur Thomson as saying, In New Zealand those only are poor who from sickness cannot, or from idleness, and intemperance will not work. (p. 309)

145 Olssen,(1984), p. 109 
attitudes towards those loafers who were unemployed, ${ }^{146}$ is it any wonder that many of those desperately in need of relief took to the roads to search for work? The search for work was not just within New Zealand, as in the latter part of the 1880 s numerous men left the country in what can be only described as a mass exodus of workers. A considerable number went to the Australian Colony of Victoria that presumably must have responded favourably to the following petition from one group of unemployed in Dunedin, which illustrates their desperation: -

We the undersigned, being in every sense of the word genuine working men, able and anxious to obtain employment, have been miserably betrayed by false representations of New Zealand by emigration agents, lectures and printed pamphlets, threw up situations, broke up homes and left loving friends, are now facing the bitter reality of parading the streets, hungry and ill-shod, with no prospect of a better future, do humbly beseech you to take into favourable consideration our wretched lot, and afford us the opportunity of coming across to your prosperous and protected country, where we may live and not starve. ${ }^{147}$

Those who did not take to the roads frequently agreed to low wages in appalling conditions. Men took boys' wages, girls worked for nothing simply to get training at a job and were then often laid off when they had mastered the work, while women went into factories and competed against their children for positions. ${ }^{148}$ As Sutch points out, the English system of sweating took little re-learning, ${ }^{149}$ but when the Presbyterian minister, Rutherford Waddell, drew the public's attention to the conditions that numerous women in Dunedin tailoring and dressmaking factories were working under,

146 Tennant, p. 184

147 Cited in Salmond, J. D., New Zealand Labour's Pioneering Days, p. 31

148 Sutch, (1966), pp. 65-6

149 ibid, p. 66 
there was considerable shock among the colonists who thought they had escaped such issues. The Otago Daily Times took up the challenge and began to investigate Waddell's claims, finding one widow whom they described as no drunken idler but well educated, for she read the poetry of John Milton, ${ }^{150}$ but who nevertheless, for twelve hours work received only between two shillings, and two shillings and sixpence. The investigating reporter went on to divulge: -

...that in spite of the fact that they faced a future of unremitting toil and poverty, the majority of the workers accepted their lot in the spirit of fatalistic resignation. ${ }^{151}$

Demonstrated by these attitudes is a tenacious belief among the workers in the colony that no kind of work was a disgrace. ${ }^{152}$ It was better to work for very little than be branded as a "loafer." Poverty however, was an inescapable condition for many workers no matter how industrious and frugal they might be. The blame for their poverty was always placed on them, the belief generally being that they must be spendthrift or have drunk their wages away. ${ }^{153}$ Poverty was regarded as a personal weakness, ${ }^{154}$ even punishment for moral laziness. ${ }^{155}$ Robert Stout's opinions on poverty, for example, were not uncommon. He is quoted as having remarked: -

${ }^{150}$ Cited in Olssen, Erik, (1971), The Sweating Agitation, New Zealand's Heritage, p. 1496

${ }^{151}$ McClintock, p. 721

152 Elkington, E. Way, Adrift in new Zealand, p. 17

153 Eldred-Grigg, (1982), p. 60

154 Hamer, in Chapman \& Sinclair, p. 82

155 Eldred-Grigg, (1982), p. 131 
As long as we find people selfish and ignorant, imprudent and wasteful, poverty will exist as a punishment for their selfishness, ignorance, wastefulness and imprudence. ${ }^{156}$

The individual could improve their own lot only through self-improvement, ${ }^{157}$ and an adoption of moral values such as industry, thrift and perseverance. The fact that there was no work available, or only badly paid work, was conveniently ignored by both politicians and the wealthier citizens of the colony. This blindness to the situation is reflected in the following passage from Our New Zealand Cousins published in 1887 at the height of the economic depression: -

To active, intelligent artisans, and workers who have no capital but their own stout hearts and strong, willing limbs, these colonies present a field for their enterprise, such as nowhere on earth. We have no room for the intemperate idler, the loafer, or incompetent, chicken-hearted, slovenly shirker. We have enow of these, God wot, already, but there is work out here for every willing, capable, self-respecting man... ${ }^{158}$

With the exception of Rutherford Waddell it appears few churchmen spoke out against the injustices confronting those settlers who found themselves in economic difficulties.

156 Cited in Hamer, in Chapman \& Sinclair, p. 82

157 The dominant strand of self-help/improvement ideology which was found in Victorian Britain in the writings of Samuel Smiles was according to Fairburn (1995), also found in New Zealand. The same ideas as mooted by Smiles and the self-improvement literature back in the homeland were conveyed through the numerous advice books for immigrants. (p. 165) Fairburn also asserts that the colonial press was saturated with self-help ideology (p. 209) which was manifested through articles on New Zealand as a great place for those who were thrifty and industrious, damning accounts about vagrants and drunks, and reports condemning the "undeserving poor". Robert Stout was a great champion of the notion of self-improvement. (Hamer, in Chapman \& Sinclair, p. 83)

${ }^{158}$ Inglis, James, Our New Zealand Cousins, pp. 298-9 
Waddell's part in the sweating controversy of the 1880 s is well recorded ${ }^{159}$ but the reluctant reaction of his colleagues on the Otago Presbyterian Synod shows that even the clergy and elders of the Church, were well indoctrinated with the belief that poverty was a punishment for personal failings. A Professor Dunlop is quoted as saying that the problem of sweating faced by the poverty-stricken women of Dunedin, lay with the immorality of the husbands, who were drunken and would not work ${ }^{160}$ To be fair the Synod did finally agree to deplore the existence of the "Sweating System" in the Colony ${ }^{161}$ but only after Waddell had succeeded in overcoming the reluctance of the older members of the Synod to support his resolution.

Yet it is doubtful that many of them would have disagreed with Waddell's conviction that work was sacred, ${ }^{162}$ for traditionally the Free Church of Scotland, which was behind the settlement of Otago, preached frugality and industry. ${ }^{163}$ The Free Church, the result of the Disruption in Scotland in 1843, attracted a rising middle class which fused

159 For example Breward, Ian, Rutherford Waddell - A Christian in the World, New Zealand's Heritage, pp 1491-1495; Olssen (!971); and several dissertations from Otago University students mentioned in the bibliography of Eyles, R. J., Rutherford Waddell: Man and Parish. A particularly good account of the whole sweating scandal can be found in Salmond, pp. 50-9

${ }^{160}$ Olssen, (1971), p. 1497

${ }^{161}$ Cited in Davidson, Allan K., \& Lineham, Peter, Transplanted Christianity, p. 229

162 A report in the St Andrew's Parish Monthly, in June 1886, spelled out that Waddell did not believe in a distinction between the secular and the sacred, and that he regarded work as sacred. (Cited in Eyles, p. 4.) McClintock in his history of Otago also makes this point about Waddell's beliefs. (p. 719). Another Presbyterian minister of a similar era who believed in human labour being vested with divine dignity, was the Reverend D. M. Stuart. His theology is discussed in Ross, C. Stuart, Rev., Life and Times of D. M. Stuart.

${ }^{163}$ Olssen, (1984), p. 33 
Calvinist theology and laissez-faire economics into what Olssen has described as a spiritually corrosive ideology $y^{164}$ in which capitalism and Christianity supported each other. The Reverend Thomas Burns, one of the founders of the Otago settlement, was himself a capitalist, and was for some years one of the largest employers in the new settlement. ${ }^{165} \mathrm{He}$ is even recorded giving advice to intending capitalist emigrants. ${ }^{166}$ This is surely a surprising illustration of Olssen's point, although others can be named ${ }^{167}$ who equally merged their faith with their capitalist aims. ${ }^{168}$

The immigrants who came to Otago were, according to Captain Cargill another of the settlement's founders, imbued with the principles and habits of Scotch piety. ${ }^{169}$ Many of the immigrant Free Church members have been described as evangelical, ${ }^{170}$ and one

164 ibid, p. 48

${ }^{165}$ Merrington, E. N., A Great Coloniser. Reverend Thomas Burns, p. 173

166 Burns, T. Rev., Early Otago and Genesis of Dunedin, published with no page numbers.

${ }^{167}$ Olssen, (1984), mentions James Macandrew and James Cargill, p. 48

168 An Australian study by Kevin Blackburn, The Protestant Work Ethic and the Australian Mercantile Elite, 1880-1914, The Journal of Religious History, Vol. 21. No. 2, June, 1997, pp 193-208, discusses the evidence for the work ethic among Presbyterian, Wesleyan and Anglican businessmen. All three denominations in Australia preached a work ethic which included an admiration for material success, and a contempt for laziness. Work was regraded as a righteous act, a virtue. Wealth was the result of one's industry and thrift, and strength of character. Blackmore does point out however, that gradually the religious components of the Protestant Work Ethic were secularized among the Australian mercantile elite, to be replaced with the concept of economic individualism.

${ }^{169}$ Cited in Olssen, (1984), p. 34

170 Chapman, Robert, Fiction and the Social Pattern, in Curnow, W., Essays on New Zealand Literature, p. 79, states that in its origins the Free Church in Scotland had tended to attract evangelical elements which were then sent to New Zealand with the settlers. 
can but assume that they were therefore familiar with the principles of the "gospel of work." Certainly it appears that they believed that success was God's reward for virtue, ${ }^{171}$ and that weaknesses like shiftlessness and intemperance would be punished through the scourge of poverty. ${ }^{172}$ Nevertheless, not all those who were economically successful found themselves in favour with the Church as demonstrated by this comment in the Jubilee Memorial of the Otago Synod. The Reverend James Chisholm wrote: -

It is loathsome to think of the elevations some people aspire to. They will perch on a heap of reeking compost made up of prejudice and vanity, with the iridescent scum of the brown wash of conceit all about them, if only they may seem in their own eyes to be a little higher than their neighbours. Such ambitions are altogether alien to Presbyterianism. It has always been willing to tread the solid earth with hob-nailed boots, if need be, and do rough work with honest hands, if thereby it might serve its generation in producing true manhood and furthering the Kingdom of God on the earth. ${ }^{173}$

The long Protestant legacy of opposition to greed, acquisitiveness and worldliness appears to re-emerge with such declarations.

It was not only the Presbyterians with their Calvinist background who preached the sacredness of work. The Anglicans too spoke of these virtues, Bishop Cowie of

171 ibid, p. 48. This belief in success as divine reward was not limited to the Otago Presbyterians. Crawford, Scott, A. G. M., The Inter-Relationship of Recreation and Religion in a Colonial Environment, Journal of the New Zealand Federation of Historical Societies, 2(4), September, 1986, p. 16, states that: - The puritan ethic, supported within and outside the church, was perceived as the predominant route to success in nineteenth century New Zealand. Eldred-Grigg, in his book The Rich, describes the achievements of one John Harding (denomination not mentioned) who arrived in Wellington with very little and by 1845 was a rising merchant. Harding is cited as saying I desire to Prais God regarding his success, and felt that he had won God's blessing on his thriving little business. (p. 39)

${ }^{172}$ As reflected in Professor Dunlop's assertions at the time of the sweating controversy, Olssen, (1971), p.1497; Olssen (1984) also indicates this, p. 54

${ }^{173}$ Chisholm, James, Rev., Fifty Years Syne, p. 87 
Auckland describing at length in his book Our Last Year in New Zealand, the example of one Mr Dobbie from Whangerei whose indefatigable industry and thoroughness were a stimulus to the young people of the country. ${ }^{174}$ Like the Presbyterian James Chisholm, however, the Anglican layman Robert Godley, was also critical of those who devoted too much time to the sole purpose of making money, and providing the body with creature comforts. ${ }^{175}$ His concern centred on the fear that too much work would exclude pursuits which tend to cultivate the intellect and purify the heart, ${ }^{176}$ or put another way, it would detract from the religious side of the new colony. ${ }^{177}$ Nonetheless, Godley, like his Presbyterian counterparts, encouraged work, and valued its nobleness. ${ }^{178}$

Modern historians such as Sinclair ${ }^{179}$ and Belich ${ }^{180}$ recognise that the evangelical, "puritan" Protestant churches influenced attitudes in pioneer New Zealand despite the fact that many emigrated for purely secular reasons. The work ethic, as Belich puts it, had perhaps percolated up with moral and religious evangelism ${ }^{181}$ of nineteenth century

174 Cowie, William Gordon, Our Last Year in New Zealand, pp. 262-3

175 Godley, p. 105

176 ibid

177 Purchas, H. T., Bishop Harper and the Canterbury Settlement, p. 41

178 The Christian temperance movement of late nineteenth century New Zealand, also championed the sacredness of work, blaming alcohol for undermining good work habits. Phillips charges the prohibition movement with spreading the Protestant ethic, especially the virtues of self-restraint and delayed gratification. (p. 61-2)

179 Sinclair, (1980), p. 105

${ }^{180}$ Belich, p. 326

181 ibid 
Britain, ready to surface in New Zealand immigrants as a middle class virtue. This seems to be more than a likelihood, but rather, an actuality. While much of the evidence is of a secular nature, the consistent values of industry, thrift, perseverance, and self-reliance advocated in the contemporary literature, indicate an ideology based on the gospel of work. These values appear to have been common to working class labourers as well as merchants and landowners, and to both church and non-church members. The notion of wealth as reward for virtuous living seems to have also been a recurring theme among both religious and secular communities. ${ }^{182}$

Regardless of the strength of the work ethic in nineteenth century New Zealand by the end of the period it was reluctantly recognised that Utopia had not been established in the colony. Despite the industriousness of its settlers, and the investment of capital, New Zealand was not as prosperous as many had imagined it would be. Some like Robert Stout blamed this on a lack of thrift, accusing settlers of being too wasteful with their hard earned money. ${ }^{183}$ But even as he censured his country people Stout had hopes for the future. With a healthy climate, he said,

..with strength and thrift and an ingrained respect for law and order, why should not the race, surrounded by the lavish gifts of nature, become a noble one? ${ }^{184}$

182 The religious perceptions about success and reward have already been touched upon. Fairburn, (1989) however, points to a belief collectively held in the general community, that acquisition of property through the aid of the State in the 1890 s was due to the individual's merit rather than a government policy (p. 265). Sinclair (1986) declared that Wealth was a sign of success and a cause for national pride. (p. 13)

183 Stout, Robert, New Zealand, p. 24

184 ibid, p. 176 
A national self-image based on the work ethic was consequently carried on into the twentieth century and emerged with vigour in the 1930 s with the Great Depression. 


\section{CHAPTER 4}

\section{"No pay without work " - the maxim of the Great Depression}

The Victorian Gospel of work was never illustrated so graphically as an integral part of the New Zealand collective unconscious as it was in the Great Depression of the 1930s. In a country led by those born into the Victorian age, the dictum of "no pay without work" was rooted in an understanding of work that was no longer relevant in the light of an international economic depression. The insistence, however, of Prime Minister G. W. Forbes in 1931, that no person in New Zealand should receive a "dole," on the basis that it was demoralising to those who accepted it, ${ }^{1}$ not only shaped the Government's strategy on unemployment relief but became the foundation of the misery that followed. ${ }^{2}$

The fact was that the relief work created for the unemployed was as demoralising as Forbes believed the dole to be, ${ }^{3}$ but a strong belief in the virtues and values of a previous age made working for sustenance of some kind imperative in the minds of many New Zealanders, for it was not just the politicians who embraced the work ethic of the nineteenth century. Poet Allen Curnow wrote in 1933:-

They gave your hands a grubbing tool

${ }^{1}$ Frequent references are found concerning this decision by Forbes. e.g. Morrell, W. P. \& Hall, D. O. W., A History of new Zealand Life, p. 248; Bassett, Michael, (1967), The Depression of the Thirties, p. 12; Noonan, Rosslyn, George Forbes: The Inflexible Conservative, in New Zealand's Heritage, p. 2285. It must be noted that Forbes was not alone in his stand. Other well known politicians of the era, such as Coates, Stewart, and Hamilton, had similar viewpoints.

${ }^{2}$ Bardsley, Dianne, \& Burr, Mike, The Mindless Enemy, p. 38

${ }^{3}$ Morrell \& Hall, p. 248; Noonan, p. 2285 
and you have learnt to use the thing: you thought, a man's a bloody fool who starves when work is offering. ${ }^{4}$

The ethic so firmly ingrained in the mind set of the New Zealander meant that despite the poor pay, and the shocking conditions many endured while on relief work, it was better to acquiesce to the Government's policy, than to lose self respect and watch families starve. To work was imperative for one's self-esteem.

The primary problem of the Depression years was the ill-preparedness of the Government to deal with a long term economic depression and the unemployment that resulted. Despite signs in the early twenties, the vibrations of the economy had been regarded, not as portents, but as a result of the last gales from the postwar depression. ${ }^{5}$ The worldwide phenomenon that was to become the Great Depression seemingly crept up on New Zealand while the people looked for prosperity and material success, and tried to ignore the falling export prices of primary produce. The general belief was that New Zealand remained a country where a man can go about and get work, and stop when he wants to, and make money when he needs it. ${ }^{6}$ Immigration was still encouraged - some 40,000 individuals were lured to New Zealand between 1918-1927 enticed by glowing pictures depicting scenes of Dominions abroad, displaying acres and acres under tillage. ${ }^{7}$

${ }^{4}$ Curnow, Allen, On Relief, Collected Poems 1933-1973, p. 21

5 Sinclair, (1980), p. 255

${ }^{6}$ Mulgan, John, (1972), Man Alone, p. 36

${ }^{7}$ Fraser, George, Ungrateful People, p. 12, citing a letter written by a Dominic Nolan, a British swagman who died in the Waikato region in 1927 (?), having come to New 
Despite the ostrich-like stance of the general population, the unexpected sharp recession of 1921 had led to growing concerns in Government circles about suddenly increasing levels of unemployment. The Arbitration Court had put a hasty hold on wages, senior public servants and government ministers had taken a wage cut of $10 \%$, and local authorities had been asked to help with providing jobs for those out of work. ${ }^{8}$ Assuming that the recession was simply a temporary down turn in the economy, no long term plans were made by the Government to deal with unemployment, and attempts by the Labour party to encourage some sort of unemployment insurance similar to that already established in Britain, met with firm resistance. Deluded into believing that New Zealand was still a land of boundless opportunities, ${ }^{9}$ the Government was reluctant to take any real responsibility for those unable to find work. Unemployment insurance it believed would only encourage the lazy to become a burden on the state. ${ }^{10}$ A nineteenth century mind set kept the ruling parties from recognising that work and unemployment patterns were changing, and that traditional responses were no longer relevant.

In 1926 however, there was another sharp fall in the prices of the country's primary products. Unemployment escalated. The mood of the country began to change. As the

Zealand with high hopes. In 1940 Frank Sargeson published Big Ben, a fictional story about a British immigrant who had decided to try his luck in New Zealand. And his luck had been pretty good until like so many others he'd got hit slap-bang by the slump. (The Stories of Frank Sargeson, 1982, p. 127) While this story is fictional it gives an accurate picture of the disillusionment of those who immigrated expecting to find the country of the dazzling advertisements which had seduced so many poor victims. (Citing further from Dominic Nolan's letter.)

${ }^{8}$ Bassett, Michael, (1995), Coates of Kaipara, p. 71

${ }^{9}$ Bassett, (1967), p. 10

10 ibid 
numbers of unemployed began to soar in the cities as well as the country, ${ }^{11}$ those unable to find work began to get restless. In Auckland, in May 1926, a large deputation met with the then Prime Minister, J. G. Coates. While reported as showing some sympathy he is cited as saying: -

The men must be prepared to go where the work will be found for them. We have to get the men out of the city. They may have to live in tents, but we have done all that. There will be no molly-coddling. ${ }^{12}$

Nonetheless, the Government and local bodies did take steps, inadequate though they may have been, to provide employment. An Act was rushed through Parliament that gave local authorities the power to borrow money to provide relief works for unemployed men, ${ }^{13}$ and according to the 1930 New Zealand Official Year Book, the state itself provided direct employment as far as possible. ${ }^{14}$ The reality was that the Public Works Department as one writer has commented, became the dumping ground for the unemployed. ${ }^{15}$

These measures did not stop the climbing unemployment figures, and, by the time of the 1928 election, public disillusionment with the ruling party's ineffectiveness was to lead to a resounding set back for the Coates' Government. Comments from some cabinet members had certainly not endeared the Government to the unemployed. Coates himself

\footnotetext{
${ }^{11}$ Unemployment had generally tended to be seasonal, and largely based in rural areas.

${ }^{12}$ Fraser, p. 9

131926 Local authorities Empowering (Relief of Unemployment) Act

${ }^{14}$ New Zealand Official Year Book 1930, p. 892

${ }^{15}$ Bassett, (1995), p. 128
} 
had indicated that it was wrong for the unemployed to expect to hang around the neck of the State, ${ }^{16}$ and one of his Minister's had commented that, If the position of the unemployed man was made attractive, no effort was made by men to scratch around and find work for themselves. ${ }^{17}$

Their position it has to be acknowledged, probably reflected a viewpoint common to many New Zealanders, especially those who were still in employment, but despite the common conviction that unemployment and laziness went hand in hand, the issue of work loomed large in people's minds in unprecedented ways. Fear of unemployment, for example, was beginning to infiltrate the thought patterns of New Zealanders, and was played upon in political campaigns. George Fraser, in his book, Ungrateful People, comments: -

1928 was election year, and the question of work was so much in people's minds that even the liquor interests referred to it in their campaign for continuance, using the slogan, "DON'T INCREASE UNEMPLOYMENT...VOTE CONTINUANCE." Underneath an advertisement depicting hundreds of men outside a labour bureau, the text read: 'Would you throw over 20,000 breadwinners out of work? Make no mistake, these people would not be absorbed into other industries. If they could, why do not these other industries absorb the present unemployed - nearly 5,000 in number - the majority of whom are all willing to work? ${ }^{18}$

The growing fear of unemployment however, was largely repressed by a people who preferred to believe that this was not going to be a depression different from any other previously experienced. Economic recession was regarded as a type of natural disaster,

${ }^{16}$ Fraser, p. 13

17 ibid, citing the Hon. Downie Stewart

${ }^{18}$ Fraser, p. 13 
something to be endured until it passed, not an event that could be managed by human intervention. ${ }^{19}$ There was an underlying, misguided optimism -

I knew how tough things were getting by the number of overdue accounts we had, but everyone said that things would take a turn for the better, that they couldn't get any worse. ${ }^{20}$

But they did get worse. A momentary and tentative sign of recovery early in 1929 raised hopes that were to be quickly dashed when it became clear by midyear that New Zealand was heading into deep depression. By the time of the American Wall Street stock market crash in October, unemployment in New Zealand had already risen to 6,264, with no signs of abatement. The Government did not seem able to come up with any palliative schemes to help the situation despite a conference in 1928 to investigate the problems of unemployment facing the country. They're running around like a chook with its head off, ${ }^{21}$ claimed the father of Ruth Park in her autobiography, A Fence Around the Cuckoo.

The Government had nonetheless undertaken in September 1929: -

to find employment within a specified time for all genuinely unemployed, provided they registered at the Government labour bureaux and were willing and able to accept the work offered. ${ }^{22}$

Astonishingly, the 1931 Official Year Book attributed the rise in unemployment by

19 Simpson, Tony, (1990), The Slump, p. 43

${ }^{20}$ McClenaghan, Jack, Travelling Man, p. 61

${ }^{21}$ Park, Ruth, p. 69

${ }^{22}$ New Zealand Official Year Book, 1930, p. 892. The bolding of "genuinely" is mine. 
October 1929, as no doubt largely due to this move, suggesting that the Government's introduction of a comprehensive programme of relief works ${ }^{23}$ had led to increased numbers of registered unemployed.

A truly comprehensive programme, in reality, did not occur until 1930 with the introduction of the Unemployment Act that provided sustenance payments to unemployed adult males. ${ }^{24}$ From the very beginning it was resolved that relief would only be paid to those who worked for it, and a number of schemes were set up to provide work. The Government's determination during this period to balance the books $^{25}$ also meant that any relief paid must not exceed the funds allocated, ${ }^{26}$ and it is

${ }^{23}$ New Zealand Official Year Book, 1931, p. 845

24 There was no sustenance available for unemployed women (despite the existence of many unmarried unemployed women, the reasoning appears to have been that women should have men to provide for them), or Maori males (who were expected to be able to live off the land). Youths under 20 were also not entitled to any sustenance. The money to pay for this sustenance came from a poll tax on all adult males whether working or not, and working women, despite the fact that they were not eligible to receive any payments.

25 The compulsion for governments to balance the budget during the Great Depression was an international phenomena. John A. Garraty in his book The Great Depression comments: -

Belief in sound money and balanced budgets was widespread. Many of those who favoured expanding public works programs and other policies that they believed would stimulate the economy and help people in distress believed at the same time (and usually far more intensely) that belt-tightening and paying the piper were both economically necessary and morally correct. (p. 48)

The New Zealand Government was no different from its counterparts. Tony Simpson's observation bears this out: -

The principle mote in the government eye was the need for a balanced budget. That the deficit required drastic action for immediate reaction was the wellspring of financial orthodoxy in government circles..... Why this consideration should have been so central has never been satisfactorily explained. (p. 43, 1990) 
horrifying to note that the Unemployment Fund had a favourable balance each year of the depression. ${ }^{27}$ The relief schemes set up under the Unemployment Act were as plodding and as lacklustre ${ }^{28}$ as the Prime Minister George Forbes himself. The announcement by Forbes in January 1931, that the unemployed would definitely not be given a "dole" and that there would be no payment without work, led to the hasty cobbling together of the infamous "Scheme 5", in an attempt to provide the appearance of work for the thousands not otherwise employed. ${ }^{29}$ The rationing of work under this scheme, for the receipt of a pitiful amount of relief, was a desperate measure to maintain the Government's insistence of work for all. Hindsight shows the scheme was heartless and futile, but in retrospect it has also been pointed out that the measures introduced in 1931, harsh though they may now seem, were not the acts of evil men but of men who believed in a set of economic rules that were no longer relevant.$^{30}$

Relief schemes or not, unemployment rates soared over the next two years. By October 1933 the official figure was close on 80,000 . Confronted throughout the country with increasingly angry demonstrations in 1932, a frightened Government still determined to maintain its principle of "no pay without work", had established relief camps first for

${ }^{26}$ Oliver, W. H., The Story of New Zealand, p. 183

${ }^{27}$ Sinclair, (1980), p. 258

${ }^{28}$ Simpson, (1990), p. 57, describing Forbes

${ }^{29}$ Bassett, (1995), p. 162

${ }^{30}$ Lee, John A., The Great Depression, in New Zealand's Heritage, (1971), p. 2271. In light of Lee's place in the history of Depression and the Labour party, this is perhaps a surprising defence of the actions of the politicians who were his adversaries in the Thirties. 
single men, but then had widened the criteria to include married men as well. All this did was extend the misery of those without valid work, as increasingly the work provided by the local bodies and central authorities was of little value to the community, and of even less self-worth to the individuals engaged in it.

The Government of this country seems to have withdrawn into a kind of mental euthanasia, Elizabeth McCombs, a Member of Parliament, railed during a Parliamentary debate, in September, 1933. She went on: -

It sits there sublimely satisfied that all is well.....The official figures register eighty thousand unemployed. These figures do not include women. If we include women and youths we find the number is practically double;.... add to those the number of people who are in employment but who are working only half time or part-time, and earning no more than relief rates of pay, and we will find that they total practically as many as the total registered unemployed. ${ }^{31}$

Confronted with these sort of figures, and a lack of available work, there was only one alternative for the Government. Begrudgingly, late in 1933, the Unemployment Board was forced to review the stated policy that no sustenance without work would be granted. At last a "dole" was conceded, although at a slightly lower scale than that given to those on relief work. ${ }^{32}$ The following year sustenance payments were regularised and made permanent - there was finally official recognition that the Government had some responsibility in assisting those unable to find work through no fault of their own.

31 Cited in Rankin, Keith, Unemployment in New Zealand at the Peak of the Great Depression, p. 2. Rankin claims that McComb's figures would have equalled 240,000. His research supports this figure, but he also adds another 240,000 with incomes above zero, but less than one pound per week, at a time when an adequate living wage was in excess of four pound per week. (p. 28)

${ }^{32}$ New Zealand Official Year Book, 1936, p. 648 
Throughout the previous few years however, the plight of the jobless had reached $a$ pitch of desperation little short of complete destitution. ${ }^{33}$ The callousness and inhumanity $^{34}$ of the Coalition Government in its insistence of "no work, no pay," alongside the other drastic retrenchments it had taken to balance the budget ${ }^{35}$ led to its defeat in the 1935 election, and the advent of New Zealand's first Labour dominated parliament. ${ }^{36}$ For many the demise of the Coalition Government was a denunciation of its policies, a punishment for the human misery it was deemed to have caused.

The question has been raised as to whether the social traumas experienced by a considerable proportion of New Zealanders during the Great Depression were as severe as national "mythology" would have us believe. ${ }^{37}$ Detailed accounts of the actual hardship and wretchedness endured by those who were unemployed during the depression may not be plentiful, ${ }^{38}$ but as John A. Lee observed, Each home was so

${ }^{33}$ Oliver, p. 183

${ }^{34}$ ibid

${ }^{35}$ For example, public servants received severe pay cuts, children's entry age into school was raised in an attempt to save teachers' salaries, schools were allowed to fall into disrepair, pensions for the old and disabled were cut. (ibid)

${ }^{36}$ I do not believe that the introduction of the welfare state by the Labour Government in the years following its election in 1935 comes within the realms of this thesis, although attitudes towards those receiving unemployment benefits under the welfare system in later years will be examined further on in the thesis.

${ }^{37}$ Hawke,G. R. The Making of New Zealand, has raised this issue (pp 122-123). Simpson (1990) responds to this suggestion critically (pp 42-43)

38 Tony Simpson's The Sugar Bag Years, (1984), is the best example of a collection of impressions and experiences of the depression, but there are several autobiographies which give excellent accounts of living through those years of the depression. e.g. Ruth Park's A Fence Around the Cuckoo, Mary Findlay's Tooth and Nail, and A. Tremenheere Yorke's The Animals Came First, provide detailed narrative, while others like Janet 
conscious of its own stark misery that nobody set out to make a catalogue of suffering. ${ }^{39}$ For a decade, from the late 1920 s to late 30 s, the depression dominated the consciousness of New Zealanders, ${ }^{40}$ and even once the crisis had passed, there persisted several years of convalescence that were just as wretched for many people. ${ }^{41}$ Mythology it has been pointed out, can be defined as a rationalisation of the truths of facts in the patterns established by experience, ${ }^{42}$ and while undoubtedly there was an unevenness of experience, perceptions of the depression became deeply rooted in the psyche of New Zealanders. ${ }^{43}$

Despite the chronic high unemployment there were those who were relatively unscathed by the depression, and whose experiences were those of observers, rather than participants. Jane Garrett, daughter of the artist Christopher Perkins, observed that while the Perkins family was only affected in minor ways, the depression nevertheless

Frame's To the Is-Land, and Frank Sargeson's More Than Enough allude to their experiences of the depression but without the same detail.

39 Lee, (1971), p. 2273

${ }^{40}$ Reid, Ian, Fiction and the Great Depression: Australia and New Zealand 1930-1950, p. 3

${ }^{41}$ ibid

${ }^{42}$ Simpson (1990), p. 43

43 Personal note: I found it fascinating that while researching this chapter, whenever I told people over forty what I was doing I was instantly regaled with stories about the depression that had been related to them by grandparents or parents. My impression is that the "mythology" of the depression is still alive and well. Some of what I have been told relates to what I have learned through my reading, confirming I think that not all the "myths" are exaggerated "fairy tales", while other stories have been distortions of the facts as I have researched them, but with enough truth behind them to bear witness to a mythology equating to Simpson's definition. 
seemed to pervade the atmosphere like a fog. ${ }^{44}$ It was difficult, she wrote, to avoid seeing the effects on those less fortunate.

On my way to and from school I would pass a little group of men wearily scraping up the minute weeds growing in the cracks of the pavement. They did not look like the cheery characters usually to be seen working on the roads; they were very silent and were wearing, not the regulation overalls, but shabby office suits. They were the Unemployed, earning their meagre dole by doing government relief work. Their presence, almost under our windows made the Depression seem more real and more alarming than any number of doleful accounts in the papers. ${ }^{45}$

Bruce Mason in his memoir, End of the Golden Weather, remarked that although he had heard the words "depression" and "relief," as a child he had never related them to his own world that appears to have been relatively untouched by the depression. The hunger of some of his school mates, and the miserable, sickly men trying to sell unwanted goods door-to-door, meant nothing to him. There was Us, safe and solid, warm at night and there was Them - hungry and persistent, but separated from us by an uncrossable gulf. ${ }^{46}$ It was only when Auckland erupted into violence in the 1932 riots that he began to realise what it was like for "Them." The reality was that while some were surviving on the niggardly pittance paid for relief work and charity handouts, there others who were still living comfortably, although maybe less ostentatiously than in more affluent times. ${ }^{47}$ One of those interviewed for Tony Simpson's book, The Sugar

${ }^{44}$ Garrett, Jane, An Artist's Daughter. With Christopher Perkins in New Zealand, $1929-34$, p. 113

45 ibid.

${ }^{46}$ Mason, Bruce, The End of the Golden Weather, p. 46

47 Brooking, Tom, Economic Transformation, in Oliver \& Williams, (eds), p. 248. Brooking comments that there were however, some who continued to live just as 
Bag Years, commented: -

I knew there was a depression on in a vague sort of way, but I was in work so it didn't really affect me much. I knew a few people who were out of work, and it made you a bit more cautious about your own job - getting on with the boss, being careful where you put your feet, that sort of thing. ${ }^{48}$

Others clearly were not so fortunate. It did not matter how industrious you had been, how thrifty, or how successful, the depression showed no deference for those who had espoused a strong work ethic. Even Government policies trying to protect the value of work, attacked the very virtues they were attempting to maintain, by insisting that individuals with savings had to use every penny before they were entitled to any relief, while those who had been spendthrift and had no savings, were entitled to relief payments immediately. ${ }^{49}$ In no way was the depression a respecter of persons. ${ }^{50}$ The depression was in fact: -

a visitation upon the industrious and the thrifty as well as upon the improvident. People who by frugal living had acquired a modest competence, men and women who by good service had advanced themselves to executive positions, folk who had become foremen and forewomen were thrust unemployed into the streets with the skilled and the unskilled rank-and-file worker. ${ }^{51}$

extravagantly as they had before the depression, and also observes (p. 247) that the demand for consumer goods never abated despite the high numbers of unemployed. Bassett (1995) points out that even though wages fell, so did prices. He claims that in 1932 the purchasing power of award wages for those still in work, was the same as it had been in 1928. (p. 175)

48 Simpson, (1984), p. 22

49 ibid, p. 36

${ }^{50}$ Lee, (1971), p. 2273

51 ibid 
The depression was, as one person put it, a great leveller, ${ }^{52}$ and not all those who found themselves doing relief work coped well with the loss of prestige they experienced. Respectability, and middle class aspirations and values were soon worthless if a person was sent to dig drains and clear swamps alongside the unskilled labourer they had once looked down on, and some were unable to accept their loss of status. For example: -

There were a number of people who used to come along in a bowler hat and briefcase and suit and then put on overalls behind the shed somewhere to work, and take off the bowler hat or hang up the suit on a tree or somewhere, where it would be out of the dust. And they would have their lunch in their little briefcase.... [It was] as if they were going to some respectable job, as far as the neighbourhood was concerned, perhaps even as far as their wives and family were concerned. These people really found it degrading to do this kind of work.... as far as they were concerned it was a tragedy. ${ }^{53}$

For some the degradation of having fallen so low on the social scale, and the hopelessness of their situation, was too much. One elderly accountant, for example, working in the relief camp at Kaingaroa, had lost his job and his home, while his family had been reduced to living with relatives. He had nothing left at all except his life, which he got rid of one night. ${ }^{54}$ This was not an isolated incident.

It was not just the professional city workers who suffered from a downward spiral in social status during the depression. While there seems to have been an illusion that rural people fared better because of readier access to food, ${ }^{55}$ the reality is that except for the big pastoralists who did relatively well, the burden of the collapse of export prices fell

52 Simpson, (1984), p. 36

${ }^{53}$ ibid, p. 133

${ }^{54}$ Park, p. 187

${ }_{55}$ Burdon, R. M., (1965), The New Dominion, p. 140 
heavily on farmers. ${ }^{56}$ Hard working farming families who had been the living proof of the Victorian settlers' work ethic, and who had previously been regarded as the backbone of the New Zealand economy, found themselves deeply in debt. ${ }^{57}$ Small farmers in particular, had to face mounting deficits as prices continued to fall, the costs of production exceeded income, and mortgage repayments were increasingly difficult to meet. ${ }^{58}$ Like their city counterparts many farmers were forced to live at a subsistence level during the depression, although they were still better off living on the equivalent of sustenance on their farm than being on relief. ${ }^{59}$

As in the previous century there was one group who were prepared to take to the country roads in search of work. Farmers, some barely managing themselves, were certainly not in a position to provide work for those who took to the swag in numbers previously unseen, but nevertheless there were some charitable householders who took it upon themselves to at least provide meals and overnight shelter. ${ }^{60}$ Going "on the swag" was usually a move of desperation rather than lifestyle choice, an often rash and

${ }^{56}$ Brooking, in Oliver \& Williams, (eds), p. 248

${ }^{57}$ Lee, (1971), claims $50 \%$ of farmers declared bankruptcy during the depression, p. 2274

58 The anguish of watching farms under threat of foreclosure during this time is recorded in two poems by Dennis Glover, Root, and Crop, and Stone, and The Magpies. Illustrated in both poems is the desperation of working hard only to see the proceeds being swallowed by the mortgage men. ( The Wind and the Sand 1934-44, pp 22-23; 29) 59 Lee, (1971), p. 2274

${ }^{60}$ Burdon, (1965), p. 140. Burdon in Note 3 (also on p. 140) tells of one farmer's wife who gave meals to at least 42 swaggers of just one winter month of 1933 . Elsewhere, Ruth Park observes that whereas once maybe eight or nine swaggers might have knocked on the door in a month, during the early depression it went up to at least twenty a month. (Park, p. 69) 
ill-considered move by city or town dwellers who believed that if work would not come to them, then they would go and search it out. ${ }^{61}$ Frequently not fitted for a life on the road, ${ }^{62}$ their decision to take to the road to look for work was based on a simple need to eat and survive, ${ }^{63}$ and was maybe sometimes impetuous and unplanned. A. R. D. Fairburn's poem My Man's Gone Now reflects something of this: -
My man's gone now. He had to go.
He couldn't find no work around this town.
Not for ages. Used his wages.
Got up this morning - and he was gone.
Morning sunshine. The rooster crows.
Along the highway walking to where, goodness knows.
Where's John sleeping? How's he keeping?
When will he take the homeward road? ${ }^{64}$

Unable to receive relief work if they were under twenty, some young men who had left school to face a life of unemployment, also took to the swag. An article written in 1932 by a Wairarapa settler about boy swaggers, illustrated the predicament of these young men: -

They were both under twenty... and therefore ineligible to take advantage of any of the Government's unemployment schemes..

61 Bardsley \& Burr, p. 24

62 Park, p. 28, asserts that some of the swaggers spoke like educated professional men

${ }^{63}$ Bardsley \& Burr, p. 25

64 ibid, p. 26, citing Fairburn, A. R. D. Another New Zealand poet to write a poem dedicated to swaggers was R. A. K. Mason. In his book of verse This Dark Will Lighten. Selected Poems 1923-41, the poem On the Swag illustrates the impatience of some towards the swaggers -Oh curse that old lag here again... - and the charity (and its motivation) shown by others - for this is the Christ. (p. xx) 
[The younger boy, 18] was willing to do any kind of work, but nobody seemed to want him.

They were both vague as to what or who was to blame for their plight. There was no work that they knew of. The Depression, whatever was the cause of that, was to blame they supposed. ${ }^{65}$

The writer of the article went on to ask: -

What kind of a social system have we that compels these youths to tramp the country begging for sustenance? In the bloom of their young manhood, intelligent and able-bodied and eager for work, they find themselves unwanted in their own country. ${ }^{66}$

Had these young men been eligible for relief would their eagerness for work have been sustained? Faced with the necessity to create work in order to obtain the subsidies to pay relief workers, harassed local bodies were forced into concocting jobs that would at least give the workers a semblance of an occupation. ${ }^{67}$ Much of the work was clearly unnecessary or even worthless, but with the Government's insistence that it would not pay relief without reciprocal work, the local authorities had little choice but to be highly inventive in devising jobs for the registered unemployed. The schemes were unpopular with both the public who had to pay for them through taxation, and the unemployed who were set to work on futile tasks, but given the Government's stance, there were no alternative options.

${ }^{65}$ Cited in Bardsley \& Burr, p. 27. The article was entitled "Our Boy Swaggers", and appeared in the New Zealand Free Lance Weekly Journal.

${ }^{66}$ ibid. Emphasis mine.

${ }^{67}$ Burdon, (1965), p. 140; Simpson, (1990), p. 64 
The absurdity of much of the work is well illustrated in both fact and fiction alike.

Fact:- We were put to digging a ditch, but nobody knew what it was for or where it was going to. Nobody seemed to know how deep it had to be, so we just stayed in the one place and kept digging until someone came along and moved us on. It was a complete farce, but we were getting paid, and that was all that mattered $^{68}$

Fiction:- I was working on a relief scheme; three days a week I was filling in and digging up again a piece of land in Hataitai. It was supposed to be a playing field....They took great care to get the surface microscopically level and true it took them and us months. Then they would decide to lower the whole thing six inches or so. It gave us work of course. ${ }^{69}$

Absurd or not, the tasks set provided work and pay. Without work, there was no pay, and the person who had found themselves unemployed had no value. Demoralised and depressed already because of unemployment, the relief workers were willing to do whatever they were told if it gave them the guise of working respectability. Ruth Park describes her father going off to a relief camp at Kaingaroa almost with excitement, because it meant a regular job and self-respect again, even if the pay was shocking and the conditions were for slaves. ${ }^{70}$

The camps that were established in $1932,{ }^{71}$ largely as a panicked response to the riots

68 Simpson, (1984), p. 39. Emphasis mine.

69 Gilbert, G. R., A Girl With Ambition, in Davin, D. M., (ed), New Zealand Short Stories (First Series),p. 160. Fiction in this instance was based on fact. The emphasis on the last sentence is mine.

${ }^{70}$ Park, p. 184

71 There appears to be some question as to when the relief camps were actually first established. Burdon (1965, p. 139) mentions September 1931, as does a report in The Scrim-Lee Papers(p. 28) The New Zealand Official Year Book, 1933, (p. 610) however, states the camps were established in 1932, and the very useful Appendix 4 in The Scrim- 
among the unemployed, were as cruel a ploy as any Government, through ignorance and desperation, could devise. ${ }^{72}$ Often located in isolated areas, the camps provided work of a hard physical nature, and living conditions seldom seen since pioneer days. Officially the Unemployment Board described the camps as places where single men are employed in improving access to the backblocks, scrub-cutting, drainage, and other work of a productive nature, ${ }^{73}$ but they ignored the horrendous living conditions. Critical commentators of the time compared the relief camps with prison camps, pointing out that prisoners in reality had better conditions than the unemployed, and only a little less freedom. ${ }^{74}$ Theoretically it might be said that the unemployed did not have to agree to go to work in the camps if conditions were that bad, but the fact was that they had no real choice - if they refused to go to the camps they were given no more relief. ${ }^{75}$

Lee Papers agrees with this. Tony Simpson (1990) seems to imply that the camps were established in 1932 as a response to the riots (p. 65), but in The Sugar Bag Years (1984) he mentions 1933 (p. 15). There appears to be some confusion but I suspect that the Official Year Book is probably correct as it is after all an "official" Government document - unless there were more than two stages of establishment of such camps, that is, camps in 1931 for single men, followed by more camps in 1932 for single and married men. John A. Lee (1971), in his article The Great Depression states that after the riots of 1932 the Government opened more camps (p. 2273), which seems to support this theory. This may all seem a little irrelevant but I believe it is important in that if the majority of the camps were a response to the riots of ' 32 , then they can literally be seen as a punishment against the unemployed for daring to protest about their position. Secondly, by sending unemployed men to isolated places where they could not be so easily seen, the Government was basically denying the existence of a problem.

${ }^{72}$ Park, p. 184

${ }^{73}$ New Zealand Official Year Book, 1933, p. 610

74 Scrimgeour, C. G., Lee, John A., \& Simpson, Tony, The Scrim-Lee Papers, p. 28; Edwards, Jim, Break Down These Bars, p. 85

${ }^{75}$ Burdon, (1965), p. 139; Simpson (1990), p. 65 
Considering the conditions of the relief camps, it is astonishing that any sort of work ethic survived in tact among the men banished from their homes and families. But whether they were draining swamps, building roads, or planting sandhills with maram grass, or frozen, volcanic plains with a forest, and regardless of conditions, they worked. Whatever their social background, they worked side by side, and if fiction writing is to be given any credence, there grew up between them a comradeship based on mutual hardship. ${ }^{76}$ It has been stated that men on relief were subject to a crushing burden of fear, insecurity, anxiety and helplessness, ${ }^{77}$ but nevertheless there was a determination to survive undergirding all that negativity. Charles Stanley wrote for the New Zealand Free Lance,

We are George Forbes's army,

The Unemployed are we;

He says the country's suff'ring

Financial stringency.

And so he's dumped us all down here,

And giv'n us spades and picks,

And in a lucky week we make

As much as seven and six.....

We've got bare food and shelter,

And precious little more;

At times we almost envy

The slaves of days of yore.

But we're not going to whimper,

We'll fight on, to a man,

And if we can't be happy, be

As happy as we can. ${ }^{78}$

${ }^{76}$ McClenaghan, p. 62; Sargeson, Frank, The Stories of Frank Sargeson, (1982 edn), pp. 112-113, in A Man and his Wife

${ }^{77}$ Bardsley \& Burr, p. 40

${ }^{78}$ Cited in Bardsley \& Burr, p. 43. Stanley's poem is entitled Song of the Single Camp. 
In comparison to the establishment of work camps, one seemingly positive move by the Government in 1932-33 was to encourage some relief workers to become part of a small farm scheme. The theory was that granting allotments of land to unemployed workers would help relieve unemployment, and also provide a supply of seasonal workers for established neighbouring farmers. ${ }^{79}$ The land initially would be owned by the Government with the proviso that when the economy improved, the worker would be entitled to purchase the land. ${ }^{80}$ Given the Government's strong conviction about the importance of work, it seems likely that the motive behind the scheme was to help instill, or preserve, the work ethic, but it has been suggested that while this may have appeared to be simply a worthy scheme to assist unemployed men to become self-supporting, it was also a way to make the unemployed less visible statistically, and to keep them out of the cities where they were likely to cause trouble. ${ }^{81}$

Perhaps the surprising thing is that the measures taken by the Coalition Government after the 1932 riots, did not lead to further trouble. While there were complaints about conditions in the relief camps, the protests were peaceful, and if there were any grievances among those on the small farm scheme, they appear to have been kept within the farming community. ${ }^{82}$ Although Prime Minister George Forbes chose to deny that

79 New Zealand Official Year Book, 1933, p. 610

${ }^{80}$ Yorke, p. 51

${ }^{81}$ Garraty, pp. 82-3.

82 Yorke, p. 132, observes that those on the small farm scheme received handouts as being little more than a political sop, when in actuality what they wanted were jobs that paid wages. However she does not mention any real grievances against the Government regarding the scheme itself. 
the riots in various New Zealand cities were genuine protests by the unemployed, blaming instead a lowless minority or Communist agitators, ${ }^{83}$ the reality was that the unemployed, and those fearing unemployment, had reached breaking point in the face of continued Government retrenchment. Trouble at that point in time was inevitable. Having already taken pay cuts, public servants were being asked to agree to a further reduction in wages. Hungry city people were being asked to accept the Government's refusal to provide transport for meat promised free by farmers. Unemployed people were being asked to tolerate petty bureaucrats prying into their private lives to ascertain their right to things the Government had already granted them. ${ }^{84}$ It only needed the insensitivity and stupidity of a few individuals to act as touchwood, and for the conflagration of frustration to blaze out of control. Normally quiet citizens, respectable middle class people as well as the unskilled and unemployed, marched, sang, shouted, and raved. ${ }^{85}$ The hysteria that had been just under the surface for some time erupted. ${ }^{86}$

In Dunedin it was the conservatism of the mayoress which acted as the touchwood. Her insistence that each person applying for rations from the mayor's supply depot must have the merits of their case investigated, ${ }^{87}$ suggests that she was operating from a Victorian world view of the "deserving" and "undeserving" poor that had no place in the Depression of the thirties. In Auckland it was largely fear that kindled the riot; fear

83 Richardson, Len, Parties and Political Change, in Oliver \& Williams, (eds), p. 224

${ }^{84}$ Edwards, Jim, p. 40

85 ibid.

${ }^{86}$ Scrimgeour et al, p. 24

${ }^{87}$ Burdon (1965), p. 143 
generated by a mob teeming to a public meeting about unemployment and wage cuts, and the over hasty reaction of one police officer who let his fear get the better of him at a crucial moment. George Fraser comments that: -

Many employed workers tended to look on the unemployed as a group of people quite different from themselves, not out of snobbish superiority, but more out of fear that the bell might one day toll for them too. ${ }^{88}$

Is it not to be wondered at that employed people, even trained policemen, became nervous and reacted when confronted with thousands of marching unemployed men carrying banners with such slogans as Give us our daily bread. Give us the right to work, ${ }^{89}$ and singing Why don't you like other men do? How the hell can we work when there's no work to do. ${ }^{90}$

The mood of the unemployed in those days of April 1932 is well encapsulated in a poem by an anonymous relief worker written at the time.

We shall come, the unemployed,

The disinherited of this earth, We shall come into your temples And your marble halls of mirth.

We shall come as you have made us,

Ragged, lousy, pale and gaunt, You, the House of Have, shall listen

Unto us, the House of Want.

We are measuring the weed-chip gangs

That stretch from coast to coast, We shall come, us, the rightless,

Us, the Godforsaken host.

We shall come in all the madness

Born of hunger, pain and strife,

\footnotetext{
${ }^{88}$ Fraser, p. 46

${ }^{89}$ Edwards, James, Riot 1932, p. 11

90 ibid, p. 16
} 
On our lips the cry for vengeance,

In our souls the lust for life.

We shall swarm as swarmed the locusts

That on Pharaoh's Kingdom fell,

And sling your politicians

And your damned police to hell. ${ }^{91}$

Given this sort of acrimony and hostility it is not surprising that the Government reacted strongly in the days following the riots as the country reeled from its first taste of civil unrest. Faced with law and order issues many people supported the Government policies and lost all sympathy for those out of work, while dreary, pompous editorials in national newspapers demonstrated how far removed many individuals were from the suffering of thousands of ordinary New Zealanders. ${ }^{92}$

What was forgotten, or ignored, by those passing judgment on the protesting unemployed, was that thousands of families and individuals were living in poverty. Borderline starvation was not uncommon, ${ }^{93}$ and while some historians claim that most people probably had enough to eat, ${ }^{94}$ malnutrition was frequent. Described as the mindless enemy, ${ }^{95}$ poverty haunted both those familiar with limited incomes and those who had once been affluent. Occasionally a story would filter into the media about a family found living in what would now be called third world conditions, that would momentarily jerk the public into some kind of horrified reaction before they once again

\footnotetext{
91 Cited in Simpson (1984), p. 147

${ }^{92}$ Fraser, p. 50

93 Burdon, (1965), p. 139

94 Brooking, in Oliver \& Williams, (eds), p. 248

${ }^{95}$ Park, p. 107
} 
turned their backs on the situation. ${ }^{96}$ Many employed people it is true did give to supply depots but it was often with a level of disapproval towards those who were unemployed and needing charity. ${ }^{97}$ Quite likely the fear that they would be next, caused people to close their minds to what was happening or to look the other way. But some expressed their fear and transmitted it to their families. Janet Frame writes: -

The world swept on with its morning, noon, night, and the Great Depression stalked the streets of Oamaru, bringing the "sack" and the "dole" for many and wage cuts for my father, whose voiced fear, communicating itself to us, was of the "sack" and "going bankrupt." 98

The fear was justifiably real, especially for the respectable middle classes who still tended to regard poverty as a sin, a punishment for some misdeed. ${ }^{99}$

Those who experienced the worst poverty were probably the unmarried women. ${ }^{100}$ Not eligible for any relief, whether they had children or not, they had to rely on handouts from charitable institutions. ${ }^{101}$ The reasoning for unmarried women's ineligibility for relief appears to have been based on the Victorian premise that women should be married or taken care of by their family, ignoring the increasing number who had been in employment before the onset of the depression. The destitution and impoverishment faced by unemployed women whose husbands had deserted them or died, maybe leaving

\footnotetext{
96 Simpson (1984), p. 106

97 ibid, p. 105

98 Frame, Janet, To the Is-Land, p. 72

99 Simpson (1984), p.133

${ }^{100}$ Burdon, (1965), p. 140

101 Bardsley \& Burr, p. 102
} 
them with children to support, does not appear to have been considered. Presumably these women had relied on charity before the depression, and could go on doing so. The humiliation of having to depend on charity meant many women accepted positions of virtual servitude in the homes of the employed for little more than their board and keep, ${ }^{102}$ or for a minimum wage and leftover food. ${ }^{103}$ Other women it is claimed spent aimless hours walking the streets searching for nonexistent work, and then sitting in churches or public libraries, ${ }^{104}$ until it was time to return to wherever they had managed to find a room in some charitable organisation's women's hostel.

The Victorian attitudes that kept women in servitude and reliant on charity, and men working in frequently futile relief jobs, were based on the belief that anything for nothing would be instantly exploited by the unscrupulous and feckless poor. ${ }^{105}$ One writer has gone so far as to describe the 1930 Unemployment Act as a piece of Victorian legislation in that it upheld the emphasis on the deserving and undeserving poor. ${ }^{106}$ Certainly the Victorian stance that any sustenance given to the unemployed should never amount to more than the lowest wage available, and that circumstances surrounding the reception of this sustenance should be as unpleasant as possible, ${ }^{107}$ seems to have been

${ }^{102}$ Mary Findlay in her book Tooth and Nail talks of taking such positions.

${ }^{103}$ Lee, John A., (1934) Children of the Poor, p. 89. Although Lee was writing about the $1880 \mathrm{~s}$ depression it was from the perspective of what he was seeing in the $1930 \mathrm{~s}$.

104 Park, p. 108

105 Simpson, (1990), p. 63

${ }^{106}$ Ebbett, Eve, Victoria's Daughters. New Zealand Women of the Thirties, pp. 4 -5

107 Simpson (1990), p. 63 
heeded. There was undoubtedly a nervousness initially about helping those who might be "undeserving cases," and it has been suggested that this became the justification for the Government's inertia in dealing with the question of relief for the unemployed. ${ }^{108}$

It was an outlook allied, in the early stages of the slump, to a prevalent sentiment that the unemployed were men who did not look for work assiduously enough. The popularity of that smug bromide declined as those addicted to it found themselves, in their thousands, out of jobs. At last there was no longer any question that the cause of unemployment was lack of work. Once that was established in public opinion the distinction between deserving and undeserving cases was seen as meaningless. When there were no jobs what was the point of suspecting anyone of not wanting to work? ${ }^{109}$

The politicians however were slower to respond than the public to the realisation that "no pay without work" was becoming an anachronism. A writer for Contemporary New Zealand remarked that the Government, unnerved by the immensity of the problem before it, fell back on New Zealand's puritan and Presbyterian background, ${ }^{110}$ and given that a high proportion of the Coalition Cabinet were Presbyterians, ${ }^{111}$ it seems likely that their solidly grounded work ethic was indeed brought to the fore as they battled to come to terms with the situation they found themselves in.

George Forbes, for instance, was an example of a good South Island Presbyterian farmer, who although he has been described as New Zealand's most improbable

${ }^{108}$ Edwards, Les, Scrim: Radio Rebel in Retrospect, p. 24

109 ibid

${ }^{110}$ Cited in Sutch, W. B., (1941), Poverty and Progress in New Zealand, p. 134

111 Davidson, Allan, 1931-1966 Depression, War, New Life, in McEldowney, Dennis, (ed), Presbyterians in Aotearoa 1840-1990, p. 103 
Premier, ${ }^{112}$ sincerely believed that the values he had learnt as he developed his farm would serve the country well in its time of crisis. Having being brought up to pay his way in his private dealings he also considered this to be the right course in running the country. ${ }^{113}$ His policy on unemployment relief was based on a belief that sustenance without work crushed the individual's morale and moral-fibre, and given that the country supported his policies in the 1931 election, it can be assumed that at that time he actually reflected the opinion of the majority of New Zealanders. ${ }^{114}$

Forbes however, was not the only politician to reflect nineteenth century views. Gordon Coates, who had been Prime Minister of the Reform Government in the mid-1920s, and went on to be Deputy Prime Minister in the Coalition cabinet, while not Presbyterian but Anglican, supported Forbes' convictions regarding relief work. From as early as 1925 , when the unemployment figures were beginning to build, he had made speeches encouraging people to get their coats off and work for New Zealand, ${ }^{115}$ and assured electors that he saw it as his responsibility to ensure there were jobs for all those who wanted to work. ${ }^{116}$ His strong preference, over against paying a dole, was to help the unemployed help themselves, ${ }^{117}$ and in a speech recorded in the Otago Daily Times in

112 Sinclair, (1980), p. 255

113 Noonan, p. 2285

114 ibid, p. 2286

115 Bassett, (1995), p. 94

116 ibid, p. 102

117 Sinclair, (1980), p. 258, points to the fact that the Small Farm scheme belonged to Coates, and was typical of his approach. 
January 1932, he said: -

It is not the Government's job to keep them, but to make the road open for them to help themselves... [People should realise that it was only by ]thrift, perseverance and intelligence [ that they would win through. $]^{118}$

A third member of the Coalition Government who deserves a brief mention is Adam Hamilton, whose main claim to fame was the misjudgment he showed as Post Master General in blocking the radio programme by the popular Methodist minister, "Uncle" Colin Scrimgeour prior to the 1935 election. Hamilton had trained for Presbyterian ministry but never been ordained, and one commentator on the period claims that Hamilton's God was a sort of transcendental cost accountant who had risen to omnipotence through long hours of hard work and a supreme grasp of business principles. ${ }^{119}$ Described as the archetypal, quintessential Tory, ${ }^{120}$ Hamilton spent the depression deploring excess spending, and the lack of preparedness of workers for such an event as unemployment, and was one of the MP's who showed considerable anxiety at the thought that the Government might be helping "undeserving" people through relief payments. ${ }^{121}$ He probably agreed with his colleague Stuart, MP for Rangiteku, who is cited as saying, The unemployed are only worth $37 / 6 \mathrm{~d}$ a cartload. ${ }^{122}$

${ }^{118}$ Bassett, (1995), p. 177

119 Edwards, Les, p. 18

${ }^{120}$ ibid

${ }^{121}$ ibid, pp 18, 23

${ }^{122}$ Scrimgeour et al, p. 29 
The views of the leader of the Labour party, Michael Savage, while winning him many supporters, were still founded, to a very considerable extent, on the Victorian work ethic. He may have been instrumental in eventually establishing the welfare state but according to his biographer, Barry Gustafson, he nevertheless believed that to give charity to people who wanted to work was economically unsound and humiliating. ${ }^{123}$ He accordingly spoke out strongly against unemployment, and argued that every person wanting to work had an inherent right to do so, and should therefore be given the chance to do so. ${ }^{124}$ People do not want charity, but the right to work for a decent living, Savage is cited as saying in 1935 prior to the election that made him Prime Minister. ${ }^{125}$

There were a significant number of New Zealanders who in the first instance agreed with Government policies, and the viewpoints of individuals like Coates, Hamilton and Forbes. In the first years of the depression it was not uncommon to hear the unemployed blamed for their own predicament, ${ }^{126}$ and even when the situation had deteriorated further and there were thousands out of work, there were still those who claimed the unemployed were lazy and did not want to work. ${ }^{127}$ Some relief workers were given to understand that they were "bludgers", lucky to be granted work

\footnotetext{
${ }^{123}$ Gustafson, Barry, From the Cradle to the Grave, p. 146

124 ibid

125 ibid, p. 162

${ }^{126}$ Olssen, Erik, Depression and War (1931-1949), in Sinclair, Keith, (ed), (1990), The Oxford Illustrated History of New Zealand, p. 216

127 Davies, Sonja, Bread and Roses, p. 20
} 
placements, and told that they could find their own jobs if they really wanted to work. ${ }^{128}$ That "puritan/Presbyterian" background of many New Zealanders was slow to wane, even in the face of evidence that unemployment was an economic dilemma, not a personal failing. ${ }^{129}$ The pioneering heritage of industriousness as a virtue infiltrated right through society and reared its head in some ugly ways.

There were a lot of unemployed men up on Mount Victoria doing useful things like making scenic walks through the trees and other important capital works. And this old swine of a teacher used to make a special point of pointing out to us men leaning on shovels whenever he saw one. 'This, ' he would say, almost trembling with rage, 'is how the taxpayer's money is being wasted on layabouts who won't help themselves.' ${ }^{130}$

I can remember a woman whose son was going to the Depot and she must have known it. She chucked off one day and said to me, 'Look at them with their sugarbags, fancy going asking for bread.' She had no realisation. ${ }^{131}$

For many of the unemployed these sort of attitudes led to a deep-rooted shame.

Convinced that they were somehow to blame for their situation, some became severely

${ }^{128}$ Bardsley \& Burr, p. 57

${ }^{129}$ Rare studies done during the recovery years after the depression, such as the one done by H. C. D. Somerset, Littledene, show how deeply entrenched the puritan work ethic was, especially in rural areas, where "the most admired virtue was a willingness to work." (p. 29) As far as the farming community was concerned the depression had been caused by "modern laziness", and the only way to recover from the effects of the depression was more work.

${ }^{130}$ Simpson (1984), p. 127

${ }^{131}$ ibid, p. 102. A novel of the era which illustrates the real unpleasantness which could be demonstrated by those indoctrinated with the Victorian work ethic and its values, is Outlaw's Progress by R. M. Burdon(1943). The staunch retired Anglican who set himself up as the watchdog of the community in which he lived, must be one of the nastiest characters I have met in any novel, but I suspect reflects the extreme attitudes of some of the conservatives in New Zealand who never accepted the effects of the depression as a failure of the economic system. 
depressed, ${ }^{132}$ others gradually adopted an attitude of I don't care what happens; things can't get worse. ${ }^{133}$ There were those unemployed who refused to take relief work and charity because of the shame attached to being out of a job, and who would take whatever crumb of work they could find, no matter how demeaning, ${ }^{134}$ and yet others who preferred to starve rather than beg. ${ }^{135}$ One fictional character 's experience probably echoed that of many real people:-

"I just couldn't tell my wife when I got home. She doesn't like hearing things like that and I didn't want her upset. But worst of all was that I felt so ashamed."

"Ashamed of what? You hadn't done anything wrong," said Porteous, indignantly.

"It's hard to explain," said Harvey, " but there were all the people who said I was doing so well, and the church group. I didn't know how I was going to face them."

"You weren't a bloody leper," said Hogan.

"But you don't realise. With the people I mixed with, getting the sack was like being sent to jail. There was a stigma about it."

"Some friends," said Porteous.

"You can't really blame them. In a depression the ones who count are the ones who keep their jobs. They're just that much a cut above anyone else. You can't deny it. ${ }^{\text {"136 }}$

There were a few however, who found a freedom in being unemployed. One of the interviewees in The Sugar Bag Years recollects being told about the sense of festivity in having the burden of work lifted, and the resentment in having to get up each morning

${ }^{132}$ Park, p. 99

133 Sutch, p. 138

134 Simpson (1984), pp 83, 88

135 ibid, p. 106; Lee (1934), pp. 136-137

${ }^{136}$ McClenaghan, pp. 61-62 
to go on relief work. ${ }^{137}$ Frank Sargeson, the author, tells in his autobiography about deliberately registering as unemployed so that he would not have to work full time, and would have time for writing. ${ }^{138}$ Part-time relief work became a pattern for many during the depression, and so long as they had enough to eat, the extra free time became part of their lifestyle. ${ }^{139}$ No doubt these were the individuals who were classed as idlers and bludgers by that portion of the community still strongly bound to the concepts of the work ethic.

It may have been expected that the churches would be among those who remained firmly entrenched in the values of the Victorian gospel of work, but from being agencies of social control which preached obedience, and promised rewards in a later life, they became part of the protest movement against the conditions wrought by the depression and Government polices. Initially the churches proclaimed the moral and spiritual transformation they believed was needed to survive and understand the depression, but as conditions worsened and more and more people became unemployed, a social gospel

${ }^{137}$ Simpson (1984), pp. 130-131

138 Sargeson, Frank, (1975), More Than Enough, pp. 25-72, outlines his time as a relief worker. Studies have shown that the depression years saw a rebirth in New Zealand writing. ( Terry Sturm, New Zealand Poetry and the Depression, in Curnow, Wynstan (ed), Essays on New Zealand Literature, p. 18) The depression experience was used as a basis for many stories and poems, both during the depression years, and for some considerable time afterwards. (Reid, p. 87) The perception of writers who lived through the depression has become an important part of any contemporary study of the period, as shown in particular by Bardsley \& Burr's analysis. (Ironically their excellent study has been prepared as an option for the senior secondary school English syllabus, and will be seen by few. It deserves a wider audience.)

139 Simpson, (1984), p. 193 
began to be declared with a new sense of urgency. ${ }^{140}$ Moral and socio-economic questions were no longer deemed as separate by the churches, and criticism of Government policies became the norm, alongside the more traditional organisation of soup kitchens and relief depots.

Les Edwards in his book on Colin Scrimgeour makes the point that depression times were sternly ecumenical, ${ }^{141}$ and occasions like the 1935 appeal to Government from twelve clergymen of all denominations regarding the national scandal of poverty and malnutrition, ${ }^{142}$ are a graphic illustration of this. But each denomination also responded in its own way. Even the Anglicans, who were not renowned for their radicalism, revealed a political awareness, and in 1935 championed the concept of full employment in support of Labour Party policies. ${ }^{143}$

The Roman Catholic Church probably came to terms with the effects of the depression before many of the Protestant churches because large number of its members were among the working classes, and therefore often the first to be unemployed. ${ }^{144}$ As early as June 1931, the Archbishop and Bishops presented a Pastoral Address, examining the economic crisis. This Pastoral Address criticised those who controlled the international economic system for letting it get out of control, and for allowing its manipulation by

${ }^{140}$ Gibbons, P. J. The Climate of Opinion, in Oliver \& Williams, (eds), p. 322

${ }^{141}$ Edwards, Les, p. 25

${ }^{142}$ Simpson, (1984), p. 16

143 Olssen, in Sinclair, (1990), p. 218

${ }^{144}$ Olssen, Erik, (1984), p. 187 
the wealthy. The system had failed, they said, to promote a fair and equitable distribution of wealth, or even to ensure regular and constant employment for all those willing and anxious to work, ${ }^{145}$ while it had allowed wealth to flow into the hands of a minority. The root of the problem lay, according to the Bishops, in the neglect of the moral law, and they encouraged society to return to a Christian life and Christian institutions. Governments, they argued, should aim at bringing about a better distribution of wealth, and individuals should practice more thrift and economy, especially in regard to certain kinds of pleasure and amusements, which bring them neither health, happiness, nor prosperity. ${ }^{146}$ Catholics were encouraged to do what they could to help those who were needing relief, by supporting the Church's charitable societies or giving alms, and it was recommended that those parishes which were able, were to get building schemes organised as a useful contribution ....towards solving the problem of unemployment. ${ }^{147}$ Employers and workers did not escape the attention of the Bishops either.

Employers must endeavour to show every consideration to their employees at the present time. Let them remember that the men are not mere machines or commodities, but human beings like themselves, and deserve to be treated as such. Those higher up must share in the sacrifices that are necessary. At the same time employees are not to forget that they have duties and serious obligations to those who employ them. But if both sides are prepared to give and take, and strive to act towards each other with justice and charity, more

145 Pastoral Address of the Archbishop and Bishops of New Zealand on the Present Economic Crisis. (There are no page numbers on the copy I have been given by the Wellington Diocese.)

146 ibid

147 ibid. ( E. R. Simmons, in In Cruce Salus, a history of the Auckland Diocese, points out that Diocese gave work to hundreds of people during the depression with its building programme for schools, and churches in particular. (p. 244)) 
harmony and good fellowship will prevail...148

The Pastoral Address was an important and creditable comment from the Church, which made it clear to all where the sympathy of the church lay. In all parts of the country, even conservative Dunedin, Catholics accepted a commitment to social and economic justice, ${ }^{149}$ especially after the 1932 riots, and a considerable number of Catholic lay people became extremely influential in the Labour Party, joining those from other denominations who saw the party as a political symbol of practical Christianity. Among those who did not move into the political arena were many others who were active in helping the unemployed of all denominations, although there is little mention in Catholic diocese newspapers of the involvement of both religious and lay people with relief programmes. ${ }^{150}$ Despite the silence however, the instructions of the bishops were well heeded.

One denomination which was initially slow to respond vocally to the distress caused by the depression was the Baptist Union. Social services were active from the onset of the depression, ${ }^{151}$ but Assembly meetings did not appear to reflect the concern of the churches about the situation which had arisen throughout the community. Even in 1932 there seemed to be more interest in the financial state of the Union than in any social

148 ibid.

${ }^{149}$ Olssen, (1984), p. 187

${ }^{150}$ Simmons, p. 244

${ }^{151}$ Beilby, G. T., A Handful of Grain. The Centenary History of the Baptist Union of New Zealand. Vol.3: 1914-1945, p. 84 
predicament - As yet, Assembly did not see the economic state as a moral issue. ${ }^{152}$ In fact the Union was actually more concerned about the promotion of rail travel on Sundays than it was about any economic issues. ${ }^{153}$

Sluggish as it had been about recognising the problem of the depression, when the Baptist Assembly finally made a statement in 1933, it was a strong one. ${ }^{154}$ It deplored the inefficiency of the Government in providing productive work for relief workers given that there was a revenue of four million pounds from unemployment taxation, and demanded that the Government start providing relief funds especially for unemployed women and children. ${ }^{155}$ The economic system was indicted as hopeless by the Assembly, by reason of the millions of unemployed, underfed, and ill-clad people in the world, who had been failed by it. ${ }^{156}$ Two years later a further statement was made at the Annual General Meeting of the Central Auxiliary of the Baptist Union, criticising Government inertia, and urging it to do something about providing adequate provision for the needs of the unemployed and their families. ${ }^{157}$

152 ibid, p. 88

153 ibid

${ }^{154}$ It is possible that the initial slowness of the Baptist Union to respond was based on its puritan background, and its attachment to the work ethic, but there is no reason given by Beilby for the change in attitudes which occurred. Perhaps the effect of the depression on its members was the cause.

155 Beilby, p. 89

156 ibid

157 ibid, p. 90 
The Methodist Church, which like the Roman Catholic Church, attracted larger numbers of working class people than most other denominations, recognised the problems of unemployment from an early date. The Social Creed affirmed by the 1922 Methodist Annual Conference, stated that the Church stood: -

For the removal of the root causes of poverty and unemployment, including vice, waste and extravagance, as well as those causes relating to the purely economic aspects of trade and education. ${ }^{158}$

A fair wage, reasonable hours of work and adequate leisure time were advocated by the Conference, but most importantly individuals were reminded that industry was not merely competition for personal gain, but was intended to be used for the good of the community. ${ }^{159}$

Long involved in relief social services, the Methodist Church in 1933 began to issue statements about the wasteful and demoralising nature of much of the work at present provided, appealing to the Government to do something about extending the principle of productive employment..$^{160}$ Over the next two years the Church's Annual Conferences spent a significant amount of time examining the whole issue of unemployment, from both a spiritual and practical point of view, issuing statements to not only challenge the Government but their own members. Recognising that times had changed, the Methodist Church recommended that the Church needed to reconsider the value of human beings in light of modern industrial and commercial life, and pointed out that: -

${ }^{158}$ Cited in Davidson, Allan K. \& Lineham, Peter J., Transplanted Christianity, p. 280

159 ibid

160 ibid, p. 285 
The task of Christian men and women is not only the proclamation [of the Kingdom of God], but also the realisation of a social order built up on the principles of Christ which will include the God-given right of men to work, and from the fruits of labour to participate in a full and spacious life. ${ }^{161}$

Further to this the Church went on the next year to recommend that: -

Since Christ was so concerned for the full-orbed development of personality, we regard it as the duty of every Christian to seek to remove all hindrances to that development. Acute poverty, economic insecurity and fear are gravely prejudicial to human well-being and, therefore, their elimination is matter of urgency....

It is the duty of Christian men to plan and work for an economic system that genuinely express the ideals of Christianity. ${ }^{162}$

In a broader context the Church also urged the Government to review the economic system, and demanded that it looked at changing relief camp policies, the amount given in sustenance payments, taxation policies, and the lack of help given to women. ${ }^{163}$ It would appear however, from the minutes of the Annual Conferences 1935-36, that the Government took very little notice of the Church's exhortations.

Considering the comment made earlier regarding the "puritan and Presbyterian background" of New Zealand, it is not surprising that in the early days of the depression the Presbyterian church identified closely to the Government, and that it was slow to emerge with a critical response to the Government's handling of the situation. ${ }^{164}$ Like the Baptist Union, in 1930 it was more concerned with the running of excursion trains

161 Minutes of the New Zealand Methodist Conference, 1934, p. 69

162 Minutes of the New Zealand Methodist Conference, 1935, p. 72

163 Minutes, 1934 , p. 69-70. Similar demands were made the following year.

164 Davidson, in McEldowney, p. 103 
on the Sabbath than it was about the economic recession, ${ }^{165}$ and it was not until 1931 that any official recognition was given to the depression sweeping the country. ${ }^{166}$ For a period of some months however, articles had been appearing in The Outlook, the Presbyterian newspaper, discussing the unemployment problem. Initially, the major issue addressed was the difference between the man who was unemployed and the one who was unemployable. ${ }^{167}$ Despite the fact that a proportion of the population at that stage was still trapped by nineteenth century notions which labelled all unemployed as lazy, and able to get work if they really tried, the editor of The Outlook recognised that most unemployment was due to causes over which the worker has no control, ${ }^{168}$ and that most unemployed men were earnestly seeking a job. A response to the first editorial, from a Reverend E. J. Tipler, demonstrated that others in the Church were also increasingly aware of the crisis facing the country.

The unemployable and the parasite have always been with us, for the different orders and classes of society have their hangers-on. But this present state of affairs has eclipsed all others that ever afflicted us. Sober, steady workmen who took pride in their work and made it minister to their self-respect are now to be found by the hundreds in the sad processions of the unemployed. ${ }^{169}$

A later editorial in the same year was highly disparaging of much of the relief work

${ }^{165}$ ibid

${ }^{166}$ In the Committee Reports to the General Assembly of the Presbyterian Church of New Zealand, 1931, the report of Life and Work Committee minuted the appointment of a Special Assembly Committee to consider the whole question of the depression in relation to the Church. (I have no page number noted for this)

${ }^{167}$ Editorial, The Unemployment Problem, The Outlook, 2 March, 1931, p. 4

168 ibid

169 Tipler, E. J., Unemployment, The Outlook, 16 March, 1931, p. 4 
forced upon the unemployed, arguing that much of the work beget no pride in the worker, and in fact if anything, was likely to engender something akin to disgust. ${ }^{170}$ Critical comment was also made that no provision had ever been made by the Government for the eventuality of unemployment, and perhaps somewhat surprisingly, the editorial advocates a system of unemployment insurance.

Just as the 1932 riots were blossoming into reality, a significant article was published in The Outlook which examined the spirituality of unemployment. Firmly entrenched in the traditional values of the Victorian work ethic, it nevertheless illustrates that some Church members were reflecting seriously on the issues. The Reverend W. Maclean wrote: If civilisation begins with work, then work must be a divine ordinance; and every man who honestly desires work ought to be given the opportunity to work, as a right. That right, that opportunity, is denied to millions of men throughout the world today. It is a tragic spectacle, and I suggest that the tragedy is that they are workless, rather than they are in want and are hungry. The real tragedy is spiritual, the fact that they are caused to feel they are unwanted, useless members of society.....

That the spiritual is the real tragedy of unemployment is illustrated and confirmed in the cases of those who suffer no actual privation because they are out of work, yet feel ashamed by the thought that they have offered their services to society and been rejected. ${ }^{171}$

Regardless of these expressions of awareness in The Outlook, when Presbyterian Assembly Committees began to report on the depression in 1932 it is fascinating to find that whereas the especially appointed Sub-committee on Unemployment had begun to

${ }^{170}$ Editorial, The Problem of Unemployment, The Outlook, 17 August, 1931, p. 5

171 Maclean, W., The Spiritual Tragedy of Unemployment, The Outlook, 11 April, 1932, p. 8 
show real understanding of the issues, the Public Questions Committee was obviously still struggling to come to terms with the depression. The latter Committee warned that while economic values were important in their place, There is a danger, even in the Church, lest the depression should become an obsession. ${ }^{172}$ The blame for the international situation was put upon a travesty of the principles of Christ, ${ }^{173}$ and the Committee suggested that God's Rule or Kingdom was the true and ultimate solvent of the world's problems and difficulties. ${ }^{174}$ While recognising that many "worthy" office bearers in the Church were either unemployed or on relief work, the Committee seemed almost reluctant to acknowledge a need to study the facts and causes of the depression.

The Committee on Unemployment on the other hand was more realistic in its summary of the situation facing the country. Bluntly acknowledging the some 45,000 registered unemployed, the Committee recognised some of the causes of the depression, and discussed the importance of work for the individual, before concluding with a series of resolutions which were the first indication that at least part of the Presbyterian Church was finally questioning Government policies. The final resolution read: -

That the present methods of unemployment relief and charitable aid are quite inadequate to solve the main problem of unemployment, which is now assuming the proportions of a menace threatening the very foundations of our national life, and which calls for a constructive national policy rather than an increase in mere palliative measures. ${ }^{175}$

17 Committee Reports to the General Assembly of the Presbyterian Church, 1932, Public Questions Report, p. 98

173 ibid

174 ibid, p. 99

175 Cited in Davidson, in McEldowney, p. 103 
The hint of divergence detected in the 1932 Assembly reports continued in 1933, with one history of the Presbyterian Church recording that the division was largely between those who wanted the Church to take a more political stance and those who were believed such issues did not belong in the church. ${ }^{176}$ Once again the Public Questions Committee, although it recognised the worthiness of the work being done by Church members for those affected by the depression, encouraged the Church not to lose sight of the need for a national and personal return to God. ${ }^{177}$ There was a necessity, the Committee declared for emotional penitence and a deep longing to know His will for the social order. ${ }^{178}$

This is not to say that the Economic Sub-Committee ignored the need for the establishment of a social order that would permit people to hear the voice of God, ${ }^{179}$ but it did criticise those people who were seeking to blame individuals or groups for the economic troubles, and who were trying to use short-cut policies to rectify matters.

For example, condemnation of the unemployed as being ungrateful, indolent, dissatisfied, blaming the Jews for the depression, ranting about capitalism, and uncritical enthusiasm over new credit schemes or Communism, are positively dangerous. ${ }^{180}$

176 ibid, p. 104

177 Committee Reports to the General Assembly of the Presbyterian Church, 1933, Public Questions Report, p. 82

178 ibid

179 ibid, Report of Economic Sub-Committee, p. 82

180 ibid, p. 83 
Unemployment, the Committee, observed, is a disease of the body corporate, ${ }^{181}$ and it considered that it is both false and cruel to consider the unemployed as an isolated section of the community. ${ }^{182}$ The Report went on to raise the question about the meaning of industry, pointing out that it should exist for the benefit of the community not for the accumulation of personal wealth. The root causes of the depression, it suggested, were not overproduction, or mechanisation, or the hoarding of assets, but the bankruptcy of our spiritual resources. ${ }^{183}$

Although the Presbyterian Church appears to have been relatively quiet about the issues of unemployment and the depression from this point, ${ }^{184}$ nevertheless it did join with the other major denominations in advocating radical social and political change, and as support for the Coalition Government was withdrawn, Church leaders gave tacit approval to the welfare policies of the Labour Party. ${ }^{185}$ It has to be noted however, that some concern was expressed by the Presbyterian Church following the actual election of the Labour Government, regarding the issue of idleness resulting from sustenance payments. The Assembly Committee on Social Relationships cautioned the Church about the advent of too much leisure, anxious that beyond the amount needed for rest,
181 ibid
182 ibid, p. 84
183 ibid

184 The Outlook from April to September, 1935, published a series of articles and correspondence about the chaos of the social order, which among other issues, examined the economy and its failings.

${ }^{185}$ Davidson, in McEldowney, p. 105 
Satan will still find mischief for idle hands. ${ }^{186}$ The following year's report from the same Committee, frets about the number of young men said to be quite content to live on sustenance payments and is disturbed about the obvious tendency towards creating a body of loafers. ${ }^{187}$ As the depression began to wane, the earmarks of the work ethic were being put firmly back into place, by the Presbyterian Church at least.

The Presbyterian Church was not alone in this among the denominations. For example, an important question was raised by the Baptist Assembly in 1936 as the depression was easing, that seems like a direct appeal to the puritan theology of former days. It asked its member churches to consider: -

How industry, which once rested on a religious base but has become secularised and materialistic, be restored to sanctity and become a temple of human brotherhood? ${ }^{188}$

Possibly only the Methodist Church had begun to move from the rigidity of work ethic values as a result of the depression, when it stated strongly in the midst of its 1936 social and political agenda, that as a Church it believed that Man has been placed in this world to live and that work is secondary to living. ${ }^{189}$

${ }^{186}$ Committee Reports to the General Assembly of the Presbyterian Church, 1936, Report of Committee on Social Relationships, p. 180

187 ibid, 1937, p. 243

188 Beilby, p. 91

189 Minutes of the New Zealand Methodist Conference, 1936, p. 69. The emphasis belongs to the Methodist Church minutes. I think I would want to add emphasis to the word "secondary." 
Tony Simpson claimed in The Sugar Bag Years that the depression swept away what he called the pettifogging and humbug, and the pretence of social distinctions. Old shibboleths failed, he wrote; the slate was wiped clean. ${ }^{190}$ The primary fundamentals of the work ethic might have been questioned by those who found themselves forced into ineffectual work simply to be able to survive, and those in social services who worked to assist them, but essentially it was still alive and thriving at the end of the depression. The work ethic was one shibboleth which did not fail; it may have faltered over the next few decades but the next economic depression brought it back into play for another generation of politicians to wield as an official weapon against the unemployed.

${ }^{190}$ Simpson, (1984), p. 16 


\section{A glimpse of Utopia -}

\section{a brief interlude}

To understand the apparent persistence of the concept of the work ethic it is necessary to reflect on the social and economic experiences of the years 1938-60, before moving to examine the economic and political transformation which occurred in New Zealand 1984-92.

The vivid memory of the mass unemployment and profound insecurity of the Great Depression ensured that postwar governments devised monetary and public expenditure policies - based on the economic theories of John Maynard Keynes - which were designed to sustain the so-called miracle $e^{1}$ of full employment. Backed by the welfare state introduced in the late thirties by the Labour Government, and the subsidies and licences which supported many new industries, full employment undergirded the most sustained period of affluence New Zealand had ever known. ${ }^{2}$

For those who found themselves in need through ill health, old age, or unemployment, there was a social security system initially second to none in the western world, based on the universal principle that regardless of wealth or the ability to work, there were

1 Rosenberg, W., (1960), Full Employment. Can the New Zealand Economic Miracle Last? The very title of his book points to Rosenberg's belief in the miracle of full employment; early in the book he refers to his belief that New Zealand's economic experience can well be called miraculous. (p. 12)

${ }^{2}$ Dunstall, Graeme, The Social Pattern, in Oliver, \& Williams, (eds), p. 398; EldredGrigg, Stevan, (1990), p. 173 
cash benefits available for all. $^{3}$ Compared to the previous arbitrary support from charitable aid and other agencies, the new benefit system had a sense of entitlement and lack of shame $e^{4}$ that afforded individuals a sense of dignity and respectability hitherto not experienced by those collecting welfare sustenance.

The solid Christian base of the first Labour Government ${ }^{5}$ and its reasoning for the introduction of the welfare state, is reflected in statements made by its leaders as early as 1938. The Select Committee on National Health and Superannuation declared in its 1938 Report: -

that public opinion in the Dominion requires that the normal Christian attitude of helping those in need, whatever the cause of their need, should be carried on into the community life, enabling the joint resources of the people to be applied for assisting in banishing distress and want. ${ }^{6}$

As one scholar has noted, the welfare system was not the creature of a poor country. It was the humanitarian creation of a country that had reason to believe that the problem of economic security had been solved. ${ }^{7}$ Regardless of the economic soundness of this social gospel, ${ }^{8}$ the Social Security Act of 1939 became the basis of a welfare

${ }^{3}$ McClure, Margaret, $A$ Civilised Community, p. 83.

${ }^{4}$ ibid

${ }^{5}$ Hobbs, Leslie, The Thirty-Year Wonders. There were at least four Cabinet members with a Roman Catholic upbringing, including Joseph Savage the Prime Minister, (p.156), a Presbyterian minister, Arnold Nordmeyer, (p.101), and a Church of England lay reader, Walter Nash (p. 67)

${ }^{6}$ Cited in McClure, p. 75

7 Jones, Michael, Reforming New Zealand Welfare. International Perspectives, p. 40

8 Savage claimed it was part of New Zealand's Christian heritage to provide social security for all citizens whether this was sound economics or not. (Cited in McClure, p. 
system that was supported over the next three decades by full employment.

Although the new welfare state allowed for New Zealander's with poor work histories to be eligible for the same benefits as those who had worked hard and contributed significant amounts to the taxes of the welfare state, there was, nonetheless, an emphasis on work by the Labour Government of the postwar years. Labour leaders made it clear there was a concomitant obligation to work for the common good ${ }^{9}$ in return for the sheltering umbrella of the social security system. The Minister of Works, Bob Semple, in a speech concerning an increase in benefit rates in 1945, made the following statement: -

There is a duty, too, on individuals to respond to a benevolent Government that does that, and to pull their weight...malingering on the job, stupid stop-work meetings, and all kinds of " monkey tricks" played on industry will not help to make this measure a success...They must put their shoulders to the task allotted to them and pull their weight...If they regard this as something sacred which will give the rest of the world a lead, they will work as they have never worked before. $^{10}$

For the decade of the 1950s New Zealanders really believed they had cracked the secret of affluence with security, ${ }^{11}$ with only a tiny $0.07 \%$ rate of unemployment, ${ }^{12}$ and workers happily aware that they could pick and choose where they worked, and secure

80)

${ }^{9}$ McClure, p. 104

${ }^{10}$ ibid

11 James, (1992), p. 9

12 James, Colin, (1986), The Quiet Revolution, p. 55 
in the knowledge that if they were dismissed, there would always be another job to go to. ${ }^{13}$ There was an assumption that due to New Zealand's natural endowments it would always remain a wealthy society, and the maintenance of a high standard of living underpinned much of the government policy of the era. Rather than focusing on the further development of wealth, the economic policy concentrated on the distribution of wealth and preserving the social objectives of the welfare state. ${ }^{14}$

Utopia however, was once again to escape from the grasp of New Zealanders, just as it had in the nineteenth century. Fluctuations in the economy during the fifties, and a dependency on open access to markets in Britain, were inevitably going to lead to cracks in the economic complacency of the population. In 1958 the first real signal came with the black budget ${ }^{15}$ of Labour's Finance Minister, Arnold Nordmeyer, which despite its unpopularity, successfully stemmed the flood of imports into the country and turned the terms of trade around. ${ }^{16}$

The country however, had no desire to return to planned austerity. ${ }^{17}$ Nordmeyer's budget struck at New Zealanders' pleasures. In a society where life had become complaisant, the puritan ethic of hard work and abstinence exhibited by politicians such

13 Eldred-Grigg, (1990), p. 173

${ }^{14}$ Crocombe, Graham T., Enright, Michael, J., \& Porter, Michael, E., Upgrading New Zealand's Competitive Advantage, pp 150, 153.

15 Chapman, Robert, From Labour to National, in Oliver \& Williams, (eds), p. 364

${ }^{16}$ Eagles, Jim, \& James, Colin, The Making of a New Zealand Prime Minister, p. 28

17 Chapman, in Oliver \& Williams, (eds), p. 364 
as Nordmeyer ${ }^{18}$ and Walter Nash ${ }^{19}$, was increasingly unfamiliar. For the first time in New Zealand's history, the work ethic faltered for there had been no conception when the welfare state had been established that it was an independent force that could change behaviour, create new needs, and could change incentives. ${ }^{20}$

${ }^{18}$ Eagles \& James, p. 28

19 Sinclair, Keith, (1976), Walter Nash, p. 339, states Hard, long hours of work were central to his self-regard.

${ }^{20}$ Jones, p. 52 


\section{CHAPTER 5}

\section{"To move attitudes, to change behaviour and foster a better work ethic" $^{\text {"1 }}$ - the transforming of New Zealand}

When Alvin Toffler published his book, Future Shock, in 1970, New Zealanders were to all intents and purposes still clinging to a nineteenth century world view. While the rest of the world was beginning to come to terms with changing values and ideas, New Zealand was faithfully nurturing what has been described as a Victorian, lower middle class, Calvinist, village mentality. ${ }^{2}$ As Toffler wrote of an avalanche of change ${ }^{3}$ confronting the world, New Zealanders were blithely patting themselves on the back and believing that they lived in God's own country, the richest nation in the world. ${ }^{4}$ Complacency was rife.

But the next two decades were to see a convulsion of change. By 1992 one commentator was able to observe, New Zealanders have come into the 1990s shellshocked from change. ${ }^{5}$ The phenomenon described by Toffler as future shock ${ }^{6}$

1 Richardson, Ruth, Address..., 27 March, 1991, p. 6

${ }^{2}$ McLauchlan, Gordon, (1976), The Passionless People, p. 1

${ }^{3}$ Toffler, Alvin, Future Shock, p. 20

${ }^{4}$ Douglas, Roger, Toward Prosperity, p. 13

5 James, Colin, (1992), New Territory. The Transformation of New Zealand 1984-92, p. 5

${ }^{6}$ Toffler describes future shock as a product of the greatly accelerated rate of change in society. Individuals suffer dislocation when moved into a culture different from their 
rippled through society, causing a dislocation in the traditional economic, political and moral values within the community. The complacency of the postwar decades was demolished, and the colonial era of New Zealand finally came to an end. In short, wrote Colin James, New Zealanders were struck by a tidal wave that burst through the colonial, economic and intellectual defences they had erected around themselves. ${ }^{7}$

Central to many of the changes which manifested themselves between 1960-1992 was the issue of work. From the phenomenon of full employment in the decades following the Thirties Depression and the Second World War, to the experience of 216,000 unemployed in $1992,{ }^{8}$ the question of the work ethic was still fundamental to many economic and political concerns. In 1984, despite the growing numbers of unemployed and the economic crisis facing the country, one economist at least, argued that New Zealand remains a country where hard manual work can be the basis of social standing and success, ${ }^{9}$ and many economic policies demonstrated the ongoing belief that a right attitude by working people would solve the nation's fiscal difficulties. By 1992 it would be reasonable to argue that while the churches had stopped preaching the traditional work ethic, and were in fact questioning its validity, ${ }^{10}$ the politicians had taken it upon

own but when they are unable to return to their own environment, and the new culture is constantly changing, the disorientation is doubly severe. When a whole society is suddenly confronted with a new culture imposed on their familiar "old" culture, the result is mass disorientation, future shock on a grand scale. (p. 20)

${ }^{7}$ James, (1992), p. 277

8 ibid, p. 180

9 Harvey Franklin, cited in James, (1992), p. 19

10 Chapter 8 will examine the response of the churches to the changing patterns in the ideology of work, and also discuss the response of the churches to the economic 
themselves to proclaim the virtues and necessity of a good work ethic. ${ }^{11}$

Nineteen-sixty has often been described as a watershed between the Reformation and a completely new era in history. ${ }^{12}$ Certainly the questioning of long held values and beliefs initiated during the sixties began to challenge the complacency and comfort of a whole generation of New Zealanders who had an urgent desire to avoid any repeat of the depression years. New Zealand was one of few nations still following Keynesian principles ${ }^{13}$ and pressure was beginning to mount from outside the country as foreign investors looked with interest at New Zealand, ${ }^{14}$ and from within as employers and private enterprise began to balk at full emplovment ${ }^{15}$ and insreased taxation ${ }^{16}$

The complacency of New Zealanders' with the exceptional state of their economy, their lack of recognition that New Zealand has achieved something no other capitalist country in the world has achieved equally well, is one of the

restructuring 1984-92

11 Ruth Richardson in particular used the term "work ethic" when announcing policies regarding employment and welfare. Her speeches in March and April 1991 which I have already quoted from are examples. (See Chapter 1 , note 3 , and the title of this chapter). Other politicians may have not been so specific but nevertheless it is clear that their understanding of work is frequently based on the traditional notion of the work ethic, as will be shown later in this chapter.

12 Veitch, James, 1961-1990 Towards the Church for a New Era, in McEldowney, Dennis (ed), p. 150. Veitch is referring to the ideas of Sydney Ahlstrom.

${ }^{13}$ Rosenberg, (1960), p. 64

${ }^{14}$ ibid, p. 109

${ }^{15}$ Eldred-Grigg, (1990), p. 173. "Full employment" was becoming criticised as being "over employment" by many in the business sector, who complained that there were more jobs than workers.

${ }^{16}$ Rosenberg, (1960), p. 64 
greatest threats to full employment in New Zealand, ${ }^{17}$

wrote Rosenberg in warning. New Zealanders, he went on to say, did not realise in what precarious balance a private enterprise economy must find itself to maintain full employment, stable prices and absence of exchange crises. ${ }^{18}$

The acquisitive materialism which accompanied the prosperity of the country, however, proved to be insatiable. ${ }^{19}$ Incomes rose steadily, with compulsory unionism guaranteeing not only jobs, but also ever increasing wages. ${ }^{20}$ Workers began to complain about indirect taxation apparently not understanding that the welfare benefits they took for granted, for example in health and education, were dependent on full employment and their financial contribution through the taxation system. ${ }^{21}$ Largely ignored by the average New Zealander, the economic strain which was to beset the welfare state began to show itself in the mid-sixties. Disturbing fissures were also beginning to show in the infrastructure of full employment and Rosenberg's fears were to be justified as the economy began to decline, and welfare generated promises of affluence became increasingly unpredictable.

17 ibid

18 ibid

${ }^{19}$ Dunstall, p. 398

20 James, (1992), p. 27

${ }^{21}$ Rosenberg, W., (1977), Full employment: the Fulcrum of Social Welfare, in Trlin, A. D., (ed), Social Welfare and New Zealand Society, p. 46. Rosenberg makes it clear that without full employment many of the government's policies would be unattainable. 
Suggestions have been made that the National Government of the 1960s should have done more to diversify the economy when times were relatively prosperous. ${ }^{22}$ Keith Holyoake, the Prime Minister, however, consistently sought stability. His greatest feat it is said, was the slowing down of every process which if speedily dealt with, might have represented change and political harm. ${ }^{23}$ There was an implicit assumption by Holyoake and the National Governments of the 60 s that New Zealanders wanted security and continuity, completely ignoring that the upcoming generation, who had known nothing but security, was now looking for other things. ${ }^{24}$

It was the seventies that saw the real turning point for New Zealand. Wedded to the idea of the welfare state and full employment, many found their foundations beginning to tremble as the accepted economic and social pattern began to change. As recession set in with inflation rates soaring to $15-17 \%$ in $1975,{ }^{25}$ and with unemployment climbing to levels not seen since the Great Depression, it began to emerge that many New Zealanders had no moral or social philosophy, no dream of the future, beyond the orthodox good health of that pagan god, The Economy. ${ }^{26}$ With the evaporation of that sense of financial well-being that had accompanied the years of full employment, New Zealanders turned, as they had done in the past, to the state for solutions. Both the

22 Brooking, Tim, 'Tobacco Road to Pipitea Street': Holyoake and the FarmerPolitician Tradition, in Clark, Margaret, (ed), Sir Keith Holyoake. Towards a Political Biography, p. 123

${ }^{23}$ Chapman, in Oliver \& Williams, (eds), p. 365

${ }^{24}$ Eagle \& James, p. 218

${ }^{25}$ Templeton, Hugh, All Honourable Men, p. 48

${ }^{26}$ McLauchlan, (1976), p. 2 
Labour and National Governments of the 70 s responded by borrowing to numb the pain. They regulated, controlled, subsidised and doled out borrowed money. ${ }^{27}$

The Labour Government found itself defeated in 1975, for despite its efforts the economy was deteriorating rapidly. The incoming National Government was led by Robert Muldoon, who as a citizen of the Depression, ${ }^{28}$ was not prepared to watch his country go down that same path again. There is little doubt that Muldoon's personal background influenced his economic and political decisions. ${ }^{29}$ In his autobiography, Muldoon, he describes his teenage years during the Depression as not being easy. His mother, by dint of hard work, provided adequately - if frugally..., ${ }^{30}$ but Muldoon said that nevertheless he had seen much real poverty and degradation during the Depression. ${ }^{31}$ As a result he stated strongly that he would not ever wish to see the 1930 s repeated in this country, ${ }^{32}$ and Hugh Templeton, one of Muldoon's Cabinet members, confirms that between 1975-78, Muldoon had driven himself and his ministers hard with a clear recollection of the Great Depression in mind. He did not want to see his

27 James, (1986), p. 73

28 Templeton, p. 92

${ }^{29}$ Like George Forbes in the 1930s, Muldoon was a product of his times. As Forbes had been a child of the nineteenth century and Victorian values, Muldoon was a child of the thirties depression. It was inevitable they would, each in his turn, govern from the perspective of their early experiences.

${ }^{30}$ Muldoon, Robert, Muldoon, p. 3

31 ibid, p. 5

32 ibid, p. 6 
New Zealand suffer like that again..$^{33}$

Unfortunately Muldoon's convictions, built on his past experiences and several generations of the welfare state, made it difficult for him to recognise the change in New Zealand's fortunes. Templeton writes : -

The New Zealand ship of state, its economy and its people were being borne on oceanic currents that took us from safe haven and sure landfall. The Captain was too concentrated on safe-guarding the New Zealand he had known, and felt sure the people wanted, to look for new directions. ${ }^{34}$

Muldoon was probably correct to a large degree in his assumptions that New Zealanders agreed with him, at least during his first term as Prime Minister. The concept of security from the cradle to the grave was firmly embedded not only in his mind, but in the understanding of many New Zealanders who had grown up with the notion that the country could be protected from international fluctuations, and that internal living standards were guaranteed regardless of overseas influences.

The philosophy of full employment with its tight government control was still fresh in Muldoon's thinking, and it never occurred to him to consider deregulation and a more market-driven economy according to Templeton. ${ }^{35}$ Instead he yearned for a continuation of the days when every New Zealander wanting to work could have a job with decent wages, and a perpetuation of the burning urge to work and achieve that had

33 Templeton, p. 113

34 ibid, p. 4

35 ibid, p. 65 
manifested itself in the survivors of the depression. ${ }^{36}$ As a consequence he refused to consider the tougher economic measures which in other nations had led to severe unemployment. Muldoon believed: -

people are the essence of economics. Unless you understand the people of the country, their hopes, their fears, and their responses to stimuli and adversity, you will never be able to understand the economy of that country or indeed have any flair for economic management.

Wealth is for people, and the ultimate satisfaction in the broadest sense of the great mass of the people must be the true aim of all sound economic policy. ${ }^{37}$

In his attempts to satisfy the people and maintain the prosperity of the previous decades however, Muldoon became increasingly conservative during his second term in office, and hunkered down rather than risk shifts of course that were essential to the economy and New Zealanders. ${ }^{38}$ In doing so he ignored not only the rising unemployment figures, but also the rising generation of intellectual and economic elite who were proclaiming individualism and independence. ${ }^{39}$ Believing that he could resist the winds of change that had been sweeping the rest of the globe, and that were shaking the establishment in New Zealand, Muldoon unwittingly prepared the way for his radical opponents who were to drag New Zealand unaware into a painful and socially divisive decade of

36 Muldoon, p. 6. Muldoon questioned in his autobiography if the new generation was being instilled with work habits and the understanding that reward would not occur without work. He seemed doubtful that this was so. (p. 5)

37 ibid, p. 40

38 Templeton, p. 4. The argument is given by Templeton that Muldoon reacted this way in an effort to hold power. Colin James (1986) comments that Muldoon was not prepared to risk signing his own political death warrant with austerity measures. (p. 74)

39 James, (1986), pp. 74-5 
reform..$^{40}$

By early 1984 Muldoon was in deep trouble with both the internal and external economy, ${ }^{41}$ and his call mid-year for a snap election was an obvious misjudgment on his behalf. Totally out of step with the mood for change, Muldoon did not recognise the disillusionment with his policies, or the antagonism which had built against him personally as a leader. As Colin James observes: -

pressure for big change was banked up. Big change was seeping through the cracks in the conservative Muldoonist dam. All that was needed for that seepage to turn into a flood was catalyst. The election of a Labour Government..... was that catalyst. ${ }^{42}$

Many of the members of the Fourth Labour Government which swept to power in 1984 were from that new generation of intellectuals and elite which had begun to challenge not only Muldoon's fundamental beliefs, but also those of the general population. ${ }^{43}$ Born into an environment of affluence and security, and an age of questioning and rejection of traditional ideas, these individuals had begun to materialise in positions of power throughout society, and surprisingly given its socialist beginnings, ${ }^{44}$ were the

${ }^{40}$ Templeton, p. 233

${ }^{41}$ James, (1986), p. 169

${ }^{42}$ ibid, pp. 65-6

${ }^{43}$ Jesson, Bruce, Fragments of Labour. The Story behind the Labour Government, p. 24

${ }^{44}$ Vowles, Jack, The Fourth Labour Government. Ends, Means, and for Whom? in Boston, Jonathan \& Holland, Martin, (eds), The Fourth Labour Government. Radical Politics in New Zealand, pp 16-20 
prime movers and shakers of the Labour party. ${ }^{45}$ Despite their divergence from the established strategies familiar to conservative New Zealanders, they were given carte blanche to govern the country, and to drive the changes the country was calling for.

They acted as if they had to look everything over and change it wherever there were imperfections, imagined or real, or a hint of old-fashionedness. And when they came to make changes, they seldom tinkered. They went deep. ${ }^{46}$

The symbolic embodiment of this reforming generation can be found in Roger Douglas, the Minister of Finance. His policy of "Rogernomics" became almost a dirty word in New Zealand before he was dismissed from Cabinet in 1988, but he was convinced that the pathways mapped out in the $1930 \mathrm{~s}$, and those of the recent National Governments, would lead to a social and economic wasteland if continued, ${ }^{47}$ and that there had to be a fundamental change in the economic policies of the government. One writer comments:-

Labour's central economic direction was the mirror image of National's. While National attempted to promote economic growth, Labour actively induced a recession. Both Governments... abandoned the goal of full employment. ${ }^{48}$

Douglas was heavily influenced by a worldwide trend towards a market-oriented

45 James, (1986), p. 166. Vowles, p. 24, also observes that $75 \%$ of the 1984 Labour Government caucus came from professional occupations, compared to $66 \%$ in 1935 . From being a working class party at the time of its origins, the social composition Labour party was gradually changed to that of middle class. During the 1970 s middle class liberals previously aligned to the National party began to gravitate to Labour.

${ }^{46}$ James, (1992), p. 99

${ }^{47}$ Douglas, p. 9

${ }^{48}$ Leitch, Shirley, News Talk. Media Stories on Unemployment, p. 10 
approach, and monetarism. ${ }^{49}$ Rejecting previous attempts to insulate New Zealand from the international economy, and backed by the Treasury ${ }^{50}$ and the Reserve Bank, he introduced a whole range of policy changes designed to integrate New Zealand into the world economy, and limit government intervention in the economy. ${ }^{51}$ Export and investment incentives, and job subsidies were dismantled. ${ }^{52}$ Protectionism was reduced, and restrictions on foreign investment relaxed. The financial sector was deregulated, the dollar was floated and the Reserve Bank was given more autonomy. State assets were privatised, ${ }^{53}$ and the public sector was reformed..$^{54}$

During all this modification of economic policies, the issue of full employment was

${ }^{49}$ Collins, Simon, Rogernomics. Is there a better way? pp. 30-3; Whitwell, Jan L., The Rogernomics Monetarist Experiment, in Holland, Martin \& Boston, Jonathan, The Fourth Labour Government. Politics and Policy in New Zealand, pp 101-122. Whitwell points out the just as New Zealand embarked on a monetarist experiment, the rest of the world was scaling down such experiments. (pp. 118-19)

${ }^{50}$ It was a popular belief at the time that the Labour Government was heavily influenced by Treasury, and that many of the policies were dictated by Treasury officials who had moved outside of their official capacity in doing so. References can be found in Endres, A. M., Perceptions of "Full Employment" in Relation to Other Major Policy Goals, 1984-88, in Easton, Brian, (ed), The Making of Rogernomics, p. 138; Shirley, Ian; Easton, Brian; Blair, Celia \& Chatterjee, Srikanta, Unemployment in new Zealand, p. 33; Shirley, Ian, The New Zealand Experiment, Accent, Vol. 3, No. 1, February, 1988, pp $1-13$, and several other sources. Douglas on the other hand cites the Secretary to the Treasury, Graham Scott, as saying, The public perception that somehow the Treasury has done this to them is bizarre. These are decisions taken by their elected representatives. (Douglas, p. 127)

51 Crocombe et al, p. 137

52 Collins, Simon, p. 21

${ }^{53}$ Crocombe et al, p. 137

54 The next chapter will examine the public sector reform in some detail and will analyse the effect of the reform on the work ethic of its employees. 
carefully sidestepped. Douglas, in 1982, had argued, The traditional Labour goal of greater social equality based on full employment and generous welfare services cannot be paid for without economic growth, ${ }^{55}$ and consequently the Labour Party manifesto for the 1983 election had nominated full employment as its top economic objective. ${ }^{56}$ As the country and foreign investors responded to Douglas's policies however, it became obvious that full employment in an export-led, freemarket economy, was impossible. ${ }^{57}$ Despite promises that it would only take five years to turn the economy around, by 1989 it was clear that instead of strong growth, the country was heading into deep recession. ${ }^{58}$ During the first four years of the Labour regime, inflation and interest rates had soared, and consumer spending had boomed along with sharemarket and property investment. What growth there was, was built on debt. ${ }^{59}$ The sharemarket crash in October 1987 rocketed the country into recession as borrowers found they could no longer service their debts, and thousands of companies collapsed. ${ }^{60}$ Unemployment spiralled out of control as jobs were lost with the disappearance of companies. ${ }^{61}$

Public criticism began to grow. An editorial in a Christian magazine in August 1988,

${ }^{55}$ Collins, Simon, p. 34. The emphasis belongs to Collins.

${ }^{56}$ Shirley et al, p. 33

${ }^{57}$ Rosenberg, W., (1986), The Magic Square, p. 106

58 James, (1992), p. 171

${ }^{59}$ ibid, p. 176

${ }^{60}$ ibid, pp. 177-9

${ }^{61}$ Shirley et al, p. 33, states that between 1984 and 1989 the numbers of registered unemployed rose just under 100,000. 
commented: -

As unemployment figures grow, the Minister of Labour blandly asserts that numbers will increase even further to 150,000 by the end of the year, but instead of putting their energies into job creation the government continues to wait for some mystical market to right itself without any government intervention. $^{62}$

Concerns were raised about the effects of Rogernomics on employment figures by intellectuals as well as Christians, as it became increasingly evident to the public that Douglas's policies were diametrically opposed to full employment, ${ }^{63}$ and that unemployment was simply regarded as an adjustment problem en route to' a more efficient economy'.64 The Reserve Bank acknowledgment that the rise in unemployment was related to policies aimed at creating a fall in output that was in turn expected to lead to the lowering of wages and a lowering of cost production and a disinflationary process ${ }^{65}$ resulted in one academic commenting: -

This postulated feedback from wage and price inflation via real wages to higher output and employment levels has great political appeal, for it neatly absolves a government from any responsibility for unemployment. Unemployment can be attributed to nominal wage rigidities over which a government has little control. ${ }^{66}$

The failure of employment levels to rise again in the manner predicted simply resulted in the economists attempting to explain unemployment away through market

\footnotetext{
62 Alison and Ron O'Grady, Editorial, Accent, Vol. 3, No. 6, August, 1988, p. 3

63 Shirley et al, p. 33

${ }^{64}$ ibid, p. 44

${ }^{65}$ Whitwell, in Holland \& Boston, (eds), p. 109

66 ibid
} 
imperfections, ${ }^{67}$ while supporters of Rogernomics refused to concede that it might be the tight monetarist policies of the government which were causing the problem, claiming instead that in reality the fiscal policies were too $\operatorname{lax}^{68}$

Condemnation, however, of the attitudes of the administration, Treasury and the Reserve Bank towards unemployment issues became increasingly common. Ian Shirley and his colleagues commented in their book on unemployment: -

The deterioration in New Zealand's employment record in the latter half of the $1980 \mathrm{~s}$ can be attributed to a series of policy decisions which were based on economic theories imported from abroad and promoted in this country by policy advisors (Treasury, Reserve Bank) who did not believe in the "miracle of full employment". These advisors, along with the changing guard in the finance sector, did not understand the social and economic benefits of full employment. ${ }^{69}$

Implied criticism is also noted in Endres' essay. Comments are made about the Treasury's unashamed recognition that high unemployment was a consequence of disinflation. Endres points out that by 1987:-

A sharp reduction in the demand for labour had by then been engineered in order to throttle inflation, although when the inflation rate declined to single figures the bogey of inflation expectations was used to rationalise continuing rising rates of unemployment..$^{70}$

One supporter of the Treasury policy Endres observes, considered the employment losses due to liberalisation as essentially 'political', indicating just how far it is possible

67 ibid

68 ibid, p. 113

69 Shirley et al, p. 44

70 Endres, in Easton, (ed), p. 139 
to jettison full employment from the economic policy agenda. ${ }^{71}$

Within the Government itself questions were also being asked about the social consequences of Rogernomics. While the Prime Minister, David Lange, had been prepared initially to support Douglas's policies on the basis of short-term pain leading to long term gain, he was never fully convinced about free-market methods. ${ }^{72}$ As Lange watched thousands of individuals being put out of work because of government policies, strains began to develop within the Party as it became increasingly obvious that the economic reforms which were supposed to fulfill the Party's social goals, were based on a philosophy fundamentally opposed to traditional Labour beliefs. ${ }^{73}$ Having quoted from the Gospel of Mark 1:16, (What does it profit a man to gain the world and lose his soul?), in his maiden speech as Prime Minister, it seems likely that Lange's Methodist upbringing, and social conscience started to cause him trouble as he observed the consequences of Rogernomics on New Zealand society. ${ }^{74}$ Surprisingly when Lange talked of the need to extend the government reforms into the area of social policy during the 1987 election campaign, he was supported by Douglas. The divergence of their intent, however, was to help break the Labour Party apart. Lange appeared to be advocating a social policy evocative of traditional Labour intentions, whereas Douglas was determined on a course of action involving the further slashing of government

71 ibid, p. 140

72 James, (1986), p. 161

${ }^{73}$ Jesson, p. 77

74 ibid, p. 102 
spending. ${ }^{75}$

In 1988, after months of wrangling over social policy, the differences of opinion between Lange, Douglas and their supporters, finally proved to be irreconcilable, and Lange sacked Douglas from his position as Finance Minister. According to one commentator, the ensuing bickering within the government brought the economic reforms to a halt. ${ }^{76}$ Lange's replacement by Geoffrey Palmer the following year further demonstrated the disintegration the Labour Party was experiencing. ${ }^{77}$ Too late the government under Palmer recognised that unemployment had lost them a lot of popularity, and that the 1990 election would be lost unless they were seen to be attacking the problem. Hastily, targets were set for cutting unemployment figures, and an assurance was given that the goal of the government's policies would be to return New Zealand to full employment. ${ }^{78}$

The opposition however, gave similar assurances, and it was no surprise when Jim Bolger's National party won the election with a campaign based on Creating a Decent Society. ${ }^{79}$ If the people of New Zealand expected a return to the old ways however, they were to be disappointed. Believing that Rogernomics had not gone far enough, Ruth

75 ibid, p. 109

${ }^{76}$ Return to Rogernomics, The Economist, 23 March, 1991, p. 81

77 Only six weeks before the 1990 election Mike Moore replaced Palmer as Prime Minister, as a further indication that the Labour Party was crumbling before the country's eyes. (Bolger, Jim, Bolger - A view from the top, p. 27)

${ }^{78}$ Goulter, John, Full employment by 1995 promised, Evening Post, 23 May, 1990

${ }^{79}$ Boston, Jonathan \& Dalzeil, Paul (eds), The Decent Society?, p. viii 
Richardson, the new Minister of Finance, and her supporters, ${ }^{80}$ had announced within seven weeks of taking office, a radical package of public spending cuts, labour -market reforms, and cuts in welfare benefits, ${ }^{81}$ as components of an assault on government spending. The welfare system became the target for both short and long-term savings, with Richardson and Jenny Shipley, the Minister of Social Welfare, in agreement over a philosophy regarding the need to make inroads into state dependency. ${ }^{82}$ Richardson claimed in her autobiography: -

Neither of us saw the exercise simply as one of budget-cutting. We saw it as restoring integrity to our social welfare system. We believed independence and self-reliance needed to be encouraged; that low-income workers should not be penalised compared with those on benefits; and that state assistance should be directed to people with genuine need. ${ }^{83}$

Earlier, in a 1992 article in a popular magazine, Richardson had said of the benefit cuts:-

It's about saving a culture. It's about self-reliance, it's about the sort of country we will become and are condemned to if we remain plugged into an allpervasive state which has corroded initiative, self-help and a sense of family values. $^{84}$

Such attitudes clearly indicated that politicians and their advisers no longer believed in traditional welfare system values. Jenny Shipley, the Minister of Social Welfare, for example in a press statement in 1991, said: -

${ }^{80}$ Bolger, pp 114-20, has a chapter entitled " The Gospel according to Ruth." I cannot decide whether this is tongue in cheek or not.

${ }^{81}$ Return to Rogernomics, ibid, p. 82

${ }^{82}$ Richardson, Ruth, Making a Difference, p. 84

${ }^{83}$ ibid

${ }^{84}$ Cited by St John, Susan, The State and Welfare, in Sharp, Andrew, (ed), Leap Into the Dark. The Changing Role of the State in New Zealand Since 1984, p. 94 
We are challenging most new Zealanders' beliefs and attitudes to the welfare state. If we misguidedly entertain instinctive, but woolly and anachronistic feelings of fair play, justice, co-operation, community and equality, then we must be re-educated so that we too become true believers in the values of competition, self-reliance, freedom, individualism, choice, and market signals.

Having dismissed the beliefs of several generations of New Zealanders, Shipley unmistakably resorted to nineteenth century work ethic reasoning as she went on to say: -

The rationale underlying these changes is essentially the dogma that everyone ought to be able to have a job and if they do not it is proof that either they are lazy or the benefits are too good! ${ }^{5}$

The Employment Contracts Act, which abolished compulsory unionism and the centralised wage award system, was also part of the package aiming at change to the welfare state. Richardson saw the Act as the best hope for a speedy return by the unemployed to the workforce, ${ }^{86}$ but, enacted at a time of serious economic trouble, its declared intentions of promoting an efficient labour market, in reality exacerbated the social and economic distress of many, ${ }^{87}$ as vulnerable workers became susceptible to coercion by employers. ${ }^{88}$

Apparently contradicting its own election slogan, the National Government relentlessly

${ }^{85}$ Cited by St John, ibid

${ }^{86}$ Richardson, Address..., 27 March, 1991

87 Walsh, Pat, The Employment Contract Act, in Boston \& Dalzeil, (eds), p. 75

88 Dannin, Ellen J., Working Free. The Origins and Impact of New Zealand's Employment Contract Act, p. 243 
pursued these policies which to most people seemed inconsistent with claims of "creating a decent society". The broken promises, failure to indicate planned social reforms,${ }^{89}$ and the lack of public consultation, led within a year to a drastic drop in public support for the Government, and a general cynicism of the whole political system. ${ }^{90}$

Rather than encouraging harmony and social cohesion, National's policies have produced greater conflict and strife.... National has intensified the degree of social stratification.... National has created greater insecurity.....National's policies have generated greater inequality and growing poverty. Indeed, not since the Great Depression has New Zealand witnessed such evidence of social deprivation and hopelessness, nor such high levels of unemployment..$^{91}$

Few it seems agreed with Richardson's belief that Together, our welfare and labour market reform will transform a dependency culture into an enterprise culture. ${ }^{92}$ Rather, critics pointed to what they saw as National's abandonment of,

any commitment to an egalitarian society, let alone a further extension of citizenship rights. On the contrary, important values such as human dignity, distributive justice, and social cohesion, have been given second place to the pursuit of efficiency, self-reliance, and fiscal balance, and a more limited state. $^{93}$

By September 1992 a national survey indicated that half of those polled thought New

${ }^{89}$ Bolger, p. 115, comments however, that National did state its intention of redefining the welfare state during the 1990 election campaign.

${ }^{90}$ Boston \& Dalzeil, (eds), pp. x-xi

91 ibid, p. viii

92 Richardson, Address..., 27 March, 1991

${ }^{93}$ Boston \& Dalzeil, (eds), p. ix 
Zealand was heading down the wrong path. ${ }^{94}$ The years of change, under first the Labour Government, and then the National, had resulted in devastating social impact, which seemingly had been ignored by both Douglas and Richardson. Neither of them, it was commented, showed any visible concern for the human cost of this huge and risky experiment. ${ }^{95}$

There were of course, those who did support the government's policies. ${ }^{96}$ Colin James refers to a quiet revolution which, during the years 1984-92, overthrew the established institutions and holders of power. ${ }^{97}$ That social group of elite individuals who had quietly started to edge their way into control during the Muldoon era had by 1992 replaced a generation whose traditions were rooted in the depression, in politics, the bureaucracy and business. Among them were entrepreneurs who profited from the deregulated economy, some who became immensely rich, and yet others whose occupations flourished as a result of the economic strategies. ${ }^{98}$ Certainly for one section of the population the rapid change sweeping the country meant more personal freedom

${ }_{94}$ Kelsey, Jane, The Anatomy of a State in Crisis, in Sharp (ed), p. 189. Other surveys conducted by Jack Vowles and Peter Aimer for their book Voters Vengeance, had shown that between 1987 and 1990 the percentage of people who felt the government (Labour) was heading the country in the right direction, had dropped from $73 \%$ in 1987 to $40 \%$ in 1990. (p. 80) A question in 1990 relating to the issues of inflation and unemployment, indicated that $70 \%$ of those surveyed believed it was more important to get unemployment down than inflation. (p. 82)

95 ibid, p. 186

$9638 \%$ according to the 1992 survey thought the country was on the right track. (ibid, p. 189) This is a significant proportion.

97 James, (1992), p. 276

98 ibid, p. 183 
and independence, and a state less directive and less concentrated on a collective purpose. ${ }^{99}$ Douglas commented as early as 1987 , that it was surprising how rapidly New Zealanders had adjusted to the changes thrown at them through restructuring.

What is strange and interesting is that no one gets excited any more. People now seem to view change as normal and take it more or less for granted. For a country that has been cosseted by several decades of governments from the influences and adjustments of the real world, this rapid adaptation is both surprising and important. ${ }^{100}$

Douglas ignored the fact that the stress of constant change makes people more willing to accept change as a way of actually coping with the tension, not understanding that, a contented people is difficult to mobilise for change; a worried, destabilised, fearful people is much more likely to let past, tolerate or even welcome change. ${ }^{101}$

For many however, the changes meant insecurity, fear and misery. The reforms welcomed by some, for others had the horrendous impact of a meteor impacting from outer space ${ }^{102}$ From a situation of full employment in which fear of being dismissed from one's job was not an issue, and workers felt free to not only show indifference about their jobs, but to change jobs as the mood struck them, ${ }^{103}$ people were thrust into an environment of high unemployment where $10.5 \%$ of the workforce were jobless. ${ }^{104}$

99 ibid, p. 278

100 Douglas, p. 93

101 James, (1986), p. 10

102 Randerson, Richard, (1992), Hearts and Minds. A Place for People in a Market Economy, p. 72

${ }^{103}$ Eldred-Grigg, (1990), p. 173

${ }^{104}$ New Zealand Official Yearbook, 1993, p.272 
Statistics for 1991 show that the majority of unemployed were unskilled with either few, or no school qualifications, ${ }^{105}$ and tended to be Maori or Pacific Islanders, the disabled, women, or young, ${ }^{106}$ making it is clear that lack of work, and the government reforms, punished some sections of society more than others. The dreams of prosperity that had buoyed up the working classes during the years of full employment were dashed, and the stratification of New Zealand society, denied for so many generations, became a harsh reality, particularly as poverty reared its head for the first time since the Great Depression. ${ }^{107}$

According to one commentator, Phillida Bunkle, the theoretical misconception which appears to have been held by the free-marketeers in the governments during this time, was a simplistic psychology that naïvely assumes that it is lack of motivation which keeps people poor. ${ }^{108}$

It assumes that this problem of motivation can be overcome by making them poorer. The rich on the other hand have to be made enormously richer to maintain their motivation.

The theory is that dividing society into winners and losers will unleash the entrepreneurial aspirations of the losers. ${ }^{109}$

In reality it was the poor, whether they were unemployed, or other beneficiaries on the

105 ibid

${ }^{106}$ Eldred-Grigg, (1990), p. 173

107 Dunstall, in Oliver \& Williams, (eds), p. 421, states that poverty actually was rediscovered at the end of the 1960 s as unemployment figures began to move upwards.

${ }^{108}$ Bunkle, Phillida, People Matter More Than Profits, Accent, Vol. 3, No. 1, February 1988, p. 15

109 ibid. 
welfare system, who took the brunt of the economic restructuring. The likelihood of any entrepreneurial enterprises emerging among the poor was fairly remote, given that: -

Faced with a daunting combination of unemployment, benefit cuts, enforced dependence, and user-part charges, they were free to choose whether to use their scarce resources to buy housing, health, education, or other essentials like food - and which of those essentials to do without. ${ }^{110}$

What politicians, economists, and many "ordinary" New Zealanders chose to ignore was that the repercussions of unemployment and poverty were not simply about consumer spending and lack of income, but frequently involved serious psychological consequences as well, including ill health and even suicide. ${ }^{111}$ In other instances, whatever drive remained in those who were unemployed and demoralised, was turned to crime, not imaginative legitimate fiscal enterprise. ${ }^{112}$

Such apparent "weaknesses" raised the old adages of the "respectable and deserving poor" on one hand, and the "disrespectable and undeserving poor" on the other, ${ }^{113}$ accompanied by the re-emergence of the basic myth that the poor and unemployed had contributed to their situation through mismanagement or because they had not tried hard enough to get work. ${ }^{114}$ To be poor, and/or unemployed in New Zealand in the $1980 \mathrm{~s}$ was to all intents and purposes to demonstrate deviant behaviour, totally at variance with

${ }^{110}$ Kelsey, in Sharp, (ed), p. 189

111 Easton, Brian, The Personal Responsibility of an Economist, in Pelly, Raymond, (ed), Towards a Just Economy, pp. 15-16

112 ibid, p. 16; Bunkle, p. 15

${ }^{113}$ Eldred-Grigg, (1990), p. 196

114 Bryant, George, (1979), The Widening Gap. Poverty in New Zealand, pp.2-3 
the still fresh memories of full employment, ${ }^{115}$ and the values of the new breed of politicians - enterprise, self-reliance, rewards for the successful. ${ }^{116}$ The ethos of work so long part of the New Zealanders' psyche was blatantly threatened by the monetarist policy of Rogernomics, but it has been suggested that it was this very commitment to the work ethic that made it relatively easy for the politicians who were ultimately responsible for the problem, to divert attention away from their own inability to recreate the conditions of full employment ${ }^{117}$ by portraying the jobless as "dole bludgers."

In her study on the way the media presented the issue of unemployment during the 1980 s, Shirley Leitch comments that the majority of news stories which characterised the unemployed as "bludgers" disturbingly came from the Departments of Social Welfare and Labour, and their Ministers prior to 1983, and from the Minister of Employment after the election of the Labour Government. ${ }^{118}$ For example, Jim Bolger as Minister of Labour under the National administration, is quoted in several news stories in March, 1982, as having taken action against the long-term unemployed, ${ }^{119}$ whom he believed sought to make a career out of being unemployed. ${ }^{120}$ Leitch makes the observation that having raised the bogey of the dole bludgers ${ }^{121}$ politicians such as Bolger, then almost

115 Leitch, p. 88

116 Randerson, (1992), p. 9

117 Leitch, pp. 88-9

118 ibid, p. 89

119 At that point 26 weeks was regarded as "long-term." (ibid)

120 ibid

121 ibid 
always followed up their statements with a rider acknowledging that such aspersions against the unemployed were not pertinent to all those without work. The initial indictments against the unemployed could then not be disproved Leitch claims, ${ }^{122}$ but despite attempts made to soften the taint, it was the "bludger" label that people remembered.

Clearly it was much easier for governments to blame the victims of their policies than to take responsibility for the results of their faulty economic models. The National Government of the early 80 s for instance, was unused to, and highly suspicious of, the unemployed, ${ }^{123}$ publicly labelling them as parasites living on the tax payers money (ignoring that beneficiaries also paid tax), ${ }^{124}$ and setting up squads to check on the legitimacy of beneficiaries. ${ }^{125}$ Suspicion at such a high level by the state helped to discredit the unemployed in the eyes of the public and built on the "bludgers" image, while insinuations from Douglas and others under the Labour administration, that workers without jobs had only themselves to blame because they were not moving fast enough into newly expanding industries, ${ }^{126}$ further encouraged the impression that all unemployed were lazy and unwilling to find jobs. A constant theme of Bolger's National Government was that unemployment was a state within the control of the individual and that those on [the dole] were only "bludgers" who needed to be urged back into gainful

122 ibid

${ }^{123}$ McClure, p. 161

124 Leitch, p. 93

125 ibid. Leitch says that the Labour Government kept up the use of these squads.

${ }^{126}$ Collins, Simon, p. 113 
employment. ${ }^{127}$ During the space of a decade all the old nineteenth century aphorisms reappeared to haunt the luckless unemployed, encouraged by politicians who had pledged themselves to some allegedly immutable economic law. ${ }^{128}$ Rather than look to their own strategies, the post-1984 politicians blamed, nagged, and berated New Zealanders, employed and unemployed alike, for their own misfortunes, describing them as cringing supplicants begging from the state, claiming that their work ethic, initiative and independence had been sapped by the welfare state. ${ }^{129}$

In an attempt to restore these three crucial values, training schemes for unemployed, unskilled workers were devised by the Labour government, ${ }^{130}$ with suggestions made by some that those unwilling to participate in training should be financially penalised as punishment, ${ }^{131}$ or made to work for their dole. The attitude of the property magnate Robert Jones, for example, was not uncommon. In 1988 he wrote: -

we have 100,000 largely useless people wallowing about living off the rest of us. To resolve that we should forthwith stop paying the dole and offer low paid Government employment as manual workers (there's heaps to be done) hand in hand with subsidies to employers prepared to train tradespeople. ${ }^{132}$

127 Dannin, p. 161

${ }^{128}$ McLauchlan, Gordon, (1992), The Big Con. The Death of the Kiwi Dream, p. 9

129 ibid, p. 12

130 Collins, Simon, p. 113

131 Crocombe et al, p. 174

132 Jones, Bob, Wimp Walloping, p. 86. His comments reflect the 1930 s policy of no pay without work. 
Later that year, a small group of those "largely useless people" set out to march from $\mathrm{Te}$ Hapau in the far north to Wellington, as a protest against unemployment and the cuts made in Maori Access Training. One of the march organisers, Bill Bradford, is quoted as saying that whereas a year before they would have been labelled "dole bludgers", the fact that the public had lost faith in Labour's employment policies was behind the support they received during the march. ${ }^{133}$ They certainly got media attention but how much real sympathy there was for their cause is hard to determine. Undoubtedly however, the march did draw the issues involved to the country's notice, and people from all walks of life and from all backgrounds joined in the march for short distances as a mark of their support. Chants such as Us now, you next, ${ }^{134}$ must have been chilling for those New Zealanders yet untouched by the economic restructuring but aware of the threat of unemployment possibly confronting them.

The alternative image to "dole bludger" granted to the unemployed was that of victim. ${ }^{135}$ Voluntary agencies, community workers and social scientists in particular, identified unemployed people as the innocent and powerless victims of an economic system which was ruthless and heartless. ${ }^{136}$ The media, which so heavily influenced people's opinions, occasionally published stories which presented the unemployed person as a victim of hard economic times. For example, The Evening Post, wrote a story about a farm

133 Collins, Jane, A long hard road for the unemployed, Evening Post, 1 November, 1988, p. 7

134 ibid

${ }^{135}$ Leitch, p. 97

${ }^{136}$ ibid, p. 98 
worker on the unemployment march mentioned above. He had contracted an agricultural related disease which had genuinely prevented him from working for two months and had resulted in him being sent down the road by his boss. ${ }^{137}$ At the time of the march he had been out of work for twenty months, despite many efforts to find work. $^{138}$

Meanwhile he does voluntary work for local groups because "I can't stand sitting around, " he says. He hopes to set up an employment agency and a carpentry Access [training] module in Wellsford to help himself and other unemployed. ${ }^{139}$

Here was an example of an unemployed person showing entrepreneurial aspirations, ${ }^{140}$ a man who had been made unemployed through the unjustness of an individual employer, and who had tried to get work to no avail. Yet even in this story, which gives the impression of being relatively sympathetic, are two instances which illustrate the bias towards the unemployed. This farm worker had resisted pressure to move to Auckland because he says he suffered a nervous breakdown as a result of city living. ${ }^{141}$ Somehow in these few words the suggestion is made that here is man with a weakness. Maybe his unemployed state is a result of some personal pathology, not the consequence of the economic downturn in rural areas? Unspoken words, but as Leitch points out in her study, personalising individuals as dole bludgers or victims gave the news media

137 Evening Post, 1 November, 1988, p. 7

138 ibid

139 ibid

${ }^{140}$ Kelsey, in Sharp, (ed), p. 189. See earlier quote.

${ }^{141}$ Evening Post, ibid. The emphasis is mine. 
leeway to blame some of them for their own plight. ${ }^{142}$

In the second instance the farm worker is quoted as having said that: -

going on the benefit had made him realise how low farm wages were. On unemployment benefit with an accommodation allowance he receives just over $\$ 300$ a week, whereas working on the farm he received $\$ 239$ in the hand, including family support. ${ }^{143}$

The suggestion that being on an unemployment benefit was more advantageous than being in work, played into the hands of the free-market campaigners who were not only questioning, but rapidly abandoning, the principle of the welfare state. Arguments that assistance moved people into dependency and into poverty traps ${ }^{144}$ were beginning by the late eighties, to become commonplace, and the second term of the Labour Government was witnessing a shift in the balance between the competing interests of welfare and capitalism. ${ }^{145}$ The increasing state expenditure on social services due to unemployment in particular, was leading to a focus on the amount beneficiaries were being paid, hence the media emphasis in this story. The farm worker may have been a "victim of unemployment" but that he should be earning more on a benefit than through working simply proved to many that there was something amiss with the welfare system. ${ }^{146}$

${ }^{142}$ Leitch, p. 98

143 Evening Post, ibid

${ }^{144}$ Douglas, p. 244

${ }^{145}$ Koopman-Boyden, Peggy G., Social Policy: Has There Been One?, in Holland \& Boston, (eds), p. 213

146 The Business Round Table for example, in its statement Unemployment. Realities and Illusions, published in 1990, while making observations which demonstrated some 
The lessening of the responsibility of the welfare state was an international phenomena by the late 1980s, with British, American and Australian administrations, as well as New Zealand, all questioning the premises on which the concept of the welfare state had been based. In New Zealand the notion of a system which protected people from poverty and isolation, provided social well-being, and the right of everyone to belong and participate' in a common society and its pleasures, was viewed by supporters of Rogernomics, and later Richardson's policies, as a romanticism of welfare, ${ }^{147}$ and as no longer sustainable in a time of economic recession. The overload on the welfare system as social stress and unemployment climbed, led Douglas to basically abandon the principle of the welfare state on the grounds that the country could no longer afford it. A new emphasis was placed on the targeting of benefits to help only those in real need, incentives were introduced to get beneficiaries off welfare and back into the workforce, and there was a determination that any assistance must be efficient. ${ }^{148}$ When the report of the Royal Commission on Social Policy was released in 1987 it was able to state that $68 \%$ of those questioned supported the proposition that people should have to look after themselves more with less help from the Government, ${ }^{149}$ demonstrating that a significant proportion of the population were beginning to see social security as detrimental to personal incentive.

understanding that unemployment was an economic problem and due to the restructuring of the system, also made it clear that it was concerned that the unemployed would be discouraged from seeking work if social welfare benefits were badly designed and poorly targeted. (p. viii) BRT thought it highly unlikely that a worker would seek out lowly paid work on an assembly line if the pay was going to be less or little more, than the dole.(ibid)

147 McClure, p. 234

148 Collins, Simon, p. 97

${ }^{149}$ Cited in Collins, Simon, p. 239 
The National Government of the early nineties promoted a concept of self-reliance, and strongly encouraged involvement in the workforce, expanding on the movement of the eighties towards reshaping the welfare state. Highly critical of the dependency encouraged by the old welfare system and the cost involved in administering it, Richardson declared, too many New Zealanders still float in a dream time world that has the good life as a matter of right, where Government's capacity to guarantee this good life is unlimited. ${ }^{150}$ Only a matter of a few days later she went on to disclose: -

Things will change because the Government will change the rules to change the attitudes. And so we are redesigning the Welfare State. Switching it back to helping those in real need not serving up as an entitlement. ${ }^{151}$

In contrast to traditional attitudes towards a welfare state established in affluent times and supported by full employment, the National Government invoked a renewal of the work ethic, calling upon a memory of an earlier New Zealand where industry, independence and perseverance were commonplace. There was a regression to the philosophical principle that work must receive a different reward from non-work, and that nonworkers should not be entitled to the same experiences and quality of life as workers. ${ }^{152}$ In cutting benefits the Government was indicating which activities it saw as having value, and what sort of lives it wanted New Zealanders to lead. The quicker we all grasp that life, as we want it, must be based on a strong working ethic, and excellence, the faster it will happen, Richardson told the country in her 1991 State of

${ }^{150}$ Richardson, Address..., 27 March, 1991, p. 3

${ }^{151}$ Richardson, State of the Nation Speech, 3 April, 1991, pp. 6-7

${ }^{152}$ McClure, p. 234 
the Nation Speech. ${ }^{153}$

The Employment Contracts Act which was designed as part of this package to encourage a stronger working ethic, was expected to encourage fresh thinking in respect of the responsibility of individuals and our determination to ensure that individuals had an incentive to stand on their own feet and get ahead. ${ }^{154}$ Certainly the Select Committee's hearing on the Employment Contracts Act in 1993, noted that as a result of the Act, the average worker was experiencing an intensification of work, ${ }^{155}$ but this was due more to a deterioration in working conditions than an increase in individual incentive. ${ }^{156}$ Many workers were being press-ganged ${ }^{157}$ into accepting a lowering in wages and longer working hours, ${ }^{158}$ on the basis that jobs were hard to find, and resigning from their jobs meant a 26 week stand down before they were entitled to an unemployment benefit which was then even lower than their wage rates. ${ }^{159}$

This fear of unemployment as a prime motivator for many workers was not new. Before the Employment Contracts Act was even mooted by the National Government, the

153 Richardson, ibid, p. 8. Emphasis mine

154 Richardson, cited in Dannin, p. 161

155 Dannin, p. 173

156 ibid

157 ibid, p. 108

158 ibid, pp. 108, 173

159 ibid, p. 108 
Second New Zealand Sweating Commission had already reported in 1990 that many witnesses....testified that the intensity of work had increased in recent years. ${ }^{160}$ While the Commission was specifically investigating the effects on retail workers of the deregulation of shop trading hours, its findings can be said to reflect the consequences of New Zealand's economic restructuring. Workers, the Commission stated, were finding it almost impossible to resist changes in hours and working conditions, ${ }^{161}$ and were driven by the overriding fear of unemployment [which] forces them to accept the degrading treatment to which they are so often subjected. ${ }^{162}$ The question needs to be asked whether an "intensification" in work due to fear of unemployment, in reality, equated to meeting the National Government's objective of increasing the work ethic?

However, it seems reasonable to suggest, that given the revolutionary changes in the economic and welfare systems over the period of 1984-92, many New Zealanders, regardless of their opposition, were woken from their slumbers of the full employment, welfare driven years, and thrust into a work-oriented society where citizens were expected to gain a sense of self-reliance and personal responsibility through hard work and independence from the state. While it has been stated that in 1992

many New Zealanders remained wedded to a strongly interventionalist state, universal provision of state-funded social welfare, and state ownership of strategic resources administered to meet both commercial objectives and social needs, ${ }^{163}$

${ }^{160}$ Second New Zealand Sweating Commission, Across the Counter: The Lives of the Working Poor in New Zealand 1990, p. 13.

161 ibid, p. 31

162 ibid, p. 36

163 St John, in Sharp, (ed), p. 190 
there was also a burgeoning recognition that the adjustments that had been made had been largely necessary. ${ }^{164}$ The success or failure of the Labour and National administrations to revitalise the work ethic of earlier years through their policies remains to be judged.

164 James, (1992), p. 189-90 


\section{CHAPTER 6}

\section{The pursuit of an ideal - a market-driven public service}

Symbolic of the revolutionary changes in the economic system in New Zealand between 1984 and the early nineties, was the reform of the public service. Demands for increased accountability and efficiency within the public service ran parallel to demands for an increased work ethic in the wider community. While for some, the changes in the public sector were an indication of New Zealand's growing maturity as a developed nation, evidence that New Zealand was moving into a stage of consolidation in which administrative and management structures appropriate to an independent nation could be implemented, ${ }^{1}$ for others the overhaul was a demonstration of government recognition that efficiency and productivity in the state sector were only possible if it was no longer sheltered from the normal pressures of the economy. ${ }^{2}$ There were yet others who saw the changes which occurred as being in line with those experienced in other western countries where bureaucracy was being attacked, ${ }^{3}$ or a results - rather than process - oriented administrative ethos ${ }^{4}$ was being advocated. Certainly sweeping changes were implemented in New Zealand, not necessarily because of doctrinaire beliefs concerning the role of the state, but rather, as part of the government's

${ }^{1}$ Martin, John \& Harper, Jim, (eds), Devolution and Accountability, p. v

2 O. E. C. D. Economic Surveys, New Zealand 1988/89, p. 49

${ }^{3}$ Alley, R. M., (ed), State Servants and the Public in the 1980s, p. 7

4 Gregory, Robert, The Reorganisation of the Public Sector. The Quest for Efficiency, in Boston, Jonathan \& Holland, Martin, (eds), The Fourth Labour Government. Radical Politics in New Zealand, p. 119 
programme to reduce the fiscal deficit ${ }^{5}$ and its commitment to a market-led reform of the economy. ${ }^{6}$

Influenced by the emergence of monetarist thinking that was committed to the market as the preferential means of distributing resources, instead of the state ${ }^{7}$, the Labour Government set about restructuring the public service in profound ways. Jonathan Boston, one of the most prolific commentators on public policy during the period, wrote: -

Between 1984 and 1990 New Zealand's public sector underwent massive structural, organizational, and management changes. At the central government level these included the corporatization and subsequent privatization of state trading activities, the introduction of a new financial management regime, major changes to the machinery of government, a new system of appointing and recuperating senior public servants, substantial cuts to public sector industrial relation practices, a growing emphasis upon biculturalism and employment equity, and a much greater concern with accountability and performance assessment. ${ }^{8}$

In only a matter of a few years, the Government assigned to memory the unified career service which had remained unchanged, to all intents and purposes, since 1912.

This is not to say that the public service in New Zealand had not faced changes before. As early as the 1880 s depression politicians had targeted the cost of government

5 Martin, John, (1988), A Profession of Statecraft? p. 4

${ }^{6}$ Gregory, p. 119

7 Britton, Steve, Le Heron, Richard, \& Pawson, Eric (eds), Changing Places in New Zealand. A Geography of Restructuring, p. 164

${ }^{8}$ Boston, Jonathan, The Theoretical Underpinnings of Public Sector Restructuring in New Zealand, in Boston, Jonathan et al. (eds), Reshaping the State. New Zealand's Bureaucratic Revolution, p. 1 
administration by appointing a Royal Commission whose brief was to reorganise the public service and cut costs without losing efficiency. ${ }^{9}$ The Commission's chairman, Alfred Saunders, was to later write: -

the Commission discovered an incredible amount of careless neglect, of wanton waste, of useless expenditure, of wilfully blind inspections, of criminal appointments, of systematic fraud, and of successful, long continued robbery....The facts brought to light by the fearless and searching investigations of the Civil Service Commission were so startling, and so difficult to believe, that even the Government was unwilling to believe them. ${ }^{10}$

Despite Saunders' diatribe the only evident action taken by the Commission was to cut salaries by $10 \% .^{11}$ Instead the Governments of the late nineteenth century actually created new departments, ${ }^{12}$ and increased the number of civil servants as one way of influencing the labour market and countering unemployment. ${ }^{13}$ By 1909 the civil service had grown to 37 departments, and the government, in the interests of economy and efficiency, ${ }^{14}$ not very successfully regrouped the departments into sixteen supposedly more manageable groups. Within another three years it was clear that the reorganisation had not worked, ${ }^{15}$ and it became increasingly obvious that New Zealand's state service

${ }^{9}$ Polaschek, R. J., Government Administration in New Zealand, p. 32

10 ibid, p. 33, citing Saunders, who published a History of New Zealand, in 1899.

11 ibid

12 ibid, p. 34

13 Thomson, David, A World Without Welfare. New Zealand's Colonial Experiment, p. 117

${ }^{14}$ Polaschek, p. 37

15 ibid 
needed to be structured in a more orderly way. ${ }^{16}$ Not only was the civil service far too cumbersome, but knowing that corruption and patronage were rife, there was a general lack of public confidence in the whole government administration system. ${ }^{17}$

The Royal Commission, known thereafter as the Hunt Commission, which was established in 1912 to report upon the public service, not only led to the categorisation of the numerous departments into four distinct divisions (administrative, professional, clerical and general), ${ }^{18}$ but also removed from Government ministers the power to appoint, promote, terminate, discipline and fix pay rates,${ }^{19}$ and appointed a Public Service Commissioner to prevent any further corruption. ${ }^{20}$ A career service ${ }^{21}$ was created, free of political patronage, and founded on the concept of progression from cadet to permanent head..$^{22}$ In its basics, this hallmark $k^{23}$ of the public service, fundamentally remained untouched until 1985 .

Like the moves in the 1880 s, attempts in the early 1930 s by the depression Coalition

${ }^{16}$ Roberts, John, Politicians, Public Servants and Public Enterprise, p. 26

17 Probine, M., People, Management and the Management of Change, in Harris, A. C. (ed), Human Resource Management in Public Administration: Te Whakahaere-a - Iwi mo te Katoa, p. 71

18 Roberts, p. 26

19 Probine, p. 71

20 ibid

21 ibid; 1962 Royal Commission of Inquiry, The State Services in New Zealand, p. 9

${ }^{22}$ Martin, (1988), p. 14

23 ibid 
Government to reorganise the public service, did not stem from any aspiration to improve administration, but were a consequences of economic crisis, ${ }^{24}$ and were to be rapidly overtaken by the introduction of the welfare state by the Labour Government in 1935. The next ten years saw an expansion ${ }^{25}$ of the civil service as politicians and public servants regulated the economy of the welfare state, although there is an indication that some effort was made between 1946-54 to decrease and regroup the number of departments into a more compact administrative system. ${ }^{26}$ However, because the public service operated from what has been described as,

the shared assumptions of the community: the consensus about the welfare state, Keynesian economic management, the priority of full employment, and a positive view of state intervention to cope with market and social failure ${ }^{27}$

it was difficult to justify any serious suggestions about reorganisation when there were no political rewards to be anticipated. ${ }^{28}$ As Polaschek observed as early as 1958 in his study on Government Administration in New Zealand, there was little likelihood of restructuring unless the service failed to deliver in some major way, or until adverse economic conditions make the need for improved administration more apparent than

${ }^{24}$ Polaschek, p. 43. It is interesting to note that the 1985-92 restructuring which finally took place was itself a consequence of economic crisis.

25 ibid, p. 49. There were 53 departments by 1945 . The 1962 Royal Commission also comments on the steady growth in numbers of public servants from the mid-thirties to the early sixties, attributing the increases to the need to staff social and development programmes enlarged to meet the needs of a growing population.(p. 20, paragraph 51)

${ }^{26}$ Polaschek, p. 53

${ }^{27}$ Martin, (1988), p. 2

${ }^{28}$ Polaschek, p. 55 
it is at the present time. ${ }^{29}$

The primary concern facing the public service in the 1950 s was initially not one of structure, but one of personnel management. Problems related to pay fixing, which included major issues regarding equal pay for female state servants, were particularly pressing, ${ }^{30}$ but gradually over the decade a broad-based call by the New Zealand Institute of Public Administration for a review of the whole structure of the public service, became increasingly insistent. The NZIPA pointed out that: -

Since the Hunt Commission of 1912....the functions of government in New Zealand had been changed 'almost out of recognition.' But the associated structural changes had been made 'piecemeal', producing a result 'that was never consciously designed and has never been comprehensively reviewed. ${ }^{31}$

Demands for a review were finally met in 1961-2, with a second Royal Commission of inquiry into the state services. ${ }^{32}$ The McCarthy Commission, as it became known, was given broad terms of reference which encompassed the organisation, staffing, and methods of control and operation of Departments of State. ${ }^{33}$ The report which was released in 1962 in general endorsed the existing system, but did begin to recognise that

29 ibid

30 Henderson, Alan, The Quest for Efficiency: The Origins of the State Services Commission, p. 281

31 ibid

32 ibid, p. 287

33 ibid, p. 288 
there were obvious concerns about the size $e^{34}$ and efficiency of the service. ${ }^{35}$ In examining the problems facing the state services, the Preface to the report in particular, acknowledged the changing environment of the early sixties, including social, educational, technological, economic and political developments. ${ }^{36} A$ constantly changing environment calls for a continual process of review, ${ }^{37}$ the report stated, but it also cautioned against drastic administrative surgery as the best means to attain change. ${ }^{38}$ The Commission remarked, perhaps naïvely,

In the long run, more can be accomplished by encouraging a satisfactory pattern of growth than by relying on periodic operations to remedy the defects of haphazard development. ${ }^{39}$

While the Prime Minister of the time endorsed the Commission's Report and its recommendations, some media comments indicated that there were those who believed that drastic action might be preferable to the gradual structural change recommended by the Commission, and there was one politician at least, who was disappointed that more detailed changes in the machinery of government administration were not promoted. ${ }^{40}$

341962 Royal Commission, p. 20. In 1912 there were 4,641 state servants; by 1961 the numbers had increased to 61,993 - for some reason (unexplained) these figures did not include those working in the Post Office, railways or legislative section of the service.

35 ibid, p. 9, paragraph 6

36 ibid, p. 1

37 ibid, p. 10, paragraph 10

38 ibid, p. 5

39 ibid

${ }^{40}$ Henderson, p. 297 
The principal result of the Commission's findings was the 1962 State Services Act which established a State Services' Commission with similar functions to the former Public Services' Commissioner, while widening the brief of responsibility to provide assurance of the efficient and effective management of the service. ${ }^{41}$ It was not many years before the new Commission, along with the Treasury, and government departments, found itself wrestling with problems of greater management accountability, ${ }^{42}$ especially as widespread questioning regarding financial management, information procedures, corporate planning, the definition of departmental missions, ${ }^{43}$ and the true extent of state activity, became more commonplace. ${ }^{44}$ The National Government of the time, however, showed little interest in public sector reform. ${ }^{45}$ Apart from what Colin James describes as crude mechanisms such as a 'sinking lid' on staff members.... and acrossthe-board $3 \%$ cuts, ${ }^{46}$ little real action was taken, although the general public was probably duped into believing that terms like staff ceilings and sinking lid meant the public service was shrinking. ${ }^{47}$

Despite the Government's seeming disinterest, the issues facing the public sector were,

41 Probine, p. 71

42 Roberts, p. 35

43 ibid, p. 35

44 Martin, John, (1990), Remaking the State Services, in Holland, Martin \& Boston, Jonathan, (eds), The Forth Labour Government. Politics and Policy in New Zealand, p. 123

45 Martin, (1990), p. 123

46 James, Colin, (1992), p. 161

${ }^{47}$ Henderson, p. 332 
nevertheless, recognised in some quarters as being significant in light of the changing environment of the late 70s. The New Zealand Planning Council, for example, noted that the issue of management in the public sector was assuming importance as a component of the broader problems facing the country during a time of slow growth, and the Secretariat Director of the Council, Ken Piddington, wrote: -

One often worries that as an institution the public service may find it very hard to adjust to the changes which New Zealand is going to face. It will be handicapped by those very features which have been deliberately built in to ensure stability, impartiality and proper financial controls. Having inherited its professional ethic from the circumstances of Victorian England, ${ }^{48}$ the New Zealand public service now has to rethink those principles against the needs of a different society in a different age and with an increasingly different political and administrative framework. ${ }^{49}$

It became increasingly evident as a psychology of change began to sweep New Zealand in the late $70 \mathrm{~s}$ and early $80 \mathrm{~s}$, that the public service, along with the rest of the country, was going to have to come to terms with New Zealand's new circumstances. ${ }^{50}$ As

48 In his book The Call to Seriousness. The Evangelical Impact on the Victorians, Ian Bradley makes the claim that the development of a professional civil service in England in the nineteenth century was characterised by Evangelical principles such as "integrity, impartiality and unflinching application to duty". (p. 160-1) The Evangelicals decried the "aristocratic personnel and principles" (p. 161) of the old model of the civil service and instead called for a service made up of middle class persons steeped in the virtues of industry, respectability and integrity. The ethic of the professional public service, Bradley claims, was based on the ideals of the middle class Evangelical civil servants who made up the bulk of the British public service in the late nineteenth century. (p. 162-3) The British concept of civil service was introduced to New Zealand at the time of colonisation, ( Henderson, p. 9) and I believe it is relatively safe to assume that the ethics of the colonial public service were also founded on its British counterpart.

49 Piddington, Ken, The Public Service in the Post-Victorian Era, Public Sector, Vol. 1 (2), Spring, 1978, p. 4

${ }^{50}$ Holmes, Frank \& Piddington, Ken, The Public and its Servants: The New Zealand Environment Re-assessed, in Alley, p. 50 
conjecture about the necessity for a new approach to the nation's economic management was fostered, similar speculation occurred regarding the need to examine the efficiency and accountability of the public service. The problems in the public sector were in many ways reflections of those in the wider economic arena, ${ }^{51}$ and in the wave of reform that overwhelmed New Zealand at all levels from 1984, it was inevitable that the state services would be targeted. ${ }^{52}$

One of the predicaments facing the civil service in the revolutionary days of the $80 \mathrm{~s}$, other than the obvious issues of efficiency and accountability, was the image of the public servant as a pampered, ${ }^{53}$ faceless bureaucrat, ${ }^{54}$ often performing nonessential work, $^{55}$ and ridiculously overpaid. ${ }^{56}$ The dutiful, diligent public administrators ${ }^{57}$ produced by the 1912 Public Service Act were now frequently figures of derision in the

${ }^{51}$ Deane, Roderick, Public Sector Reform: A Review of the Issues, in Clark, Margaret \& Sinclair, Elizabeth, (eds), Purpose, Performance and Profit. Redefining the Public Sector, p. 15

52 Douglas, p.134, observed that while the changes in the public service between 1985-7 proceeded at a pace probably never experienced before in its history, he believed this quite reasonable considering what was happening elsewhere in the economy.

53 Alley, p. 7

${ }^{54}$ Holmes \& Piddington, p. 50

${ }^{55}$ Fairburn, A. R. D., A Nation of Officials, in The Woman Problem and Other Prose, p. 46. Frank Sargeson, as early as 1937 , wrote a parody on the non-essential work of the public service where Life was files. You didn't know what they were about. You kept on carrying them. Endless files to carry. Files. Files.(In the Department, The Stories of Frank Sargeson, p 57)

56 Jones, Bob, New Zealand the way I want it, p. 149

${ }^{57}$ Roberts, p. 36 
media, ${ }^{58}$ while the state service itself was branded as a repository for people seeking $a$ soft, secure job for forty years. ${ }^{59}$ Assertions made by Fairburn in his essay A Nation of Officials in the late $60 \mathrm{~s}$, were still indicative of the public's view of public servants almost two decades later. Unfair as such characterisations may have been, they were a not uncommon perception.

We all know the sort of man who is quiet a decent fellow until he gets a bit of power into his hands - the petty bureaucrat. His character deteriorates, and he becomes officious and insufferable. There are other men who, when they become part of a governmental machine, lapse into sloth and indifference.....Bureaucracy encourages many of the vices of human nature laziness, arrogance, love of power, officiousness and other such traits. It does little to bring out the virtues. ${ }^{60}$

As late as 1990, even after several years of public sector reform, a Sunday newspaper columnist was still demonstrating considerable contempt for the traditional public servant. While commenting on unemployment, he wrote: -

Reform of the state sector has eliminated thousands of "positions" that passed for jobs but in fact produced nothing. The people in those positions, in organisations like the Post Office, the railways and Air New Zealand, felt as if they had jobs, but they were mistaken. They were the beneficiaries, and finally the victims, of a vast featherbedded inefficiency which this Government to its eternal credit, is obliterating.... So what were these people doing? With the best will in the world, they were producing literally nothing. They were getting wages and salaries for being unemployed. ${ }^{1}$

58 Alley, p. 8; Roger Hall's popular play "Gliding On" about a stereotype government department added to the ridicule, especially when it was recast as a television series.

59 Von Tunzelmann, Adrienne \& Johnston, Jeanette (eds), Responding to the Revolution. Careers, Culture and Casualties, citing Geoffrey Palmer's opening speech at the 1987 proceedings of the New Zealand Institute of Public Administration, p. 3

${ }^{60}$ Fairburn, A. R. D., pp 48-9

${ }^{61}$ Haden, Frank, So the earth didn't move after all, Dominion Sunday Times, 11 March, 1990. (No page number kept with cutting.) 
Undoubtedly the concept of a lifetime career service, with entry by recruitment, ensured promotion, security of tenure during good behaviour, and dutiful submission to political direction ${ }^{62}$ was passé by the mid-1980s, and increasingly out of step with the forces of change sweeping the country. Because the traditional public service undeniably did not encourage the development of market-driven entrepreneurs among its professional civil servants, there was by 1984 , when the Fourth Labour Government came to power, a strong perception that the established culture was not going to be efficacious in the pursuit of efficiency sought by the government. ${ }^{63}$ The Treasury presented the incoming Government with innumerable examples of poor state sector performance, ${ }^{64}$ and argued in its briefing paper Economic Management that: -

the departmental form of organization was not conducive to the efficient production of goods and services for the market. Poor performance in this regard was attributed not to the quality of managers, but to the institutional framework in which they operated. This framework was characterised as being marked by special assistance, and lacking in clear objectives, competition, and performance incentives. ${ }^{65}$

Driven largely by fiscal imperatives ${ }^{66}$ but also ideological persuasion, ${ }^{67}$ the Government,

${ }^{62}$ Roberts, p. 36

${ }^{63}$ Martin, (1988), p. 5.

${ }^{64}$ Britton et al, p. 165

65 ibid, pp 165-6. There are numerous references to the problems in the traditional public service which were causing the Treasury concern. e.g. Deane, in Clark \& Sinclair (eds), pp. 14 -15; Martin, in Holland \& Boston, (eds), p. 125. Deane, Roderick, Reforming the Public Sector, in Walker, Simon, (ed), Rogernomics. Reshaping New Zealand's Economy, pp. 116-117, 126-128, gives a detailed account of the difficulties facing the state service as it was confronted with a new economic management style by government.

${ }^{66}$ Douglas, p. 135

${ }^{67}$ Boston, (1991), p. 1 
encouraged by the Treasury, set in motion a reform programme between 1984-92 which was to revolutionise the public service. ${ }^{68}$ Business models from the private sector became the paradigm for the state services, ${ }^{69}$ with commercialisation a primary target for many government departments. ${ }^{70}$ Policy advice based on the premise of public choice theory and agency theory underpinned the changes, ${ }^{71}$ and resulted in a total shift of emphasis within the state sector. Many Government based businesses were sold, a range of activities previously carried out by the public sector were contracted to private companies, ${ }^{72}$ management policies in the remaining departments were altered to improve accountability and efficiency, and there was a separation of policy and service provision functions within departments. ${ }^{73}$ The State Services Act (1988) made a frontal attack ${ }^{74}$ on the employment features of the public service ensuring that the old "career service"

${ }^{68}$ Both the Labour Government from 1984-90 and the National Government elected in 1990 worked on public sector reform

${ }^{69}$ Martin, (1988), p. 5

70 Britton et al, p. 171. Departments which could supply goods and services of some kind were instructed to introduce a user pays system which was intended to reduce the taxpayers' burden while encouraging the expansion of such activities. Both Ministry of Agriculture and the Department of Scientific and Industrial Research were among those departments directed to focus on clients needs.

${ }^{71}$ Boston, (1991), pp 2-6. Public choice theory aims to minimize the role of the state, limit the discretionary power of politicians, reduce public monopolies to a minimum, curb the functions of government agencies, and maximise liberty (understood in the limited sense of freedom from state coercion.), p. 3. Agency theory is concerned with the idea of a contract between a principal and an agent, in which the agent undertakes to perform various tasks on behalf of the principal, and in exchange the principal agrees to reward the agent in a mutually acceptable way, p. 4

72 James, (1992), p. 229

${ }^{73}$ Britton et al, p. 172

74 Martin, in Holland \& Boston, (eds), p. 126 
was gone for good as it introduced new appointment procedures for heads of government departments, created a senior executive service based on performance and accountability, and began to provide for private sector type industrial relations. ${ }^{75}$

Accompanying the assault on the concept of the career service, was an appraisal of the values of the traditional public service ethic. ${ }^{76}$ Although there had never been a formal "ethic" undergirding the process of government administration, by the late 1940s there were two dimensions to the ethos characterising the way public servants approached their work. There was a professional devotion to the ideal of the public interest, ${ }^{77}$ and a sense of duty to the minister and government of the day. ${ }^{78}$ John Martin, in his essay, Ethos and Ethics, points out that there is an inherent tension ${ }^{79}$ between these two duties: -

Stewardship of the public service is indeed entrusted to the government of the day; that is, a corollary of representative government. 'Service to the public' is a task carried out by public officials within the laws and boundaries set by Ministers. $^{80}$

One assumes that the notions of public interest and service to the community guide not only the public servant, but also the politician, ${ }^{81}$ but when community pressure also

${ }^{75}$ Deane, in Walker (ed), p. 128

${ }^{76}$ Martin, John, Ethos and Ethics, in Boston et al, p. 367

77 ibid

${ }^{78}$ Morel, Mary, Ethics in the Public Service, Service, March/April 1992, p. 10

${ }^{79}$ Martin, in Boston et al, p. 377

80 ibid, p. 378

81 ibid, p. 384 
becomes part of the equation, tension can arise over the administration of such issues as welfare and housing ${ }^{82}$ as civil servants find their personal loyalty to the community and the government in conflict.

The 1988 State Sector Act was initially seen to overtly challenge the traditional service ethic ${ }^{83}$ by equating state sector employment with that in the business sector, and thereby indirectly raising the question as to whether the ethical issues confronting the public servant are the same as those of the worker in the private sector. ${ }^{84}$ There seemed to be a subtle suggestion that the practice of ethics in the business world was less than in the public service, ${ }^{85}$ and that the introduction of a managerial approach in government administration would possibly distort the traditional values of the public service, ${ }^{86}$ and heighten the tension already present. Some of these issues were addressed in a book of essays by John Martin, (commissioned by the State Services Commission), The Public Service and the Public Servant, in which the writer concluded that the traditional ideas of duty to public interest and duty to the government of the day, still provide useful

${ }^{82}$ Morel, p. 10

${ }^{83}$ Martin, in Boston et al, p. 368

84 Polaschek, p. 283, stated in 1958, thirty years before the State Sector Act, that the ethical obligations imposed on the public servant were neither greater nor less than those adhering to his business neighbour, but also recognised that nevertheless there was a notion in New Zealand that the responsibilities and moral obligations of public servants are substantially greater than those of other citizens.

${ }^{85}$ Martin, in Boston et al, p. 369

86 ibid 
guidance in the conduct of daily business. ${ }^{87}$ The issue of maintaining ethical standards within the new framework of the public service was also addressed in a Code of Conduct which was published by the State Services Commission in 1990 . Not only were principles of conduct clearly stated, ${ }^{88}$ but the Code encouraged the pursuit of the ideal which gives the Public Service its greatest strength - a "spirit of service" to the community. ${ }^{89}$

Given the scale of the changes in the public service it is not surprising that such discussion about the dominant ethic for the newly reformed service took place. It was widely recognised that instability and structural changes were likely to erode the loyalty of public servants to the state services, ${ }^{90}$ especially as the disruption to expected career

${ }^{87}$ Martin, John, (1991), Public Service and the Public Servant. Administrative Practice in a Time of Change, pp 18-19. Martin argues (p. 10), that it is the duty of the public servant to remind ministers of the crown of the public interest in regard to such considerations as the law, natural justice, the short and long term good, all relevant interests and acknowledgment of previous commitments. The public servant's role is to offer disinterested advice, and ensure that issues are considered rationally and fairly. But, he points out, for the public servant the working rule is that the 'public interest' is what the Government of the day says it is. (p. 12) In terms of service to the public, Martin observes that while public servants should be responsive to the public, ultimately they are accountable to the Government.(p. 13)

${ }^{88}$ State Services Commission, Public Service Code of Conduct, p. 6, lists the principles of conduct which all public servants are expected to observe as:-

(1) Employees should fulfill their lawful obligations to the Government with professionalism and integrity.

(2) Employees should perform their official duties honestly, faithfully and efficiently, respecting the rights of the public and their colleagues.

(3) Employees should not bring their employer into disrepute through their private activities.

${ }^{89}$ State Services Commission, p. 7

90 Morel, p. 10 
paths became a major concern to existing public servants, and the human cost of the

reforms began to be counted. ${ }^{91}$ The extent of the restructuring cannot be overstated, ${ }^{92}$ with the National Government Minister of State Services, Bill Birch, commenting, just prior to announcing further reforms, that massive changes have already taken place. ${ }^{93}$ The numbers of state servants dropped drastically over the years of reform, from 85,000 in 1985 to 45,000 by $1991,{ }^{94}$ contributing in no small way to the county's unemployment figures, and causing considerable distress among even those who escaped unemployment. ${ }^{95}$ Disaffection among remaining public servants could scarcely have been unexpected given the instability and insecurity of their working environment, which in some instances lasted for several years. ${ }^{96}$ Pious words about public interest, and service to the community, were cold comfort to public servants caught up in constant organisational redesign alongside a national economic restructuring.

Two of the departments affected over a lengthy period were the Ministry of Agriculture and Fisheries (MAF), and the Department of Scientific and Industrial Research (DSIR). ${ }^{97}$

${ }^{91}$ Martin, in Holland \& Boston, (eds), p. 135

92 ibid

93 Birch, Bill, Address to the Southern Regional Senior Public Service Managers, 29 November, 1991, p. 3

${ }^{94}$ Britton, et al, p. 175

95 James, (1990), p. 180

96 ibid

${ }^{97}$ An inquiry into the understanding of a particular group of public servants regarding the concept of the work ethic, and their reaction to the constant changes in their work 
Their fortunes were to become linked in $1992^{98}$ via the scientific research both engaged in, but the route each department took during the years of public service restructuring to arrive at this final juncture, were somewhat disparate. Confronted with many of the same issues regarding a need to increase efficiency and accountability, MAF was to a great extent proactive in the early years of civil service reform, while DSIR on the other hand tended to be reactive. ${ }^{99}$ MAF had already begun to examine its role in the community before the Labour Government launched its public service reforms, recognising as early as the late 1970 s that falling returns to farmers were inevitably going to affect the direction of the Ministry. ${ }^{100}$ The removal of agricultural subsidies in 1984 by the new Labour Government marked the beginning of a conscious effort by the Ministry to change its direction from a largely industry-based advisory body, ${ }^{101}$ to one focused on policy advice based on economic and social research. ${ }^{102}$ The Director General's review in the 1985 MAF Annual Report stated: -

environment, became the basis of a survey I conducted in November 1991 of MAF staff and the DSIR division of Geology and Geophysics (GEO). In light of the fact that an interpretation of the results of this survey is to be the cornerstone of much of what follows in examining the issue of a contemporary work ethic in New Zealand, some awareness of the restructuring of the two departments is necessary. (Details regarding the methodology of the survey, and a copy of the survey itself, can be found in Appendix 2)

${ }_{98}$ Duncan, Ian \& Bollard, Alan, Corporatization and Privatization, p. 166. The research division of MAF, and the DSIR divisions were restructured into Crown Research Institutes 1 July 1992.

99 This is a personal view that I cannot specifically reference. However, the account which follows of the reforms that took place in each department, will hopefully bear out my opinion.

100 Nightingale, Tony, White Collars and Gumboots. A History of the Ministry of Agriculture and Fisheries 1892-1992, p. 239

${ }^{101}$ ibid, p. 238

102 ibid, p. 239 
During recent years the directorate-general has spent a lot of time developing new ways of managing MAF. It had become obvious that traditional administrative systems were no longer able to cope in a rapidly changing environment and had to be replaced by an emphasis on researching the future, identifying the responses MAF should make, setting directions and clear objectives, and concentrating on outputs rather than only attempting to contain inputs. ${ }^{103}$

Management acknowledged that much remains to be done before all people have the commitment and confidence to operate differently, and conceded that the alteration of the traditional beliefs and organisational culture of MAF could not be achieved overnight, ${ }^{104}$ but was confident that new systems were beginning to work. ${ }^{105}$

The Government's announcement in December 1985 of its intention to improve the management of the public sector and review expenditure ${ }^{106}$ resulted in a further extension of MAF's internal revision of its structure. There was some relief expressed that the Ministry had already identified the need for change, the observation being made that the situation being faced now would be exceedingly difficult to meet if this strategic planning and implementation had not taken place. ${ }^{107}$ Nevertheless it was also recognised that there was a degree of uncertainty for staff as more organisational development issues were discussed. ${ }^{108}$

\footnotetext{
${ }^{103}$ MAF Annual Report, 31 March 1985, p. 5

104 ibid, p. 6

105 ibid

${ }^{106}$ Douglas, p. 226

${ }^{107}$ MAF Annual Report, 31 March, 1986, p. 42

108 ibid, p. 43
} 
Staff are now faced with a new and stressful industry environment combined with uncertainties about their own careers.... On the positive side, there are many people in $M A F$ who are enjoying and thriving on a more entrepreneurial situation. ${ }^{109}$

The tension of a newly evolving MAF structure, from a loose partnership of largely independent divisions towards a leaner, more corporate organisation, ${ }^{110}$ was compounded by the government's introduction of the user-pays principle in March 1986. ${ }^{111}$ The market mechanism which had come to dominate the Rogernomics of the Labour Government was introduced into the scientific research and development work of both MAF and DSIR, with government financial assistance being slashed, and scientists left competing for profits. ${ }^{112}$ The Director General of MAF, Malcom Cameron, in a panel discussion on the new public sector environment, responded to the Government's user-pays principle by commenting: -

there is the difficulty of introducing a commercial, user-need dominated culture into an organisation in which discipline cultures predominate. MAF is an organisation which is organised in disciplines; veterinarians, scientists, and the like. They've also worked in an environment where, since the user didn't pay, they've often decided what was good for the client and they didn't really have to get out to find out what the market wanted. ${ }^{113}$

\footnotetext{
109 ibid, p. 42

110 ibid, p. 44

111 Douglas, p. 229
}

112 Collins, Simon, p. 75. This insistence on user-pays, according to Collins, replaced the old spirit of scientific co-operation. Research findings were not even available to other Government departments unless they were prepared to pay for them. Collins points out that this profit making through research and development brings into question the place of the public service ethic of serving the community. (p. 76)

113 Cited in Clark \& Sinclair, (eds), p. 37 
MAF nonetheless, recognised the government was serious in its objectives and that as Cameron put it, things are not going to go away in the fashion that they have in the past. ${ }^{114}$ Accordingly the Ministry responded to the realities of the user-pays policy by restructuring on the basis of businesses instead of the previous disciplines, ${ }^{115}$ and eventually earned Roger Douglas' praise for the way it reacted to the public sector reforms. ${ }^{116}$

The restructuring that took place in MAF over the $1987-9$ period was not without pain. As the Ministry realigned itself to the new challenges, staff levels were forced to drop approximately 1,100 by 1989 , with the middle and senior management reduced by half. ${ }^{117}$ The Annual Reports over this period commended MAF staff for the way they faced up to the hard issues, ${ }^{118}$ and the way they have coped, and continue to cope, with

114 ibid, p. 45, citing Malcom Cameron

115 ibid, p. 37, citing Malcom Cameron. The MAF Annual Report 1987-88 detailed the restructuring of the Ministry into four distinct business groups. These were MAF Tech (research and consultancy services), MAF Qual (Quality Management), MAF Fish (conservation and management of fishery resources), and MAF Corp (policy advice, and provider of management support, financial, legal, computer and information services to the other three businesses.)

116 Douglas, p. 230. Douglas' account of the public service review which began with MAF is a humorous narrative of the meeting between MAF officials, Geoffrey Palmer, the Deputy Prime Minister, and Douglas himself. Despite his cynicism towards the attempts of the MAF officials to swamp the politicians with a mountain of paper detailing the importance of their work to the farming and fishing communities, Douglas is respectful of MAF's response to the determination of the Government to reduce the public sector's expenditure.

117 MAF Annual Report, 31 March, 1989, p. 4

${ }^{118}$ MAF Annual Report 1987-8, p. 5 
the almost continual process of change within $M A F,{ }^{119}$ but the Corporate Plan 1988-9 nevertheless made it plain that staff needed to recognise the traditional culture of the Ministry had been changed for good.

$M A F$ people can no longer expect to keep doing the same job in the same way for all or even a large part of their careers. MAF must be flexible enough to respond to the changing environment. If it is to do this, individuals in MAF must be prepared to find themselves in new groupings and/or learning new skills that enhance MAF's own competitiveness. ${ }^{120}$

The MAF Qual Operating Brief for 1989-90, while acknowledging the pain of the previous years, also made it clear that the changes were permanent.

There is no doubt that everyone within MAF Qual has experienced enormous changes in their work environment over the past year and a half. For all of us there has been pain and confusion as old work associations and operating procedures have changed. All of us have lost old friends and fellow workers through severance resignation. These changes have left many wounds. To deny this reality will prevent healing and progress. It is so important now to help each of us to understand that the changes had to happen and must continue. There is not and never was the option of avoiding pain. There never was the option of turning back. The only choices have been about coping with the massive dislocations to the greatest common good. ${ }^{121}$

By 1989 MAF corporate management was vindicating any criticisms of the changes imposed upon it by the Government reforms, claiming that if the primary sector had to be lean and hungry so did MAF. ${ }^{122}$ The Acting Director General, R. E. W. Elliott, pointed out that the times called for the traditions of a responsive, flexible bureaucracy

119 MAF Annual Report, 31 March, 1989, p. 9

${ }^{120}$ MAF Corporate Plan 1988-9, p. 19

${ }^{121}$ The MAF Qual Perspective: An Operating Brief 1989-90, p. 31

122 MAF Annual Report, 31 March, 1989, p. 3 
to be overturned, ${ }^{123}$ and the mantle of paternalism to be shed. ${ }^{124}$ Instead it was essential that the Ministry's management systems be cost-effective, and its people given freedom from the old occupational groupings that had bound them. ${ }^{125}$ In line with Government economic reforms, the disciplines of the market place had been applied to MAF's operations, and its relationships with Government, industry sectors and private enterprises were conducted in a much more businesslike way. ${ }^{126}$ MAF has become something other than a traditional department of state, ${ }^{127}$ Elliott proclaimed.

The restructuring, however, did not stop, despite the self-congratulations of the Ministry. ${ }^{128}$ A number of uncertainties began to intrude upon the organisation as the country approached another election in 1990, particularly the possibility of a potential restructuring of New Zealand's science activities. ${ }^{129}$ By the end of 1990 the concerns were justified with the announcement that government research activities, which included MAF Technology and part of MAF Fisheries, were to be formed into Crown

123 ibid

${ }^{124}$ MAF Annual Report 1988-1989, p. 2 (There are two versions of the annual report one which was presented to parliament, always dated $31 \mathrm{March}$, and a glossy version aimed at the Ministry's clients. Any annual report dated over a two year period is one of the latter.)

${ }^{125}$ MAF Annual Report, 31 March, 1989

${ }^{126}$ MAF Annual Report 1988-1989, p. 3

127 ibid

128 MAF Annual Report 1990-1991, p. 6. Another internal change took place in 1990 with the establishment of MAF Policy which was to co-ordinate policy advice.

129

ibid 
Research Institutes (CRI's). ${ }^{130}$ A Ministerial Task Group believed that: -

the work of government science has to be refocused to achieve a better uptake in New Zealand and to foster economic growth, understanding of our environment and social development. ${ }^{131}$

The prospect of MAF Tech and Fisheries research facilities being separated from the Ministry in July 1992, meant a considerable amount of additional change within the organisation, and as the Director General, Russ Ballard was to comment in his annual report for 1992, a great deal of energy, time and emotion was devoted to major restructuring of the Ministry during the financial year ${ }^{132}$ The Corporate Contract for 1991-92 had recognised that the substantial degree of change which would occur during that year was going to require a great deal of management attention, particularly if the process is to be minimally disruptive and fair to those affected by the change. ${ }^{133}$ While the move into CRIs was the principal act of restructuring, other changes were also being mooted pertaining to MAF Qual's future, and levels of support staff throughout the organisation were being scrutinised. ${ }^{134}$ Fundamentally, the whole of MAF was affected in some way by the 1991-92 reforms, and Ballard noted in his report for that year that the restructuring had left the Ministry: -

with some residual problems which will require attention to prevent negative impacts......Staff 'grieving' for the old MAF or alienated by the restructuring

130 ibid, p. 7

${ }^{131}$ Major changes to government science proposed, Service, June, 1991, p. 6

${ }^{132}$ MAF Annual Report, July 1991- June 1992, p. 5

${ }^{133}$ MAF Corporate Contract 1991-92, p. 6

134 Another 200 staff were declared surplus as a result of this round of restructuring. (MAF Annual Report July 1991-June 1992, p. 5) 
process will need to be remotivated... ${ }^{135}$

While MAF was left as a smaller, consolidated organisation with more integrated activities by the establishment of the CRIs, DSIR on the other hand was disbanded in its entirety. The following tongue-in-cheek "death" notice appeared in the first newsletter of the Institute of Geological and Nuclear Sciences: -

\section{DEATHS}

RESEARCH, Department of Scientific and Industrial (DSIR) - (torridly, result of historical accidents), in its 67th year, loved father and mother figure of Sadly missed...A service will be held at ...on Friday 3 July, $1992^{136}$

The demise of DSIR may have resulted in an apparent incongruous sense of humour among some of the effect staff, ${ }^{137}$ but the management response to the reforms which occurred prior to the establishment of the CRIs tended to be one of bewildered reservation. Confronted with reductions in funding, user-pays policies and a very different way of doing science, the Department stated in its 1986 Annual Report that: -

Some concern must be expressed that this increasing proportion of external finance may adversely affect the amount of long-term strategic research which

135 ibid, p. 7

136 Institute of Geological and Nuclear Sciences, Newsletter, July, 1992, Vol.1, no. 1, p. 3

137 See Appendix 3 for a "parable" written for the disbandment of DSIR Geology and Geophysics, by a senior manager, Euan Smith. An important point to note in this "parable" is the fact that Smith refers to the work of the scientists as play. This is not simply rhetoric - for many of the geologists their work was their hobby although the survey undertaken in 1991 was not able to reflect this aspect of their attitude towards their work. 
DSIR should undertake in the future national interest. ${ }^{138}$

The Government's insistence that the Department must start to demonstrate a higher degree of efficiency and commercialism resulted in the eventual issue of a corporate plan in $1987,{ }^{139}$ but management initially welcomed with relief the conclusions of a Ministerial Working Party scrutinising science funding in New Zealand, which deemed that any further reductions in funding should be delayed until the full implications were understood. ${ }^{140}$ Any suggested postponement of cutbacks was considered pleasing if it gave the Department time to review its operations, but by 1988 DSIR, albeit reluctantly, had started to face up to the determination of the Government to reform the public sector. In an attempt to fairly allocate what funding it was receiving, a system was introduced within the Department whereby divisions had to compete among themselves for the available Government funds, as well as developing commercial contracts to make up any financial shortfalls. ${ }^{141}$ It was a difficult time for the Department,

because in a time of industry and Government restructuring it was not easy to obtain contracts from other organisations for research and development which require long term planning. ${ }^{142}$

138 DSIR Annual Report, 31 March, 1986, p. 6. This attitude is associated with the traditional public service ethic of serving the good of the community.

139 DSIR Annual Report, 31 March, 1987, p. 5

140 ibid

141 DSIR Annual Report, 31 March 1988, p. 9

142 ibid, p. 12 
Anxiety levels were also raised by the external review which had been ordered by the Government ${ }^{143}$ to advise on the needs and opportunities in New Zealand for different science and technology fields. ${ }^{144}$ The issue of quality and relevance of research, as a result, became part of DSIR's own corporate planning process over the 1988-89 period. Consultation with the Government Minister led to identification of some programmes that were no longer relevant and could be wound down, and a validation of other important and developing areas of scientific research. ${ }^{145}$

If the Department hoped this would deter any further Government interference in science restructuring it was to be disappointed. The Report of the Science and Technology Advisory Committee (STAC), released in October 1988, raised questions about the appropriateness of DSIR as a Government operational scientific organisation, ${ }^{146}$ and recommended the formation of a new Ministry of Science and Technology which would provide policy advice to Government about appropriate public good science and research, ${ }^{147}$ and the establishment of a Foundation for Research, Science and Technology, that would allocate government funding on a competitive basis to all scientific organisations from a Public Good Science Fund. ${ }^{148}$

143 ibid, p. 15. The Science and Technology Advisory Committee had been established in 1987

144 ibid. These reviews also effected MAF.

${ }^{145}$ DSIR Annual Report, 31 March 1989, p. 10

146 ibid, p. 14

147 Galbreath, Ross, DSIR. Making Science Work For New Zealand, p. 253

148 ibid. 
Over the period 1985-89 DSIR management had become increasingly aware of the effects that the funding changes and user-pays policies were having on staff. The Department admitted in its 1989 Annual Report that the changes had created a difficult environment, but claimed that: -

The staff morale was improved with the Government announcement that the new system [ recommended by STAC] would be based on the strengths of the existing organisations such as DSIR rather than through a major restructuring; also that changes to allocation process systems would be gradual. However, residual uncertainties are causing loss of some key staff members from DSIR and New Zealand. ${ }^{149}$

Earlier concerns expressed in 1985/86 Annual Reports however, had been more directed at staff losses due to noncompetitive salaries than towards any apprehension by staff regarding Government reforms of the public service. ${ }^{150}$ It was the changes brought about by the reduction in Government funding and the demand for commercial initiatives that led to the first recognition by management that staff were having to undergo a fundamental shift in mind set. ${ }^{151}$ A naïve belief that new personnel systems would help alleviate staff discontent and assist in adjusting staff to the fundamental changes occurring ${ }^{152}$ was to prove unsound, with a State Services Commission review over the 1988/89 period expressing concern about the morale of some Divisions and staff

149 DSIR Annual Report, 31 March, 1989, p. 17

150 DSIR Annual Report, 31 March, 1985, p. 6; DSIR Annual Report, 31 March, 1986, p. 6

151 DSIR Annual Report, 31 March, 1987, p. 6

152 ibid; also DSIR Annual Report, 31 March, 1989, p. 12 
members in the changing and difficult area of Government science. ${ }^{153}$

Unlike MAF, DSIR had not suffered significant redundancies in the first few years of public service reform, with only one small division being disbanded in the 1986-87 financial year, ${ }^{154}$ and the loss of a relatively small number of staff from the soil research sphere in $1988 / 89 .{ }^{155}$ The structural changes which occurred in 1990 however, amalgamating the 25 divisions into ten, did see staff surpluses, and sent morale plunging to an all time low. ${ }^{156}$ The Chief Executive, Mike Collins, nonetheless, praised the staff for coping well,

with an extended period of uncertainty, and with the additional burdens placed on them by the restructuring and by the additional responsibilities of the new accountancy procedures. ${ }^{157}$

He also commented that a period of stability was required to ensure the realisation of the staffs' full potential, ${ }^{158}$ but the new Government had other ideas. Before DSIR had barely had time to adjust to its new structure, the announcement was made regarding the establishment of the Crown Research Institutes, with the aim of providing the country with science and research structures which had a commercial potential in the market

${ }^{153}$ DSIR Annual Report, 31 March, 1989, p. 14

154 DSIR Annual Report, 31 March 1987, no page number recorded.

155 DSIR Annual Report, 31 March, 1989, no page number recorded.

${ }^{156}$ DSIR Annual Report, 30 June, 1990, p. 45. (Interestingly I have no reference of the Annual Report referring to the staff surpluses.) Galbreath refers to the shedding of significant numbers of scientific and general staff in a series of redundancy rounds before 1992, and again in 1992. (p. 254)

157 ibid, p. 4

158 ibid, p. 5 
environment. $^{159}$

DSIR was to become an historical entity. The same humorist responsible for the DSIR "death" notice, however, produced a "birth" notice illustrating that life in this portion of the reformed public sector at least, was going to continue, albeit in a very different shape: -

\section{BIRTHS}

CROWN RESEARCH. Rangi and Papa are thrilled to announce the arrival into this world of Landy, Watery and Geo, on 1 July, 1992, at ....., bonny triplets. Special thanks to Simon Upton, Board of Chairs, and staff of the disestablishment Units. ${ }^{160}$

Clearly the public sector reforms led to radical change for both MAF and DSIR. As Geoffrey Palmer pointed out in his opening speech at the 1987 Conference of the New Zealand Institute of Public Administration, the process of change was not just in structures and systems, but in people. It has led to changes in the way people are thinking and working, and in what they are striving for. ${ }^{161}$

It was this issue of continual change, its influence on people in the public service, and its possible effect on their work ethic, which led to the survey conducted in November

159 Galbreath, p. 253

160 Institute of Geological and Nuclear Sciences, Newsletter, Vol. 1, no. 1, p. 4. (The "triplets" referred to were the CRIs of Land Environment (Landy), Atmosphere and Water (Watery), and Geological and Nuclear Sciences (Geo) )

161 Von Tunzelmann \& Johnston (eds), citing Palmer, p. 2 
1991 among MAF and DSIR Geology and Geophysics (GEO) staff. Specifically asked about the effects of the changes on their attitudes, the MAF and GEO staff demonstrated significantly differing responses.

(See Table 1 on next page)

TABLE 1: Affects of changes in MAF and DSIR GEO on staff attitudes.

(Percentage results are representative of the total number of responses for this question)

\begin{tabular}{||l|c|c||}
\hline & MAF (\% of responses) & $\begin{array}{c}\text { DSIR GEO (\%of } \\
\text { responses) }\end{array}$ \\
\hline $\begin{array}{l}\text { Level of commitment has } \\
\text { dropped }\end{array}$ & 15 & 25 \\
\hline Work harder and longer & 15 & 12 \\
\hline Change is a challenge & 17 & 9 \\
\hline $\begin{array}{l}\text { The "old" MAF/DSIR } \\
\text { was better }\end{array}$ & 10 & 14 \\
\hline Greater commitment & 5 & 14 \\
\hline $\begin{array}{l}\text { Fed up with change; loss } \\
\text { of enthusiasm }\end{array}$ & 9 & 16 \\
\hline No effect on attitude & 20 & 3 \\
\hline $\begin{array}{l}\text { Work less hard and } \\
\text { shorter hours }\end{array}$ & 2 & \\
\hline
\end{tabular}

The GEO staff clearly had a more negative response to the changes affecting them, with $25 \%$ of the responses indicating that the individual's level of commitment to the organisation had dropped as a result of the continual changes, compared to the $15 \%$ of MAF responses. The idea of change being a challenge was notably more well received by MAF staff than their GEO counterparts, with almost twice as many MAF personnel responding in a favourable way to the challenge involved. On the other hand, GEO staff 
demonstrated a higher degree of loss of enthusiasm due to being fed up with change, and also a similar degree of conviction that the "old" DSIR was better. ${ }^{162}$

A pivotal factor in the way staff responded to change, was length of service. ${ }^{163}$ It was found that those who had worked in their respective organisations over twenty years were the most affected, in both positive and negative considerations, but once again largely dependent on the organisation they worked for.

(See Table 2 on next page)

162 Although I have no concrete evidence, it is my opinion that the difference between the two organisations is due to the way change was managed, both at a structural and a personnel level. MAF's initiation of much of its own restructuring prior to the announcement of the establishment of the CRIs, compared to the largely reactive compliance of DSIR management to Government instigation of reforms, resulted I believe, in MAF staff responding more positively to the changes. MAF management also appears from the Annual Reports to have shown more overt concern for staff reactions to the changes than DSIR.

163 Of the total respondents to the questionnaire $22 \%$ had worked for MAF or DSIR for over twenty years; $19 \%$ for $11-15$ years; $18 \%$ for $1-3$ years; $14 \%$ for $16-20$ years; $12 \%$ for $4-6$ years; $8 \%$ for $7-10$ years; and $5 \%$ for less than one year. ( $1 \%$ of respondents did not give a valid answer.) 
TABLE 2: Effect of length of service on responses to change.

(Percentage results are representative of the total number of responses for this question)

\begin{tabular}{||l|l|c|c||}
\hline & \multicolumn{1}{|c|}{ Organisation } & Years of service & $\%$ of responses \\
\hline No effect on attitude & MAF & $11-15$ & 24 \\
& DSIR GEO & $1-3$ & 22 \\
\hline Change as a challenge & MAF & $20+$ & 26 \\
& DSIR GEO & $1-3$ & 30 \\
\hline Greater commitment & MAF & $20+$ & 46 \\
& DSIR GEO & - & - \\
\hline Level of commitment & MAF & $11-15$ & 30 \\
has dropped & DSIR GEO & $20+$ & 35 \\
\hline Fed up with change; & MAF & $11-15$ & 32 \\
loss of enthusiasm & DSIR GEO & $20+$ & 46 \\
\hline The "old" MAF/DSIR & MAF & $20+$ & 35 \\
was better & DSIR GEO & $20+$ & 53 \\
\hline \hline
\end{tabular}

The responses from those who had worked for over twenty years in DSIR GEO illustrate the difficulty these staff had in adapting to the changes as compared to those who had only worked for the organisation for a short time. In MAF the tendency was for the people who had worked 11-15 years for the organisation to have the most problems coping with change, although a good proportion also responded that the changes had not affected their attitudes. Not surprisingly those with twenty plus years of service in either organisation indicated that the "old" structure had been better.

Two decades before this survey was conducted, Alvin Toffler had observed in his book Future Shock, that the constant change within organisations and professional groups led loyalties previously reserved for the organisation, to be transferred to the actual work 
itself. $^{161}$ A question designed to discover where commitment lay for those in the midst of public service reform, confirmed Toffler's statement.

TABLE 3: Commitment to organisation and job (Percentages indicate the total number of respondents)

\begin{tabular}{||l|c|c||}
\hline & MAF (\% of responses) & $\begin{array}{c}\text { DSIR GEO (\% of } \\
\text { responses) }\end{array}$ \\
\hline $\begin{array}{l}\text { Committed to job and } \\
\text { organisation }\end{array}$ & 26 & 33 \\
\hline $\begin{array}{l}\text { Committed to job rather } \\
\text { than organisation }\end{array}$ & 68 & 36 \\
\hline $\begin{array}{l}\text { Committed to } \\
\text { organisation rather than } \\
\text { job }\end{array}$ & 1 & \\
\hline Committed to neither & 5 & 7 \\
\hline
\end{tabular}

Correlation of commitment against the age of respondents showed that in both MAF and DSIR GEO there were growing commitments to the organisation and job as respondents got older, with percentages increasing with almost every age bracket. A reversal in the pattern was illustrated with a similar correlation concerning the concept of commitment to the job rather than the organisation, showing that the younger the respondent, the more likely they were to put the job before the organisation. In both instances however, it was obvious that DSIR GEO's older staff were more loyal to their organisation than their MAF counterparts. ${ }^{162}$ Years of service also had some bearing

161 Toffler, p. 140

162 In DSIR GEO $67 \%$ of the staff over 56 years of age indicated they were committed to DSIR and their job, compared to only $46 \%$ of their MAF peers. (The remaining $54 \%$ of MAF staff over 56 indicated they were more committed to their job than the 
on commitment, with those who had served twenty plus years showing the most commitment to job and organisation in both MAF and DSIR GEO. ${ }^{163}$ Also significant in assessing differences in commitment was occupational class, with the majority of technical staff ${ }^{164}$ in both MAF and DSIR GEO clearly stating that their commitment was to their jobs not their organisation. ${ }^{165}$ Managers, on the other hand, were far more likely to be committed to both their job and their organisation, with half of both MAF and DSIR GEO managers indicating that the organisation was still a pivotal focus for them.

In light of the political compulsion behind the reforms confronted by MAF and DSIR GEO, and the discussions on the notion of a public service ethic, staff were asked if they believed their respective organisations existed to serve the needs of the sectors of the community they ultimately benefited, or the politicians. Despite the changes they had been subjected to, staff of both organisations strongly indicated that they believed their organisations existed to serve the needs of the community, rather than the politicians.

(See Table 4 on next page)

organisation, while only $22 \%$ of this DSIR age group responded this way.)

${ }^{163}$ In both instances approximately $38 \%$ of respondents with twenty years of service and more, stated they were committed to their job and their organisations. Further results regarding years of service showed vastly disparate outcomes between the two organisations.

164 Defined as scientists, technicians, and vets, for example

${ }^{165} 70 \%$ of MAF technical staff, and $65 \%$ of DSIR technical staff put their job before the organisation. 
TABLE 4: Who does your organisation exist to serve?

(Percentages indicate the total number of respondents.)

\begin{tabular}{||l|c|c||}
\hline \hline & MAF (\% of responses) & $\begin{array}{c}\text { DSIR GEO(\% of } \\
\text { responses) }\end{array}$ \\
\hline $\begin{array}{l}\text { The needs of the } \\
\text { community sector }\end{array}$ & 85 & 91 \\
\hline The politicians & 13 & 5 \\
\hline
\end{tabular}

This response was further tested against the mission statements of both organisations, staff being asked if they believed their specific jobs helped to support the mission statements ${ }^{166}$ which described in essence how each organisation served community sectors. In this instance, differences were marked between MAF and DSIR Geology and Geophysics, with $75 \%$ of the DSIR staff categorically stating that they believed their job directly contributed to bringing about the mission of their division, compared to only $46 \%$ of MAF staff believing they did likewise for MAF. The variation between organisations is likely to be due to MAF's greater number of support staff, and specialised inspection staff, ${ }^{167}$ who felt that their jobs only indirectly contributed to the MAF mission. Interestingly, there was a significant deviation between technical staff from each organisation, with $90 \%$ of the DSIR scientists and technicians indicating their jobs directly contributed to their mission, in contrast to only $53 \%$ of the equivalent staff in MAF. It would appear that despite enforced changes resulting in low morale, and

166 The mission statements can be found on the questionnaire.

${ }^{167}$ Support staff is defined here as management support, and managers. $29 \%$ of the MAF respondents came from this category compared to $23 \%$ in DSIR. The MAF inspection staff made up $21 \%$ of the respondents for MAF and in this question made a marked contribution to the final result, with $38 \%$ indicating that their job only indirectly contributed to MAF's mission. 
their shift in commitment, DSIR GEO staff were generally more convinced of their individual inherent worth to the community they served, than MAF employees.

The primary question to be addressed in light of these results is, how was the work ethic of this particular sample group of state servants influenced by the public sector reforms? As members of a society reeling from changes in its economic and welfare systems, and facing high levels of unemployment in the community, they were also directly affected by the government reforms of their workplaces. Did the preaching of work ethic ideology by political figures in an environment of radical change, in any way touch the values of these specific individuals and alter the way they approached their paid employment? The examination in the next chapter of work ideology in New Zealand during the period under study, and a further analysis of the survey results, can be expected to give some answers. 
PART THREE 


\section{CHAPTER 7}

\section{Restructuring the Understanding of Work}

Restructuring of the New Zealand economy from Keynesian policies to free market practice in reality meant a call for the restructuring of work. ${ }^{1}$ The demand from the political leaders, represented by Ruth Richardson, for a reassessment of work attitudes so that New Zealand could be raised from a hole of dependency and debt to a high growth, high employment economy, ${ }^{2}$ demonstrated a return to a work ethic which had, according to Richardson, all but disappeared with the welfare state. ${ }^{3}$ The quicker we all grasp that life, as we want it, must be based on a strong work ethic, and excellence, the faster it will happen, ${ }^{4}$ Richardson declared.

The question of the existence of a work ethic in the postwar, welfare state years of full employment, was not confined just to Richardson and her colleagues in the National Government of the early 1990 s, however. The observation has already been made that for at least the previous twenty years New Zealanders had been blamed as a people by the politicians, for their own misfortunes, and nagged and berated as cringing supplicants begging from the state, with their work ethic, initiative and independence

${ }^{1}$ Austin, Terry, Work, in Spoonley, Paul; Pearson, David; \& Shirley, Ian, New Zealand Society, p. 241

2 Richardson, Ruth, State of the Nation Speech, 3 April, 1991, p. 1

3 ibid, pp 2, 5; also in Richardson's Address..., 27 March, 1991, p. 3

${ }^{4}$ Richardson, 3 April, 1991, p. 8 
sapped by the previous fifty years of the welfare state. ${ }^{5}$

But not only politicians were critical of the lack of perceived work ethic. Commentators on New Zealand society as early as the 1950 s, for example, were remarking on the inadequacy of the work ideology embraced by many New Zealanders. Bill Pearson in his essay, Fretful Sleepers, suggested that "socialist legislation" was responsible for the inertia of most New Zealanders in regard to their work. ${ }^{6}$ He writes: -

the local inertia is not a fear of work, it is an idea that each of us should do no more work than the next man, and in doubt its better to do a little less than a little more......The ambition is a coveting of other men's riches without the will to work for them, a willingness to get the same by a short cut like the black market or an art union...But even the New Zealander who is turning over money fast is only passing time. The New Zealander's ideal state is a halfconsciousness; his ideal activity is reunion, physically expressed in the old boys reunion or the football dinner...

A study of New Zealand society published by American, David Ausubel, in 1960, included a chapter on work ideology, which was equally disparaging. New Zealanders he observed, believed that, like their pioneer forebears, they were hard working, enterprising, ambitious and provident, ${ }^{8}$ but in comparison to their American counterparts, they were apathetic and devoid of enthusiasm in regards to their paid employment. ${ }^{9}$ He further comments: -

5 McLauchlan, (1992), p. 12

${ }^{6}$ Pearson, Bill, Fretful Sleepers and Other Essays, p. 20

7 ibid

${ }^{8}$ Ausubel, David, P., The Fern and the Tiki, p. 34

9 ibid, p. 35 
(An) unfortunate consequence of the lackadaisical and casual attitude towards work that prevails in New Zealand is a lamentable decline in standards of efficiency and dependability. In far too many places of business one encounters slackness, indifference, and neglect. ${ }^{10}$

Ausubel attributes this modification of pioneer work habits to the welfare state principle, which he describes as an outgrowth of egalitarian ideals that diminish the recognition of occupational achievement. ${ }^{11}$ Because occupational accomplishments and prestige are inconsistently rewarded by the welfare state, he suggests that New Zealanders have difficulties in seeing the purpose of expending effort on their jobs. ${ }^{12}$ Instead they will work like a fiend on their homes, and gardens, or at sports, because the rewards of their labour are instantly recognisable. ${ }^{13}$ However, while the New Zealander's level of ambition and endeavour is extremely high in sports and household labour, Ausubel laments the fact that the standards the New Zealander sets for himself in matters connected with the national economy are neither impressive nor challenging. ${ }^{14}$

Similar sentiments were expressed in the late 1970s by an international business consultant working in New Zealand, W. J. Twinn. Impressed by the hard work and effort put into home improvement over weekends by property owners, he comments: -

${ }^{10}$ ibid, p. 37

${ }^{11}$ ibid, p. 42

${ }^{12}$ ibid, p. 43. Ausubel also suggests that the bureaucratic organisation of the welfare state itself contributes to negative work attitudes. He is highly derogatory of the civil service, commenting that many civil servants do not really earn their pay. According to him a commonly expressed attitude among New Zealanders is If they can get away with it, why should I overexert myself? (p. 44)

${ }^{13}$ ibid

${ }^{14}$ ibid, p. 36 
My amazement at all the technical ingenuity and hard work required is second only to my surprise that these amateur master-builders show absolutely no sign of this originality and application during their week days at work. ${ }^{15}$

New Zealanders, it appeared, did not accept work and the work environment as a significant part of their lives, ${ }^{16}$ but the nation, Twinn implied, was not going to find future prosperity unless the skill and ingenuity of the people was also utilised in their work situation. If people could be motivated to use their abilities and enthusiasm at work in the same way they applied them during their leisure time, then New Zealand could look forward to a successful economic future. ${ }^{17}$ Similarly, the writers of Theory $K$, a much vaunted book in the late 1980 s regarding the pursuit of business excellence, not only decried poor work ethic as a barrier to excellence ${ }^{18}$ but asserted that unless the energy New Zealanders applied to their personal and leisure pursuits was directed towards their employing organisations, most work places would continue to perform well below capacity. ${ }^{19}$

Clearly, by the time the Fourth Labour Government began to introduce free market economic policies in 1984, there was an understanding in some significant spheres of influence that New Zealanders had a poor work ethic. This perception was increasingly coloured over the next few years by rising unemployment figures and the economic mire

15 Twinn, W. J., The Kiwi and the Work Ethic, New Zealand Journal of Industrial Relations, Vol.2(3), November, 1977, p. 98
16 ibid, p. 99
17 ibid, p. 100
${ }^{18}$ Inkson, et $a l$, p. 2, as already quoted in Chapter 1.
19 ibid, p. 5 
that New Zealand found itself struggling to escape from. The work ethic of ordinary

New Zealanders therefore became a convenient scapegoat for politicians struggling to find an excuse for the country's poor economic performance. ${ }^{20}$

The irony is that there is a possibility that a high proportion of the population did not understand what the politicians were accusing them of..$^{21}$ The survey undertaken with MAF and DSIR GEO staff, in November 1991, demonstrated that only $60 \%$ of 432 professional or semi-professional people, had ever heard of the work ethic. Younger people in particular had not heard the expression before, and asked if they thought there was a work ethic in New Zealand, were naturally unsure because they had no understanding of the concept. Individuals aged over 35 were far more likely to have heard of the work ethic, ${ }^{22}$ and to acknowledge the existence of a work ethic in New Zealand, ${ }^{23}$ but nonetheless a considerable percentage of those questioned had never

${ }^{20}$ This is a purely personal viewpoint. I suspect the concern expressed in the USA about their so-called declining work ethic, and Britain's Margaret Thatcher's passion for the work ethic, were adopted by New Zealand politicians as they searched for an explanation or excuse, for the deteriorating economy

${ }^{21}$ Nowhere that I have found, did Richardson ever define what she understood by "work ethic". I assume, (a dangerous thing to do academically), that she was referring to the concept of hard work in particular, but her lack of an explanation as to what she meant by the phrase "work ethic" did not assist those with no knowledge of the philosophy behind it, to grasp her meaning. It is likely that Richardson embraced what Douglas Meeks in his book, God the Economist, has described as a "success ethic," the characteristics of which are discussed in the next chapter.

$2270 \%$ of those over 35 had heard of the work ethic

$2362 \%$ of those aged $36-55$ believed there was a work ethic in New Zealand. The proportion of respondents who were uncertain about the existence of a work ethic basically coincided with the percentage who had indicated that they had not heard of the work ethic. (that is, $38 \%$ unsure compared to the $40 \%$ who had not heard of the work ethic.) There was a significant difference between the responses from MAF and DSIR GEO. $50 \%$ of MAF staff replied that there was a work ethic in NZ compared to $63 \%$ of 
come across the expression before, despite media coverage of political speeches in which Richardson had consistently called for a renewal of the nation's work ethic. ${ }^{24}$ If a considerable proportion of a group of professional, middle class people were not clear about the meaning of "work ethic," one has to wonder what ratio of the general population understood Richardson's message.

Concern about the supposed decline of the work ethic was not confined to New Zealand, however. For example, Margaret Thatcher, former Prime Minister of Great Britain, consistently proclaimed her belief in the virtue of work, ${ }^{25}$ and had a well-advertised attachment to the work ethic. ${ }^{26}$ Anxiety about world recession, inflation and

DSIR GEO personnel; and $42 \%$ of MAF staff were unsure about the existence of a work ethic, compared to $28 \%$ of DSIR GEO respondents. Given that age groupings were very similar in the two organisations, age does not appear to be factor in this variation. The only suggestion I have for the divergence between the two sets of responses is the possibility that occupational grouping may have a bearing. $69 \%$ of DSIR GEO respondents were technical staff as compared to $36 \%$ of MAF workers, which possibly indicates a higher standard of education among DSIR GEO staff, and therefore more awareness of intellectual concepts such as the work ethic. Unfortunately the survey did not include data on educational levels of attainment so this proposition is pure conjecture.

${ }^{24}$ The definitions of "work ethic," given by those who had indicated that they had heard of the concept, however, displayed a high degree of a traditional understanding. By "traditional" I mean a broad understanding of the work ethic as equating to industriousness and perseverance resulting in financial reward, accompanied by a belief that work is for the good of society. ( See Appendix 4.) There was a however, significant $25 \%$ who equated the expression with work place conditions and management practice rather than a personal work ethos. This identification of the work ethic with managerial ethics will be further discussed later in the chapter.

${ }^{26}$ Samuel, Raphael, Mrs Thatcher's Return to Victorian Values, in Smout, T. C., Victorian Values: A Joint Symposium of the Royal Society of Edinburgh and the British Academy, December, 1990, p. 10 
unemployment ${ }^{27}$ led Thatcher to believe that values, such as a positive view of work, that had sustained Britain's national character for generations, were being undermined..$^{28}$ Accordingly, she called for the will and purpose to revive and maintain them, ${ }^{29}$ and it has been observed that when arguing for fiscal reform, the work ethic was Thatcher's favoured idiom. ${ }^{30}$ There is little doubt that she was devoted to what she believed were Victorian values of hard work, self-reliance and thrift, ${ }^{31}$ and that during the mid-1980s she regularly elaborated on the merit of such virtues. ${ }^{32}$

In the United States, where the Puritan work ethic had been judged by Americans to be relatively strong until the $1980 \mathrm{~s},{ }^{33}$ critics were claiming that there was a clear decline in the work ethic that was, instead, being replaced by an emphasis on the self..$^{34}$ The suggestion has been made that the industrialisation of America with its numerous factory assembly lines, led to the gradual erosion of the work ethic. ${ }^{35}$ The connection between effort and reward, a strong component of the American nineteenth century work ethic, was diminished in the factory setting as trade union/management contracts determined

${ }^{27}$ Thatcher, p. 127

${ }^{28}$ ibid, p. 131

${ }^{29}$ ibid

${ }^{30}$ Raphael, p. 13

${ }^{31}$ ibid, pp. 12-13.

${ }^{32}$ ibid, p. 12

${ }^{33}$ Eisenberger, Robert, Blue Monday. The Loss of the Work Ethic in America, p. 24

${ }^{34}$ Bellah, Robert, et al, Habits of the Heart, p. 56

${ }^{35}$ Eisenberger, p. 10 
the level of reward that a worker received. Effort no longer resulted in reward based on achievement. Even white collar workers were granted pay increases and advancement founded on longevity in the company or organisational politics, rather than hard work and perseverance. ${ }^{36}$

By the mid-1980s the claim was made that the foundations of the traditional American work ethic had been eroded away, although respectability and a need for income, meant paid employment was still valued. ${ }^{37}$ Instead, it was maintained, the ethics of leisure, entertainment and sensual pleasure had replaced positive work values. ${ }^{38}$ Not all American writers agreed with this assertion, however, ${ }^{39}$ and one group of researchers stated that from their perspective, work actually continued to be: -

critically important in the self-identity of Americans, closely linked to the demand for self-reliance. The problem is not so much the presence or absence of a "work ethic" as the meaning of work and the way it links, or fails to link, individuals to one another. ${ }^{40}$

This broader issue of the meaning of work itself, had by this time, been the focus for

36 ibid, p. 15

37 ibid, p. 24

38 ibid, p. 30. Daniel Bell in his book, The Cultural Contradictions of Capitalism, stated as early as 1976, that from his perspective American culture by the 1950 s was more concerned with how to spend money and enjoy itself, than it was about how to work and achieve. Nevertheless he pointed out that the language of the Protestant work ethic was still used, despite the actual abandonment of the values that went with it. (pp. 70-1)

39 Yankelovich, Daniel, The Work Ethic is Underemployed, Psychology Today, May, 1982 , p. 5

${ }^{40}$ Bellah, et al, p. 56 
extensive discussion in the community for a number of years. Largely driven by the concerns of growing unemployment, both internationally and in New Zealand, social scientists, psychologists, community workers and the churches had begun to examine the meaning of work for the late twentieth century, and to challenge the relevance of the traditional ideology, ${ }^{41}$ that accompanied work in the western world. ${ }^{42}$ One writer commented: -

It is deeply significant that as we come to the final years of the twentieth century, "work", an apparently fundamental and unambiguous word, has come to lack precision... Whatever the reason, a society which falters when referring to something apparently so basic to human existence is likely to be changing in a fundamental way. ${ }^{43}$

Crucial to any debate over the definition of work, are the prevailing attitudes and value systems of the community. ${ }^{44}$ If one regards work as being a matter of cultural

${ }^{41}$ The concept of the work ethic is part of this wider ideology of work. Julius Gould is cited in Wogaman, J. Philip, Christians and the Great Economic Debate, as defining ideology as a pattern of beliefs and concepts (both factual and normative) which purport to explain complex social phenomena. (p. 10) Wogaman believes an ideology is a complex weaving together of values and beliefs. (ibid)

${ }^{42}$ Initially the discussion began in the United States and Britain in the 1970s with books like Stud Terkel's Working (1972), and P. D. Anthony's The Ideology of Work (1977). In the 1980s a rash of books on work appeared, e.g. Roger Clark's Work in Crisis (1982), Michael Maccoby's Why Work: Leading the New Generation (1988), Daniel Yankelovich's Work and Human Values (1983), John Raines and Donna Day-Lower's Modern Work and Human Meaning (1986), and David Bleakley's Work: The Shadow and the Substance(1983), to name just a few. Theologians such as Paul Ballard, Paul Marshall, Margaret Kane, Jurgen Moltmann, Lee Hardy, and Matthew Fox among many others, joined the list of authors who produced books examining work ideology.

${ }^{43}$ Bleakley, David, (1985), Beyond Work - Free to Be, citing R. E. Pahl, p. 6

${ }^{44}$ Clark, Roger, Work in Crisis, p. xxi 
convention, ${ }^{45}$ or a social construction, ${ }^{46}$ it is clear that any modification of the meaning of work in society therefore points to changes, not only within the realm of work, but also within the society and culture itself. ${ }^{47}$ Commentators such as Daniel Yankelovich and his research colleagues pointed to the postwar years as the beginning of this change in work values as emphasis was placed by a new generation on alternative life values that included: -

creativity, autonomy, rejection of authority, placing self-expression ahead of status, pleasure seeking, the hunger for new experiences, the quest for community, participation in decision making, the desire for adventure, closeness to nature, cultivation of self, and inner growth. ${ }^{48}$

The sixties and seventies generations, it is suggested, began to pursue quality-of-life values that led to a lesser commitment to work while paradoxically being accompanied by a greater demand for rights and rewards within the work place. ${ }^{49}$ This retreat from the importance of work involved a search for self-fulfilment which implied that there was something inherently wrong with working hard toward conventional goals. ${ }^{50}$ Instead, people had an expectation of immediate gratification without the willingness to work for the materialistic pleasures they wanted. ${ }^{51}$ Priorities other than a commitment to

${ }^{45}$ Austin, in Spoonley et al, p. 227

${ }^{46}$ Hill, Roberta, Couchman, Paul, \& Gidlow, Bob, Work and Technology, in Green, Paul D., (ed), Studies in New Zealand Social Problems, p. 214

${ }^{47}$ Rose, p. 22

${ }^{48}$ Yankelovich, Daniel, et al, Work and Human Values: An International Report on Jobs in the Late 1980s and 1990s, p. 7

${ }^{49}$ ibid

${ }^{50}$ Eisenberger, pp. 18-19

${ }^{51}$ ibid, p. 21 
production, and values that emphasised leisure, were eagerly pursued. ${ }^{52}$

Individual striving was also condemned by a new "social ethic" that discouraged personal ambition, ${ }^{53}$ and was to all intents and purposes, a replacement for the work ethic. $^{54}$ This social ethic attempted to rationalise the demands for loyalty and dedication exacted by organisations as an alternative to an individual work ethic. ${ }^{55}$ The new quality-of-life values which included the conviction that the group is the source of creativity, and that the ultimate need of the individual is to belong within a group, ${ }^{56}$ were behind the emergence of this new contemporary ethic.

This change in outlook was an element of the cultural and societal changes sweeping the Western world, changes that were described as discontinuous and not part of a pattern. $^{57}$ Alterations in work-related behaviours indicated that changed values in society inevitably resulted in some interesting and important shifts in work values, although as Charles Handy comments, due to the fact that discontinuous change requires discontinuous upside-down thinking to deal with it, sometimes the thoughts

52 Yankelovich et al, p. 7

53 Rose, p. 13

54 Whyte, William, H., The Organization Man, p. 11

55 ibid

56 ibid, p. 11

57 Handy, Charles, The Age of Unreason, p. 5. Jones, Barry, Sleepers Awake! p. 36, claims "elements relating to the adoption of new technology have no precedence in economic history," and have resulted in this age of discontinuity. 
appear to be absurd at first sight..$^{58}$ The revised work values which ensue from this discontinuous thinking, Michael Rose points out: -

constitute a renegotiation of traditional notions, linked in far from simple ways to long-term socio-economic developments, and are affected by the presence of new cultural models which may be used as a reference point. ${ }^{59}$

Among the socio-economic developments influencing work values, were new international economic imperatives. By the 1980 s many workers were out of step with the requirement of economies which demanded higher productivity while the workers themselves were still seeking to realise new life values. ${ }^{60}$ Economists consistently failed to deal with these changing values, in part because as economists they invariably emphasised the traditional external values, such as self-aggrandizement, efficiency, status,...security,.... competition,...material goods. ${ }^{61}$ But as people reached for autonomy through internalising the new quality-of -life values, new options opened up to them, both in their choice of work, and in their purchases. Material needs began to reflect individuals' own authentic needs in lieu of those values imposed by advertisers, and big business. ${ }^{62}$ As a result, across the western world, the skewed relationship between economics and work became an issue as people began to question whether work was merely a division of labour with an economic, market value, or whether it had
58 ibid
${ }^{59}$ Rose, p. 93
${ }^{60}$ ibid, p. 8
${ }^{61}$ Ferguson, Marilyn, The Aquarian Conspiracy, p. 359
${ }^{62}$ ibid 
a more important cultural significance. The basic economic theory behind work, that people worked to provide goods and services so that they earned money to in turn buy goods and services themselves, was still endorsed by economists, ${ }^{63}$ but the notion that people only worked for survival reasons was described as becoming more and more tenuous. Yankelovich commented: -

For the majority in all countries work no longer means "Adam's curse" - a disagreeable necessity undertaken solely for survival purposes. Work is increasingly a means for acquiring the good things in life and for achieving psycho-social benefits - the intangibles of social identity, independence, selfesteem, creative self-expression, recognition, fulfilment of potentials, and social stimulation. In other words, work has acquired important non-economic meanings over and above its monetary exchange value. ${ }^{64}$

Accompanying the modification to people's attitude to work, and the expectations of the postwar decades, was a rapid advancement in technology that resulted in a change in the work actually being performed. In turn, the impersonal nature of this technology was to result in the cultivation of a highly personal value system ${ }^{65}$ which in itself was to lead to a change in the work environment. This restructuring from an industrial society to a post-industrial, or service/information society, took only twenty years, ${ }^{66}$ compared to the previous shift from an agricultural society to an industrial one. As the increased technology of the postwar decades led to substantial shifts in the numbers in the work force employed in the primary production sector, there was also an equivalent drift of

\footnotetext{
63 Anthony, p. 5

64 Yankelovich et al, p. 13

${ }^{65}$ Naisbett, John, Megatrends, p. 40

66 ibid, p. 18
} 
workers from secondary to tertiary or service industries, ${ }^{67}$ and by the late 1980 s employment in much of the western world was divided into two main categories, either goods producing, or service producing, ${ }^{68}$ with increasingly high proportions of working populations employed in service industries. ${ }^{69}$ The notion of the post-industrial society, described as a concept to identify a change in the social structure, ${ }^{70}$ centred on the interaction, co-operation and reciprocity between people, rather than the previous hierarchical co-ordination of the industrial society. ${ }^{71}$ In this post-industrial society, where the social unit is the community rather than the individual, ${ }^{72}$ the occupational system was being reworked. In an early study on the service industries, Victor Fuchs wrote: -

Employees in many service industries, are closely related to their work and often render a highly personalized service that offers ample scope for the development and exercise of personal skills...The direct confrontation between consumer and worker that occurs frequently in services creates the possibility

67 Hill, et al, in Green, p. 216 discuss the shifts in New Zealand's employment sector. Emery, Fred \& Phillips, Chris, Living at Work, p. 2, comment on the Australian scene comparing it with similar trends in the United States. Michael Rose suggests that the reason for the increase in numbers working in the service sector is the decrease in numbers working in the agricultural sector. (p. 45)

${ }^{68}$ Maccoby, Michael, Why Work: Leading the New Generation, p. 23

69 Maccoby quotes $70 \%$ of Americans in 1988, ibid, p. 23; Eldred-Grigg, (1990), p. 147, 
of a more completely human and satisfying work experience... ${ }^{73}$

As the world of work moved from manufacturing to service occupations, workers looked to satisfying their own individualistic needs for relationship and community, rather than valuing work as an end in itself. ${ }^{74}$ In contrast to the classic notion of a work ethic comprising hard work and self-discipline, the modern work ethic which has emerged, according to one writer, focuses on teamwork.

It celebrates sensitivity to others; it requires such "soft skills" as being a good listener and being co-operative; most of all, teamwork emphasizes team adaptability to circumstances. Teamwork is the work ethic which suits a flexible political economy. ${ }^{75}$

The values of teamwork that individuals were bringing to their jobs, ravaged the traditional management ideology grounded in the belief that the work ethic endorsed a subordinate/superior relationship in the work place. Much established business ideology, according to P. D. Anthony, validated the theory that managers were authorised to influence workers by promoting work through effective control. ${ }^{76}$ Anthony goes on: -

Ideologies of work and ideologies of management are related...Ideologies of management often appear to be subordinate parts...of ideologies of work. Ideologies of management express a particular and necessary requirement to defend or disguise the authority of those in whose interest work is controlled. Ideologies of work on the other hand, are primarily directed at subordinates; their function is to explain the relative position of the subordinate and to

${ }^{73}$ Victor Fuchs cited by Kumar, Krishan, Prophecy and Progress, p. 205

${ }^{74}$ Rose, p. 44, discussing the ideas of Daniel Bell.

75 Sennett, Richard, The Corrosion of Character, p. 99

${ }^{76}$ Anthony, p. 1 
influence his beliefs and his behaviour concerning the activities he is required to perform. An ideology of work is a defence of subordination and it entails an ideology of management upon which it is dependent. ${ }^{77}$

The new values emerging in society, however, not only influenced those who were classed as "subordinate" in the work place, but the managers themselves. The belief that managers regarded their work as central to their lives, and were totally involved in it, began to crumble in the seventies, as it became increasingly obvious that there were also considerable changes in the managerial environment. ${ }^{78}$ As many New Zealand middle

77 ibid, pp. 2-3. It is this type of ideology I suspect that influenced the responses of $25 \%$ of the public servants surveyed who equated the work ethic with management and employment practice.

78 Anthony, pp. 293-295. (In light of Anthony's comments about the belief in the centrality of work to those in management, and the suggestion that this was changing, two questions about the work habits of public service managers were included in the 1991 survey. Up to $60 \%$ of MAF's middle management were made redundant over the years 1987-1992, which put the remaining managers in a vulnerable position, and seemed likely to have effected their work attitudes. (The MAF figure is a conservative estimate given to me by the former National Deployment Manager, Glenn Horrex. Middle management in DSIR GEO was not decimated in the same way as the majority of the middle mangers were senior scientists who were in charge of research programmes.) Asked if managers had a different attitude from their staff towards work, just over half of all respondents indicated that they believed that managers sometimes had a different attitude, with another $28 \%$ replying that managers did have a different attitude. Among managers themselves, $26 \%$ agreed with this, but it is significant that almost $60 \%$ thought they only sometimes had a different attitude. A more telling inquiry about the beliefs of staff regarding the work level of managers, demonstrated that only $18 \%$ of all respondents believed that managers worked harder and more effectively than their staff, while a revealing $34 \%$ of all staff surveyed stated that while they believed managers worked hard, they also thought they wasted more time and energy than their staff. Managers on the other hand were more inclined to think that they worked harder and more effectively than their staff, with $34 \%$ of their number claiming this. Results were not broken into organisational responses as generally there was little difference between the two organisations in regard to these questions. The relevance of the results is probably questionable as the phrase "different attitude" was never defined, and no correlation between the two questions was done to ascertain if "different attitude" possibly paralleled "worked harder and more effectively," but nevertheless I think the responses show that there was a general belief that the managers in the New Zealand public service of the early nineties, still had an attitude towards work that was classed as somehow "different" from that of their subordinates. 
managers found in the 1980 s to their detriment, when the managers of managers applied to their colleagues the assumptions and values they had been taught to implement towards their subordinates, the whole managerial ethos came under threat. ${ }^{79}$ Previous understandings were brought into question as managers were forced to reevaluate the whole basis of their managerial and incentive systems, ${ }^{80}$ which included their own personal accountability and productivity, as well as that of their employees.

Modern management techniques since the late 1980 s have tried to escape from the traditional hierarchical, authoritarian procedures of the past, and tend to stress that workers and management are in reality on the same team, even if that is something of a fallacy in practice. ${ }^{81}$ The concept of management has to a large extent been replaced with that of leadership, good leaders supposedly being able to inspire others with the power and excitement of their vision, and give people a sense of purpose and pride in their work. ${ }^{82}$ New compensation systems dependent on performance measures and team appraisals have also removed the old bureaucratic subordinate/superior aspects of

(Unfortunately there was no correlation done to ascertain how many of the managers had heard of the work ethic which may have shown significant results. I would hazard a guess that as managers tend to be in the older age groups, that the percentage knowing about the work ethic would have been considerable.)

79 ibid, p. 297

80 Yankelovich, p. 79

81 Sennett, p. 113

82 Kantor, Rosabeth Moss, The New Managerial Work, Harvard Business Review, November-December 1989, p. 91 
management, ${ }^{83}$ freeing up employees to give service without being subservient. ${ }^{84}$ The comment has been made that: -

The new rewards are based not on status but on contribution, and they consist not of regular promotion and automatic pay raises but of excitement about mission and a share in the glory and the gains of success...The new loyalty is not to the boss or to the company but to projects that actualize a mission and offer challenge, growth, and credit for results. ${ }^{85}$

The suggestion has been made that the old managerial ideology in reality undermined the work ethic of the workers, who, especially if they were not adequately rewarded for effective effort, tended to work less energetically. ${ }^{86}$ The new relationship values acted out in the work place over the last three decades have heavily influenced the management ethos, and the way it functions. In place of a classical individualistic work ethic, it could be mooted that a "contribution ethic" was acting as a motivator for some workers by the early 1990 s. $^{87}$

Another cultural factor implicated in the recasting of the meaning of work, was the emergence of the feminist movement in the 1970s. The impact of feminism on the study of the sociology of work, for example, forced sociologists to move towards an all

83 ibid

${ }^{84}$ Ferguson, p. 382

85 Candour, p. 92

${ }^{86}$ Yankelovich et al, p.79

${ }^{87}$ Roger Clark discusses this idea of a contribution ethic at some length. (pp 196-198) It will be addressed fully later in the thesis. 
embracing gender free definition of work. ${ }^{88}$ No longer was the paid work of men in the formal economy the only focus for study. ${ }^{89}$ Queries about the relationship between paid and unpaid work materialised in the light of the amount of unpaid work done by women in the community and the home, ${ }^{90}$ and there was a recognition that the concept of work could no longer be simply defined in terms of paid employment. ${ }^{91}$ As a result of the growing appreciation of unpaid work, arguments began to surface about what activity actually constitutes work, and about the necessity of payment for the stated activity ${ }^{92}$ The recognition began to evolve that women ${ }^{93}$ who were not in paid employment were still economically active due to their unwaged work in either the home or the community, or both. ${ }^{94}$

For many women though, unpaid work was seen as a poor substitute for paid employment. ${ }^{95}$ Frequently unseen and unacknowledged, the voluntary contribution

${ }^{88}$ Austin, in Spoonley, pp. 227-8

${ }^{89}$ ibid, p. 227

90 Craig, Wendy, Women, Unpaid Work and the Welfare State in Simpson, Claire, (ed), Women's Studies Association Conference Papers, 1989, pp. 52-53; West-Newman, Catherine, The Persistence of Sexism in Work, in Spoonley, p. 115

${ }^{91}$ Bleakley, (1985), p.7

92 ibid

93 I have specifically named "women" in this statement in light of the discussion about women and work, but this also applies to men who are unemployed but performing unpaid work

${ }_{94}$ Royal Commission on Social Policy, Towards a Fair and Just Society (June 1988), p. 19

${ }^{95}$ Craig, in Simpson, p. 56 
made by women to the community is largely overlooked despite its productiveness. ${ }^{96}$

On the other hand, the women in paid work tend to be clustered in narrow range of occupations, particularly in the service, professional and sales categories. ${ }^{97}$ The Royal Commission on Social Policy, established by the Labour Government in 1986 in order to judge how New Zealand measured up as a fair and just society, ${ }^{98}$ commented: -

In the workforce, women overall are in a position of disadvantage due to the kinds of work they do and the lack of choices and options their work involves.

They are concentrated in low paid jobs with little or no career structure, training or advancement.... Women have always participated in the paid workforce, but this involvement has been limited by their unpaid work responsibilities. The assumption that all women have these responsibilities also works against those who do not. Through their unpaid work of all kinds, women acquire a wide range of valuable skills and experience, but these are not usually recognised in the labour market. On the contrary, women's unwaged work is likely to be seen as a disadvantage and is frequently used as a justification for inequality in paid employment. ${ }^{99}$

A study done in early 1991 on barriers to career development in the Ministry of Agriculture and Fisheries, reinforced the point that, even in an organisation which claimed to committed to equal employment opportunities, women are concentrated in a narrow range of occupations which tend to limit their contribution to MAF and also their remuneration. ${ }^{100}$ Evidence showed that there was a significant pay gap between

96 West-Newman, in Spoonley, p. 115; also, Craig, in Simpson, p. 56

97 West-Newman, in Spoonley, p. 117

98 Royal Commission on Social Policy, Towards a Fair and Just Society, (June, 1988), p. 10

99 ibid, pp. 19-20

${ }^{100}$ MAF, One Organisation: Two Different Worlds, Report 1: Gender, p. 7. The response rate for the MAF organised survey was $59 \%$ of all staff. $67 \%$ of the respondents were male, and 33\% were female. The survey I conducted later in 1991 in MAF resulted in 
men and women which could not be explained by qualifications, length of work experience, type of work, or aspirations. ${ }^{101}$ The conclusion reached was that gender was possibly a major determinant in this difference in pay. ${ }^{102}$

Gender issues, however, were not the only socially sensitive concerns to affect the study of work in New Zealand and internationally. An acknowledgment that each society has its own ideology of work, with different values and meanings pertaining to work and the division of labour, resulted in the recognition that diverse cultures vary considerably in what is meaningful to them regarding work. ${ }^{103}$ A study done by Yankelovich and his colleagues, for example, discovered that Japanese, Israelis, and Americans have a strong work ethic, compared to the British and the Germans who are less enthusiastic about their work. ${ }^{104}$ The Japanese attitude towards work in particular has created interest, given that what is described as the Japanese "work ethic" has been officially promoted by employing organisations to secure moral integration in the firm, and deep personal

a $61 \%$ response rate from the randomly selected $10 \%$ of the total staff. Despite the differences in the size of the groups surveyed, the gender break down of respondents to my survey was almost identical - $65 \%$ males, and $35 \%$ females. In regards to occupational classing my results were in some instances considerably different from the MAF survey. For example $42 \%$ of the female respondents to my survey stated they belonged in the technical class compared to only $33 \%$ in the MAF survey, while only $38 \%$ of the women who responded to my survey belonged in the management support class as compared to $53 \%$ of the MAF survey respondents. (The MAF survey statistics are taken from Table $3: 2$, p. 13 of the report). I can only guess at the reasons for the differences, but wonder if the nature of the survey I undertook appealed to a different range of women.
101 ibid
102 ibid
${ }^{103}$ Rose, p. 25
104 Yankelovich et al, p. 15. 
dependence upon it. ${ }^{105}$ Workers are expected to find a high degree of self-fulfilment in their work, not from financial reward, but from a sense of involvement in a common purpose, and $a$ willingness to adapt to the demands of group-life, and an availability to perform whatever tasks the enterprise community allocates ${ }^{106}$

In New Zealand the cultural differences in respect to work values lie between the predominant Pakeha/ European culture, and the Maori and Pacific Island cultures. The Royal Commission on Social Policy pointed out in its discussion booklet on work: -

In a number of societies work measures the status of people and contributes to a sense of identity. For Maori and Pacific Island peoples however, work is less important than kinship in determining the position of a person in the community. ${ }^{107}$

It may be that this approach to the significance of work is reflected in the numbers of unemployed, with Maori or part-Maori people and Pacific Islanders, far more likely to be unemployed than other ethnic groups. ${ }^{108}$ In part, the unemployment figures can be attributed to a deficiency of skills among a number of Polynesian people, a concentration of Maori and Pacific Islanders in production or labouring positions, ${ }^{109}$ and their possible

${ }^{105}$ Rose, p. 37

106 ibid, p. 38

107 Royal Commission on Social Policy, Work: Its Nature, Role and Value in New Zealand, (1987), p. 4

${ }^{108}$ Royal Commission on Social Policy, (1987), p. 7

109 ibid. The small proportion of Maori or Pacific Island workers in professional, technical, administrative or managerial positions is noted by the Royal Commission on Social Policy, and clearly demonstrated in the MAF/DSIR survey with only $4 \%$ of total respondents indicating that they belonged to these ethnic groups. ( $3.5 \%$ of those who responded were Maori, with a tiny $0.5 \%$ Pacific Islanders.) A further $10 \%$ of the respondents were of other ethnic origins (e.g. Indian, Chinese, or South East Asian, or 
location in geographical regions of high unemployment, but a recognition of the relative unimportance of work to self-identification in these ethnic groups, raises issues which are outside the understanding of the European work ideology and its cultural traditions.

An Auckland study which investigated the work related values of people from five different ethnic backgrounds in 1977, discovered complex differences between the attitudes and behaviour of the various ethnic groups. ${ }^{110}$ Motivation for working, ${ }^{111}$ attitudes to employers and supervisors, ${ }^{112}$ and job performance behaviours ${ }^{113}$ varied between the groups, in some instances to a considerable degree, ${ }^{114}$ demonstrating just how diverse attitudes can be between cultures.

Such questions about the motivation to work, job performance, and ultimately job

German, Dutch, French, North American and British who classified themselves as first generation New Zealand citizens.) Because of the small numbers in ethnic groups other than European New Zealander, very few correlations were done specifically examining ethnic responses to survey questions. As noted in Appendix 2, this means the survey is predominantly based on the answers of European New Zealanders.

${ }^{110}$ Nedd, A. N., \& Marsh, N. R., Attitudes and Behaviour of the Multi-cultural Industrial Workforce in New Zealand, (Working Paper No.1), p. 11. The study involved Pakehas, Maoris, Samoans, Tongans and Cook Islanders.

111 ibid, pp 3-4

112 ibid, pp. 4-7, 9-10

113 ibid, pp. 7-8

114 For example, 29\% of the Pakehas in the study stated that one of their reasons for working was because "it was right to work", compared to $10 \%$ of the Maoris, $9.8 \%$ of the Samoans, $8 \%$ of the Cook Islanders, and $8.2 \%$ of the Tongans. (Table 1, p. 3) In regards to job behaviour $91.8 \%$ of the Tongans responded that they did their present job to the best of their ability in order to get promoted as compared to $74 \%$ of the Samoans, $66 \%$ of the Cook Islanders, $52 \%$ of the Maoris, and $36.2 \%$ of the Pakehas. (Table 6, p. 8) 
satisfaction and the meaning of work, began to be investigated by psychologists in the late $1950 \mathrm{~s}$ and early $60 \mathrm{~s},{ }^{115}$ particularly in the United States. Thousands of articles, dissertations and books on these subjects have been published since then, ${ }^{116}$ and numerous theories suggested. ${ }^{117}$ Most researchers, however, have agreed that for the majority of working people, work is more than just a means to an end, and serves more than merely an economic function. ${ }^{118}$ Attempts to assess findings have resulted in the impression that the meaning people attach to work is important on an individual, organizational, and social level. ${ }^{119}$ One summary of the components contributing to a psychology of work lists the following principal functions of work: -

* Work as a source of identity - the work people do classifies them in terms of class, status and influence, and established hierarchies and groupings from which people derive a sense of security, recognition, belonging, and understanding...

* Work as a source of relationship outside the nuclear family - work allows emotional outlets in family relationships as well as enriching the scope of interpersonal relationships, which in turn has benefits on family life.

* Work as a source of obligatory activity - work provides a very useful framework of regular, purposeful activity....

* Work as an opportunity to develop skills and creativity...

* Work as a factor which structures time - because work structures time into regular, predictable time periods involved with rest, refreshment and actual work, it provides a useful temporal framework within which people can become

115 Landy, Frank J., Psychology of Work Behaviour, pp. 317, 376

116 ibid, p. 397

117 Landy summarises many of these theories in chapters on work motivation and job satisfaction.

118 Furnham, Adrian, The Protestant Work Ethic. The Psychology of Work - Related Beliefs and Behaviours, p. 148

119 ibid, p. 149 
maximally active and happy.

* Work as a sense of purpose - at best work prevents classic signs of alienation such as feelings of powerlessness, self-estrangement, isolation, and meaninglessness while at best, work ensures interdependence with others which helps in the development and achieving of life goals.

* Work is a source of income and control - work means putting oneself in the hands of employers during working hours so long as it provides sufficient money to assure oneself of independence and free choice of leisure and future outside the work-place. ${ }^{120}$

Work thus satisfies physical and security needs, social needs, and individual needs for achievement, ${ }^{121}$ and is deemed to be innate to the quality of life in general. ${ }^{122}$

There is however, a conceptual framework which argues that an individual's motivation to work can either be extrinsic, and focused primarily on the fulfilment of goals and needs unrelated to paid employment, or intrinsic, and directed predominately to satisfying job-related wants and needs. ${ }^{123}$ The values that a person brings to their work are reflected in this hypothesis, and may be values that are either based on the individual's personality, their socio-economic background, or cultural traditions. ${ }^{124}$ It is pivotal to a psychological understanding of the meaning of work, to recognise that the

120 ibid, pp 148-9

121 ibid, p. 173

122 Emery \& Phillips, p. 1

123 Nedd \& Marsh, pp. 2-3. In comparison Landy (p. 369) defines "intrinsic" factors as affecting job satisfaction, and "extrinsic" factors as affecting job dissatisfaction. I have chosen to use Nedd and Marsh's definition as I believe it better describes the New Zealand context in which out of work activities have been said to illustrate a good work ethic in comparison to a so-called poor work ethic in the work place. This implies that many New Zealander's motivation to work is, or has been in the past, extrinsic.

124 ibid, p. 3 
new values which emerged during the 60 s and 70 s challenged traditional attitudes and beliefs, and led to a new outlook on life for many. Themes of leisure, health, the environment, inner growth, the questioning of authority, pluralistic lifestyles, and a more accepting social morality, ${ }^{125}$ contributed to new values emphasising the expressive side of human experience, which in turn were incorporated into the individual's extrinsic or intrinsic incentive to work.

Yankelovich and his colleagues identified five core expressive values which they believed have transformed the work place in America. ${ }^{126}$ These are (a) expressive success, in which the emphasis is on inner growth rather than on external signs of wealth, ${ }^{127}$ and the individual defines success for him/herself, rather than relying on the perceptions of others; (b) living in harmony with nature; ${ }^{128}$ (c) autonomy, in which the basic imperative is to express one's own nature rather than to suppress or subordinate it to others, ${ }^{129}$ (d) hedonism, or pleasure seeking, which expresses an important part of the individual's potential; ${ }^{130}$ and (e) community, which reveals a yearning for stronger and closer bonds of community with others. ${ }^{131}$

125 Yankelovich et al, p. 46

126 ibid, p. 47

127 ibid

128 ibid, p. 48

129 ibid, p. 49

130 ibid, p. 50

131 ibid, p. 51 
While these values have, according to Yankelovich et al, meant a greater emphasis in the work place on creativity, loyalty, entrepreneurship, high standards of quality, and a strong work ethic, ${ }^{132}$ nevertheless, there is frequently a mismatch between workers' values and the rewards provided by the work place. ${ }^{133}$ Presumably this means that intrinsic motivations are not met, resulting in workers' extrinsic needs growing in importance. If the individual's needs are not being met in the work place it can be assumed that fulfilment will be sought elsewhere. ${ }^{134}$

An alternative theory to the notion of intrinsic and extrinsic motivation, and the concept of expressive values, is that the individual's dynamic values are drives, or motivators, which are energized patterns of thinking, wanting, and acting shared by members of a society. ${ }^{135}$ In his book, Why Work: Leading the New Generation, Maccoby categorises these value drives as survival, relatedness, pleasure, information, mastery, play, dignity and meaning, ${ }^{136}$ and claims that work is a way of developing and integrating these values into the personality. ${ }^{137}$ Maccoby claims that much of the work in the late twentieth century, which he describes as technoservice, ${ }^{138}$ requires substantially higher levels of

132 ibid, p. 41

133 ibid, p. 58

${ }^{134}$ Is this the reason for what appears to politicians to be a poor work ethic in the New Zealand work place?

135 Maccoby, p. 53

136 ibid, p. 55

137 ibid, p. 56

138 ibid, p. 21. Technoservice is defined as the use of systematic knowledge and information-communications technology for the benefit of customers and clients. It 
motivation than in the past, and asks people to work more co-operatively, even if it means renouncing short-term personal gain. ${ }^{139}$ These factors, plus psychological precepts such as trust, caring, meaning, self-knowledge, dignity, ${ }^{140}$ lead the way to the development of the individual's potential, and indirectly benefit the work place.

Ultimately the motivation to work is a complex combination of perceptions, aspirations, and environmental interactions. ${ }^{141}$ Cultural traditions, ethnic differences, and individual values all contribute. The historical belief that people work primarily for economic reasons may have been challenged, but surveys illustrate that it is nonetheless a large contributing factor even when taking into account the changed values of the last three decades. The international survey conducted in 1983 by Yankelovich et al, for example, shows that the core motives for working were still at that time sustenance and material success. Working to develop oneself and one's quality of life was a central motive for less than $20 \%$ of the respondents in the US, Israel, Germany, UK, and Japan. ${ }^{142}$

The Nedd and Marsh survey in Auckland in 1977 confirmed that all ethnic groups were more or less homogeneous in discerning work as a means of earning a livelihood to support their family. ${ }^{143}$ As the authors point out, however, the similarity in motivation

follows on from the concept of work in the service sector.

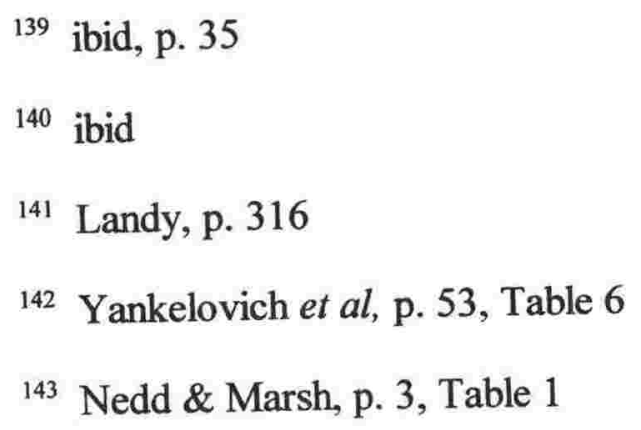


between ethnic groups ends there. A primary reason for working for Pacific Islanders was to either help kinsfolk, or to save to meet some goal away from the job. On the other hand a considerable proportion of Pakehas not only indicated that they felt an obligation to work for social and moral reasons, but also that they saw work as a source of interesting and meaningful activity. ${ }^{144}$ Maori people did not see helping kinsfolk as a motivating reason to work, but did indicate that satisfying away-from-the- job goals was relatively important. ${ }^{145}$

The MAF/DSIR GEO survey indicated that while money was of vital importance in why staff worked, personal fulfilment and satisfaction were slightly more important overall. Self esteem, security and a sense of meaningfulness were also important to staff. Of lesser importance but still significant, were being able to make a worthwhile contribution to society, and helping other people. Companionship was moderately important, as was working for the good of the country. ${ }^{146}$ Concerns about the expectations of other people regarding work, and the promotion of leadership were judged as being of little importance.

144 ibid, pp. 3-4

145 ibid

${ }^{146}$ Almost $60 \%$ of the total staff of MAF and DSIR GEO indicated that working for the good of the country was of real or overwhelming importance to them Broken down into organisational responses, there was a slight difference between the two groups, with $58.2 \%$ of MAF staff, and $62.7 \%$ of DSIR GEO staff stating this was a reason of some importance to why they worked. In light of the conclusion of The MAF Way, the Ministry's code of conduct published in October 1990, it might have been expected that the results would have been reversed. The conclusion reads:- "MAF's work is important for the future of the country. We all are, and should be, working for something beyond simply earning a living. When you do your work well, you can contribute to New Zealand's national welfare for years to come." (p. 10) I personally find this quite a remarkable statement about work expectations from MAF management. 
Table 5: Levels of importance in reasons for working.

( Total percentages for all respondents)

\begin{tabular}{||c|c|c|c||}
\hline & Little importance & Real importance & $\begin{array}{c}\text { Overwhelming } \\
\text { importance }\end{array}$ \\
\hline Money & 6.5 & 80.4 & 13.1 \\
\hline Security & 11.3 & 68.2 & 20.5 \\
\hline Personal fulfilment & 6.4 & 63.3 & 30.3 \\
\hline Self-esteem & 10.7 & 65.9 & 23.4 \\
\hline Satisfaction & 4.0 & 66.0 & 30.0 \\
\hline $\begin{array}{c}\text { Other people's } \\
\text { expectations }\end{array}$ & 59.9 & 37.7 & 2.4 \\
\hline $\begin{array}{c}\text { Sense of } \\
\text { meaningfulness }\end{array}$ & 17.4 & 65.6 & 6.2 \\
\hline Companionship & 37.5 & 56.3 & 3.8 \\
\hline Promoting leadership & 65.2 & 31.0 & 7.0 \\
\hline Good of the country & 40.5 & 52.5 & 11.0 \\
\hline Helping other people & 22.3 & 66.7 & 13.7 \\
\hline $\begin{array}{c}\text { Being able to make a } \\
\text { worthwhile } \\
\text { contribution to society }\end{array}$ & 21.6 & 64.7 & \\
\hline
\end{tabular}

There were three relatively significant differences in responses between MAF and DSIR

GEO staff.

Table 6: Organisational differences in levels of importance for three reasons for working. (Percentages are an amalgamation of responses indicating real and overwhelming importance)

\begin{tabular}{||c|c|c||}
\hline & MAF & DSIR GEO \\
\hline Money & 95.1 & 85.9 \\
\hline Personal fulfilment & 92.0 & 97.5 \\
\hline Satisfaction & 95.0 & 100.0 \\
\hline
\end{tabular}


The overall results showed that personal fulfilment and satisfaction were far more likely to be of overwhelming importance than any other reasons for working, and it appears from this further summary of results that it was the DSIR staff who boosted the final outcome. $^{147}$

From Alison Gray's study on The Jones Men, it appears that middle class and upper middle class or professional New Zealand males are more likely to verbalise the importance of job satisfaction and personal fulfilment in respect to their work, than their working class counterparts. Gray comments that the majority of the middle class Jones men expected to get rewards from their work that had nothing to do with pay, ${ }^{148}$ as compared to the working class group who worked for the money, not the satisfaction. ${ }^{149}$

A series of interviews about work in New Zealand complied by McClennan and Gilbertson tends to re-enforce this impression. Interviewees labelled as labourer, ${ }^{150}$

147 A further question examining the characteristics people would look for if choosing a new job provided a different aspect on the reasons for working, by exploring what characteristics were important to respondents. Interestingly results were fairly evenly spread although adequate remuneration headed the list supporting the view that money is still an important aspect of why people work. (Note however, that making a lot of money was at the bottom of the list). In order of importance the characteristics people would look for if choosing a new job were adequate remuneration ( $14 \%$ of responses); the chance to be creative, being helpful to others, working with ideas, and problem solving (each rating $12 \%$ of responses); freedom from close supervision (11\%); providing leadership, and working with people not things (7\%); avoiding high pressure (6\%); and making a lot of money (a lowly $5 \%$ of the responses)

148 Gray, Alison, The Jones Men, p. 111

149 ibid, p. 104

${ }^{150}$ McClennan, Ray, \& Gilbertson, David, Work in New Zealand, p. 8 
freezing worker, ${ }^{151}$ bus driver, ${ }^{152}$ and storeman, ${ }^{153}$ for example, all comment in one way or another, that they are either not particularly satisfied with their work, or extremely unsatisfied, but that it provides a needed income. Those more likely to be identified as middle class or professional people, for instance a doctor, ${ }^{154}$ a policeman, ${ }^{155}$ an ambulance driver, ${ }^{156}$ a lawyer, ${ }^{157}$ or a school teacher, ${ }^{158}$ consistently mention satisfaction and personal fulfilment in their interviews, rather than money. In light of this evidence, the results from MAF and DSIR GEO are hardly surprising in as much as up to $93 \%$ of the staff can be described as middle class and/or professional. ${ }^{159}$ It was therefore highly probable that job satisfaction and personal fulfilment were more likely to be motivators than simply working for economic reasons.

Nevertheless, money was a tangible reason for working among MAF and DSIR GEO

151 ibid, p. 27

152 ibid, p. 237

${ }^{153}$ ibid, p. 277

154 ibid, p. 55

155 ibid, p. 59

156 ibid, p. 80

157 ibid, p. 156

158 ibid, p. 181

$1593 \%$ of the staff described themselves as "general support staff" which was defined in the questionnaire as possibly "drivers, hotel staff". A further $4 \%$ described themselves as belonging to occupational classes not identified in the questionnaire. Because those responding to these groups did not actually define their positions it is difficult to ascertain whether they could be described as middle or working class, but for the sake of this footnote it is likely that a proportion of this $7 \%$ were farm labourers on MAF research farms, gardeners at research facilities, or cleaners. 
staff. Table 7 shows however, that the need for money for survival reasons only, was equalled by the need for money to be able to achieve the things which were important in the life of the respondents, and which presumably provided satisfaction and personal fulfilment outside the work place. The notion of personal security based on a firm financial base was also evidently relatively important. ${ }^{160}$ A lesser number indicated the importance of money to pursue out of work interests, which, remembering that $81 \%$ of the survey respondents were European New Zealanders, is probably in keeping with the Nedd and Marsh survey results which showed that Pakehas were less likely to work to obtain money for away from the job goals than other ethnic groups. ${ }^{161}$

Table 7: The reasons why money is of real or overwhelming importance as a reason for working.

(Respondents were able to indicate more than one reason, therefore percentages are based on the total number of responses.)

\begin{tabular}{||c|c||}
\hline & Percentage of total responses \\
\hline Survival & 24 \\
\hline Personal security & 22 \\
\hline To pursue interests outside of paid work & 18 \\
\hline To obtain material possessions & 12 \\
\hline $\begin{array}{c}\text { To achieve the things that are important } \\
\text { to you in life }\end{array}$ & 24 \\
\hline
\end{tabular}

Despite the alternative psychological explanations determined as being behind human

160 The question can be asked whether this need for money for personal security is a psychological requirement, or whether it is in part based on the traditional work ethic concept of thrift and the delaying of gratification.

161 Nedd \& Marsh, Table 1, p. 3. 
reasons for working, the issue of the importance of money as a motivation to work is still basic to trying to ascertain the existence of a work ethic. The politicians and business people who call for a stronger work ethic usually appear to assume that work is regarded by most people as a practical necessity, or a purely financial transaction, ${ }^{162}$ inferring that people would not work if they did not have to. This tendency for governments and businesses to behave as if this was so, ignores the evidence that other values and motivations are instrumental in why individuals work. ${ }^{163}$

A question formulated by Yankelovich et al to measure the strength of the individual's work ethic in terms of financial reward ${ }^{164}$ was adapted for the MAF/DSIR GEO survey. The results were startling.

Table 8: Work level vs. pay

(Percentages are given for the total number of all respondents.)

\begin{tabular}{||l|c|}
\hline & Percentage results \\
\hline $\begin{array}{l}\text { A) I need to do the best I can in my job, } \\
\text { regardless of the pay }\end{array}$ & 91 \\
\hline $\begin{array}{l}\text { B) The more I get paid in my job, the } \\
\text { more I do; the less I get paid, the less I } \\
\text { do. }\end{array}$ & 7 \\
\hline $\begin{array}{l}\text { C) Working for a living is unpleasant } \\
\text { and I only do what I have to, to get } \\
\text { paid. }\end{array}$ & 2 \\
\hline
\end{tabular}

162 Yankelovich et al, p. 64

163 ibid

164 ibid, pp 64-5. Yankelovich et al stress that they define work ethic in terms of an inner need to work well and hard." (p. 65) 
According to the way Yankelovich et al interpreted their results for a very similar question, the high percentage returning with Response $\mathrm{A}$ indicates a strong work ethic among MAF and DSIR GEO staff. Both Response B, which indicates that work is seen as a financial or business transaction, and Response C, which signifies that work is seen as an unavoidable necessity, reveal a weak work ethic. ${ }^{165}$

Age did not appear to influence the response to this question, although surprisingly the under 25 's scored a $96 \%$ reaction to Response A. They may not have understood the expression "'work ethic" but they certainly appeared to have demonstrated its existence as a component in their work values. ${ }^{166}$ There was difference between gender reactions to this question, with $97 \%$ of the females indicating a strong work ethic compared to $89 \%$ of the males, while a relatively meaningful $9 \%$ of the males saw their work as a financial transaction. It seems possible that because women for so many generations have frequently worked to their ultimate capacity in unpaid positions, that they have carried into the paid work force a previously unheeded strong work ethic that is not based on economics, whereas males have traditionally worked for survival reasons to support their family, rather than because of any inner need to work hard and well.

Putting economic, or survival motivations for work aside altogether, MAF and DSIR GEO staff were questioned directly about their attitude to hard work, a value understood to underlie the traditional work ethic. Response B was adapted from

165 ibid, p. 65

166 It needs to be noted that only $6 \%$ of those responding to the survey fell into this under 25 age group. 
Yankelovich's study and measured a moderate work ethic. ${ }^{167}$

Table 9: Hard work

(Percentages are based on the total number of all responses)

\begin{tabular}{|c|c|}
\hline & Percentage of responses \\
\hline $\begin{array}{l}\text { A) Hard work is a good thing in itself } \\
\text { and I enjoy it }\end{array}$ & 56 \\
\hline $\begin{array}{l}\text { B) Hard work is OK but I don't let it } \\
\text { interfere with the rest of my life }\end{array}$ & 41 \\
\hline $\begin{array}{l}\text { C) Hard work should be avoided if } \\
\text { possible }\end{array}$ & 1 \\
\hline
\end{tabular}

It is interesting that removing the mention of money from the possible reactions of staff to the question alters the ratio of those exhibiting what might be regarded as a strong work ethic. Age only made a small difference to the responses, although the 26-35 age group certainly tended to show a lower rate of response to the idea of hard work being a good thing, than the other groups. ${ }^{168}$

When a comparison was done to investigate whether having heard of the work ethic possibly affected individuals' reactions to concepts about hard work, and their attitude towards their work level and pay, $96 \%$ of those who had heard of the work ethic believed hard work was a good thing and claimed that they needed to do their best at their job regardless of pay. However, $88 \%$ of those who had not heard of the work

167 Yankelovich, p. 65

168 Only $47 \%$ of the respondents aged between $26-35$ indicated that they thought hard work was good thing in itself compared to $58 \%$ of those under 25 , and $60 \%$ of those 35 and upwards. 
ethic also belonged in these categories. From this one can deduce that knowing about the work ethic as a concept does not necessarily attribute to an individual's work ethic. Presumably the standards of a society and its dominant work ideology are instrumental in influencing the reactions of its members even if subconsciously.

The observation has been made that while the evidence collected in many research projects suggests that most people find their work important and derive satisfaction from it, there is a reluctance for people to admit that one's work is boring or disliked. It is pointed out that: -

when there's a general assumption shared by questioner and questioned that one's value is determined by one's work; to admit to hating one's job is to admit to hating one's life. ${ }^{169}$

On the basis of this assertion MAF and DSIR GEO staff were asked to indicate their feelings about their jobs.

(See Table 10 over page)

169 Anthony, p. 274 
Table 10: How do you feel about your job?

(Percentages are given for each organisation, and for all responses)

\begin{tabular}{||c|c|c|c||}
\hline & MAF & DSIR GEO & Total responses \\
\hline I love my job & 6 & 9 & 7 \\
\hline $\begin{array}{c}\text { I am enthusiastic } \\
\text { about it }\end{array}$ & 19 & 26 & 21 \\
\hline I like it very much & 24 & 27 & 24 \\
\hline $\begin{array}{c}\text { On the whole I like } \\
\text { it }\end{array}$ & 41 & 30 & 38 \\
\hline $\begin{array}{c}\text { It doesn't "get" me } \\
\text { one way or } \\
\text { another }\end{array}$ & 8 & 3 & 7 \\
\hline I don't like/hate it & 2 & 1 & 2 \\
\hline
\end{tabular}

From the results it appears that Anthony's observation could be correct, and a further question asking staff whether they enjoyed working for their respective organisations was inclined to verify the above statistics. The impression is that DSIR GEO staff were more enthusiastic about their jobs than their MAF counterparts.

Work as an outlet for personal fulfilment and satisfaction, rather than work for just financial survival, may be the result of the change in values over the last three decades, but there are still indications that remnants of the classical work ethic influence the way people work. What has been called the long hour work ethic, ${ }^{170}$ is one example of the pervasiveness of an ideology that encourages people to work hard and put in long

170 Gibson, Leanne, Rennie Fritchie. Miss Marple of management, Management, August, 1989, p. 26 
hours. ${ }^{171}$ Although the official working week in most western countries is forty hours, and has been for many years, studies in Britain as far back as the early 1970s showed that it was not uncommon for some managers and other professionals to work up to seventy hours a week. ${ }^{172}$ In the United States during the 70 s the big corporations put increasing pressure on staff to keep their businesses competitive, and encouraged them to work ever harder and longer. ${ }^{173}$ Forty hour weeks for top executives became a thing of the past as many watched their colleagues made redundant through corporate takeovers, and worked even harder to try and ensure the security of their own job. ${ }^{174}$ By 1989 a study in the US revealed that the typical professional was working 52.2 hours per week and that many people's working week was at least $15 \%$ longer than it had been in the mid-70s. ${ }^{175}$

In New Zealand, where the forty hour week had been an icon for workers from colonial days, the 1991 census revealed that half of all employed people in New Zealand worked 43 hours or more, with one third of employed men working 50 hours or more. All told, $23 \%$ of New Zealanders in paid employment worked 50 hours or more. ${ }^{176}$

${ }_{171}$ Killinger, Barbara, Workaholics. The Respectable Addicts, p. 14

${ }^{172}$ Kumar, p. 283, citing a study by J. M. \& R. E. Pahl

${ }^{173}$ Killinger, p. 16

174 ibid

175 Harris, T. George \& Trotter, Robert J., Work Smarter, Not Harder, Psychology Today, March, 1989, p. 33

176 Statistics New Zealand, Population Overview, 1991 New Zealand Census, pp. 42-43. The 1996 census, although it asked a slightly different question from the 1991 census, showed that $36.2 \%$ of all employed people were working 45 hours or more, which was slightly higher than the $32.7 \%$ in the 1991 census. The average working week by 1996 
It was recognised in the early 1970 s that many of the people who responded to the drive to work harder and longer became workaholics. ${ }^{177}$ Work to all intents and purposes became their intoxicant, ${ }^{178}$ but it was well into the 1980 s before it was recognised that this sort of obsessive, addictive way of working was actually counterproductive to business and industry. ${ }^{179}$ In fact the first person to use the phrase "workaholic," Wayne Oates, claimed that in the United States of the 70 s, the workaholic's way of life was considered to be (a) a religious virtue, (b) a form of patriotism, (c) the way to win friends and influence people, and (d) the way to be healthy, wealthy, and wise. ${ }^{180}$ The culture, in other words, supported and promoted workaholism. ${ }^{181}$

It has to be stressed however, that the person who works long hours, or simply enjoys working hard, is not necessarily a workaholic. ${ }^{182}$ In New Zealand the intensification of work and the long hour work ethic were principally consequences of economic

for males was 43 hours. (Employment and Unemployment, 1996 New Zealand Census, p. 15). The long hours work ethic has obviously not decreased since the earlier figures were taken.

17 A workaholic is defined as someone who is addicted to the process of work and uses it as a fix in order to get ahead, be successful, avoid feeling, and ultimately avoid living. Schaef, Anne Wilson, \& Fussel, Diane, The Addictive Organization, p. 130

178 ibid

179 Killinger, p. 17

180 Oates, Wayne, Confessions of a Workaholic, p. . 12

${ }^{181}$ Schaef \& Fussel , p. 130

${ }^{182}$ Killinger, pp. 5-6 
restructuring and the Employment Contacts Act. ${ }^{183}$ Threats of job loss hooked many workers into working lengthy hours. ${ }^{184}$ Nonetheless, there was a growing tendency by the late 1980 s for people to justify their existence in terms of their workloads. One newspaper columnist commented, People now boast about being overworked in the same way they used to boast about getting drunk. ${ }^{185}$

Undoubtedly New Zealand had its share of workaholics who used the economic restructuring, the call of the National Government for an increased work ethic, and the high rate of unemployment, as excuses for their compulsive need to work long hours so as to gain the accolades that hard work receives. Unrealistic desires to achieve success and recognition also ensnared other New Zealanders into workaholic behaviours. One advertising agency account manager, for instance, who was working up to seventy hours a week, declared in an interview that I work hard because it's there to do, because I can, because I want to stand out. I want to achieve, not fritter my life away. ${ }^{186} \mathrm{~A}$ journalist, interviewed for the same article, admitted that he had always been a workaholic, working seventy to ninety hours a week at times. He attributed his workaholism directly to his work ethic, and acknowledged he had passed this philosophy on to his sons. ${ }^{187}$

183 Second New Zealand Sweating Commission, Across the Counter: The Lives of the Working Poor in new Zealand 1990, p. 13; Dannin, Ellen J., Working Free. The Origins and Impact of New Zealand's Employment Contract Act, p. 243

${ }^{184}$ Dannin, p. 108

${ }^{185}$ Edwards, Brian, Intemperate Outbursts, p. 165

186 Tocker, Alison, Workaholics, Listener, April 16, 1994, p. 33

187 ibid, p. 35 
If two book reviews cited in the Listener \& TV Times in 1991 are any indication, it would also appear that some of New Zealand's best known entrepreneurs were quite possibly workaholics, setting an example that was abhorrent to some New Zealander's, but a role model for others. Ron Brierly, for example, was said to regard a wife and family as a muisance. They demand time, effort and commitment and prevent him giving himself wholeheartedly to his work. ${ }^{188}$ Likewise, Michael Fay was reported to have stated that he was not interested in workers who put family first. ${ }^{189}$ It is recognised that workaholics become so obsessed and dominated with their work that they lose the ability to be intimate with even their families, as their perspective on the true meaning and value of life and love becomes distorted. ${ }^{190}$ One cannot help but wonder about Brierly and Fay.

An increasing awareness of the hazards of the long hour work ethic and the workaholism that sometimes (but not always) accompanies it, and the pressures of the restructuring in the public service, led to MAF and DSIR GEO staff who responded to the 1991 survey, being asked to reflect on the hours that they were working and why. $46 \%$ acknowledged that they worked between eight and twelve hours a day. ${ }^{191}$ The greatest

188 Giddens Rodney, Viewpoint, Listener \& TV Times, March 25, 1991, p. 7, citing a book review from the Examiner.

189 ibid

190 Killinger, p. 6

191 In both organisations the technical staff were working the longest hours. In MAF of those working $8-12$ hours, $36 \%$ were technical staff, $17 \%$ were inspectors (e.g. fisheries inspectors, agricultural quarantine inspectors, and meat inspectors), $16 \%$ were managers, $13 \%$ were management support staff, $9 \%$ were consultants, $6 \%$ were from unspecified occupational classes, and $1 \%$ were general support staff. In DSIR GEO, $71 \%$ of those working 8-12 hours were technical staff, $13 \%$ were managers, $9 \%$ were management 
proportion of these staff responded that they worked 8-12 hours because they liked to get the job finished (19\%), while another $14 \%$ indicated that they because they liked their work, they did not mind staying. Others working over eight hours, answered that they liked working at their own pace (13\%), or acknowledged that if they did not work long hours they would get more and more behind. (10\%). Only insignificant numbers of staff recognized having a compulsion to work long hours (3\%), or admitted to working long hours out of fear of losing their job(2\%). ${ }^{192}$

It is significant that approximately $75 \%$ of those working $8-12$ hours admitted they would have preferred not to be working long hours. $44 \%$ of these conceded that they would have preferred less pressured lives and believed it would be better for them and the organisation if this was the case. A further $11 \%$ indicated that they would have liked it to be different, but another $22 \%$ claimed they accepted they had no option but to work the long hours even if they did not like it. ${ }^{193}$

support staff, and consultants and general support staff accounted for $4 \%$.

192 There were very few differences between MAF and DSIR GEO responses as to why staff worked 8-12 hours. My personal observation at the time would probably confirm the small numbers admitting to what could be described as workaholism, but the comment needs to be made that those obviously working compulsively tended to be senior or middle managers. Anecdotal evidence would argue that the numbers working long hours for fear of losing their jobs should have been higher than the minuscule $2 \%$ who acknowledged their fear in this part of the survey. Managers from the National Deployment Unit in MAF, who were working closely with redundant staff, commented that those facing redundancy frequently began to work excessive hours as if that was going to somehow halt the process of redundancy. As will be discussed shortly, statistics from another question in the survey indicated that $17 \%$ were prepared to reply that they worked harder to keep their job in the face of unemployment figures. Although this does not mean they worked longer hours I would suggest it is a more honest response.

${ }^{193}$ Only $1 \%$ responded that they got really fed up with working the long hours. There was another $13 \%$ who gave unspecified reasons for preferring not to work 8-12 hours. In MAF the occupational groupings of those who would have preferred not be working 
Despite the indication from MAF and DSIR GEO staff that a fear of unemployment was not a reason for their working 8-12 hours a week, the evidence from community observers would argue that: -

At a time of diminished job opportunities the poison of fear spreads out to infect those who are as yet still in jobs but who in uncertain economic times feel themselves to be at risk. ${ }^{194}$

Restructuring of an organisation during a time of high societal anxiety levels about unemployment is bound to lead to suspicion among staff and add to their fearfulness about their own job security. ${ }^{195}$ Asked bluntly if they were aware of being fearful of possible unemployment, ${ }^{196}$ almost half the respondents admitted they were scared of becoming unemployed. ${ }^{197}$

long hours, appeared to make a difference to the way staff responded. For example $66 \%$ of the managers who worked 8-12 hours indicated they would prefer a less pressured life, $46 \%$ of the management support group, $30 \%$ of the technical staff and the inspectors, and $27 \%$ of the consultants. However, $41 \%$ of the inspectors responded that they had no option but to work long hours even if they did not like it, compared to $27 \%$ of the technical staff and consultants, $23 \%$ of the management support staff, and $17 \%$ of the managers. Of the DSIR GEO staff $67 \%$ of the technical staff answered that they would prefer less pressure, while $22 \%$ of the remaining technical staff accepted that they had no option but to work long hours.

194 Clarke, p. 68

195 ibid

196 It must be remembered that both MAF and DSIR GEO were in the midst of being restructured and staff were fully aware that redundancies were a given. DSIR GEO had already had been through one downsizing, and had just had a second round of redundancies in preparation for the formation into CRI's. MAF's gradual downsizing had been in progress for four years by the time the survey was conducted, with the threat of further redundancies as a result of the establishment of CRIs.

197 The fact that the remaining staff were either not afraid, were unsure how they felt, or had not given the issue of unemployment any serious consideration, may reflect the social make up of the sample group. As Eldred-Grigg, (1990), points out: - Lack of work punished some more than others. Jobless queues were filled almost entirely with people from the working class. Middle class people, though increasingly at risk of losing their 
Table 11: Fear of unemployment

\begin{tabular}{||c|c|c|c||}
\hline & MAF & DSIR GEO & $\begin{array}{c}\text { Total percentage } \\
\text { of responses }\end{array}$ \\
\hline $\begin{array}{c}\text { I am afraid of } \\
\text { becoming unemployed }\end{array}$ & 44 & 52 & 46 \\
\hline $\begin{array}{c}\text { I am not afraid of } \\
\text { becoming unemployed }\end{array}$ & 20 & 17 & 19 \\
\hline $\begin{array}{c}\text { I have not seriously } \\
\text { considered the } \\
\text { possibility of } \\
\text { unemployment }\end{array}$ & 24 & 16 & 13 \\
\hline $\begin{array}{c}\text { I'm not sure how I feel } \\
\text { about it }\end{array}$ & 12 & 14 & 22 \\
\hline
\end{tabular}

Older staff (over 35) were more likely to be afraid of unemployment, while younger staff (under 25) were more prone to have not given the issue any serious consideration. Those over 46 tended to be the group who acknowledged that they were not sure how they felt about the possibility of unemployment. ${ }^{198}$ Technical staff, managers and management support staff, and inspectors were those most apt to express fear of unemployment. $^{199}$

A further exploration of the effect of unemployment figures ${ }^{200}$ on people's attitudes to

job for a time, usually found new work quickly at a good salary. ( p.173)

$19850 \%$ of those over 35 were afraid; $38 \%$ of those under 25 had not given the possibility serious consideration; $19 \%$ of those over 46 were unsure of their feelings

199 The very small occupational grouping labelled "other" had a high rate of fearfulness $(65 \%)$; I suspect that these individuals worked in areas that they knew were likely to be targeted for redundancies.

200 The 1991 census showed that there were 163,770 unemployed people in New Zealand, Population Overview ,p. 45 
their work, generally illustrated that a good proportion of the staff, despite acknowledged fears, did not believe that unemployment figures made any difference to the way they approached their paid employment.

Table 12: Affect of unemployment figures on way staff approached their paid employment.

(Respondents were able to give more than one response to this question so percentages are based on the total responses)

\begin{tabular}{||c|c||}
\hline \hline & Total percentage of all responses \\
\hline $\begin{array}{c}\text { It makes little or no difference to my } \\
\text { work }\end{array}$ & 35 \\
\hline $\begin{array}{c}\text { I keep an ear open for other } \\
\text { opportunities }\end{array}$ & 22 \\
\hline I work harder to keep my job & 17 \\
\hline $\begin{array}{c}\text { I work harder and make sure people } \\
\text { know how useful I am }\end{array}$ & 11 \\
\hline
\end{tabular}

It is reasonably significant that a significant number of the staff of both organisations were keeping an ear open for opportunities outside their places of employment. The likelihood of finding work elsewhere during times of high unemployment, especially if it was in a specialised field, was probably doubtful. It is not just those out of work who find it difficult to find employment, but even those in work who are wanting to further their career or to have a job change, find occupational choice is usually curbed at such times. ${ }^{201}$ Unemployment has repercussions for not just those out of work.

201 Clarke, p. 69 
The recognition of the effect of unemployment had become an issue for psychologists, community workers and others, by the early 1980 s, resulting in much of the research on the significance of work itself. Acceptance that the inherited work ethic of the western world, with its adulation of the worker, and moral condemnation of those who do not work ${ }^{202}$ coloured the outlook of many people towards the unemployed, raised important questions about the adequacy and appropriateness of the continuing application of such a concept.

In a society where access to regular earned income is culturally of great consequence, the unemployed become symbolically worthless in the economy. Their personal worth, self-respect, sense of human dignity and independence are all displaced. ${ }^{203}$ When an individual's identity of self is questioned, and the narrative of their personal biography interrupted, ${ }^{204}$ their whole life is fractured. Having a job not only provides a person with work to do, but gives them a role to fulfill in life, which Roger Clarke has called a lifescript. ${ }^{205}$ The destruction of this lifescript through unemployment is a major challenge for the person concerned, as it appears that there is no model of dignity in our society except for that derived from being in paid employment. ${ }^{206}$ When even a Royal Commission agrees that employment is a primary vehicle for making a contribution to

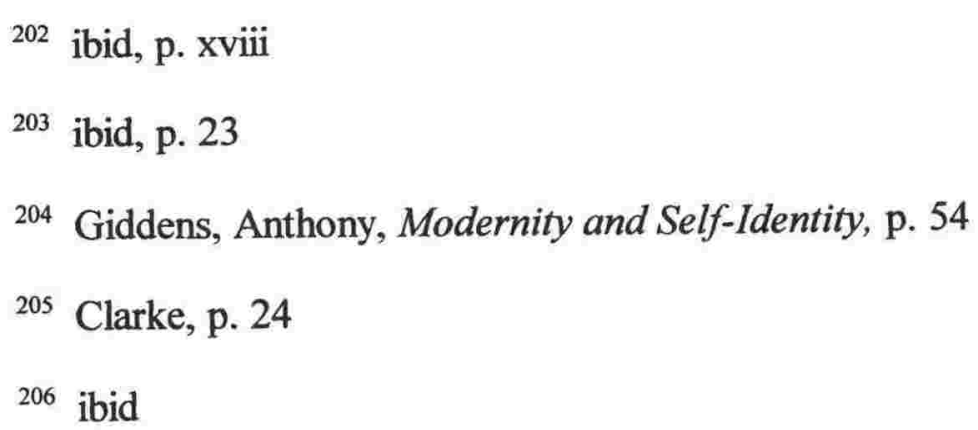


society, ${ }^{207}$ and gives people a sense of belonging and esteem, ${ }^{208}$ then hope of an alternative model or philosophy of dignity presenting without paid work at its centre, seems dim.

Society's possibly unconscious, subliminal adherence to a work ethic that blames the unemployed for their own predicament, as well as the official endorsement of this viewpoint, led to myths abounding in New Zealand in the late 80 s, early 90 s, about the unemployed. ${ }^{209}$ However, when asked if they believed that people who are unemployed are lazy and simply bludge off the State, MAF and DSIR GEO staff showed a reasonable tolerance to the unemployed. ${ }^{210}$

(See Table 13 on next page)

207 Royal Commission on Social Policy, Future Directions, Vol. II, p. 485

208 ibid

209 As covered in Chapter 5

${ }^{210}$ I have no explanation for the organisational differences that showed up in the results. The reasonable tolerance towards the unemployed possibly comes from a recognition that unemployment is a feature of economic downturn rather than personal failure, especially in light of the numbers of their colleagues they had seen made redundant who then struggled to find further employment. Younger people under 25 years of age, surprisingly, were more intolerant than their older colleagues, with $12 \%$ believing the unemployed were often lazy 
Table 13: Are the unemployed lazy?

(Percentages given are for responses on an organisational basis, and for the total number of responses)

\begin{tabular}{||c|c|c|c||}
\hline \hline & MAF & DSIR & $\begin{array}{c}\text { Total percentage } \\
\text { response }\end{array}$ \\
\hline Often & 8 & 2 & 7 \\
\hline Sometimes & 76 & 76 & 75 \\
\hline Rarely & 14 & 23 & 17 \\
\hline Never & 1 & 1 & 1 \\
\hline
\end{tabular}

A dimension of unemployment that encroaches upon the individual's well-being is that of the meaning of time and the way that society expects it to be structured. In an article on how managers cope with prolonged unemployment, it was observed: -

The unemployed individual is prevented from organizing time positively because "justifiable" non-working periods are typically given their valuation through work: coffee-breaks, weekends, vacations, periods of business-related travel, illness, recuperation and retirement are all defined in relation to one's status as a working individual. Unemployment, unhappily renders free time "unjustified", an expansion of the underside of constant productive activity, of stolen moments of idleness that each working person engages in every day. ${ }^{211}$

Accompanied by the attitude that still equates unemployment with voluntary idleness, this concept of "unjustifiable free time" parallels the traditional work ethic notion that all work is good and all leisure bad. ${ }^{212}$ Not utilising time in a "useful" way can lead to feelings of guilt, for not only the unemployed, but for the worker who is taking the time

211 Budge, Scott, \& Janoff, J., How Managers Face Prolonged Job Loss, Business, 34(2), 1984, p. 29, cited in Newman, Katherine S., Falling From Grace: The Experience of Downward Mobility in the American Middle Class, p. 63

212 Furnham, Adrian, The Protestant Work Ethic. The Psychology of Work-Related Beliefs and Behaviours, p. 56 
to relax away from his job. Workaholics in particular are said to suffer tremendous guilt when they are not working, ${ }^{213}$ and to fear that they will be branded as lazy if they take some leisure time. ${ }^{214}$ Guilt as one Christian psychologist has commented, is a complex emotion.

It is a mixture of many emotions and thoughts which destroy inner peace. It is partly the unpleasant knowledge that something wrong has been done. It is fear of punishment. It is shame, regret, or remorse. It is resentment and hostility toward the authority figure against whom the wrong has been done. ${ }^{215}$

In light of the fact that leisure or "unjustifiable free time" can induce these sort of emotions in people imbued with the work ethic, MAF and DSIR GEO staff were asked if they experienced such guilt if they were not "doing something".

Table 14: Guilt

(Percentages are given for responses on an organisational basis, and for the total number of responses.)

\begin{tabular}{||c|c|c|c||}
\hline & MAF & DSIR GEO & Total responses \\
\hline $\begin{array}{c}\text { I feel guilty if I am not } \\
\text { doing something }\end{array}$ & 42.2 & 25.4 & 37.2 \\
\hline $\begin{array}{c}\text { I do } \text { not feel guilty if I } \\
\text { am doing nothing }\end{array}$ & 6.3 & 9 & 7.3 \\
\hline $\begin{array}{c}\text { It depends on the } \\
\text { situation as to whether } \\
\text { I feel guilty about } \\
\text { doing nothing }\end{array}$ & 51.3 & 64.8 & 55.3 \\
\hline
\end{tabular}

${ }^{213}$ Killinger, p. 106

${ }^{214}$ ibid, p. 96

215 ibid, citing Quentin Hyder. 
Given previous statistical results that indicate MAF and DSIR GEO staff exhibited a moderate to strong work ethic, these responses are not unforeseen. What is surprising are the organisational differences in responses. ${ }^{216}$ The age factor might have been expected to influence how individuals responded but it appeared that regardless of age levels of guilt were relatively evenly spread. ${ }^{217}$

Given this relatively high level of guilt, what did respondents do with their time when they were not working? Leisure, prior to the 1980 s, had not been a subject much pursued by social scientists in New Zealand. ${ }^{218}$ Popular perceptions that New Zealanders were highly involved in sporting activities and outdoor pursuits in their leisure time were disproved by surveys in the 1970 s, which showed that home-based and social activities were far more likely to be popular than sport and cultural events. ${ }^{219}$ The results from the MAF/DSIR survey echo those done in the 1970 s, even though it is twenty years later. MAF and DSIR GEO staff were not given many choices in the questionnaire about their leisure activities but were given the opportunity to list for themselves their hobbies and involvements in clubs and organisations. These ranged

\footnotetext{
${ }^{216}$ Other results directly concerned with assessing the strength of work ethic traits were evenly spread over the two groups, making no distinction between organisations necessary.

${ }^{217}$ This also surprised me as I had expected to find older staff demonstrating higher levels of guilt than younger ones. Interestingly the under 25 's gave a $62 \%$ response to feeling guilty depending on the situation, which was only $1 \%$ less than the over 56 's. None of the under 25 's admitted to feeling not guilty about doing nothing.
}

218 Godlow, Bob; Perkins, Harvey; Cushman, Grant; Simpson, Clare, Leisure, in Spoonley, p. 242. The authors go on to say that very little research had been done in New Zealand about leisure by 1990. (p. 257)

219 ibid, p. 247 
over a wide scope of activities from music, crosswords, astronomy, dancing, gardening (a high proportion), collecting things, jam making to window shopping; from service or sports clubs, welfare organisations, dog clubs, school and kindergarten committees, Lodges, the RSA to church groups.

Table 15: Away from work activities.

(As respondents were asked to indicate as many activities as were appropriate for them, percentages are for the total number of responses, rather than the number of people responding.)

\begin{tabular}{||l|c||}
\hline & Percentage of total number of responses \\
\hline Working part-time for another employer & 1.5 \\
\hline Working around the house & 25 \\
\hline With friends/family & 25 \\
\hline Playing sport & 13 \\
\hline Doing some hobby & 15 \\
\hline Involvement with clubs and \\
organisations & 13 \\
\hline Doing voluntary work & 5 \\
\hline Other & 2.5 \\
\hline
\end{tabular}

The comment has been made that many so-called leisure pursuits seem to be the very embodiment of work ethic virtues. ${ }^{220}$ The above results, plus the many examples of activities given by respondents, help demonstrate that a high proportion of "out-ofwork" endeavours are in reality still about work, unpaid and unrecognised as work though it may be. The difference is that these activities are presumably done for

${ }^{220}$ Furnham, p. 56 
pleasure.

While the intensity surrounding the meaning of work over the last three decades has resulted in a tendency to ignore issues about leisure, it has been observed by one New Zealander decrying our lack of leisure, that people no longer know how to do nothing, since full and constant employment has become their ideal. ${ }^{221}$ This statement in itself seems to contradict the image of a poor work ethic in New Zealand and to point to a level of work reminiscent of the nineteenth century settlers when work was interminable and steady, although, as has become clear, work in the late twentieth century has evolved into something quite different.

This evolution of a fresh understanding about work, accompanied by the incongruity of growing unemployment, led to a recognition internationally and regionally, by theologians and churches that their traditional understandings about work also needed to be re-examined. The ideology of work was ready to go under the ecclesiastical microscope and be questioned as it had not been since the Reformation.

221 Collins, Chris, Playing for Real: Leisure and the Way we Live, Directions, No. 4, November/December, 1989, p. 2 


\title{
CHAPTER 8
}

\section{"The Lord God took the man and put him in the garden of Eden to till it and keep it"1 - Protestant Work Ethic or a theology of work?}

\begin{abstract}
Although human beings have always worked, the church came very late in the day to appreciate the prominence of work in people's lives. ${ }^{2}$ A self-consciousness ${ }^{3}$ about work was not to emerge until well into the Industrial Revolution, when work came to be regarded as a theological problem because of the novelty of the methods of work, the exigencies of mass production, the social consequences and finally, the church's socalled loss of the working class. ${ }^{4}$ The ideology of work that evolved at this time supported the growth of an industrial, capitalist system, with the Church facilitating in this development by encouraging a notion of the sacredness of hard work. ${ }^{5}$
\end{abstract}

It was only after the Second World War ${ }^{6}$ that theologians and ecclesiastical bodies began to finally take a serious interest in the significance of work for human kind, as opposed to promoting an ideology supporting the status quo of the work ethic of earlier

${ }^{1}$ Genesis 2:15 (NRSV)

2 Davis, Howard, \& Gosling, David, Will the Future Work? Values for emerging patterns of work and employment, p. 74

${ }^{3}$ Bleakley, (1983), p. 77, citing R. A. Markus

${ }^{4}$ ibid, citing Markus

${ }^{5}$ Chapter 2 has examined this issue at length.

${ }^{6}$ Nelson, John Oliver (ed), Work and Vocation, p. 18. Miroslav Volf, Work in the Spirit, p. 69, comments on the amazingly little theological reflection on work done prior to the 1980 s. 
years. Ironically by the time serious theological attention began to be given to the issue of work one writer could reflect: -

The modern theology of work attempts to give meaning to work precisely at a time when it appears to have become meaningless through industrialisation. Its hope that industrialisation will further the creative and productive purpose within the human nature overlooks the fragmentation of work that has occurred. $^{7}$

Clearly the changes wrought in the work place in the twentieth century as industrialisation was further complicated by technology, meant that the limited reflection on work from a prevoius age had little application in conceiving a contemporary theology of work. Initially it appears those attempts to address a theology of work were grounded in what has been described as the distinctively bourgeois conception of work, ${ }^{8}$ that is, the equivalent of Weber's Protestant Work Ethic with its moralistic elements and suggested sanctification through hard work, perseverance and frugality. No attempt was made to correlate the economic and human potential of work, or to contemplate any possible connection with the divine ordering of the world. ${ }^{9}$ M. D. Chenu in his influential book The Theology of Work, remarks of those few theologians who had considered the issue of work within the realm of capitalism, that: -

For too long they have confined themselves merely to advocating moderation of profits. The sternest criticism of capitalism never went beyond these limits. Now theology can advance further than this purely moral aspect, and base itself, in a human and Christian economy, on the physical density of work as

${ }^{7}$ Fiorenza, Francis Schussler, Religious Beliefs and Praxis: Reflections on Catholic Theological Views of Work, in Baum, (ed), p. 97

8 ibid, p. 96

${ }^{9}$ Chenu, M. D., The Theology of Work, pp. 3- 4 
part of the fabric of the world. ${ }^{10}$

Chenu himself however, made the assumption that industrialisation had led to an estrangement from the value of work for human beings, and that as work no longer had any human significance, it could not have a religious one. ${ }^{11}$ Any theological restoration of work to its former integrity he claimed, must therefore involve the reestablishment of work in its cosmic and human functions, and in the design of God the creator. ${ }^{12}$ His emphasis on purely theological tenets, in turn led to criticism from later theologians who recognised the need to also examine the social and economic situation of work. ${ }^{13}$ Questions began to be raised about the value of abstract theological affirmations which minimised the negative aspects of work and overlooked the drudgery of much industrial employment which in actuality dehumanised workers, ${ }^{14}$ and challenges were addressed against an ideology of work that had been earlier sanctioned by religion to allow an exploitative or oppressive distribution of labour. ${ }^{15}$

Increasingly, the traditional doctrine of sanctification of work that had undergirded any
10 ibid, pp. 10-11
11 ibid, p. 16
12 ibid
13 Fiorenza, in Baum, (ed), p. 98
14 ibid
15 ibid, p. 99 
pre-twentieth century theological deliberation on work ${ }^{16}$ was cast aside as an appropriate starting point for a new theology of work, but it took the work crisis of the 1980s to finally catapult the question of work into the real theological and ecclesiastical limelight. ${ }^{17}$ Issues surrounding unemployment, in societies dominated by work, resulted in churches and their scholars putting the problem of work high on their agenda. ${ }^{18}$ While the dilemma of unemployment was the final catalyst for a burgeoning of theological thought, changing attitudes towards work also provided stimulus. The study of work by the social sciences, consciously or inadvertently infiltrated into theological thinking, and the importance of work to the human psyche was finally acknowledged by theologians ${ }^{19}$ as being just as important as spiritual reflection.

While it was appreciated that basing a theology of work only on the Christian scriptures was of limited value in the modern world, ${ }^{20}$ it was also recognised that in trying to establish some theological insights into the nature and world of work, theBible had to be examined. ${ }^{21}$ One scholar is cited as describing the biblical resources as displaying inconclusive fragmentariness ${ }^{22}$ in their relation to work, but another went as far as to

${ }^{16}$ Volf, p. 71

${ }^{17}$ ibid, p. 4

18 ibid. (New Zealand churches can be included in this statement, although to a great extent their emphasis was only on the problem of unemployment and the relevance of the Protestant work ethic, rather than on developing a comprehensive theology of work.)

${ }^{19}$ Bleakley, (1983), p. 76

${ }^{20}$ Volf, p. 77

${ }^{21}$ Ballard, (1982), p. 32

${ }^{22}$ Cited in Bleakley, (1983), p. 80. (Bleakley does not name the scholar concerned) 
say, The Bible has a great deal to say about work...It is a book written by workers, written about workers, written to workers. ${ }^{23}$

Undoubtedly there are difficulties in trying to define the meaning of work from the Bible, primarily because of the broad understanding. Alan Richardson in his study, The Biblical Doctrine of Work, comments that the concept of work in the Bible: -

includes everything from the activity of God in the creation to the toil of the meanest slave. The same word is used in the Old Testament to cover work, effort, labour, toil, service and even worship. ${ }^{24}$

It appears that the "work" of God, human work, and the work of Christ (Phil. 2:30), are the three principle connotations of work in the scriptures, ${ }^{25}$ indicating that work needs to be considered in a broader context than simply daily work. ${ }^{26}$ There is a pervasive and unquestioned assumption that work is a part of the divinely ordered structure of the world and of human nature, ${ }^{27}$ and therefore it has been given a positive value in terms of human activity.

There is an inherent understanding in the Old Testament that work is God's intention for humanity; that by their very nature human beings are workers. ${ }^{28}$ The misinterpretation

${ }^{23}$ Engstrom, Ted, \& Juroe, David J., The Work Trap, p. 42

${ }^{24}$ Richardson, Alan, (1952), The Biblical Doctrine of Work, p. 13

25 ibid

${ }^{26}$ Ballard, (1982), p. 40

27 Richardson, Alan, (1952), p. 23

28 ibid, pp. 24-5 
of Genesis story of the Fall, which has been construed as resulting in a curse upon work, ${ }^{29}$ ignores the fact that God had already assigned humanity to work well before the episode with the serpent and the apple. In the first version of the creation story, God commanded Adam and Eve to fill the earth and subdue it, (Gen.1:28, NRVS), allowing a significant area of work for man in bringing creation to completeness of order. ${ }^{30}$ The second account of the creation story has Adam placed in the garden of Eden to till it and keep it,(Gen. 2:15, NRSV) before God has even created the animals and birds, or the woman. One biblical scholar has suggested that this command signifies vocation. ${ }^{31}$

The human creature is to care for and tend the garden. The word pair, "till and keep", may suggest a gardener or a shepherd. In either case, work belongs to the garden. Work is good, surely, to enhance the garden. From the beginning of human destiny, God is prepared to entrust the garden to this special creature. From the beginning, the human creature is called, given a vocation, and expected to share in God's work. ${ }^{32}$

The man was then given the assignment of naming the animals and birds as God formed them (Gen. 2: 19) - this commission of classifying the living creatures has also been described as work. ${ }^{33}$ In a sense it could even be said that the creation of Eve as helper (Gen. 2: 20), was about God's mandate of work for humanity. Instead of working in glad co-operation with God, however, humankind's disobedience led to work becoming laborious and uncongenial. (Gen. 3:17-19) With the curse upon the soil, work became

29 Richardson, Alan, (1953), Genesis $I$ - XI, p. 65, comments that Gen.2:15 should dispose entirely of the notion that the Bible teaches that work is a curse.

${ }^{30}$ Davies, John B., Beginning Now, p. 87

${ }^{31}$ Brueggemann, Walter, Genesis, p. 46

32 ibid

${ }^{33}$ McInnes, John, The New Pilgrim, p. 137 
necessary for survival. ${ }^{34}$

Throughout the rest of the Old Testament the presumption that work is an inevitable part of life is found in the narratives, wisdom literature and the books of the prophets. Humanity is expected to accept the laboriousness of work without complaint and to cheerfully fulfill God's intention for human existence. ${ }^{35}$ All work is deemed important with no distinction in the value of different types of work, ${ }^{36}$ and rather than being seen as a curse, it is regarded as a blessing. ${ }^{37}$

The New Testament however, does not have a great deal to say about work in this sense. Passing references are often made to a person's trade or profession but work itself is not a major issue, ${ }^{38}$ though Jesus frequently told parables based around people's work. ${ }^{39}$ The fact that Jesus himself is commonly believed to have worked as a carpenter was not seen as an issue to be dwelt on by the Gospel writers. As Richardson points out, For them the work of Jesus is not his work as craftsman but as redeemer of the

34 It has been suggested by Gerard von Rad in his commentary, Genesis, that although work was ordained for humankind in 2:15, it makes life so wretched, that it is so threatened by failures and wastes of time and often enough comes to nothing, that its actual result has no relation to the effort expended - that the narrator designates as a dissonance in creation which is not accounted for in God's original ordinance. (p. 95)

35 Richardson, Alan, (1952), p. 23

${ }^{36}$ Ballard, (1982), p. 37

${ }^{37}$ Richardson, Alan, (1952), p. 27

${ }^{38}$ McInnes, p. 139

${ }^{39}$ Marshall, Paul, Vocation, Work, and Jobs, in Marshall et al, p. 2. Marshall mentions the parable of the sower (Matthew 13:3), reapers, (Matthew 13:30), housebuilders (Matthew 7:24), swine tending (Luke 15:15), vineyard keeper (Mark 12: 1) 
world $^{40}$ The Roman Catholic Encyclical Laborem Exercens issued by Pope Jean Paul II, on the other hand, makes an astonishing claim based on the fact that Jesus had himself been a workman.

Jesus not only proclaimed but first and foremost fulfilled by his deeds the "gospel," the word of Eternal Wisdom, that had been entrusted to him. Therefore this was also the "gospel of work", because he who proclaimed it was himself a man of work, a craftsman like Joseph of Nazareth. (Mt. 13:55) And if we do not find in his words a special command to work -... at the same time the eloquence of the life of Christ is unequivocal: he belongs to the "working world, " he has appreciation and respect for human work. ${ }^{41}$

The Encyclical goes on to claim that the apostle Paul echoed the teaching of Jesus about work, ${ }^{42}$ although Paul never developed what could be described as a systematic teaching about work. ${ }^{43}$ Generally Paul spoke about work in quite ordinary ways, often referring to manual labour, and his own work as a tentmaker, but he also gave many exhortations on work, (e.g. 1 Cor. 4: 12; 15:10; Gal. 4:11; Col. 1:29), and a sustained attack against idleness. ( 2 Thess. 3: 6-13) There was no doubt that he saw work as a necessity, but also as an activity that originated in faith, for he made few distinctions between spiritual and physical work. ${ }^{44}$ In reality the concept of work in the New Testament, as presented by both Jesus, and later, Paul, alluded more to the furtherance of the Gospel and the service of the purpose of God $^{45}$ than the actual performance of physical labour as

40 Richardson, Alan, (1952), p. 31

41 Jean Paul II, Laborem Exercens, p. 90. In contrast, Volf, p. 93, emphatically denies that there is a "gospel of work" in the New Testament.

42 ibid, p. 92

${ }^{43}$ Marshall (et $a$ ) $)$, pp. 2-3

44 ibid, p. 3

45 Richardson, Alan, (1952), p. 33 
ordained by God.

Despite the ambiguity, and the relative scarcity of Biblical material, a contextual reading of the Bible, accompanied by an exploration of any contemporary relevance regarding statements about work, has led to a semblance of consensus among theologians regarding the importance and meaning of work. Firstly, work is unique to humans and is meant to be ennobling. As the only creature created in God's image, humankind has a specific divine mandate to work. It is humanity's way of being and becoming, ${ }^{46}$ as through work man not only transforms nature, adapting it to his own needs, but he also achieves fulfilment as a human being and indeed, in a sense, becomes 'more a human being ${ }^{\prime 47}$ Work is necessary, not only because God commanded it, but also because it sustains and develops humanity. ${ }^{48}$ Without work humankind's basic needs of food, shelter and defence cannot be met, ${ }^{49}$ but the meaning of work cannot simply be about survival or it demeans the value of work. It must also be about self-realisation, or an affirmation of the individual's essence. ${ }^{50}$ For it is,

in work and through work we humans express our human essence. And over time we transform and evolve that essence - biologically, technologically, and also religiously... Work is not first of all what we do to 'make' a living. Work is human living - human being and human becoming. We are uniquely a species that lives by way of skill. It is by human skill that we establish our place upon

${ }^{46}$ Raines, \& Day-Lower, p. 14

47 Jean Paul II, p. 33

48 ibid, p. 59

49 Ballard, (1982), p. 43

${ }^{50}$ Moltmann, Jurgen, On Human Dignity, p. 54 
the earth and transform and perfect that presence. ${ }^{51}$

Through this expression of work, humanity is ennobled, ${ }^{52}$ but only if people are the subject of work, not the object. ${ }^{53}$ In Laborem Exercens, great emphasis is put on the importance of the subjective dimension of labour. A commentary on the encyclical explains that: -

What happens to the subject of work is more important than what this work produces. The dignity and honour which work communicates to people is derived not so much from the objective dimension, from their achievement, from the product of their hands and minds, as from the subjective dimension; it is ultimately man's engagement which counts, his fidelity to the call, his increasing sense of responsibility, his self-realization. In labour the transformation experienced by the subject is of greater value and importance than the object produced. ${ }^{54}$

Productive work, nevertheless, is essential to the primary responsibility faced by human beings of providing for their life in community. ${ }^{55}$

Secondly, work is about relationships and community. Individuals work with each other, and for each other, with work a blessing and a gift...toward the community. ${ }^{56}$ Society should benefit from the work of its members, and individuals ideally have a sense

51 Raines \& Day-Lower, pp. 15-16

52 Vanderloet, Edward, Why Work Anyway? in Marshall (et al), p. 39

53 Baum, Gregory, (1982), The Priority of Labour, pp. 13-15. According to Marxist analysis, economic theory tends to see the worker as an object involved in the production of goods or services.

54 ibid, p. 14

${ }^{55}$ Rendtorff, Trutz, Ethics (Vol. 2), p. 20

${ }^{56}$ Fox, Matthew, The Re-invention of Work: A New Vision of Livelihood for Our Time, p. 99 
of fulfilling their obligation to the divine mandate by performing useful work on behalf of the community around them. ${ }^{57}$ Through providing good and useful services to society, humans should find meaningfulness in their work, and in their community, for work is one way of discovering and understanding themselves in relation to the society they live in ${ }^{58}$ Ultimately, because God has proclaimed work as the way humankind must provide for its survival, work needs to be seen as a manifestation of the social nature of life itself. ${ }^{59}$ Work is essential to the very meaning of life and society, a foundation necessity of society. ${ }^{60}$ Yet the claim is made that work is not meaningful in and of itself. $^{61}$ Work, it has been said: -

sustains us, not because of the income it produces, but because the activity of working is basic to who we are as human beings: co-creators with God and with one another. ${ }^{62}$

Thirdly, the concept of humans as co-creators with God has been a recurrent theme for theologians, ${ }^{63}$ based on the biblical premise that God calls humankind into creative

${ }^{57}$ Obenhaus, Victor, Ethics for an Industrial Age, p. 205

${ }^{58}$ Ballard, Paul, (1987), In and Out of Work: A Pastoral Perspective, p. 13

59 Rendtorff, (Vol.2), p. 21

${ }^{60}$ Ballard, (1982), p. 54

${ }^{61}$ Bloomquist, Karen, L., The Dream Betrayed: Religious Challenge of the Working Class, p. 30

62 ibid

${ }^{63}$ Volf, p. 98 
partnership and co-operation with the divine. ${ }^{64}$ Linked to the command of stewardship over all creation, and the understanding that humankind is created in God's image, the notion that humans share in the work of the creator needs to be tempered with the statement that God's work is qualitatively different ${ }^{65}$ from that of humans. Co-creation does not mean humans do the same work as God - there is a definite limitation to human work: It must be done within the finitude of the created order. ${ }^{66}$ Nevertheless, within those limitations, humans are encouraged to develop and perfect their working partnership with God as they grow in knowledge about the resources and values embraced by the natural creation. ${ }^{67}$ The ability to use and develop our environment is a not only a component of the call to stewardship ordered by God, but is also a means by which we encounter the Creator in and through the creativity of our work within nature and history. ${ }^{68}$ According to the Second Vatican Council, even mundane, everyday work should be regarded as a participation in God's activities, on the basis that work benefits society if appropriately executed, and thereby contributes to the realisation in history of the divine plan. ${ }^{69}$ Further comment was later made by Pope Paul VI: -

Everyone who works is a creator. Bent over a material that resists his efforts, a man by his work, gives his imprint to it, acquiring as he does so,

${ }^{64}$ Ballard, (1982), p. 34. Ballard mentions not only the Genesis stories as indicating this partnership but also points to the Church as participating in the work of God (1 Cor.3:9; Mark 16:20), along with those called to apostolic office in the Church. (Eph.4:11)

${ }^{65}$ Meeks, M. Douglas, God the Economist, p. 137

66 ibid

67 Jean Paul II, p. 86

${ }^{68}$ Holland, Joe, Creative Communion. Toward a Spirituality of Work, p. 36

69 Jean Paul II, p. 88, referring to the 1966 Second Vatican Ecumenical Council's Pastoral Constitution on the Church in the Modern World, Guadium et Spes. 
perseverance, skill and a spirit of invention. Further, when work is done in common, when hope, hardship, ambition and joy are shared, it brings together and firmly unites the wills, minds and hearts of men. In its accomplishment, men find themselves to be brothers. ${ }^{70}$

An elemental urge to be creative appears to be inherent in all humankind although it is hard to see anything particularly creative about some of the work performed in the late twentieth century. However, creativity may be in relationships, communication, service, art or useful products, ${ }^{71}$ and in recognising this dimension of themselves, human beings begin to appreciate their partnership with God in the continual work of creation. An appendix to a Presbyterian Church of New Zealand report observes that the real purpose of work is, to bring the world into order, completion and fulfilment, and people express their humanity most authentically when they are engaged in this task. ${ }^{72}$ In participating as a co-worker with God, individuals are not only able to express their uniqueness in their use of the resources of the creation, but to also satisfy their economic, social and emotional needs, ${ }^{73}$ alongside serving the world and its peoples.

${ }^{70}$ Reports of Committees presented to the General Assembly of the Presbyterian Church of New Zealand, 1978, (Appendix to the Public Questions Committee Report), citing Pope Paul VI, p. 290

${ }^{71}$ Fox, p. 117, citing Harman, Willis, \& Hormann, John, from their book, Creative Work.

72 Reports of Committees, 1978, p. 289. In 1990 an occasional paper on The Nature of Work was distributed by the Presbyterian/Methodist Public Questions Committee, inviting comment, and asking for definitions of work. Five responses specifically mentioned the concept of creativity, or co-operation in creation, as part of their definition of work, although there was one submission which made it clear that the notion of human work helping in God's creative work was too much like theological jargon. (The 1990 Presbyterian Co-convenor of the PQ Committee, Nancy-Jean Whitehead, gave me access to the submissions)

73 ibid. 
It is clear that the precepts alluded to so far - human uniqueness, community and cocreation with God - are interconnected. Undergirding them is the fourth, and perhaps most discussed aspect of any suggested theology of work, that of call and/or vocation. As both theologians and social scientists searched for a fresh understanding of the meaning and nature of work relevant for the late twentieth century, the issue of vocation, from both theological and secular viewpoints, ${ }^{74}$ became vital in attempting to find meaningfulness in humankind's work. The belief emerged that in order to gain a fullorbed, properly nuanced and balanced view of the place of work in human life, it is imperative to recover the broad sense of vocation. ${ }^{75}$

Any endeavour to rediscover the definitive meaning of vocation inevitably leads back to the Reformation dictums formulated primarily in response to the medieval monastic ideal that devalued the worth of worldly occupations. ${ }^{76}$ Earlier discussion on Weber's representation of Luther and Calvin's interpretations of the concept of calling and vocation, show how he misconstrued some of their teachings to fit his hypothesis of the Protestant Work Ethic, ${ }^{77}$ but what was not mentioned was the fact that while the Reformers had essentially maintained the biblical understanding of the concept of calling, they had misinterpreted one of the key texts (1 Corinthians 7:20), and proceeded to filter

74 Ferguson, Marilyn, in The Aquarian Conspiracy, is one example of a secular writer who looked to the idea of vocation as being a possible vehicle for human transformation through work. (p. 375-377)

${ }^{75}$ Hardy, Lee, The Fabric of This World, p. 113

76 ibid, p. 45

77 See Chapter 1 
their perceptions through this faulty exposition. ${ }^{78}$ Contemporary theologians have gone on to not only reinterpret the scriptural basis of the Reformer's teachings, but also to reexamine their original conceptions of calling and vocation considering the way these maxims have been distorted with the changes in work since the sixteenth and seventeenth centuries.

One of the difficulties appears to be the definition of "calling" in relation to "vocation." Jurgen Moltmann observes: -

On theological grounds the call to be a Christian happened but once; it is irrevocable, immutable, and directed toward the coming glory. It admits one into the community of Christ and leads to the path of discipleship. Vocations, on the other hand, are historical, changeable, limited by time, and directed toward neighbour and society. Vocations are undertaken, shaped, and changed according to the call. ${ }^{79}$

The two terms are definitely not identical in meaning although each has implications that legitimately contribute to the other. ${ }^{80}$ The Reformers of the sixteenth century, however, took the text Let every man abide in the same calling wherein he was called (1 Corinthians 7:20 KJV) ${ }^{81}$ as signifying that "calling" in this sense meant the occupations and estates that Christians were already in. In essence, from Luther's point of view, their work, along with their place and station in life, was their calling, and although Calvin was more flexible about individuals changing their work, he nevertheless undoubtedly

${ }^{78}$ Marshall, in Marshall et al, pp. 12-13

${ }^{79}$ Moltmann, p. 47

${ }^{80}$ Minear, Paul, Work and Vocation in Scripture, in Nelson, p. 47

${ }^{81}$ It is interesting to note that NRSV translates this verse as Let each of you remain in the condition in which you were called, which immediately alters the emphasis. 
related calling to one's place in society and the economic order. ${ }^{82}$ Apparently, the understanding was that when an individual heard God's spiritual call, their station or profession was transformed into their vocation. ${ }^{83}$ Unfortunately this connotation of calling, which tended to be reduced to the activities of the individual in a particular position in society, became further corrupted over the centuries to mean little more than a type of job. ${ }^{84}$

In the attempts to redefine the idea of vocation to incorporate its original intention, biblical scholars have entered the discussion stating categorically that there is a radical difference between modern and biblical usage of the terms calling and vocation. ${ }^{85}$ No where in the Bible is there an instance of God calling a person to a specific earthly trade or profession as their vocation. ${ }^{86}$ It is important to acknowledge that the Biblical notion of vocation is a corporate one, not individualistic. The reality is that God calls a people Israel in the Old Testament, the community of the Church in the New Testament. ${ }^{87}$ It is within the corporate context of the people of God that the individual is called. One scholar comments: -

Wherever an individual was given a special mission, he was in one way or another carrying forward the mission of the whole community. Wherever the community was assigned a task, implicit in it was a vocation for every person

${ }^{82}$ Marshall, in Marshall et al, pp. 12-13

${ }^{83}$ Volf, p. 106

${ }^{84}$ ibid, p. 13

${ }^{85}$ Minear, in Nelson, p. 46

${ }^{86}$ Richardson, Alan, (1952), p. 35

${ }^{87}$ Heiges, Donald R., The Christian's Calling, p. 21 
within the community... ${ }^{88}$

The New Testament has a three-pronged approach to the meaning of vocation integrating the corporate and individualistic aspect of calling. Firstly, there is the understanding that God calls people into the Church through repentance and faith in Christ; secondly, within the Church God calls certain people to perform certain specialised tasks; and, thirdly, all the members of the Church as the Body of Christ, are called to a life of sanctified community in all their relationships. ${ }^{89}$ The individual's employment or situation is irrelevant to this call to vocation as demonstrated by the wide range of people Jesus called as his disciples.

The importance of community in the context of calling was to some degree recognised by Luther in that he saw vocation as a specific call to love one's neighbour through the duties attached to one's specific station in life, ${ }^{90}$ but increasingly, as work changed, vocation became a personal service to God, not society, and the further the economic focus of work was removed from meeting the primary needs of human beings, the more difficult it became to make any connection between service to one's neighbour and one's work..$^{91}$ The search, however, to find a contemporary understanding of vocation, has resulted in an increasing awareness of the importance of community in the whole idea. In keeping with the notion of the world as a global village, John Raines and Donna Day-

${ }^{88}$ Minear, in Nelson, p. 49

89 Heiges, p. 41

${ }^{90}$ Hardy, p. 46

91 ibid, p. 102 
Lower made the following observations in their book, Modern Work and Human Meaning: -

We are an interdependent human community struggling toward a common goal: to make life on this planet decent, just, and indeed possible. Our work represents our contribution to such a future. And that future is not possible without the opportunity and commitment to contribute through vocation to the common good....Vocation restored to its original meaning and context could radicalize the way we think about our work, experience our jobs, and structure employment in the global society... Vocation is not individualistic but is drawn from the primary collective call. There is a shared and prior responsibility to the community; individual work is just an expression of that. ${ }^{92}$

Associated with the idea of vocation involving service to others, is the growing cognizance that God calls and equips people precisely to serve their fellow human beings. ${ }^{93}$ Everyone is gifted with charisms that are in some way appropriate to the purpose God has called them to fulfill in serving others. This adds new dimensions to the idea of calling and vocation with the suggestion that one can discover what work God is calling one to by reflecting on the gifts one has received, not simply by examining one's life-setting ${ }^{94}$ as was the understanding of the Reformation interpretation of vocation.

In proposing a reinterpretation of vocation that entails a theology of charisms as its foundation, ${ }^{95}$ in contrast to Luther's definition of a Christian's profession as a vocation,

\footnotetext{
${ }^{92}$ Raines \& Day-Lower, p. 108

93 Volf, p. 190; also Minear, p. 71

94 Volf, p. 199

95 ibid, p. 109
} 
theologian Miroslav Volf is breaking new ground. Critical of the original identification of vocation with thacall, and over subsequent years, of vocation with occupation, ${ }^{96}$ Volf comments that this movement has on one hand led to the elevation of work to the status of religion, ${ }^{97}$ and on the other, the enabling of dehumanizing work. ${ }^{98}$ Neither are valid and can be misused ideologically to promote an understanding of the meaningfulness of work that is unauthentic in terms of the biblical understanding of calling.

Jacques Ellul is another theologian who has been disparaging of the traditional Reformation based definition of calling and vocation, and he has gone as far as to deny that there was ever a connection between work and vocation. ${ }^{99}$ Work as such is not vocation, not a calling, ${ }^{100}$ Ellul states, but it is not simply the notion of work as vocation or calling that he questions. Ellul remarks that work has no ultimate value, no transcendental meaning, although he does acknowledge that work characterises us as human beings. ${ }^{101}$ Because it is impossible to therefore realize one's vocation or calling in the world of work, Ellul maintains that it would be misguided to try and change this world to allow the individual's pursuit of vocation within it. ${ }^{102}$

96 ibid, p. 107

97 ibid, p. 109

98 ibid, p. 108

99 Hardy, p. 103

100 Ellul, Jaques, Work and Calling, in Holloway, James Y., \& Campbell, Will D., Callings!, p. 29

101 ibid, p. 37

${ }^{102}$ Hardy, p. 104 
An additional reason for not attempting to seek one's vocation in the work place is the tendency towards specialisation and fragmentation of work. The contention is that: -

Modern work tends to fragment us, whereas vocation tends to nurture a sense of self as a whole. Modern work fractures and isolates people, even from themselves, whereas vocation demands that each discover and express who he or she is in Christ. ${ }^{103}$

The dilemma follows that tradition decreed that the individual should find their calling in an occupation. Any aspects of the individual expressed outside work were not to be regarded as vocation, but simply as irrelevant details of personal life. ${ }^{104}$ The person was therefore presumed to have only one calling, primarily to the occupation that they were expected to hold for their whole life. As vocation came to equate to job, the personal life of the worker became ever more inconsequential, and the fact that even Luther had recognised that individuals usually belonged to more than one situation, ${ }^{105}$ was ignored. However, contemporary theologians in trying to restate the relevance of vocation for a convincing theology of work for the late twentieth century, have realised that while work may be one thing the individual is called to do, vocation has many facets. ${ }^{106}$ It might be that a person's vocation has nothing to do with his or her work, and is external

${ }^{103}$ Vest, Norvene, Friend of the Soul. A Benedictine Spirituality of Work, pp. 30-1. Volf also points out that the increasingly mobile industrial and information society does not lend itself to the Reformation understanding of vocation because a plurality of jobs is in direct contrast with Luther's avowal of the singleness and permanence of each person's calling. (p. 108)

104 Hardy, p. 113

105 Volf, p. 109

106 Hardy, p. 112 
from their occupation. ${ }^{107}$

In light of the considerable theological discussion about vocation, staff at MAF and DSIR GEO were asked to show in the 1991 survey how they perceived their work. Given that $52 \%$ of the total respondents indicated they had some religious affiliation ${ }^{108}$ it might have been expected that a reasonable number would have confirmed that they saw their work as their vocation but this was not the case as Table 16 shows, with only $9 \%$ of those responding giving this answer. ${ }^{109}$ Age definitely had a bearing on how individuals perceived their work, with $65 \%$ of those over 56 years responding that they saw their job as a vocation, with a further $9 \%$ in this age group indicating they saw their job as their life work. Obviously the older the respondents the more likely they were to see their work in these terms. The other significant age related response was that $20 \%$ of those under 25 years felt their job "was just a job."

(See Table 16 on the next page)

107 Reports of Committees to the General Assembly of the Presbyterian Church of New Zealand, 1957, Public Questions Committee Report, p. 179a

108 See Appendix 5 for the data on religious affiliation.

109 Unfortunately I did not think to ask for a correlation between religious affiliation and how this question was answered. 
Table 16: How respondents perceive their work.

(Total percentages of responses are given. There were a high number of invalid responses for this question )

\begin{tabular}{||c|c|c|c||}
\hline & MAF & DSIR GEO & Total \\
\hline Vocation & 10 & 8 & 9 \\
\hline Life work & 3 & 7 & 4 \\
\hline Chosen career & 29 & 36 & 31 \\
\hline Self-imposed task & 4 & 5 & 4 \\
\hline $\begin{array}{c}\text { Provides my bread } \\
\text { and butter }\end{array}$ & 7 & 3 & 24 \\
\hline Profession & 26 & 20 & 6 \\
\hline Just a job & 7 & 3 & 6 \\
\hline Other & 5 & 7 & \\
\hline
\end{tabular}

Occupational class made a difference to the way people responded to this question.

In the three occupational classes common for each organisation, there were considerable variations, both between classes and organisations. ${ }^{110}$

Table 17: How managers perceived their work.

(Only percentages for significant perceptions have been given.)

\begin{tabular}{|c|c|c|}
\hline & MAF & DSIR GEO \\
\hline Vocation & 18 & 30 \\
\hline Career & 18 & 20 \\
\hline A profession & 39 & 30 \\
\hline
\end{tabular}

110 It would have been useful to have correlated occupational classes with age, but unfortunately this was not done. From my personal knowledge of the DSIR GEO managers I would suggest they were possibly in an older age group to their MAF counterparts which may account for their choice of "vocation " as their perception of their work. 
Table 18: How management support staff perceived their work (Only percentages for significant perceptions have been given)

\begin{tabular}{||c|c|c||}
\hline \hline & MAF & DSIR GEO \\
\hline Vocation & 12 & - \\
\hline Career & 33 & 44 \\
\hline A profession & 24 & 11 \\
\hline $\begin{array}{c}\text { Provides my bread and } \\
\text { butter }\end{array}$ & 5 & 17 \\
\hline
\end{tabular}

Table 19: How technical staff perceived their work

(Only percentages for significant perceptions have been given)

\begin{tabular}{|c|c|c|}
\hline & MAF & DSIR GEO \\
\hline Vocation & 7 & 9 \\
\hline Career & 29 & 39 \\
\hline A profession & 28 & 21 \\
\hline Life work & 6 & 10 \\
\hline
\end{tabular}

The diminishing of any sense of vocation among workers is not an isolated event. If public servants, who have been identified by at least one writer as among the last secular workers to be able to claim a sense of vocation, ${ }^{111}$ explicitly disregard the notion, ${ }^{112}$ they are only symbolic of many other workers who have transferred the meaning of work

${ }^{111}$ Meeks, p. 139

112 This group of nearly 500 New Zealand public servants may be only a small sample but even given considerable room for statistical deficiencies, it appears that it is unlikely that a majority of public servants in this country would claim to perceive their work as a vocation. 
from individual vocation to a means of simply earning a living, ${ }^{113}$ and/or possibly finding personal satisfaction and fulfilment. In attempting to find an explanation for this diminution of vocation, theologians have turned to the work of Karl Marx,,${ }^{114}$ where they have found an explication of work that corresponds to an unexpected degree with the "new" Christian theology of work. ${ }^{115}$ In the midst of Marx's critique of capitalist society theologians also found an analysis of the alienation that humans experience when their work is reduced to mere labour that can be replaced at any time. In this environment as one writer points out, it is not possible to find any sense of obligation in the sense of vocation. ${ }^{116}$ Marxist interpretation establishes that: -

Work is alienating when it is only a means and not an end in itself. First, human beings can enjoy work only when they, at least partly, do it for its own sake. If work is a mere means then people do not work because they enjoy working but because they cannot survive without working. Work is then a form of forced labour. ${ }^{117}$

In theological terms this idea of alienation has been transformed into the notion of "good" and "bad" work. The reduction of work to oppression and drudgery, or to a destructive force that dehumanises people and helps destroy the creation through

113 Rendtorff, (Vol. 2), p. 45

${ }^{114}$ For example, Hardy, pp. 29-33; Maduro, Otto, Labour and Religion According to Karl Marx, in Baum, (ed), pp. 12-20; Volf, pp. 55-61, Meeks, p. 144

115 According to Volf, Marx saw work as a social activity through which humankind finds self-actualisation, and humanises nature. (p. 57) While the primary purpose of work is to secure human existence, Marx believed that through work humanity develops its potential. (p. 58) Marx considered work to be an eternal necessity (p. 59), and humanity's life expression.(p. 59)

${ }^{116}$ Rendtorff, (Vol. 2), p. 46

117 Volf, p. 59 
pollution and misuse of natural resources, can be distinguished as bad or "evil" work. ${ }^{118}$ Such work has been described as an intense problem ${ }^{119}$ because it assaults that which is essentially human within us.

Bad work deprives us of a sense of personal investment in the product of our labour. In bad work we do not know ourselves as living in and through our work, we live only while we are away from work; while we are at work we seek only to endure. ${ }^{120}$

When workers complain that their work has destroyed their health, and their family life; that their work is boring and demeaning; that they have no power in the work place or control over their work; ${ }^{121}$ that they are ridiculed and humiliated by those in the work place who have become petty and officious, ${ }^{122}$ then they are describing "bad" work that is literally dehumanising.

The ultimate manifestation of "bad" work, and humanity's alienation from good and authentic work, can be designated as the workaholism described in the last chapter. Although society and the traditional Protestant work ethic appear to reinforce the addictive behaviour shown by the workaholic, from a contemporary theological viewpoint, workaholism estranges us from our deepest selves and prevents us from asking deeper questions about our vocation and purpose in living. ${ }^{123}$ As long as

\footnotetext{
${ }^{118}$ Holland, p. 37

119 Raines \& Day-Lower, p. 16

120 ibid

121 Meeks, pp. 128-9

122 Raines \& Day-Lower, p. 16

${ }^{123}$ Fox, p. 11
} 
individuals are so busy that they are not asking if the work they are doing is "the right work" for them, they are not only estranged from themselves, but they are alienated from the work that is good for them and the universe. ${ }^{124}$

At the heart of the alienation of work, is the estrangement of work from the divine. With what Matthew Fox has described as the desacralization of work, ${ }^{125}$ secular work became profane. ${ }^{126}$ Responsibility for this lies firmly in the economic structure of laissez faire, or free market capitalism, and the division of labour within this system. Alienation, it has been said, is the price society has to be pay for being economically advanced. ${ }^{127}$ Economists, in response, claim that the religious dimensions of life have nothing to do with economics, ${ }^{128}$ but increasingly from the 1970 s on, particularly as unemployment rates soared, theologians have disagreed. By the late 80 s even the editor of Harvest Field, magazine of the Association of Presbyterian Women in New Zealand, was calling for committed Christian economists to fundamentally rethink economics. The Church is called to be in the vanguard of the structural economic change, ${ }^{129}$ Presbyterian women were told.

The difficulties of persuading both economists and Christians that alienation from work,

124 ibid, p. 36, discussing the ideas of Diane Fussel, a specialist on workaholism.

125 ibid, p. 12

${ }^{126}$ Holland, p. 55

127 Volf, p. 54

${ }^{128}$ Meeks, p. 30

129 Ranby, Margaret, The Choice, Harvest Field, May, 1989, p. 5 
the exploitation of workers and the iniquity of unemployment, are faith issues, are rooted in a belief that economics and politics are outside the Church's résumé. In the past theologians have not been trained to see the connections between Christianity and economics, and generations of Christians have without question accepted a surreptitious use of the Christian faith as religious legitimatization of assumptions behind prevailing economic systems. ${ }^{130}$ The late E. F. Schumacher, one of the few economists to question the fundamental purpose for which the economy exists, believed:-

people unquestioningly accept economic systems as God-given and inevitable and allow themselves to become slaves to the economy and its needs rather than shaping economies to meet human needs. ${ }^{131}$

The foundation of this acquiescence to the economic system is based on the emergence of the economic forces of the sixteenth and seventeenth centuries, and the compliance of the Church of the day. ${ }^{132}$ The biblical precepts of neighbourliness and social responsibility were cast aside as irrelevant, or even counterproductive to the commercial goals of the early entrepreneurial capitalists, and instead, individualism became the norm. ${ }^{133}$ The disturbing presence of God, ${ }^{134}$ was also excluded from the late eighteenth century economic theory of Adam Smith, who quite deliberately drove a wedge between

130 Meeks, p. 19

${ }^{131}$ Randerson, Richard, (1987), Christian Ethics and the New Zealand Economy, p. 24

132 ibid, p. 12

133 ibid

134 Meeks, p. 48 
ethics and economics, ${ }^{135}$ through his argument that people who act in their own selfinterest in the free market can be far more trusted than those who act out of benevolence. ${ }^{136}$

From Smith's free market ideology emerged the belief that work primarily concerned the production of wealth. Miroslav Volf observes: -

In the modern world, participation in material production - whether by manual or intellectual work - has become the most significant form of work, due to the prevailing persuasion that economic activity holds the key to human happiness. ${ }^{137}$

Material wealth and consumption are supposed to provide this happiness, and although people supposedly work only to satisfy their material needs, there is in Smith's ideology, no dignity about this work. ${ }^{138}$ Work is simply seen as necessary to obtain purchasing power. ${ }^{139}$ The contention that wealth is the ultimate objective of work is faithfully maintained by economists espousing free market policies to this day, in one instance utilising scriptural justification to defend their application. The head of Margaret Thatcher's Policy Unit, Brian Griffiths', wrote in his book, Morality and the Market Place: -

There is a positive mandate to create wealth....It is God's intention that we cultivate it [ the physical world], improve it and harness its resources for our own use. man has been created to have dominion in this world...Prosperity, not

\footnotetext{
135 Raines \& Day-Lower, p. 19

136 ibid

137 Volf, p. 49

138 ibid, p. 50

139 ibid
} 
poverty, is God's intention for his world, though we must be careful to distinguish prosperity from luxury. In the Bible, therefore, economic life has a legitimacy, which derives from the nature of the created world. ${ }^{140}$

Griffiths' statement fits within an ideological religious response defined as legitimatising the existing social order, defending the dominant values, and enhancing the authority of the dominant class. ${ }^{141}$ In his unique study God the Economist, Douglas Meeks makes this comment about this ideological stance as it is utilised by the market economy.

Political theology recognizes that market society, far from eschewing God concepts, employs them ideologically precisely to justify conditions of domination that lie outside the market. Whereas the market rules themselves exclude God, the actual assumptions about the human being and society presupposed by these rules require certain ideologies that have made use of authoritarian God concepts. These God concepts are expressed in the complex forms of civil religion and in the public practices that surround the market. Concepts of God as dominator which belong to older social formations such as feudal, imperial, and tributary systems still appear in market ideology as a necessary element by which the dominant class explains to itself why it is and should be dominant. ${ }^{142}$

It is striking that at the end of the late twentieth century the Church is still largely defined within the parameters of the prevailing economy, ${ }^{143}$ and that there has been a powerful and widespread resistance, both inside and external to the Church, ${ }^{144}$ to

${ }^{140}$ Grffiths, Brian, Morality and the Market Place, p. 92. Griffiths goes on to proclaim that economic equality should not be a Christian concern, although the Christian should be involved in relieving poverty. (pp.95-6) He regards laziness to be one of the root causes of poverty defined in the Bible. (p. 96)

141 Randerson, (1987), p. 31,

${ }^{142}$ Meeks, p. 55

143 ibid, p. 37

${ }^{144}$ For example in New Zealand, Bob Jones, a free market promoter, was critical of the attack made by Cardinal Thomas Williams against Rogernomics. Jones stated, In making these utterances he was continuing a near 2000 years tradition established by his numerous clerical predecessors and that is of talking nonsense. (Jones, Bob, Wimp 
theologians and the church getting involved in such issues as economics, ${ }^{145}$ and expressing a so-called "utopian" response that reveals the ills of the present social order, inverts the dominant values of society, undermines the authority of the ruling groups. ${ }^{146}$

In New Zealand it was the Roman Catholic Cardinal, Thomas Williams, who finally challenged the apparent ideological stance of the local churches in 1988 , by speaking out against the Labour government's social and economic policies, in a statement firmly based in Catholic social thought. ${ }^{147}$ In doing so, he broke what had appeared to be the silence of the churches, and was supported in doing so by both the Anglican and Presbyterian Churches, who had been in reality also been examining the issues, but not receiving any public attention. ${ }^{148}$ The comment was made at the time that, despite Williams' censure of the government, there was a profound ignorance of the social and economic implications of both the Jewish and Christian faith ${ }^{149}$ in New Zealand, and that the churches had yet to grasp the importance of links between theology, economics

Walloping, p. 65) Jones goes on to say that, In speaking out on secular matters Cardinal Williams ignores the lessons of history as to the functional divide between Church and State. (p. 67)

145 Randerson, (1987), p. 27-8

146 ibid, p. 31, citing Gregory Baum

${ }^{147}$ Hucker, Brian, Churches Question Economic Policy, Accent, Vol. 3, No. 4, June, 1988, p. 11

148 ibid, pp. 11,13

149 ibid, p. 13 
and social sciences. ${ }^{150}$ Part of the predicament it was suggested, lay in the deep ideological entrenchment of the New Zealand churches in existing economic and social systems that made them timid in the questions which they raise. ${ }^{151}$ It seems likely, based on the observations of American writers like Meeks, that they were not alone in this timidity among the churches of the capitalist West.

Closely associated to the response of theology regarding issues surrounding economics and the alienation of work, is the problem of unemployment. Fundamentally unemployment is the ultimate alienation from work, resulting from a break down in the structure of an economic system that abandons workers and their right to work, seemingly without conscience. Described as a structural $\sin ,{ }^{152}$ unemployment is an attack on God's commission that humankind should work. In theological terms,

To deny someone necessary and fulfilling work is to deny that person's being created in the image of God. To deny people work is synonymous with saying that they are exchangeable cogs in the machine, that they do not deserve their co-creatorship, which unfolds in labour, praxis, and self-activity, that is, activity which realizes the essential powers of the self. ${ }^{153}$

The unemployed person is alienated from work, from co-workers, and humanity's historical project of co-creation with God. ${ }^{154}$ As the economic factors governing the employment of individuals changed over the latter years of the twentieth century, this

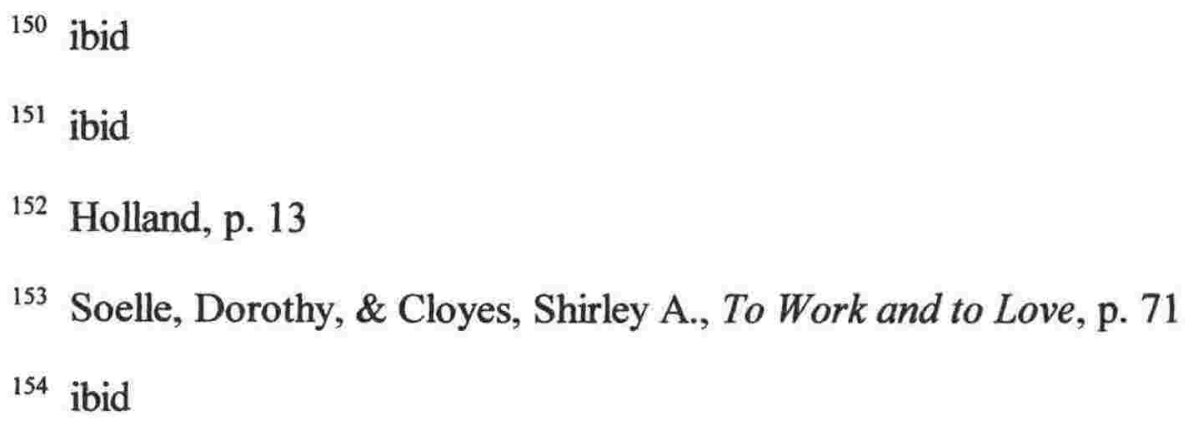


crisis of alienation was increasingly identified by churches internationally, and challenges were made to policy makers, in particular asking the question Who bears the burdens of structural adjustments to the economy ${ }^{155}$ The evil that is unemployment, it was recognised, demanded an obligation on the behalf of governments and those responsible for economic structures, to provide subsistence for those who found themselves out of work. ${ }^{156}$ This obligation found its origin in the fundamental principle of the moral order advocated by Judeo-Christian precepts, the principle of the common use of goods and the right to life. ${ }^{157}$

In New Zealand, dialogue in the churches about unemployment began in the late 1970s in the face of climbing unemployment figures unprecedented since the 1930s depression. The Public Questions Report of the Presbyterian Church, for example, commented in 1978: -

Conditioned as we are by an economic system which sees labour as something which can be bought and sold, it is common for all groups in society to view employment as primarily an economic matter. Thus one frequently hears discussions at government and managerial levels about what might be an "acceptable" level of unemployment - as if the lives of the thousands of people affected did not matter. It is also part of this conditioning that workers themselves will accept redundancy philosophically. They see themselves as economic units rather than as human beings who have a right and need to

155 The Roman Catholic Church in particular started to raise questions in the late 1970s as it became increasingly clear that unemployment was becoming a permanent feature of western economies. For example, the Catholic Commission for Justice and Peace, began consulting with the community about unemployment issues with the intention of issuing a Social Justice Statement in 1979. (Perkins, Harvey, \& Jill, The Unemployed - A Biblical Viewpoint, p. 20)

${ }^{156}$ Jean Paul II, p. 64

157 ibid 
express themselves in their work and find fulfilment in being creative. ${ }^{158}$

Over the next few years the issue of unemployment continued to receive attention from Methodist-Presbyterian Joint Public Questions Committees with the 1983 report not only examining social consequences, but also beginning to suggest a theological basis for the intrinsic value of work. ${ }^{159}$ As unemployment continued to increase with the introduction of the Labour Government's economic policy, concerns mounted in the Churches until in 1988 the Presbyterian General Assembly agreed to express its concern to the Government over the direction and speed of Government action in restructuring the economy. ${ }^{160}$ The Joint Public Questions Committee commented in its main report that year: -

The creation of wealth is not an end in itself; it is merely a tool to be used for the benfit of people. Wealth, of itself, is not a positive social value.

Individual freedom and competition on the one hand; equity and social justice on the other hand, are contradictory values. ${ }^{161}$

Presbyterian and Methodist parishes, presbyteries and synods were also challenged by their Assembly and Conference to study and comment on a report entitled

${ }^{158}$ Reports of Committees to the General Assembly of the Presbyterian Church of New Zealand, 1978, p. 289

159 Reports of Committees to the General Assembly of the Presbyterian Church of New Zealand, 1983, pp. 164-66. It must be noted that the brief theological discussion was not of New Zealand origin, but was cited from a report of the British Methodist Church.

160 Presbyterian Church of New Zealand Year Book 1989, and Proceedings of the General Assembly 1988, pp. 260-1

${ }^{161}$ Reports of Committees to the General Assembly of the Presbyterian Church of New Zealand, 1988, p. 206 
Unemployment: the Denial of a Basic Human Right which examined the value of employment from the perspective of the report issued by the Royal Commission on Social Policy released earlier that year, and gave a detailed summary about the effects of unemployment both socially and economically. ${ }^{162}$ Reactions to this study paper indicated that the wider Methodist and Presbyterian churches not only saw the necessity to constantly remind the Government of their concern about unemployment, but also recognised a need to challenge the self-interested materialistic ethic which motivates our society. ${ }^{163}$

In response to a request by the 1988 Methodist Conference a further paper on The Nature of Work was released for comment in 1990 that raised such issues as attitudes to work and paid employment, suggestions for practical steps to prevent the increase of unemployment, attitudes towards the unemployed, the trend for increased "spare time," the need for a definition of work suitable for the late twentieth century, and the future of work. ${ }^{164}$ Despite the relative superficiality of the paper, the submissions received illustrated that Christians in the wider community were concerned about work issues, particularly unemployment. A redefinition of work to include unpaid work was also perceived as important, and the Public Questions Committee suggested the following to fill this need: -

Any activity (mental, physical, social or spiritual) that contributes to an

162 ibid, Appendix to Joint Public Questions Report, pp. 220-227

${ }^{163}$ Reports of Committees, 1989, p. 319

164 Joint Methodist-Presbyterian Public Questions Committee, The Nature of Work, Occasional paper No. 1. 
individual's sense of self-worth and to the well-being of society; it is using one's personal abilities and time to be creative, useful to others, and to enhance one's own life, to glorify God. ${ }^{165}$

While important social justice questions were raised regarding the effect of unemployment, the theology of work presented by the Presbyterian and Methodist Churches was weak or virtually nonexistent, rather confirming comments made earlier regarding the paucity of understanding in the New Zealand churches. ${ }^{166}$ However, in this context it must be acknowledged that elsewhere in the New Zealand church, Richard Randerson produced two slim volumes addressing economic issues within theological and sociological frameworks, supported by the Anglican Diocese of Wellington. ${ }^{167}$ These were to prove valuable resources to the wider church community in New Zealand although it needs to be noted that Randerson's theology, as in most instances in New Zealand, was "borrowed" from American and European writers. The only profound theology to emerge from an actual church body addressing issues of work, unemployment, and the economics undergirding them, came from the Roman Catholic Church, and was likewise dependent on the social teaching of the Church internationally.

One noteworthy Christian response to the unemployment question in New Zealand came from the Industrial Trade and Industry Mission (ITIM) in 1989, with the organisation

165 Reports of Committees, 1991, p. 238

166 See note 147

167 Christian Ethics and the New Zealand Economy, (1987), and Hearts and Minds. A Place for People in a Market Economy, (1992) 
of a national conference for church representatives, trade union and business people, public servants and social workers, to examine possible solutions to the unemployment problem. The ITIM Wellington Director responsible for organising the conference, commented that the Church needed to become more prophetic ${ }^{168}$ on the issue of unemployment. We are too often as Christians criticised for being long on rhetoric and short on action, he commented. ${ }^{169}$ From the conference a "Church Group" was established representing ITIM, Church social services, and parishes, which was to raise the consciousness of the church by linking issues of biblical and theological awareness, social analysis, political awareness and economics in a reflection/action/reflection model. ${ }^{170}$ The group went on meeting after the conference and published a broadsheet prior to the 1990 elections to raise parish understanding of the issues surrounding unemployment. ${ }^{171}$ Once again it has to be said however, that the only theology of work to be presented by the group originated with the Roman Catholic, Cardinal Williams. ${ }^{172}$ The practical ability to address problems of social justice appears more at the forefront of religious experience in contemporary New Zealand than meaningful original theological reflection.

An unexpected consequence of unemployment in western capitalist nations, is that it

168 John Mabon, ITIM, cited in Church's Problem Too, Crosslink, June 1989, Vol. 3 , No. 5 , p. 2

169 Mabon, John, Here to Stay, ITIM Contact, August, 1989, p. 2

${ }^{170}$ Follow up Vital to Success, News ITIMS, 3, September, 1989, p. 3

${ }^{171}$ Horrill, Seton, Forging a Workplace Mission, p. 176

172 Williams, Tom, Structured joblessness a moral "evil", Unemployment, August, 1990 , p. 1 
raises questions theologically about rest and leisure. A distorted view that the available leisure time somehow compensates for unemployment is not uncommon ${ }^{173}$ despite a long held traditional perception of unemployment as equating to laziness. This transformation of unemployment into leisure is due to a set of beliefs related to work and leisure in which work is regarded as compulsive toil, a means to obtain money for consumption outside work. Leisure on the other hand is considered to be the source of satisfaction and pleasure, freedom and creativity, a redress for the misery of work. ${ }^{174}$ Such ideas play into the hands of ideological justifications of unemployment, ignoring that leisure is not sufficient compensation for lack of work. ${ }^{175}$

From a traditional viewpoint, work and leisure occupy different ends of a continuum, ${ }^{176}$ and the suggestion has been made that historically it was easier to monitor and regulate life under a work program than to inspire its constructive use outside work. ${ }^{177}$ The established emphasis on the nobility of work, which helped offset the misuse of time in an industrial context, resulted in a negative outlook on leisure, disregarding the Biblical teaching on rest. Although the Biblical conception is somewhat different from how we discern modern leisure, it is clear from the fourth commandment, (Exodus 20: 8-11),

173 Meeks, p. 136; Clarke, John, \& Critcher, Chas, The Devil Makes Work: Leisure in Capitalist Britain, p. 2

174 Clarke \& Critcher, p. 3

${ }^{175}$ Meeks, p. 136

176 Volf, p. 134

177 Obenhaus, p. 195 
that humans are not supposed to work the whole time. ${ }^{178}$ The human being may be made in God's image but is nevertheless a finite being, and the Sabbath spells a limit to the toil and fatigue of work. ${ }^{179}$ Douglas Meeks comments: -

Without the Sabbath, work will destroy the human being. An economy driven to incessant work by the profit motive is an economy that is driving itself mad. Sabbath is a limit to the presumptions of work. ${ }^{180}$

Leisure or rest, should be understood as a "foil" to work, a time that gives harmony to life and provides it with meaning over and beyond continual work. ${ }^{181}$ Moreover, leisure is spiritual. It is not only about wholeness and becoming more fully human, it is about the temporary freedom from work and the possibility of transcending the everyday world, and allowing God a means of communing with us. ${ }^{182}$

Central to the whole consideration of the theological meaning of work, is the question of the continued relevance in the late twentieth century of the so-called Protestant work ethic. Paul Ballard explains that in this sense an ethic,

is a set of social expectations that act, on the one hand, as an incentive, by providing an aim for members of society. Yet, on the other hand, these expectations provide a criterion by which people can be judged. ${ }^{183}$

${ }^{178}$ Richardson, Alan, (1952), p. 55

179 Meeks, p. 137

${ }^{180}$ ibid, p. 138

181 Ballard, (1982), p. 52

${ }^{182}$ Collins, Chris, p. 3

183 Ballard, (1987), p. 43 
Ideally, as a theory for the conduct of human work, such an ethic raises questions that are life questions encountered by people while working. The individual responds according to the reality that is their experience, a reality that determines who they are and what responsibilities they face regarding their work. ${ }^{184}$ However, this is the ideal, and the actuality of the work ethic in the twentieth century is quite different. From its origins as a theological interpretation of work and vocation, it emerged after the industrial revolution, as little more than an ideology to support the marketplace and its division of labour. By the late twentieth century it was literally being attacked as the dogmas of the glorification of the individual, the suggestion that a person's chief aim is work, and the competitive base for economic theory, ${ }^{185}$ were denounced.

The realisation by theologians that the economic realities experienced by the capitalist West in the last few decades of the twentieth century had destroyed any uniform understanding of the Protestant work ethic, ${ }^{186}$ meant that note needed to be taken of the metamorphosis it had passed through since the Reformation. From its beginnings as $a$ communal ideal, it was increasingly recognised that the Puritan ethic had degenerated slowly into an individualized work ethic, ${ }^{187}$ which contracted even further under the influence of laissez faire ideology and free market policies, into a largely secularised

184 Rendtorff, Trutz, Ethics, Vol. 1, p. 3

185 Davis \& Gosling, p. 83

${ }^{186}$ Raines \& Day-Lower, p. 95

187 ibid, p. 97 
model, designated the success ethic by Douglas Meeks and others. ${ }^{188}$ This success ethic has been the dominant work ethic governing the assumptions of economists, politicians and business people since the 1970s, resulting in the type of economic restructuring witnessed in New Zealand and Great Britain.

Those embracing this distorted version of the Reformers' work ethic, claim to encourage work incentive to the employed and unemployed by convincing them they are in charge of their own economic fate, and that even poverty is no obstacle to success if the worker has a positive belief in work. Benevolence in the form of welfare, it is implied, inhibits individuals from improving themselves through work. The fact that relatively few people are successful is immaterial to those who are, for they genuinely believe that there is a prospect for material success for all who work hard. ${ }^{189}$

From a theological viewpoint, such an ethic is in complete antipathy to the scriptural basis of recent attempts to define a Christian meaning of work, and instead serves to segregate the "haves" and the "have-nots", the employed and the unemployed. This destruction of solidarity between workers results in work becoming a commodity that some possess and some do not. ${ }^{190}$ Unable to distinguish reasons for unemployment

${ }^{188}$ Meeks, p. 142; Rose, p. 87. The writing of Samuel Smiles discussed in Chapter 2 also contributed significantly to this success ethic.

189 ibid. MAF/DSIR GEO staff were asked about their beliefs concerning worldly success in light of the traditional work ethic assumption that success was God's reward for hard work. $67 \%$ of the respondents with a religious affiliation stated that success was not God's reward, with only $8 \%$ indicating that they believed success was due to God's reward. However $13 \%$ were unsure, and another $11 \%$ responded that they thought sometimes success was due to God's reward.

${ }^{190}$ Soelle \& Cloyes, p. 69 
within the economic system because of its inherent belief that the fault lies with the individual, this corrupted version of the work ethic, exercises a tyranny over workers and believers alike, ${ }^{191}$ and assists in their dehumanisation. ${ }^{192}$ Further to this, the emphasis placed by the success ethic on financial compensation for work, undermines the values about work that theology has attempted to reveal - such as creative power and fulfilment, our relationships with other workers, and the transformation of and reconciliation with nature. ${ }^{193}$

While many of those who advocate a work ethic are obviously totally distanced from the idea of work as service to God, surprisingly they frequently still cling to pious attitudes about work, predispositions inherited from a different era. ${ }^{194}$ In The Secular City, Harvey Cox describes work as an example of how residual religious meanings can adhere to an activity despite its essential secularisation. ${ }^{195}$ These religious connotations are often held below the level of consciousness, ${ }^{196}$ but nevertheless influence society's outlook. Interestingly it is the churches and theologians who are rejecting the subliminal religious implications of the contemporary work ethic as being little more than ideological interpretations used to bolster the capitalist system.

191 Johnson, Paul G., Grace: God's Work Ethic, p. 38

192 Soelle \& Cloyes, p. 64

193 ibid, p. 69

194 Cox, Harvey, The Secular City, p. 193. Margaret Thatcher and Brian Griffiths in Great Britain, and Ruth Richardson and Jenny Shipley in New Zealand, would be good examples of this.

195 ibid, p. 191

196 ibid, p. 193 
There is a general agreement among theologians studying work, that the Protestant work ethic as it has evolved, has become profoundly counterproductive in today's social setting. ${ }^{197}$ It has reduced the value and meaning of work, concentrated on consumerism, and demanded the unquestioning obedience of working people. Individual achievement, a moral intolerance for laziness, a certain self-righteousness, and an often insufferable ambition, ${ }^{198}$ have become characteristics of those who embrace its ideology. Achievement, not service, has become the focus. ${ }^{199}$ The prime heresy of the work ethic has been its emphasis on the importance of the occupational at the expense of the informal, the convivial world of family and friends, the spheres of festivity and recreation, the blessedness of unstructured time..$^{200}$

It may be however, that the work ethic only represents the views and expectations of certain key groups within the community, although they may gauge their convictions as belonging to the whole, and therefore being the normative view. ${ }^{201}$ Far from being the consensus of the community, the work ethic may now be only relevant to the middle class professionals who are more marketable in the commercial world, ${ }^{202}$ rather than to

${ }^{197}$ Davis \& Gosling, p. 81

198 Raines \& Day-Lower, p. 97

199 ibid

${ }^{200}$ Clarke, p. 197

201 Ballard, (1987), p. 44

${ }^{202}$ Raines \& Day-Lower, p. 97; Ballard, (1987), p. 43. The work ethic may also still find relevance among some church members, although as Paul G. Johnson points out, there is a tendency to ignore the influence of the work ethic on the religious faith of people. (p. 29) The MAF/DSIR GEO survey demonstrated that $38 \%$ of those with a religious affiliation acknowledged that this made a difference to their attitude to their work. (40\% 
those whose work is not valued as of much worth, ${ }^{203}$ or who are among the unemployed. Acknowledging that the traditional realisation of the work ethic was therefore no longer attainable by a large percentage of the population, ${ }^{204}$ churches and theologians called for a redefining of the work ethic. In New Zealand the call from the Methodist and Presbyterian Churches for comment on whether the Protestant work ethic could be reconciled to present day reality resulted in some interesting responses. ${ }^{205}$ The Baptist Church went as far as to publish an article in its monthly newspaper saying Christian's need to throw out the Protestant work ethic and put work back in perspective, ${ }^{206}$ while the Religious Society of Friends made it clear that they believed the Protestant work ethic was responsible for the injustices of unemployment, and that new attitudes needed to be developed. ${ }^{207}$

Several alternatives to the Protestant work ethic, suggested by British and American theologians, are summarised by Paul Ballard in his book, In and Out of Work: A Pastoral Perspective. The instrumental ethic involves the concept of not only providing for one's survival through work, but broadens into the idea of sustaining family, home and leisure. In other words one's work is instrumental in providing for more than merely

indicated that their religious affiliation made no difference.) Appendix 6 records the explanations given by those who believed their work attitude was affected by their faith.

203 For this reason the MAF/ DSIR GEO survey results can only be relevant for a portion of middle class New Zealanders.

204 Joint Methodist-Presbyterian Public Questions Committee, (1990), p. 1

205 These can be found in Appendix 7.

206 Jobless challenge our attitudes to work, NZ Baptist, October, 1984, pp. 6-7

207 Kappes, C. A., Work Ethic, Accent, Vol. 3, No. 3, April 1988, p. 5 
subsistence. It takes the focus of work out of the workplace into one's personal life. ${ }^{208}$ For some individuals the reward for correct behaviour is fulfilled in and through the personal and private, rather than the structure of work in what has been dubbed the domestic ethic. ${ }^{209}$ Presumably this ethic can be applied those "working" in the home women with young children, house-husbands, homemakers in general, who are not in paid employment, but who gain personal satisfaction and fulfilment from the activities they engage in on a domestic front. Ballard also mentions the concept of the leisure ethic, which is proposed as a direct antithesis to the work ethic in an attempt to give leisure the same importance formerly granted to work..$^{210}$

The two suggestions for alternatives to the work ethic that have gained the most 
The contribution ethic emerged as a response to a growing concern for the defence of the welfare state. ${ }^{213}$ Entailing a belief that humans find fulfilment in serving others, ${ }^{214}$ it not only acknowledges the importance of reciprocity in social groupings, and but also concedes that the work done in the community on a voluntary basis is just as meaningful as that in paid occupations. ${ }^{215}$ Work is still regarded as highly significant but the new ethic also affirms all the other aspects of life and community, and allows for the unemployed to still have useful roles in society. In fact, it is this strong affirmation of the sacred nature of all that lies beyond work, as well as work itself, which is the distinctive feature of this whole life, or Contribution Ethic. ${ }^{216}$

As theologians have examined the meaning of work, and the place of the Protestant work ethic within that meaning, it has emerged, along with the rediscovery of a profound spiritual meaning for human work, that a new ethic is necessary for both Christians and nonbelievers. The old ethic has been too distorted and desecrated by its deterioration into little more than an ideology to be of relevance in the contemporary world of mass unemployment. The challenge facing theologians is to find a work ethic that reintegrates human work with the rhythm of creation, and recovers the importance of the human community in relationship to work and leisure.

${ }^{213}$ Ballard, (1987), p. 63

${ }^{214}$ Clarke, p. 196

215 ibid, p. 197

216 ibid 


\section{CHAPTER 9}

The Work Ethic in New Zealand - Fact or Fiction?

\section{A Conclusion.}

Keeping in mind Max Weber's attempt to understand the culture he lived in through exploring the perspectives of the past and the present, ${ }^{1}$ this examination of the work ethic in New Zealand has taken snap shot ${ }^{2}$ studies of three generations of New Zealanders. Beginning in the sepia of Victorian pioneer New Zealand, moving to the harshness of a black and white New Zealand in the Great Depression of the 1930s, and concluding with a panoramic shot of the recent history of change in the decades of the 70 s to the $90 \mathrm{~s}$. Associations and correlations have been made which suggest that in two groups at least, the politicians and the professional middle class, the ideology of the work ethic has been an axiom by which New Zealanders have lived, whether it be consciously or instinctively.

In line with the methodology of liberation theology, an examination of the changing ideology of work 1984-1992, from a social science and theological perspective, accompanys the socio-historico review, and helps to endorse the continuing belief in the concept of the work ethic. It also provides a base for measuring the work ethic of the group of New Zealand public servants surveyed concerning the effect of their changing work environment on their attitudes to work. The results of the survey demonstrated that

\footnotetext{
${ }^{1}$ Fischoff, p. 61

2 Wagner, p. 37
} 
there is still a strong to moderate commitment to concepts surrounding the work ethic among this group of individuals, albeit unconsciously in many instances.

Given a definition of work ethic that entails a belief in industriousness as an ideal, frugality as a virtue, and idleness and waste as vices, and which encourages ambition and success while condemning complacency and failure, the historical survey suggests that while such an ideology was transported from Victorian Great Britain in the nineteenth century colony, it has remained entrenched in the mores of New Zealand society and culture throughout the last one hundred and fifty years. The nineteenth century settlers carried with them a middle class puritan work ethic which assured them opportunity and prosperity, provided industriousness, thrift and perseverance were their prime motivators, and from an equally early date, New Zealand's political figures promoted these attributes of the work ethic as the ideal characteristics for those immigrating to the colony. Neither the accessibility nor the unavailability of employment, were considered as factors in the encouragement of the virtues of the work ethic by the nations' early leaders, and this oversight was to persist throughout New Zealand's history.

While theological comment in New Zealand during the nineteenth century on the issue of the value of work is sparse, it appears that the mainline Protestant denominations, especially the Presbyterian and Anglican churches, encouraged the evangelical gospel of work of their mother churches in Great Britain. Nevertheless, it is noted that there was some consternation among individual churchmen regarding the focus on the acquisition of wealth, and also concern expressed over the economic straits in which some settlers found themselves, despite their efforts to embrace the sanctioned work values of society 
and the church.

The Victorian work ethic of settler New Zealand was still instinctively recognised and conformed to, by the majority of the population at the time of the Great Depression of the 1930s. Having not long emerged from the influence of Victorian ideals and attitudes, the world view of the people and politicians of the period encompassed a belief in the value of hard work and the unworthiness of idleness. Unemployment was regarded by many as personal failure, not the fault of the economic system, hence the sanction given to relief camps and the adage of " no pay without work" by the general population. The politicians were more interested in balancing the books than examining the irrelevant economic rules that had led to the depression, and it was some time before there was any recognition that unemployment was not necessarily the fault of the individual.

It is significant that undergirding the attitudes of many of the politicians of the 1930 s was a Presbyterian heritage which appears to have supported their collective conviction that unemployment indicated personal failing. It is equally significant that as the $1930 \mathrm{~s}$ progressed, the churches, including the Presbyterian church, rather than championing the government's policies, adopted a social gospel that while providing charitable aid, also criticised the strategies of the politicians. Recognition that it was economic systems which were failing, rather than individuals, led to calls for social justice and reviews of economic structures from both Protestant and Roman Catholic spokespeople, but the long declared virtues of hard work, perseverance and thrift were seemingly never examined. In reality the ideology of the work ethic remained intact even within the churches. 
By the final period to be examined in the socio-historico review of work in New Zealand, 1984-1992, the Victorian influence was long gone in relative terms, and a new understanding of work was materialising out of the philosophy of social sciences. While, according to Ruth Richardson, the work ethic in New Zealand had been diminished to such an extent by this time that she could describe it as being a decades-old poor...work ethic ${ }^{3}$, and legislation was optimistically enacted to surreptitiously encourage the return to a work productivity imbued with the Victorian attributes of the nineteenth century work ethic, the evidence shows that once again it was not individuals who were failing, but the economic system. The attributes of the work ethic described earlier in Victorian terms may not have rung true to the late twentieth century ear relatively unused to hearing the virtues of hard work and frugality, and the vice of idleness proclaimed, but the broader concepts encompassed in the evolving political ideology surrounding work in the 1980 s and early $90 \mathrm{~s}$, would not be unfamiliar. For example, qualities that middle class society at least would recognise as fitting in regards to work attitudes, would include, (1) the expectation that workers should be highly productive, achievement oriented, and take pride in their work; (2) the demand that they should be dependable and show loyalty to their employers or profession; (3) the philosophy which anticipates long hours at work with little time for leisure and recreation, and, (4) the desirability of the acquirement of wealth through hard work and wise investment. ${ }^{4}$

Seemingly overlooked by Ruth Richardson and her parliamentary colleagues, was the

\footnotetext{
${ }^{3}$ Richardson, Ruth, State of the Nation Address, 3 April, 1991

${ }^{4}$ Furnham, (1990), p. 13, citing D. Cherrington
} 
fact that it was not a work ethic that was lacking in the general population, but opportunities for employment. ${ }^{5}$ The survey conducted in the Ministry of Agriculture and Fisheries, and the Department of Scientific and Industrial Research's Geology and Geophysics Division, partly to try and test Richardson's claims, showed that even in the midst of the turmoil of change occurring in New Zealand society, as represented in this instance by the public service restructuring, there was a moderate to strong work ethic still existing in the middle class. ${ }^{6}$ In keeping with 1991 census figures, ${ }^{7}$ nearly half those surveyed worked over forty hours a week. Admittedly $75 \%$ of those working over forty hours a week in the public service would have preferred not to do so, but nevertheless they did so because they liked to get the job finished. ${ }^{8}$ While a majority of these public servants indicated that personal fulfilment and satisfaction rated slightly ahead of money as reasons for working, closely followed by self-esteem, security and a sense of

${ }^{5}$ Unemployment figures in themselves offer evidence that work was hard to find in 1991, $(163,770)$. Even some of the middle class public was not amused by comments from advocates of the work ethic as shown in the following letter from Moyra Pearce of Wellington, to the editor of the Evening Post, 1/9/91.

When your columnist Alan Duff claims "some of us are a funny lot" he must be one of the funniest in my experience. He laments that the work ethic is not being advocated by educationalists. What work? There isn't any. Unless he is referring to another planet. As an affluent middle class New Zealander, I encourage my own children in this work ethic but daily ask myself why. What choices will they really have, even if they can afford university study? They are more likely to be part of the "surplus labour market," the jargon of the new economic right for "unemployed", which is essential for their monetarist policies to work.

6 See Tables 8 and 9. As the working classes were more likely to be affected by unemployment it is possible that their work ethic (assuming it existed) may have diminished as a consequence.

7 Census figures showed that one half of all workers worked over 43 hours per week, and many worked over 50 hours. ( Population Overview, 1991 Census, p. 42-43)

${ }^{8}$ See Chapter 7 
meaningfulness, ${ }^{9}$ this is an indication of the changing motivations for work typical of the post- $1960 \mathrm{~s},{ }^{10}$ and is not to be seen in any way as evidence of a decrease in work ethic. Instead it is an indication that middle class professionals were seeking to understand their work habits in new ways. With employment increasingly hard to find, and redundancy situations rife, it was essential that workers reflect on the meaning of work.

The public service survey, limited though it was to two specific departments, largely staffed by educated professionals, indicated that a work ethic ideology had continued to survive in New Zealand society. That a significant proportion of those surveyed had a strong to moderate work ethic strongly suggests that, just as in the 1930 s, the politicians in the late 1980s-early $90 \mathrm{~s}$, were demonstrating a refusal to acknowledge the inadequacies of the economic system so fervently advocated. The call in the early 90 s for an increased work ethic among the wider population was in part, I suggest, a response to the failure of the free market economy to deliver the prosperity anticipated by the right wing politicians of both the Labour and National parties, which in turn appeared to result in a vehement belief that the inadequacy of the policies must somehow be the fault of the workers.

Ignored were the conclusions of the Royal Commission on Social Policy which had reported in 1988 that it was convinced from the submissions it had received, that New Zealanders are in no doubt about the centrality of work to their social and economic

${ }^{9}$ See Table 5

${ }^{10}$ Rose, p. 145, for example mentions the changing values of the "post-bourgeois" society of the late twentieth century. 
well-being. ${ }^{11}$ Instead, what Miles Fairburn has described as Victorian settler notions for 'getting on', were accentuated by politicians emphasising enterprise and innovation, ${ }^{12}$ and promoting the traditional ideology that rewards should be proportionate to effort, that acquisition should be an individualistic activity. ${ }^{13}$

However, as one sector of New Zealand society was proclaiming its belief in a work ethic which was expected to lead the nation to renewed prosperity, others were questioning the very validity of the whole ideology of the work ethic for late twentieth century New Zealand. The existence of a work ethic in New Zealand from colonial to contemporary times, does not appear to have ever been seriously doubted by those who were challenging its relevance for the $1980 \mathrm{~s}$ and $90 \mathrm{~s}$, but its continued appropriateness, in light of the deficiency of the traditional economic systems and the contemporary investigations into the meaning of work, was certainly queried as shown in the examination of the theological response to the changing economic situation 1984-92.

It is significant that the Protestant churches, supposedly the birth place of the work ethic, were among the most specific critics, although it has to be acknowledged that much of

${ }^{11}$ Royal Commission on Social Policy, Future Directions, Vol. II, p. 477

12 Fairburn, Miles, (1989), p. 268

${ }^{13} \mathrm{ibid}$. If one could adequately describe the work ethic ideology proclaimed by the New Zealand politicians of the late twentieth century in the form of a mathematical equation it would probably look like this:

work ethic $=$ individual effort + motivation $=$ achievement, success, wealth $=$ happiness (One of the respondents to the 1991 survey described the work ethic as the ratio of quality of work completed or undertaken to the reward received; the ratio of quality of work performed to reward received. ) 
their debate about the work ethic went largely unnoticed, ${ }^{14}$ probably because numerically they were no longer a force to be taken seriously. The public focus of the churches on the injustice of unemployment on the other hand, which had been well documented in the Great Depression, was similarly expressed in the late 1980 s and early 90 s, and the emphasis on social praxis took the forefront in most church discussions.

This encouragement of social protest and community action in regards to issues surrounding unemployment was evidently deemed as more important by the churches than serious theological reflection on the meaning and nature of work in a New Zealand context. What little theological reflection had transpired during the 1930 s, was predisposed to echoing the spirituality surrounding the Victorian work ethic of the eighteenth and nineteenth centuries. Theological deliberation in the 1980s and early 1990 s tended to be heavily influenced by overseas writers, and so while the ongoing appropriateness of the traditional work ethic was challenged, no indigenous theological alternatives were mooted.

Employed, middle class, Christian New Zealanders were sometimes told by their churches in the 1980 s -90 s that they needed to look carefully at their addiction to the work ethic, ${ }^{15}$

${ }^{14}$ As pointed out in the previous chapter it was the Roman Catholic Church which was the most vocal about the evil of unemployment, and the Catholic church's social teaching about the value of work was well recognised. The work ethic itself does not seem to have been an issue for the Catholic church however.

${ }^{15}$ Roberts, Campbell, Employment in the Future, Howick All Saints Anglican Church Magazine, Lent, 1986 
and that the work ethic was no longer sustainable, ${ }^{16}$ but frequently no options were offered aside from practical suggestions for helping those who were unemployed through training schemes, shorter working weeks, and job sharing. ${ }^{17}$ Given that even regular church attenders in New Zealand were not generally exposed to the contemporary theologies of work originating off shore, it seems unlikely that many of them gave serious consideration to finding an alternative to the long distorted ideology behind the newly politicised work ethic.

The public servants who contributed through their responses, a glimpse of the professional middle class work ethic of the early 1990 s, also provided a limited view of the influence of religious affiliation on attitudes towards work, although of the $52 \%$ who acknowledged some church affiliation, clearly few had given any critical deliberation to the connection between their faith and their work. In fact, of those with a recognised religious affiliation, $40 \%$ claimed that this made no difference as to how they viewed their work, and among those who did see some connection, a theological understanding of work appears to have been limited. Many of the statements made by respondents regarding the effect of religious affiliation on their attitude towards work in reality could equally have been made by those with no affiliation. ${ }^{18}$ What few statements were made with any theological content tended to echo traditional fundamentals such as work is a blessing and is meant

16 ibid

17 ibid. The Joint Methodist-Presbyterian Public Questions Committee discussion paper on The Nature of Work also made similar suggestions.

18 For example, statements referring to tolerance of work mates, principles of honesty and responsibility, could be made by anyone. (See Appendix 6) 
to serve God. ${ }^{19}$ Very few statements reflected any understanding of a contemporary theological understanding of work although the concept of work as co-creation was alluded to by an extremely limited number of the survey respondents, indicating that some church members were more aware than others of current thought.

Among the definitions given by the survey respondents for the meaning of the term work ethic however, were several statements that demonstrated that some definitely understood the traditional concept of the Protestant work ethic, with definitions such as Work is good, and good work leads to success, fulfilment and God's blessings; and work is good and idleness is evil, and... those who work hard will be rewarded. ${ }^{20}$ Others recognised work as a principle or moral imperative which made a valuable contribution to society. A considerable number of the definitions given could be identified as indirectly, and possibly unknowingly, showing theological overtones which implies that religious affiliation is not a necessary component in the acceptance of the ideology of work as encompassed by the notion of the Protestant work ethic. ${ }^{21}$ This is reinforced by the fact that there was only a marginal difference between those with a religious affiliation who saw hard work as good as compared to those who had no religious connections.

19 ibid

20 See Appendix 4

${ }^{21}$ It needs to be recognised however, that some of the more theological statements made as definitions of the work ethic may possibly have been given by those with some religious affiliation. Unfortunately the connection between the definitions and respondents with religious affiliation was not sought. Nevertheless statistics showed that religious affiliation made little difference as to whether respondents had heard of the work ethic. 
Although outside the tenets of the traditional concept of the work ethic, the idea of the workplace as an opportunity to evangelize was claimed by several of the 1991 survey respondents who acknowledged a Pentecostal affiliation. ${ }^{22}$ To what extent this evangelization included the urging of hard work, and the assertion of its accompanying reward of God's blessing through success, is unknown, but it seems that within some of the conservative dissenting churches the work ethic was actually reawakened by the monetarist policies of the Labour and National governments, and business success once again hailed as a proof of virtue. ${ }^{23}$

The extent of this "reawakening" of the work ethic ideology through political measures among the general population, however, is debatable. The politicians may have seen it as a necessary concept to help revive a flagging economy, but considering that it was the mistaken assertion that New Zealanders had a decades-old poor work ethic that led to this conviction, the magnitude of any possible revitalisation of the work ethic must be questioned. The tendency for New Zealanders to demonstrate an extrinsic motivation to work, whereby they met many of their personal needs for fulfilment and satisfaction outside the workplace, ${ }^{24}$ seems to have been prevalent during the years of full employment when the welfare state was at its height, but does not necessarily indicate a poor work ethic that needed to be stimulated into activity.

\footnotetext{
${ }^{22}$ See Appendix 6
}

23 Eldred-Griggs, (1990), p. 197. I have been told that meetings of the Full Gospel Businessmen's Fellowship frequently glorified the values of the work ethic, especially the concept of success equating with God's reward. However this is only anecdotal and I have no concrete evidence that this was so.

${ }^{24}$ Nedd \& Marsh, p. 1. Also refer to Chapter 7 for further discussion regarding the socalled poor work ethic of the $50 \mathrm{~s}$ and $60 \mathrm{~s}$. 
In fact it is ironic that the one era in New Zealand history in which it appears that there was a decline in the work ethic was the years of full employment and the welfare state, that is, the post World War II years through to the early 70 s at which time the economy began to seriously deteriorate and unemployment to raise its head. The comments of observers during this period, as shown earlier, ${ }^{25}$ reveal an impression of a country in which work as employment was secondary to work around the home. But even in the midst of critiques about the work ethic of New Zealanders there was the occasional writer who still saw New Zealand as a work-oriented society, ${ }^{26}$ and who, instead of blaming the welfare state for the decline in work habits as was the norm, actually claimed that the social security system helped coerce people into maintaining some form of employment, ${ }^{27}$ and encouraged them to make provision through savings, against the possibility of unemployment. ${ }^{28}$

The very welfare system that had been instituted initially to protect those unable to find employment and to provide them with some measure of financial security, however meagre, incurred much of the blame in the late 1980s-early 90 s neverthelss, for having reduced the need for an active work ethic. Instead of examining what were essentially the failures of an economic strategy, politicians placed the onus for a lack of productivity on the welfare system. The recipients of welfare assistance in turn, were ascribed with having

${ }^{25}$ See Chapter 7

26 Jones, P. E. R., The Need for Manpower Planning, in Thomson, K. W., \& Trlin, A. D., (eds), Contemporary New Zealand, p. 72

27 ibid. Jones observed that benefits were so small that people preferred to work than struggle to survive on them.

28 ibid 
a poor work ethic, thus reverting to a Victorian mind set which blamed individuals for what was primarily a fault in the economic system.

It is incongruous that this belief in an apparent weakening of the work ethic was generally attributed to the welfare system that, in New Zealand at least, had been maintained by full employment. Roger Douglas, in a book published after he had left politics, places the blame firmly on past New Zealand governments and the welfare system.

The state has taken responsibility for so many things in life - that our personal values have decayed as a result. Governments have put in place policies that have created a sort of poverty that will never be cured by economic growth. Governments have paid young men to be idle and through a corrupting social welfare system have destroyed the work ethic and the sense of personal responsibility that is the source of people's dignity. ${ }^{29}$

The paradox of the welfare system and its impact on the work ethic is the fact that the recipients of welfare benefits were expected to live by what can be described as work ethic attributes, despite the meagreness of benefits, and were encouraged to not build up debts, use credit carefully, budget and plan ahead, be prompt for appointments, avoid alcohol, indulge in non-conspicuous consumption. ${ }^{30}$

By the 1980s the welfare system which had been part of the brave new world of modern social democracy was under attack by the brave old world of nineteenth century

${ }^{29}$ Douglas, Roger, (1996), Completing the Circle, p. 7

${ }^{30}$ Furnham, (1990), p. 177. While Furnham is in this instance referring to the welfare system in the United States I believe that New Zealand has had the same expectations of welfare beneficiaries. 
capitalism, ${ }^{31}$ not only in New Zealand but also other western countries. The ideology of the work ethic, instead of just being used to subtly intimidate beneficiaries, was overtly resurrected by politicians throughout the capitalist world. Values regarded as the original Protestant work ethic values, like hard work, ambitiousness and self-reliance, were publicly revived. ${ }^{32}$ In Britain, Thatcher and others were promoting a restoration of the Victorian values of thrift, industriousness, discipline and responsibility, with the apparent belief that the rewards would be a return to prosperity. ${ }^{33}$ In the United States, the welfare system was increasingly condemned as being responsible for an evaporation of the work ethic, ${ }^{34}$ and work fare programmes ${ }^{35}$ were advocated by President Reagan and his supporters to generate a work ethic culture to fight poverty. ${ }^{36}$

The new moralistic attitude towards social welfare that emerged in many western countries during these years was in reality not so new, but reverted in essence to the Victorian conviction of the "deserving" and "undeserving" poor. Benefits were reduced to those seen as undeserving, and the poor were again forced to work for their sustenance. $^{37}$ The belief that generous benefits discouraged work effort became the norm,

31 Eldred-Griggs, (1990), p. 237

${ }^{32}$ Furnham, (1990), p. 178

${ }^{33}$ Ballard, (1987), pp. 60-1

${ }^{34}$ Kaus, Mickey, The Work Ethic State, The New Republic, July 7, 1986, p. 22, states the case for the United States

35 ibid, p. 25

36 ibid, p. 33

37 Jones, Michael, p. 23 
and the political solution was to stimulate the movement from welfare to work. ${ }^{38}$

In New Zealand, the government inevitably emulated its international counterparts promoting the economic and philosophical principle that work must receive a different reward from non-work, and that non-workers should not be entitled to the same experiences and quality of life as workers. ${ }^{39}$ From the generosity of the earlier universal welfare system, the National Government moved, in the early 1990 s, to provide no more than an austere minimal safety $n e t^{40}$ for those in need, as a further component in the revolutionary economic restructuring of the country begun by the Fourth Labour Government in 1984. The welfare system, established largely in response to the Great Depression, was gradually dismantled and pared to its absolute limits.

The belief of Roger Douglas, Ruth Richardson and many of their colleagues, that success and financial prosperity would return to New Zealand if the economy was restructured in terms of free market policies, and people were encouraged to raise their levels of commitment to work, was in reality a return to the nineteenth century driving forces behind industrial development in Britain, and settler accomplishments in New Zealand . The ultimate goal was wealth - wealth as a nation and for individuals. ${ }^{41}$ Of this aspiration to wealth it has been said,

When one looks at the situation from the very historical perspective which

\footnotetext{
${ }^{38}$ McClure, p. 247

39 ibid, p. 234

${ }^{40}$ Jones, Michael, p. 73

${ }^{41}$ Vanderkloet, Edward, Why Work Anyway? in Marshall et al, p. 31
} 
ostensibly gave rise to it, explanations in terms of the Protestant Ethic emerge as little more than an invention of twentieth-century social science, with unwarranted pretensions to an ancient lineage. The "ethic" which has been truly predominant and pervasive is not a work ethic but, for want of a better term, a wealth ethic...The "ethic" is to make or to have sufficient wealth not to have to depend on others; work is only one means to that end, and certainly not the only one universally esteemed. ${ }^{42}$

The wealth ethic, plus the success ethic described in the last chapter, appear to go hand in hand, and can be seen as outcomes of the work ethic, in as much as they are the primary objectives of many who have claimed to embrace the work ethic. It seems likely that in subscribing to the work ethic, twentieth century politicians are in actuality attesting to a work behaviour emerging from competitive economies in which achievement, recognition and success are basic principles. ${ }^{43}$ However, in light of the 1991 public service survey, it needs to be noted that while money was a vitally important reason for working for the respondents, ${ }^{44}$ it was not the prime motivator, which brings into doubt the accuracy of the politicians' understanding that personal status and materialistic success are the chief motivators behind the work ethic.

Metaphysical influences however, are either seen as insignificant, or non-existent, by politicians in a secular society such as New Zealand, ${ }^{45}$ and Roger Douglas's reflections after his resignation from parliament, appear to bear this out. Hard work, he writes, very

${ }^{42}$ Kelvin, P. \& Jarrett, S., cited in Furnham (1990), p. 215

43 Furnham, (1990), p. 48. This type of behaviour has been classified by psychologists as "Type A behaviour". The suggestion has been made that the antecedents of such behaviour are to be found in a godless Protestant work ethic combined with few guiding moral principles.(Furnham citing V. Price, p. 49)

${ }^{44}$ See Table 5 for details of motivation professed by MAF and DSIR staff.

${ }^{45}$ Raines \& Day-Lower, p. 97 
often does lead to success. Thrift does lead to wealth - or something like it. ${ }^{46} \mathrm{He}$ decries the fact that these ideals or values are no longer taught, ${ }^{47}$ and goes on to comment that, hard work should be encouraged because without you achieve nothing. ${ }^{48}$ No where in his writing does Douglas reflect on the origin of the ideals he is espousing, but then he is not alone among his ex-colleagues, who while encouraging a return to the work ethic, also never contemplate the derivation of the paradigm they are advocating.

In calling, either overtly or surreptitiously, for a return to the assumed values of another era, the politicians of the late twentieth century are appealing to the traditional dependability inherent in those values. This, it has been pointed out, can serve a double purpose.

On the one hand it offers a promise to halt and reverse socio-cultural changes that have diversified values and created a substantial degree of anomie; on the other, it backs up an undertaking to solve the economic problem itself, since the latter is portrayed largely as the product of the disorderly work behaviour of employees. $^{49}$

In the New Zealand context this conjecture is particularly relevant to the 1984-92 period, as change assaulted the mind set of the people, and undermined the key elements of European New Zealand's long fostered national identity. ${ }^{50}$ As society became

${ }^{46}$ Douglas, (1996), p. 13

47 ibid

48 ibid, p. 15

${ }^{49}$ Rose, p. 129. Rose goes on to observe that unemployment rates are interpreted in part, as being due to moral failure, which can be corrected by reverting to values found reliable in the past.

${ }^{50}$ Britton, et al, p. 272 
increasingly uncertain and disturbed about the social and economic changes, and began to question the relevance of purely economic theories about work, ${ }^{51}$ the call to a commitment to a work ethic of which many had no understanding, ${ }^{52}$ meant little more than pure rhetoric by politicians embellishing and defending their economic strategies.

The remarkable aspect of this political stratagem is that it is found reflected in various ways throughout the whole of New Zealand's brief history, from the settler period to the late twentieth century. The acknowledgment however, needs to be made that alongside this political approach encouraging a work ethic ideology, was the continuing existence among workers as well, of an ideology attached to notions of industriousness leading to wealth and success. Although the original research component of this thesis involved professional middle class individuals, it has to be recognised that other research has demonstrated that the characteristics of a work ethic have also been ascribed to working class people. Stevan Eldred-Griggs in his study on working people in New Zealand, asserts that they too aimed at making it through hard work, ${ }^{53}$ and the fact that the majority did not rise above their working class status was not for lack of trying. ${ }^{54}$ Desire for mobility up the social ladder was just as real in the late twentieth century as it had been in Victorian settler days, and it is interesting to note that the young people who managed to find promotion from the working class to the middle class thanks to the welfare system

\footnotetext{
51 Anthony, p. 9

${ }^{52}$ The 1991 MAF/DSIR GEO survey indicated that $40 \%$ of those responding had never heard of the work ethic
}

${ }^{53}$ Eldred-Griggs, (1990), p. 169

${ }^{54}$ ibid, p. 175 
and free tertiary education, became the power base of the Labour Party in the $1980 \mathrm{~s}^{55}$ Eldred-Griggs comments: -

The 'free love' middle class of the 1960s became the 'free market' middle class of the 1980s, its sentimental rejection of the welfare state turning into a hard edged celebration of the right of everybody to be rich. ${ }^{56}$

Success stories, like that of Robert Jones, one of New Zealand's richest men at the end of the 1980 s, who had moved from state house to real estate king, ${ }^{57}$ virtually became part of the folk lore of former working class people anxious to maintain their position on the ladder to wealth and success. The revolution in economic restructuring was welcomed by such individuals, largely based on their commitment to an ethic of wealth that justified the widening gap between rich and poor by declaring a faith in values that were related to an ideology centuries old.

It is possible that had Max Weber been writing in the late twentieth century he would have found numerous contemporary examples in New Zealand, of individuals aiming at attaining economic achievement through industriousness, and perseverance. His difficulty would have been in determining the motivation behind this drive for wealth and success, for the fall off in church attendance in New Zealand over the last two generations does not point to a strong religious endorsement of a work ideology implicated in either political strategies, in the work ethic of middle class professionals, or in the aspirations of working class people.

${ }^{55}$ ibid, p. 208

${ }^{56}$ ibid, p. 209

${ }^{57}$ ibid, p. 169 
However, while religion may have had little input into the ongoing work ethic of many New Zealanders once they settled in the new colony, the historical "snap shots" have presented a picture of a nation where the work ideology has consistently reflected many of the images expected from classical illustrations of the Puritan work ethic, as presented in Weber's theory. In a study of New Zealand values conducted by Massey sociologists, Webster and Perry in the late 1980 s, it appeared that religious affiliation and higher attendance levels at church did still have some bearing on work satisfaction, ${ }^{58}$ a result which they believe, is consistent with the view that historically, religion has provided impetus and attitudes necessary to achievement through work. ${ }^{59}$

The work ethic in New Zealand appears to primarily have had a secular base, originating from an industrial, nineteenth century Britain where success and wealth ethics were the driving forces behind hard work, thrift and perseverance. In recent times the term Protestant work ethic has been used very loosely by individuals who have little appreciation for its philosophical or historical basis, to describe the work attributes handed down by our forebears, but it has to be conceded, despite the lack of academic

${ }^{58}$ In Webster, Alan C., \& Perry, Paul E., Values and Beliefs in New Zealand. The Final Report, p. xviii, it was noted that there was some increase in the work ethic of highly religious New Zealanders between 1985 and 1989, although this was not a significant expansion. The extent to which government policies indirectly contributed to this result among regular church goers, can only be conjectured.

59 ibid, p. 52. In their earlier study of 1985, published as The Religious Factor in New Zealand Society, Webster and Perry had stated that the slight association of religiosity with a work ethic is at most a reflection of a more general ordering of individual lives within which a complex pattern of life-chances and life-choices tends to shape working attitudes and in some cases a religious upbringing. There is no basis... for a strong theory of the religious determination of work attitudes. (p. 102) The 1991 survey of MAF and DSIR GEO staff showed that only $38 \%$ of those acknowledging religious affiliation believed that their beliefs affected their work attitudes. 
understanding, that the tenets of the work ethic have been so deeply ingrained in the subconscious of many individuals that they have lingered on through the generations. ${ }^{60}$ The religious foundation of the work ethic may now be an insubstantial abstraction, but the ideology that has emerged from it is still residual in the community, even among those with no church connections. This inherited ideology appears to have been accepted, at least by the middle class professionals and politicians, as the norm.

In conclusion, the socio-historical case studies ("snap shots"), and the examination of the response of New Zealand churches to sometimes difficult issues surrounding an inherited Victorian work ideology, show that there has historically been an active work ethic in New Zealand. The responses of the public servants surveyed in late 1991 also reinforce a belief in the continued existence of this work ethic, secularised though it may be.

Nevertheless, while Ruth Richardson was mistaken in her allegation that New Zealanders have a poor work ethic, it must be observed that the restructuring of economic structures in the period 1984-92, undoubtedly led to a re-intensification of work effort for those in employment. ${ }^{61}$ The question for the future is whether the encouragement and perpetuation of a work ethic based on Victorian ideals, is valid or relevant in a society where unemployment is increasingly an accepted part of the economic system.

60 A small portion of the public servants who responded to the 1991 survey recognised this and commented:-

- The Calvinistic work ethic... was ingrained in me from an early age.

- Programmed upbringing during childhood to young adulthood is difficult to forget in later adulthood - it becomes a hidden baseline for ethical and social behaviour

- Convent trained. Parents with very definite Protestant work ethic.

(See Appendix 6)

${ }^{61}$ See footnote 176 , Chapter 7 


\section{APPENDIX 1}

\section{New Zealand}

Her youth is made heir of the ages,

Her children are freemen and peers,

Plain workers, yet sure of the wages

Slowly destiny pays with the years;

Though little and latest their nation

Yet this they have won without sword

That woman with man shall have station,

The toiler be lord.

William Pember Reeves

from The Long White Cloud

(no page number) 


\section{APPENDIX 2 \\ The Methodology of the 1991 MAF and DSIR (GEO) Survey}

The aim of the survey was to try and ascertain the effect of the changing public service workplace on the work ethic of the staff of MAF and DSIR (GEO) in light of various comments made by politicians in the media about the poor work ethic of New Zealanders. Although the sample being used was largely white, middle class, and professional, it was felt that some indication of the existence of a work ethic in New Zealand could be measured through the responses of this particular group. The corporate management in MAF, which was providing the funding for the research and the survey, was interested in the results from a human resource aspect although the survey results were to be ultimately used in this thesis. ${ }^{1}$

The survey was constructed with the help of Liz Viggers, MAF Qual's Applied Statistics Group's, Senior Statistician. A pilot questionnaire was distributed in September 1991 to twenty MAF staff members who had agreed to assist in the formation of the final questionnaire. The revised version, to be found at the end of this methodological statement, was sent to 500 randomly computer selected staff ${ }^{2}$ in MAF in November, 1991, and to all 220 staff of GEO. Although individuals were asked to return a response

${ }^{1}$ DSIR (GEO) management requested an involvement in the survey which MAF agreed to on the basis of an interest in a comparison of the reaction of staff in the two different departments. GEO financially supported the issue of the survey to its staff and encouraged their participation.

${ }^{2}$ A programme was used to randomly select 500 staff from the 4,166 names appearing on MAF's Personnel Information and Pay-roll System. This task was done by Clive Reynolds of MAF Corp 
slip under separate cover from the questionnaire, to indicate whether or not they had responded, the return rate of the survey was such that I did not follow up with reminders to those who chose not to respond. ${ }^{3}$

Computer data entry of the responses was carried out by several staff in MAF's Head Office Information Services Section, supervised by Mrs Agnes Cox. Once entered the results were computer generated by a MAF Tech Head Office statistician, ${ }^{4}$ after considerable discussion with me regarding the format I required, and about which questions should be correlated. I calculated final percentage outcomes myself.

At the time of the survey, both MAF and DSIR were gearing themselves for the establishment of the Crown Research Institutes in July 1992, and it was unfortunate that GEO announced an early round of redundancies just as the survey was sent out. ${ }^{5}$ The mood of both organisations was mercurial and could have resulted in a low response to the questionnaire but $61 \%$ of the MAF staff, and $57 \%$ of the DSIR staff saw fit to take the time to reply. Some verbally said that they found the answering of the questionnaire therapeutic; others that the questionnaire made them stop and reflect on just what their

${ }^{3}$ There were a number of surveys returned after the closing date, some of which arrived in time to be included in the final results, although there was a small number which arrived too late to be used.

4 This staff member was working for MAF Tech as a temporary worker in 1992, and unfortunately her name was not noted. Attempts to find her name have been unsuccessful.

5 This resulted in some anger from staff out of the Lower Hutt "head office" region, who felt the timing of the survey had been deliberately arranged to coincide with the announcement of the redundancies. Apologies were published in the staff newsletter, both from myself and management, assuring staff that the timing had not been premeditated. The response rate of $57 \%$ may have suffered as a result of the timing but when compared with the $61 \%$ response rate from MAF it seems unlikely. 
work meant to them in the midst of all the changes around them.

(A copy of the questionnaire follows. There are no page numbers as I do not have a copy of the questionnaire on computer disc.) 


\section{A. PERSONALDETAIIS}

1.

$$
\text { Age } \begin{aligned}
& \multicolumn{1}{c}{-25} \\
& 26-35 \\
& 36-45 \\
& 46-55 \\
& 56-
\end{aligned}
$$

2. Gender Male

Female

3. What do you consider your main ethnic origin?

$$
\begin{aligned}
& \text { Maori } \\
& \text { Pacific Islander } \\
& \text { European New Zealander } \\
& \text { Other (please state) } \\
& \text { Prefer not to say }
\end{aligned}
$$

4. Which of the following descriptions best fits your work? (Tick one only)

Manager/Policy maker

Management Support

(eg finance, secretarial,

computing, journalism, personnel)

Consultant

Technical (eg scientists, vets)

Inspector

General support (eg driving, hotel)

Other (please specify)

5. What organisation do you work for?

$$
\begin{aligned}
& \text { MAF } \\
& \text { DSIR } \\
& \text { Other (Please specify) }
\end{aligned}
$$

6. Where do you work?

(Tick as appropriate)

Upper North Island

Lower North Island

Upper South Island

Lower South Island

Town

City

Rural 
7. How many years have you worked for the organisation? Less than one year

1-3 years

4-6 years

7-10 years

$11-15$ years

$16-20$ years

Over 20 years 


\section{B. WORK ETHIC}

8. a) Before reading the introduction to this questionnaire had you heard of the "work ethic"?

Yes

No

b) If your answer to this question is "yes", attempt to define what you think the "work ethic" is.

9. Do you believe there is a work ethic in New Zealand?

Yes

No

I'm not sure

10. Do you believe that people who are unemployed are lazy and simply bludge off the State?
Always
Often
Sometimes
Rarely
Never

IN EACH OF THE FOLLOWING FOUR QUESTIONS TICK THE STATEMENT THAT YOU MOST CLOSELY AGREE WTTH.
a) Hard work is a good thing in itself and I enjoy it.
b) Hard work is OK, but I don't let it interfere with the rest of my life.
c) Hard work should be avoided if possible 
12. a) I feel guilty if I am not doing something

b) I do not feel guilty if I am doing nothing.

c) It depends on the situation as to whether

I feel guilty about doing nothing.

13. a) I need to do the best I can in my job, regardless of the pay.

b) The more I get paid in my job, the more I do;

c) Working for a living is unpleasant and I only do what I have to, to get paid.

14. a) I see my work as a vocation

b) I see my job as my life work

c) I see my work as a chosen career

d) I see my work as a self-imposed task.

e) My work simply provides my bread and butter.

f) I see my work as a profession

g) My work is just a job

h) Other (please specify)

15. Do you think that managers have a different attitude from their staff about work?
Yes
No
Sometimes
I don't know

16. Which of the following four statements is the nearest to your belief? (Tick one)
a) Managers work harder and more effectively than their staff.
b) Managers work hard, but waste more time and energy than their staff.
c) Managers work less hard than their staff
d) Managers work at much the same pace as their staff 
17. Which of the following are of importance to you in why you work? (Tick each one according to its level of importance to you)

\begin{tabular}{|c|c|c|c|c|}
\hline & $\begin{array}{c}\text { Little } \\
\text { Importance (a) }\end{array}$ & $\begin{array}{c}\text { Real } \\
\text { Importance (b) }\end{array}$ & $\begin{array}{c}\text { Overwhelming } \\
\text { Importance } \\
\text { (c) }\end{array}$ & \\
\hline Money & & & & (1) \\
\hline Security & & & & (2) \\
\hline Personal fulfilment & & & & (3) \\
\hline Self-esteem & & & & (4) \\
\hline Satisfaction & & & & (5) \\
\hline $\begin{array}{l}\text { Other people's } \\
\text { expectations }\end{array}$ & & & & (6) \\
\hline $\begin{array}{l}\text { Sense of } \\
\text { meaningfullness }\end{array}$ & & & & (7) \\
\hline Companionship & & & & (8) \\
\hline Promoting leadership & & & & (9) \\
\hline Good of the country & & & & (10) \\
\hline Helping other people & & & & (11) \\
\hline $\begin{array}{l}\text { Being able to make a } \\
\text { worthwhile contribution } \\
\text { to society }\end{array}$ & & & & (12) \\
\hline
\end{tabular}

18. If you regard money as one of the real or overwhelming reasons why you work is it because:

(Tick as many answers as appropriate)

a) you have to have money to survive

b) you need money for personal security

c) you need the money to pursue your interests outside of paid work

d) you need the money to obtain the material possessions

which are important to you
e) you need the money to be able to achieve the things which are important to you in life 


\section{HOURS WORKED}

19. On an average how many hours a day do you work for your main employer?

Up to 4 hours

$4-8$ hours

$8-12$ hours

IF YOU WORK OVER 8 HOURS A DAY PLEASE ANSWER QUESTIONS 20 AND 21. IF YOU DO NOT WORK OVER 8 HOURS PLEASE MOVE ON TO QUESTION 22.

20. If you work over 8 hours a day tick yes/no to each of the following

Yes No

It is part of the job to work overtime

I like getting the job finished

I like the work and don't mind staying

I have nothing better to do with my time

I like working at my own pace

Colleagues work over 8 hours so I feel

I should too

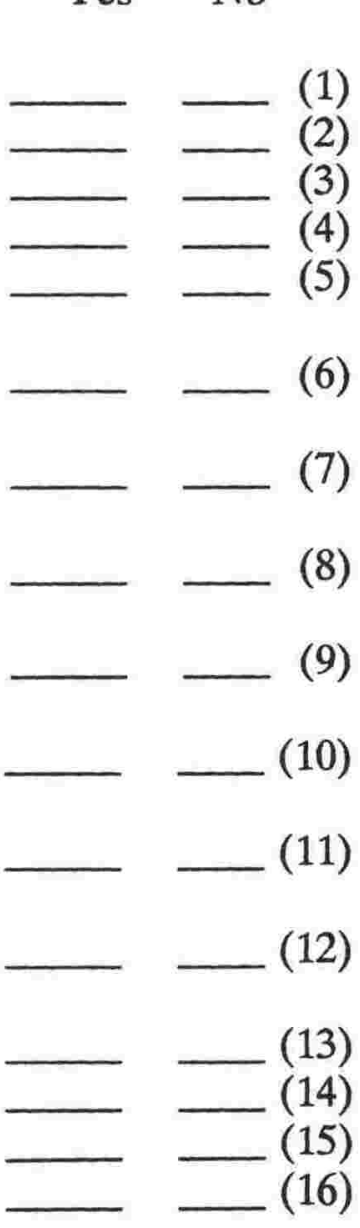

Superiors work over 8 hours so I feel compelled to do the same

It is expected of me but I don't get paid overtime

The organisation is unrealistic about what it expects in the time available

The work is poorly organised and so takes

Meetings drag on and leave little time to do

If I didn't work long hours I would get more

If I didn't work long hours there would be massive foul-ups

If I didn't work long hours I might lose my job

I have a sense of com
Other (please specify)

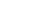


21. If you would prefer not to work 8-12 hours how do you feel about working long hours?

(Tick the statement you most closely agree with.)
a) I would like it to be different
b) I would prefer a less pressured life which would be better for me and the organisation
c) I get really fed up
d) I accept there is no option even though I don't like it
(e) Other (please specify)

22. a) When you are not working for your main employer how do you spend your time?

(Tick as many as appropriate)

Working part-time for another employer

Working around the home

With friends/family

Playing sport

Doing some hobby

Involvement with clubs and organisations

Doing voluntary work

Other (please specify)

If you have ticked hobbies and involvement in clubs and organisations, please state what these are. 


\section{RELIGION AND WORK}

Because the original concept of the work ethic was linked to Protestant Christianity in particular, the following questions are being asked to determine whether there is any possible relation between work and religion in New Zealand.

23. Do you have any religious affiliation?

Yes

No

Prefer not to answer

IF YOUR ANSWER TO THIS QUESTION WAS "NO" OR "PREFER NOT TO ANSWER" PLEASE MOVE ON TO QUESTIONS 26, 27 AND 29.

IF YOUR ANSWER TO THIS QUESTION WAS "YES", PLEASE ANSWER QUESTIONS 24, 25, 26, 28 AND 29.

24. If your answer to question 23 is "yes" please tick which religious faith you belong to.

Christian

Jewish

Buddhist

Hindu

Moslem

Other (please specify)

Prefer not to say

25. If you are a Christian please tick which denomination you belong to.

Church of England

Roman Catholic

Presbyterian

Methodist

Baptist

Salvation Army

Other (please specify)

Not applicable 
26. Even if you have no religious affiliation now, did you have any of the following religious influences in your upbringing?

(Tick as many as appropriate)

Parents who had some religious affiliation

Grandparents who had some religious affiliation

Friends who had some form of religious affiliation

Church school education

Attendance at some form of religious worship

Other (please specify)

Prefer not to answer

27. If you have no formal religious affiliation which of the following statements do you most closely agree with?

(Tick one)

a) There is some greater power than humanity

b) There is some greater power that motivates me strongly in life

c) I have a private, personal, intimate and deep spirituality that is not dependent on any particular religious affiliation

d) I have a form of religious belief but I do not attach myself to any particular religion

e) I am an ethical person but I do not believe in a power greater than humanity

f) I prefer not to answer

g) I do not agree with any of these statements

(If you have some form of spirituality or beliefs that are not covered by the above statements that you would like to specify, please do so.) 
28. If you have a religious affiliation do you believe this makes a difference to your attitude towards work?

Yes

No

Why should it?

Unsure

If your answer is "yes", please try to explain why.

29. Do you believe that worldly success (eg occupational and educational, materially) may be considered as God's reward?

Yes

No

Sometimes

I don't know

\section{E. GENERAL EMPLOYMENT}

30. If you had a choice which of these characteristics would be important to you in picking a new job?

(Tick as many as appropriate)

Making a lot of money

Chance to be creative

Being helpful to others

Avoiding high pressures

Working with ideas

Freedom from close supervision

Providing leadership

Working with people not things

Adequate remuneration

Problem solving

None of the above

Other (please specify) 
31. In today's economic climate in New Zealand are you aware of being fearful of possible unemployment for yourself?

(Tick the statement that you most closely agree with)
a) I am afraid of becoming unemployed.
b) I am not afraid of becoming unemployed.
c) I have not seriously considered
the possibility of unemployment.
d) I'm not sure how I feel about it

32. How do you think the current unemployment figures affect the way you approach your paid employment?

(Tick those appropriate)

I work harder to keep my job

I work harder and make sure people know how useful I am.

I work harder and try to cover up my mistakes to look better

I work harder and point out the deficiencies of my workmates

I keep an ear open for other opportunities

I spend a lot of time "guarding my back"

It makes little or no difference to my work

I probably work less hard as I have lost my incentive

I work harder, but for myself not my employer

Other (please specify)

33. Overall, how do you feel about your job?

(Tick one)

I love it

I am enthusiastic about it

I like it very much

On the whole I like it

It doesn't "get" me one way or the other

I don't like it/I hate it 


\section{F. WORK IN MAF}

34. Do you believe that MAF exists to serve
a) the needs of the agricultural and fisheries sectors in New Zealand?
b) the politicians

(Tick one)

35. Do you see MAF as ultimately caring for the environment in New Zealand?

$$
\begin{aligned}
& \text { Yes } \\
& \text { No } \\
& \text { On the whole } \\
& \text { Unsure }
\end{aligned}
$$

36. MAFs Mission Statement says that MAF exists "to develop and help sustain the land and water resources vital to the growth of New Zealand's economy into the 21st century".

Do you believe that what you are doing in your job at MAF helps to bring this about?

$$
\begin{aligned}
& \text { Yes } \\
& \text { No } \\
& \text { Indirectly }
\end{aligned}
$$

37. Why do you work for MAF?

(Tick all those which are appropriate)

It's a job

Belief in what MAF is doing

Expertise in the areas of agriculture and fisheries

Couldn't get work elsewhere

Feeling that MAF is the "right" place to work

Drifted in - there was a job available

Belief that MAF is a meaningful organisation

None of the above

Other (please specify)

38. Which of these statements do you most identify with?

(Choose only one)

a) I am truly committed to my job and MAF

b) I am committed to my job rather than MAF

c) I am committed to MAF rather than my job

d) I am not committed to my job or MAF 
39. How have the changes to MAF's structure since 1987 affected your attitudes? (Tick as many as appropriate)

My level of commitment to MAF has dropped

I work harder and longer hours

Change is a challenge to me

I believe the "old" MAF was better

I have a greater commitment to MAF

I'm so fed up with change that I have lost my enthusiasm

The changes haven't affected my attitudes

I work less hard and shorter hours

Other (please specify)

40. On the whole do you enjoy working for MAF?

Yes

Mostly

Sometimes

No

Thank you for your time and responses.

If you have any further comments to make about your attitudes towards your work, or on the work ethic, please do so. 


\section{F. WORK IN DSIR}

34. Do you believe that Geology and Geophysics exists to serve

a) the needs of the sectors of our economy concerned with geological and

geophysical knowledge of New Zealand?

b) the politicians

35. Do you see Geology and Geophysics as ultimately caring for the environment in New Zealand?

Yes

No

On the whole

36. Geology and Geophysics Mission Statement says that the organisation exists "To contribute to the economic and social development of New Zealand's territories by conducting strategic research, developing technologies and delivering services which provide a scientific basis for the:

- advancement of the understanding and documentation of geological and geophysical materials and processes;

- location and effective management of mineral, energy and groundwater resources;

- $\quad$ assessment and mitigation of geological hazards;

- application of geoscience to wise land use and environmental management".

Do you believe that what you are doing in your job at Geology and Geophysics helps to bring this about?

Yes
No
Indirectly

37. Why do you work for Geology and Geophysics?

(Tick all those which are appropriate)

It's a job

Belief in what Geology and Geophysics is doing

Expertise in the areas of geology and geophysics

Couldn't get work elsewhere

Feeling that Geology and Geophysics the "right" place to work

Drifted in - there was a job available

Belief that Geology and Geophysics is a meaningful organisation

None of the above

Other (please specify) 
38. Which of these statements do you most identify with?

(Choose only one)

a) I am truly committed to my job and GEO

b) I am committed to my job rather than GEO

c) I am committed to GEO rather than my job

d) I am not committed to my job or GEO

39. How have the continual changes in DSIR over the last few years affected your attitudes?

(Tick as many as appropriate)

My level of commitment to DSIR has dropped

I work harder and longer hours

Change is a challenge for me

I believe the old ways were better

I have a greater comitment to DSIR

I'm so fed up with change that I have lost my enthusiasm

The changes haven't affected my attitudes

towards my work

I work less hard and shorter hours

Other (please specify)

40. On the whole do you enjoy working for GEO?

Yes

Mostly

Sometimes

No

Thank you for your time and responses

If you have any further comments to make about your attitudes towards your work, or on the work ethic, please do so. 


\section{APPENDIX 3}

\section{The Geophysics - a parable}

On an island in a tranquil green sea dwelt the Geophysics. They were not hewers of wood or drawers of water - neither did they spin anything except palaeomagnetic samples. Yet they prospered on their island. They spent their time, all day long, every day, playing a game called science. As they played, they learned some worthwhile and interesting things about the earth and they shared this knowledge with the mainlanders, who were pleased enough with this to send provisions of bread and milk to the island so that the Geophysics could keep playing at science and tell them more things about the earth. The Geophysics indeed became so proficient at science that players from elsewhere in the world would come to discuss the game with them.

The Geophysics were happy. The mainlanders were happy. But one day, Roger, a prophet from among the mainlanders, spoke up and said: "The Geophysics are not accountable!" The mainlanders looked at each other and were sore afraid to ask what "accountable" meant.

The prophet Roger went on: "These Geophysics who take our bread and milk must stop wastefully playing science and start achieving Objectives. And they must stop idly telling us what they know and sell us technology instead. And to make sure that they do this, we must no longer give them bread and milk, but only bread. And easy on the bread."

Now the Geophysics prospered no longer. Some went hungry and left the island. The 
Geophysics held a council of elders. To appease Roger, they called it a Programme Leaders' meeting. They said to each other: " Let us tell the mainlanders that we will indeed achieve objectives. We can really keep on doing science - they won't know any better. But we will also tell them that we won't tell them any more about the earth unless they give us bread."

Now it came to pass that there was a famine in the land, and bread was scarce. The prophet Roger put aside his sackcloth and ashes, put on a grey suit, and opened a bakery. A new prophet, Ruth, arose from amongst the mainlanders. Ruth turned her wrathful eye upon the Geophysics and said: "The Geophysics are not profitable! They must send back a portion of the bread they receive."

Now in the same sect as Ruth, there was a seer named Simon. Simon thought about Ruth's words and had an idea. He said: " Let us build a causeway to the Geophysics' island so that the mainlanders and the Geophysics will mingle and the Geophysics will learn our ways."

And so it came to pass that the causeway has been built and soon there will come to the Geophysics' island from the mainland consultants and Ministerial advisers and beancounters. And they will mingle with the Geophysics, and try to teach them how to achieve their objectives.

But the Geophysics are not dismayed. They have discovered how to keep the mainlanders' scribes and pharisees happy. Whenever these mainlanders call, the 
Geophysics give them Reports. The Reports are very large and very complex and the scribes and pharisees have to go away for a long time to read them. And they don't understand them anyway. So they have to come back and ask for further Reports.

Now it annoys the Geophysics that they have to waste time writing reports for the scribes and pharisees when they should be doing science. But they endure it and hope one that day the scribes and pharisees will get bored with Reports and leave the Geophysics to get on with their game.

Euan Smith

Group Manager, Earthquake and Ground Movement Hazards, Institute of Geophysics and Nuclear Sciences.

28 June, 1992.

(Euan presented this "parable" at a function held to "farewell" DSIR Geology and Geophysics. I have used it here with his permission. I believe it is a fine parody of the way many scientists felt by July 1992.) 


\section{APPENDIX 4}

Definitions from 1991 MAF and DSIR GEO survey on the meaning of the term "work ethic".

\section{"TRADITIONAL" DEFINITIONS}

- the identification of "work" as a fundamental aspect of life necessary for the common and individual good and advancement

working is a way and part of your life and working hard at one job and to excel in it

- conscientious of work and the notion that work is a proper and worthwhile thing to do

- values

- the knowledge that one must work to the best of ones ability in order to make a living and feed the baby, etc, "six days shalt thou work"

- standard of conduct or morality

- the view that hard work is morally right

honesty

- hard work is morally necessary, good for the character and soul, the only way to succeed

the work ethic is the work philosophy or principle that implies that work is good, is rewarding if high standards are achieved

- honourable and morally correct principles

- work is a good and desirable entity in itself. Everyone who is able should work approximately 40 hours work for 40 years 
- Jude's Christian belief in riches and God's reward, refined by the Christian "Protestant Work Ethic"

- working within defined principles

- dedication to the job

- code of conduct and standards

working hard and to a high professional standard

attitude toward your work and the choice to perform for the common good of all

- the degree an individual believes in working to capacity

- honest day's work for honest day's pay (Note: This statement occurred another 12 times)

working within moral guidelines

- the work ethic is the belief that work is good and idleness is evil, and that those who work hard will be rewarded

how people approach their work, commitment, how hard they work, do they always aim to do the job as well as possible

work ethic is the personal attitude to work and the role it plays in one's life

- attending and carrying out your prescribed work in a manner that is morally acceptable to your own conscience

a person's duty to himself, his country and his "God" to work for the betterment of society and his family

it's a persons approach to their work - standards, ideals, moral principles, punctuality, rules of conduct, duty etc

the principles or habits that you follow or guide you in your work 
- self imposed discipline

- belief work is a positive and worthwhile activity which gives satisfaction to the worker

a positive personal response, good work performance

commitment to the job

- satisfaction from work

- good work ethics, hard working

wanting to work and being conscientious about your work

- setting a certain standard

- the belief that to work or hold down a job is a good thing and that one should do their best in that job or work

also the concept that "work" is doing things for pay and for someone else not me

- the reason underlying why people work and how much they put into their work

taking pride in your work can be taken too far so work is more important than recreation and life

- your mental attitude regarding your ability to "want" to go to work each day for whatever reason

- attributable to culture, religion etc

- belief that working hard to the best of one's ability with the sense of responsibility is a good thing for self and society

that work is meaningful

- I believe its the principles by which you work eg. if you go to work, to give it your best each day you have to have a good work ethic 
- to carry out your job to the best of your ability and meet the standards which are expected from you; also how people feel about their jobs

- the manner in which people approach, and manage the way they work

- a sense that to an extent I am what I do therefore it is important to me that I perform my job well measured both by me and by my clients

- rationale and motivation for working and one's whole outlook on life

- the "work ethic" is the priority a person places on their work and result areas as reflected by their conduct/performance

- it's important to work and to work hard to prove to the community and church that one is not lazy but paying one's way in society; worthy of rewards

- do the best you can

- moral, what I as an individual identify as acceptable and morally correct

- a willingness to give the best you can to your job

- honesty in the work arena

- a responsibility to undertake productive/activities to produce an output for personal gain

- quality on the job

- a value that a person or society places on working for an employer or self. People will judge that person on their status of un/or employment

- the concept of giving "value for return" work hard and well - conscientiousness

- the reason/drive that make you work, why you work, for whom you work and in the manner in which you work

- the belief that work is worth doing for its own sake. The desire to contribute to society, to be independent 
the willingness to work for a fair reward

- positive attitude to performance in the job striving to produce high quality work corporate loyalty

- one's attitude to work including how you apply yourself to the job, how you see yourself in relation to employer/employee, how you use work time

- the better your work ethic the more willing you are to slog your guts out for unknown future rewards

- a person's concept of how they should work for the money they are paid

- you must work to be a worthwhile person and work is necessary to achieve any sort of satisfaction in life

- an inner perception of where you think you should be with regard to work

the desire and inherent need to work

- something which motivates you to put the amount of work you do into your job

a responsibility to work to one's best ability for personal satisfaction; sense of responsibility to employer to give value for money

- self motivation to do a job and to succeed at it

- a feeling of obligation to work, first to support your self and dependants and secondly to make a contribution to the well being of the society

- application, conscientiousness and honesty towards work; the minium standards of effort generally accepted both by peers and employers

- all who are capable of doing so should earn their livelihood. A day's work for a day's pay

we all have a "work ethic" (an attitude to work); work is good and good work 
leads to success fulfilment and God's blessing

- giving value for money

- doing a good day's work as a contribution to society (for a good days' pay is often implied)

work is good for the soul

taking pride in the job you do to your best for yourself and for your employer

see productive work as a necessary part of a successful life

- concept that hard work is good for you

a belief and understanding that work is good; brings its own rewards

- willingness to work or want to work

- "work ethic" is an understanding and appreciation that work is a necessary component of personal existence; it has a value

- the willingness to work to the best of your ability; a belief in work as something worthwhile

to work to the best of your ability

the ratio of work completed or undertaken to the reward received; ratio of quality of work performed to reward received; perceived worth of work

keeping work up to a standard

working hard

need to work hard

that the individual or society on a whole benefit from the individual being involved in a work

- the belief that people want to work or need to work to feel that they are productive people in society 
- a belief in the value of productive work

a belief that work is necessary/beneficial to society; that work should be conducted to the best of my ability and that I benefit in various ways

a standard of behaviour appropriate to your working environment

- belief that hard work is good in itself

the requirement that you should be gainfully employed at all times and the associated result if you are into working hard and to be rewarded

- a belief that what you are doing is worthwhile for its own sake; that it is of value to others and a hope that it is rewarding to yourself

to do what you do to the best of your ability with integrity and honesty

no work, no pay

- the need to be in paid work and to perform that work to a standard determined by oneself, one's boss or one's peers

- belief in a commitment to work motivated by the greater good or different to personal gain

- the attitude brought to the workplace and attitudes to work verses personal life

- a belief that work is morally good

how people view their work (employment) in relation to the rest of their life

- the work ethic covers all the beliefs we have about paid and unpaid employment, what is work, how much is good for people and society

- belief in the value of work not just or necessarily for reward but as an end in itself

attitude, diligence and sense of responsibility with respect to the workplace and work context; acknowledgement that one must work to live 
that one works to the best of our abilities

- doing a good day's work as a contribution to society (for a good day's pay is often implied)

how one applies oneself to the job

- the attitude of doing a good job at whatever you are doing; of doing your best

- a sense of responsibility to support oneself and one's dependants by working, learning and working hard and conscientiously

- work ethic to me is the belief that we have a responsibility to work for the good of the community of which we are a part

- a set of beliefs about the place of 'work' in life

- the motivation for people to work

working hard

work codes and principles

- peoples' attitude towards work, the importance they give, and commitment they are prepared to make, etc

- it is the belief that a person should, if sound in mind and body, contribute to society in general by being employed and supporting him/herself

method or style of work

work ethic is believing that hard work is essential for personal family and social purposes that it is dominant and can be an end to itself

- working because one wants to work

all who are capable of doing so should earn their livelihood. A day's work for a day's pay 


\section{MANAGEMENT IDEOLOGY DEFINITIONS}

- a set of unstated guidelines or rules that exist that set the boundaries of behaviour between people and organisations in business relationships

- the work related culture that an individual or group adopt and strive towards for the betterment of employer, employee, company etc

quality wages, conditions, management, work output

work ethic may be considered as the individual's loyalty to their employer which is reflected in their productivity and attitude

- not a form I related easily to but having a satisfactory working environment/conditions and believing that managers care about staff is what I relate to

- moral principles/guidelines installed in the workplace and adhered to by staff/environment

- being a responsible employee

treating of people in their work place. Type of work environment in which one works

a statement of rules of conduct

- attitude to work and how responsible you feel towards the job and your employer

attitudes, values, aspirations on a personal basis, within the workplace contact

- desire to perform work that is of value to the organisation/employers for one's own satisfaction and preferably financial remuneration

- working responsibility for employer or oneself 
- the agreement you enter into with the organisation or your employment agreeing to do a fair day's work for a fair day's pay

- a work places' set of moral values, attitudes in relation to everything associated to the business

- responsibility to your employer and fellow worker

- having a work environment which is fair and equal to all and being a fair and equal person to my workmates

- code of conduct under which you work showing respect for your employer and place of employment how you expect to be treated

the concept that 'work' is doing things for pay and for someone else, not me

- attitude to work contribution by employee as part of environment contract

- achieving your negotiated outputs

- rules of conduct/loyalty to the organisation

- work values existent within an organisation

- the unspoken rules in the workplace

the willingness to work for a fair reward

- a code of practice to ensure the highest level and most suitable result is achieved by following the rules set out by the administration

- the way people in the organisation hold the attitude of individuals

- positive attitude to performance in the job striving to produce high quality work corporate loyalty

- one's attitude to work including how you apply yourself to the job; how you see yourself in relation to employer/employee; how you use work time

- attitude to job fellow workers, management and company 
- code of conduct, set of rules, positive or negative

- an understanding of work discipline defined by the employer and undertaken to a standard determined by the employer

a responsibility to work to one's best ability for personal satisfaction; sense of responsibility to employer to give value for money

- application, conscientiousness and honesty towards work; the minium standards of effort generally accepted both by peers and employers

the loyalty to the workplace and the organisation

- giving value for money

taking pride in the job you do. Do your best for yourself and for your employer

- attitude to job and employer

it is the integrity and loyalty shown in the workplace between employer and employee and visa-versa

a good understanding or perception of what is acceptable effort and conduct in the place, and it relates to conscientiousness loyalty

- the 'moral' stand of an employee regarding how one conducts oneself in delivering 'work' to the employer

the need to be in paid work and to perform that work to a standard betterment by oneself, one's boss or one's peers

- relationship between employer and employee; loyalty, devotion to work, trust on both sides

- commitment to good and honest conduct as employee and to upholding professional standards of employing organisation

- the degree to which a person feels committed to their work/employer in terms 
of trust/loyalty

- attitude towards working towards employer loyalty integrity

- loyalty and commitment to the employing organisation which takes precedence during the stipulated working hours

- rules governing responsibility behaviour etc, between employer and employee - the code of practise in the workplace and how different situations are handled

\section{DEFINITIONS PERTAINING SPECIFICALLY TO ATTITUDE}

- correct work morals and attitude

- your approach and attitude to work

- attitude to work - to time and effort put into work

- I believe 'work ethic' can be defined as the attitude, commitment and carrying out

- an attitude to or philosophy of work

- attitudes and principles relation to work

your attitudes and beliefs about working

- attitude to work and how responsible you feel towards the job and your employer

- attitudes, values, aspirations on a personal basis, within the workplace contact

a person's altitude to work has to do with motivation and effort; person's perception of work

attitude and approach to work

- attitude towards paid working environment 
- attitude towards the job

one's feeling towards work that is reflected in both one's attitudes and how one physically performs 'work'

it is the prevailing attitude towards work held by a person, group of people, or society as a whole

- attitude to job, fellow workers, management and company

work habits, attitude towards work

- attitudes and willingness to work

- the attitude a person has towards working and to their job

attitude to work standards understanding the concept of work

- attitude to job and employer

- attitude to work individual or collective

- individuals attitude to her/his work and perhaps to work (for pay) in general

attitudes and performance measures up to

- attitude, diligence and sense of responsibility with respect to the workplace and work context acknowledgement that one must work to live

attitude towards working, towards employer; loyalty, integrity

peoples' attitude towards work the importance they give and committment they be prepared to make etc

attitude to job and employer

\section{NOT SO SERIOUS DEFINITIONS}

look after yourself, earn as much as you can in the least time with the least 
effort work for King and Country

- you should work hard, relaxation is not on, get up early, early to bed, shut up and do as you are told, don't complain suppress your real feelings

- Sir Robert (Muldoon) would say 'stupid question'

- driving force to prove your worth by doing your best at your job. I wish I didn't have it!

- don't have time, doing this in a hurry; but I think its something we think we dislike but really need; often don't realise how much until no longer

- jargon used by a particular set of management gurus 


\section{APPENDIX 5}

Four questions were asked in the 1991 survey of MAF and DSIR GEO staff about religious affiliation.

A total $52 \%$ of the respondents admitted to having some religious affiliation. ${ }^{1}$ There were organisational differences as shown in Table 5A.

Table 5A: Religious affiliation

(Percentages given are those for the total responses from each organisation)

\begin{tabular}{|c|c|c|}
\hline & MAF & DSIR GEO \\
\hline Yes & 56 & 43 \\
\hline No & 40 & 57 \\
\hline Prefer not to answer & 4 & 1 \\
\hline
\end{tabular}

Not surprisingly the under 25 age group, showed more tendency to have no religious affiliation, with $58 \%$ having none. The age group to demonstrate the highest level of religious affiliation was the $46-55$ year olds, with $59 \%$ acknowledging their association.

Among the occupational classes common to both organisations, $69 \%$ of managers, and $58 \%$ of management support staff answered that they had some religious affiliation. The technical group had the highest percentage of respondents with no religious affiliation with $53 \%$. This no doubt accounts for the disparity between MAF and DSIR GEO.

1 This is a lower ratio than the $71 \%$ of New Zealander's who indicated in the 1991 census that they had some religious affiliation. (1991 New Zealand Census, Population Overview, p. 36) 
Religious affiliation made little difference to whether respondents had heard of the work ethic or not, and only a slight difference as to how they perceived hard work.

$95 \%$ of those responding that they had some religious affiliation were, as expected, Christian. Among the remaining respondents were Buddhists (1\%), Hindus (1\%), and a small group belonging to unspecified religious groups (2\%). $1 \%$ preferred not to give their religious faith.

The response to the question about Christian denomination is shown below.

Table 5B: Christian denomination (Total percentages of those who responded they had a Christian affiliation, on an organisational basis)

\begin{tabular}{||c|c|c||}
\hline & MAF & DSIR GEO \\
\hline Church of England & 28 & 44 \\
\hline Roman Catholic & 20 & 17 \\
\hline Presbyterian & 25 & 2 \\
\hline Methodist & 4 & 4 \\
\hline Baptist & 4 & - \\
\hline Salvation Army & - & 2 \\
\hline Other & 14 & 2 \\
\hline Not applicable & 5 & \\
\hline
\end{tabular}

A study done in 1987 by John Roberts, which asked the permanent heads of Government Departments about their family religious affiliation, showed that $22.5 \%$ were Church of 
England, 22\% were Presbyterian, 16\% were Roman Catholic, 11\% were Methodist, and $4 \%$ were Baptist. $^{2} 76 \%$ of the permanent heads also responded that participation in religious observances had been a significant part of their early lives. ${ }^{3}$

MAF and DSIR GEO staff were also asked about religious influences during their upbringing, and $29 \%$ of the respondents indicated their parents had some religious affiliation, $16 \%$ that grandparents had some form of affiliation, and $14 \%$ had friends during their upbringing who had a religious affiliation. A further $26 \%$ responded they had attended some form of religious worship during their upbringing, while $14 \%$ had attended church schools. ${ }^{4}$ Although the question was worded differently from that in the Roberts' survey of permanent heads, these results show a significantly lower claim to religious influences in their early lives than demonstrated by Roberts' results.

${ }^{2}$ Roberts, John, Politicians, Public Servants and Public Enterprise, p. 75

3 ibid

4 Respondents were asked to indicate as many of the choices as were appropriate. Percentages therefore were for the total number of responses, rather than the number of respondents. 


\section{APPENDIX 6}

Responses from those in the 1991 MAF/DSIR GEO survey who acknowledged that their religious affiliation made a difference to their attitude towards work.

\section{MAF:}

- Conditioned sense of life purpose puts "work" into context of "living" - a means to an end - a process to better life. (Roman Catholic)

I like to believe I'm here for some purpose. (Church of England)

- If religious beliefs is a way of life then doing a good days work and working heartily unto the Lord or God is a pre-requisite of a "religious" person. (no affiliation but answered)

- Col 3:23,24 (Baptist)

- Duty first (Hindu)

- Preparedness to understand and tolerate systems/people. Understanding of wider issues from outside the work place which can contribute positively and negatively to relationships. (Church of England but doesn't attend)

- God's word says that he who doesn't work doesn't deserve to eat and we reap what we sow. (Worldwide Church of God)

- I attempt to live as God's word directs not to water down the Word. May Proverbs speak of application to work and to shun laziness -Prov 6;6-10; 12:24; 20:4. A man reaps what he sows Gal 6:7-8. A lazy man is not worthy of his food, Prov ?. Work to serve God primarily. In doing so you will serve man. (No specific denomination although attends Open Brethren/Baptist fellowships) - You learn tolerance to other people, so if they upset you with their attitude or 
performance, try to understand why "they" have got a problem. (Roman Catholic)

- I believe that Christianity involves treating people like you want to be treated from day one. Is only one life on earth - it is too precious to waste. People want to live life well but need support, understanding, education, motivation and love. (Church of England but doesn't attend)

- Helps develop principles e.g.. right and wrong, fairness etc. (prefer not to state)

It helps me to be more honest in my work. (Roman Catholic)

- Ephesians 6:5; Col 3:22 (Pentecostal)

- The Christian philosophy demands all the humanitarian aspects of a wholesome life. It says treat people well and they will treat you well in return. (Church of England)

- You think of others more and try to help them (Roman Catholic)

- My religion teaches me to be honest, true, chaste, benevolent, virtuous and in doing good to all men. We follow the admonition of Paul. I believe that it is a blessing to work and we are commanded by Our Father in Heaven to work - By the sweat of thy brow shalt thou eat thy bread all the days of thy life. (Church of the Latter Day Saints)

- Because work is part of life, and I live my life as a Christian. (Church of England)

- It keeps me honest, tactful, caring and conscientious (Roman Catholic)

- As a Christian I must serve God here on earth to the best of my ability. I have the honour of serving Him here on earth. (Open Brethren)

- Opportunity to share the gospel and show the difference its made in my life. 
(Assembly of God)

- God requires Christians to do all as if for Him - I do my best for God and "render unto Caesar what is Caesars" - fair days work for fair days pay. (Open Brethren)

- By being honest with myself and clients (Presbyterian)

- My "religion" relates to every aspect of my life - I see my work as a creative activity (in the human sphere of action!) as it is part of the Christian life to be creative, in the image of the Creator. (Presbyterian)

- As a consultant realise clients have different values and beliefs - work is tailored to meet these. (Roman Catholic)

Sets standards in life for you. (Church of England)

- Although you work for an employer ultimately you are responsible to God. (Assembly of God)

- Biblical principle. Bible has a lot to say about our responsibilities to employers and attitude to work. (Presbyterian)

I have a more positive outlook. (Church of England)

Because I believe God has called me to this job to be His ambassador and spokesman, and to be effective revealing his nature through my job, professionalism (and personal integrity) to others associated with me either directly or otherwise. (Assembly of God)

- Honest endeavour provides satisfaction, and one can see the results or the change that occurs as a consequence. (Presbyterian)

Spiritual help to overcome problems; changes attitudes in difficult situations. (Baptist) 
- Treat others as you want to be treated yourself (Presbyterian)

I see my work in terms of service to others (-often mutual) and hope in the long run that it will be for the betterment of humanity. (A lofty goal!) (Presbyterian)

I work as if I was working for the Lord Jesus Christ (Pentecostal - New Life Fellowship)

- As an integral part of my life, I want to know I am doing "my best" as part of living with myself. (Roman Catholic)

I I ask for God's help - often at nights when contemplating problems at work. (Roman Catholic)

Religious belief affects your attitude to fellow workmates. (Church of England)

I think being a Christian makes me more aware of doing a good job. Because you can't hide or cheat from God. (Roman Catholic)

It makes a difference to your whole attitude, not just work but life! (Baptist)

- For the good of family and community, society in general. It's church's ethic or expected structure of society. (Church of England)

- My religious values give me support for responsibility and a good attitude to work. My work place is a place to "shine my light" keep a good testimony for Jesus so that you can witness to your workmates. (Pentecostal)

- Gives a sense of meaningfulness and responsibility (Christian but no denomination at the time of questionnaire)

- I was taught if you did not do an honest days work and wasted time, it was the same as stealing because I was taking pay for time I had not worked. (Roman Catholic)

- If I am what I do, then there is a case for "work is worship" (Roman Catholic) 
Work makes a person a co-creator! (Roman Catholic)

- I feel more accountable for my behaviour and seek assistance in my work with prayers from time to time. (Roman Catholic)

- Along the lines of Col 3:22-24, I believe I am working primarily for God, not my employer. Also, from 2 Thess 3:10, those who are not willing to work should not receive reward. (Baptist)

- A religious affiliation affects all areas of ones life. (Prefers not to state but answered question)

- You try to treat people and yourself in a Christian manner (Presbyterian)

- The Calvinistic work ethic which as ingrained in me from an early age. (Presbyterian)

- High personal code of ethics (Methodist)

- I have a reputation of my beliefs to uphold (Pentecostal)

- Very slow to judge people based on single experiences of poor performance (Church of England)

- Appreciation of life's values - honesty, fairness, morals, etc (Roman Catholic)

- It gives a reason for my existence, and how I conduct my life. (Church of England)

- Perhaps a greater concern for well being of others. (Presbyterian)

- As a Christian think that we should consider needs of others before ourselves Christ came to serve and so should we. Also honesty important. My worth is through God and not work therefore status or money not important. God interested in oppressed and therefore I should be prepared to make a stand for oppressed workers and I have no right to oppress others or make judgments on 
basis of colour, creed, race, sex, etc. (Baptist)

- Part of the total influence. (Prefers not to state but answered question)

- If you are really serious about your Christian work then integrity and honesty must be foremost in your work place. A weekly sermon is used partly for the purpose of how we go into the world and spread the gospel by example. (Baptist)

- Convent trained. Parents with very definite Protestant work ethic. (Roman Catholic)

- In whatever I do, I try and do it to the best of my ability in order to please God and set a good example for my faith. (Open Brethren)

- The Ten Commandments set a great standard to live by, to help fellow (?) people and be conscious of the affect and influence one has. (Roman Catholic)

- Christian faith demands rendering to Caesar the things that are Caesars i.e.: a good days work for a good days pay. (Church of England)

- It gives one a belief of being as one with your co-workers. (Church of Latter Day Saints)

\section{DSIR:}

- Sense of responsibility to employer; moral concern for workmates; try to deal from Christian perspective; my actions reflect my faith. (Roman Catholic)

- Do unto others as they would do unto you. Adopt an honest approach in all dealings. Give value for money (i.e. salary) (Methodist)

I believe in doing what is right in life generally, and my perception of what is right is strongly influenced by me deep analysis of various religions, but especially of Christianity, during my formative years. (Church of England) 
- Christian faith gives purpose above and beyond self-fulfilment. (Open Brethren)

- Strongly ingrained work ethic. (Church of England)

- It gives greater appreciation of the human needs/problems/weaknesses in society and that "work" of some sort is necessary for all people so they can have a sense of personal worth. (Presbyterian)

- Programmed upbringing during childhood to young adult is difficult to forget in later adulthood - it becomes a hidden baseline for ethical and social behaviour. (Methodist)

- I'm unsure but tend towards yes. I think that God is an important influence on work - not necessarily paid work - but that God encourages people to work to help themselves and to help others, and discourages laziness and selfishness. (Roman Catholic)

- Reinforces commitment to things other than work i.e. reminds me that there are more important things than work. I think the work ethic is poor theology by the way. Also think that religious belief reinforces ethical behaviour in business dealing and certainly affects my relationships with fellow workers. (Church of England)

Work provides a sense of purpose, discipline and companionship. It also extends you. This is good for the soul...in moderation. (Spiritualism)

- Religion shapes one's character and thus has a direct impact on the person's attitudes towards work. Religion makes me more responsible so that I not only try to achieve the objectives of my work by also achieve them by honest means. (Hindu)

I notice in myself and others in my workplace with religious affiliations a greater 
tendency to accept (even if it is reluctantly) bad work conditions. (Roman Catholic)

- Honour those in authority in all that I do. (Baptist)

- I believe that I shouldn't mind or resent doing unpleasant work when it of service to other workers - making their lives easier or their jobs run more smoothly. (Methodist)

- Stronger acceptance and tolerance of others. (Church of England)

- Designed to work and to find satisfaction in working. Whatever the job is and the boss is like, "Do it as unto God." (Baptist)

- Try to be honest in all matters. (Presbyterian)

Christian beliefs/moral standards also affect one's attitude to work and work ethic. (Presbyterian) 


\section{APPENDIX 7}

Submissions to the Joint Methodist-Presbyterian Public Questions Committee which specifically addressed the issue of the Protestant work ethic in response to the 1990 Occasional Paper The Nature of Work.

- The tone of the document is pessimistic. It talks of the "Protestant work ethic" being a thing of the past. What nonsense! Our current unemployment has been noteworthy only in the eighties and, like the depressions of the $1880 \mathrm{~s}$ and $1930 \mathrm{~s}$, more probably a transitory state. And then, too, better to use the less loaded term of just "work ethic.

- We would not want to lose the idea of responsibility of those with wealth, talents, etc. to use them in God's service which we understand was part of the belief, but we certainly see its inadequacy in our modern situation.

- The Protestant work ethic cannot be reconciled with the reality of modern unemployment.

- How can attitudes be changed?

(1) Negate the Protestant work ethic

(2) Replace this with a theology of caring

(3) Re-affirm Christian principles

(a) Do whatever task to the best of one's ability

(b) Recognise each task for its intrinsic value

(c) Ascribe value to tasks involving caring for others

(4) Learn that recreation and leisure are positive 
(5) It's all right to enjoy oneself

(6) Encourage Christian attitudes in upper management

(7) Develop caring attitudes in the workplace

- It was felt a bit much was laid on the Protestant work ethic and not enough on its origins in other sources such as the Old Testament and aspects of medieval piety, both of which, pre-dated the former. Prosperity as a mark of God's favour was not considered an issue in our churches today.

- Perhaps a name change is needed; instead of everyone expecting to work, we could all be expected to give service to the community.

We should encourage all presbyters to preach about the new "work ethic"....one which acknowledges the worth of all who work to improve society whether paid or unpaid.

- The Protestant work ethic which uses prosperity as a mark of God's favour can certainly no longer be true.

- We see that prosperity as a sign of God's favour is not relevant in the present day situation of job shortage. Good stewardship of our time and talents may not result in prosperity. Recognition of people and their contribution needs to be given in many other ways than by payment of money. 


\section{BIBLIOGRAPHY}

\section{PRIMARY SOURCES}

Birch, Bill

Address to the Southern Regional Public Service Managers, 29 November 1991 (unpublished paper)

Boston, Jonathan Philosophical and Theoretical Underpinnings of Public Sector Reform in New Zealand Wellington, Faculty of Commerce and Administration, Victoria University, September 1989 (unpublished paper)

Church's problem, too

Crosslink, June 1989

Collins, Jane

A long, hard road for the unemployed The Evening Post, November 1, 1988, 7

Department of Scientific and Industrial Research

Annual Reports, 1985, 1986, 1987, 1988, 1989, 1990, 1991

Mission and Goals for DSIR Geology and Geophysics, 1990 (Staff Memo)

Eyles, R. J. $\quad$ Rutherford Waddell: Man and Parish Presbyterian Historical Society, Annual Lecture, 1986

Follow Up Vital To Success

News ITIMS, 3, September 1989, p. 3

Future Conditional. Science, Technology and Society - a Critical Christian View Great Britain: Home Mission Division of the Methodist Church, 1983

Goulter, John

Full Employment by 1995 promised The Evening Post, May 23, 1990

Haden, Frank

So the Earth didn't move after all Dominion Sunday Times, March 11, 1990

Hawke, Gary R. Reform of the Public Sector: Public Choice Theory Impractical Ideology or the Way Forward? New Zealand: Institute of Policy Studies, Victoria University of Wellington, 1989. (Unpublished paper for a Seminar for Senior Management, Ministry of Agriculture and Fisheries) 
Hawkins, Barry $\quad$ Growing despair over jobs The Evening Post, April 20, 1990

Horrex, Philippa Survey of Ministry of Agriculture and Fisheries /Department of Scientific and Industrial Research Geology and Geophysics staff, November, 1991

Institute of Geological \& Nuclear Sciences Limited

Newsletter, Vol 1, No 1, July 1992

Jenkins, Harvey and Jill

The Unemployed - A Biblical Viewpoint Wellington: The Urban Training Centre for Christian Ministry Inc (UTC), 1979

Jobless challenge our attitudes to work

NZ Baptist, October 1984, 6-7

Joint Methodist-Presbyterian Public Questions Committee

The Nature of Work, Occasional Paper No. 1, March 1990

Submissions to Public Questions Committee regarding Occasional Paper No. 1, (unpublished)

The Nature of Work. A Response to Unemployment: The Denial of a Basic Human Right, 1990 (unpublished report)

L'Estrange, John A Christian Reflection on the Meaning of Work Wellington: Inner City Ministry, 1980 (unpublished paper)

Mabon, John Here to Stay ITIM Contact, August 1989, p.2

Marshall, Peter Christianity and the Economic Order Dunedin: Knox Theological Hall, 1992 (unpublished paper)

Methodist Church of New Zealand

Minutes of NZ Methodist Conferences, 1934, 1935, 1936

Ministry of Agriculture and Fisheries

Annual Reports, 1984, 1985, 1986, 1987-1988, 1988-1989, 1989-1990, 1990-1991, 1991-1992

MAF Corporate Contract, 1991-1992

MAF Corporate Plan, 1988-1989

MAFCorp Contract, 1989-1990

MAFQual Perspective; An Operating Brief, 1989-1990 
One Organisation: Two Different Worlds, Report 1: Gender, Wellington, MAF, 1991

Review of MAF's Mission, Vision, Culture, Values and Strategy, November 1991 (Staff Memo)

The MAF Way, October 1990

Presbyterian Church of New Zealand

Reports of Committees and other papers presented to General Assembly, 1928, 1931, 1932, 1933, 1934, 1935, 1936, 1937, 1945, 1957, 1978, 1980, 1981, 1982, 1983, 1984, 1988, 1990, 1991

Year Book 1989, and Proceedings of the General Assembly 1988

The Outlook, 2 March 1931; 16 March 1931; 20 July 1931; 17 August 1931; 8 February 1932; 7 March 1932; 11 April 1932; 2 May 1932; 1 April 1935; 20 May 1935; 27 May 1935; 3 June 1935 ; 15 July $1935 ; 29$ July $1935 ; 12$ August 1935; 19 August 1935; 9 September $1935 ; 30$ September 1935

\section{Return to Rogernomics}

The Economist, March 23, 1991, 81-82

Richardson, Ruth Address to the Wellington Chamber of Commerce, 27 March, 1991

A State of the Nation Speech to the Lincoln and Hornby Rotary Clubs, 3 April 1991

Roberts, Campbell Employment in the Future All Saints Anglican Church Magazine, Howick: 1986

Roman Catholic Church of New Zealand

Pastoral Address of the Archbishop and Bishops of New Zealand on the Present Economic Crisis, Wellington: June 29, 1931

Smith, Euan

The Geophysies-a parable Wellington: June 1992 (unpublished paper)

State Services Commission

Public Service Code of Conduct Wellington: State Services Commission, 1990 
Structured joblessness a "moral evil"

Unemployment, ITIM, August 1990, 1-4

\section{SECONDARY SOURCES}

Adams, C. Warren A Spring in the Canterbury Settlement London: Longman, Brown, Green, \& Longmans, 1853

Allan, Ruth M. Nelson. A History of Early Settlement Wellington: A. H. \& A. W. Reed, 1965

Alley, R. M. (ed) State Servants and the Public in the 1980's Wellington: New Zealand Institute of Public Administration, 1980

Altick, Richard D. Victorian People and Ideas London: J. M. Dent \& Sons Ltd, 1973

Amirtham, Samuel \& Pobee John S. (eds)

Reflections on doing Theology in Community Geneva: World Council of Churches, 1986

Anderton, Jim

Is there a Better Way? Accent, Vol 3, No.6, August 1998, 6-10

Anthony, P. D. The Ideology of Work Great Britain: Tavistock Publications, 1977

Ansley, Mary Holm Out to Work. Myths and Half-truths about

Unemployment Listener \& TV Times, October 23, 1989

Ausubel, David P. The Fern and the Tiki USA: Holt, Rinehart \& Winston Inc, 1960

Ballard, Paul H. Towards a Contemporary Theology of Work Cardiff:

University of Cardiff/The Industrial Committee, Council of

Churches for Wales, 1982

In and Out of Work: A Pastoral Perspective Edinburgh: The Saint Andrew Press, 1987

Bardsley, Dianne \& Burr, Mike

The Mindless Enemy Auckland: New House Publishers Ltd, 1995

Barker, Lady

Station Life in New Zealand London: MacMillan \& Co, 1874 edn. 
Barrie, W. D. Immigration to New Zealand 1854-1938 Canberra: Australian National University, 1991 (originally written 1938-9, and published as a monograph)

Bassett, Michael The Depression of the Thirties Auckland: Heinemann Educational Books Ltd, 1967

Coates of Kaipara Auckland: Auckland University Press, 1995

Bathgate, Alexander Colonial Experiences; or Sketches of People \& Places in the Province of Otago, New Zealand Glasgow: Capper Press, James Maciehose, Reprint 1974; (C) 1874

Batra, Ravi

The Great Depression of 1990 New York: Simon \& Schuster, 1987 edition

Baum, Gregory (ed) Work and Religion Edinburgh: T.\&T. Clark/Seabury Press, 1980

Baum, Gregory The Priority of Labor New York/Ramsey: Paulist Press, 1982

Beilby, G. T. A Handful of Grain. The Centenary History of the Baptist Union of New Zealand. Vol. 3, 1914-1945 Wellington: New Zealand Baptist Historical Society, 1984

Belch, James Making Peoples. A History of the New Zealanders from Polynesian Settlement to the end of the Nineteenth Century New Zealand: Allen Lane/Penguin Press, 1996

Bell, Daniel

The Coming of Post-Industrial Society London: Heinemann Educational Books Ltd, 1974

The Cultural Contradiction of Capitalism New York: Basic Books, 1976

Bellah, Robert N. The Broken Covenant New York: The Seabury Press, 1975

Bellah, Robert; Madsen, Richard; Sullivan, William M.; Swidler, Ann; Tipton, Steven M.

Habits of the Heart USA: University of California, 1985

Best, Geoffrey

Mid-Victorian Britain 1851-1875 London: Weldenfeld \& Nicolson, 1971 
Binney, Judith; Bassett, Judith; Olssen, Eric

The People and the Land, An Illustrated History of New

Zealand 1820-1920 Wellington: Bridget Williams Books Ltd, 1990, (C) 1993 edn.

Blackburn, Kevin

The Protestant Work Ethic and the Australian Mercantile Elite, 1880-1914 The Journal of Religious History, Vol. 21, No. 2, June 1997, 193-208

Bleakley, David

Work: The Shadow and the Substance London: SCM Press Ltd, 1983

Beyond Work - Free to Be London: SCM Press Ltd, 1985

Bloomquist, Karen L. The Dream Betrayed: Religious Challenge of the Working Class USA: Fortress Press, 1990

Bolger, Jim Bolger - A View from the Top Auckland: Viking, 1993

Bollard, E.G.

Science and Technology in New Zealand. Opportunity for the Future Wellington: National Research and Advisory Council, 1986

Boff, Leonardo \& Clodovis

Salvation and Liberation New York: Orbis Books, 1984

Introducing Liberation Theology New York: Orbis Books, 1987

Boff, Leonardo \& Elizondo, Virgil (eds)

Convergences and Differences Edinburgh: T \& T Clark Ltd, 1988

Boston, Jonathan \& Dalziel, Paul (eds)

The Decent Society? Auckland: Oxford University Press, 1992

Boston, Jonathan, et al (eds)

Reshaping the State, New Zealand's Bureaucratic Revolution Auckland: Oxford University Press, 1991

Boston, Jonathan \& Holland, Martin

The Fourth Labour Government. Radical Politics in New

Zealand Auckland: Oxford University Press, 1987

Bouma, Gary

Beyond Lenski: A Critical Review of Recent "Protestant

Ethic" Research Journal for the Scientific Study of Religion, vol. $12,1973,141-155$ 
Boyd, Judi \& Olssen, Eric

The Skilled Workers: Journeymen and Masters in Caversham, 1880-1914 New Zealand Journal of History, V22 (2) $1988,118-134$

Bradley, Ian The Call to Seriousness. The Evangelical Impact on the Victorians London: Jonathan Cape, 1976

Bradshaw, John New Zealand as it is, London: Sampson, Low, Marston, Searle, \& Rivington, 1883

Brennan, Geoffrey \& Williams, John K. (eds)

Changing Australia: Church Bureaucracies and Political Economy Australia: The Centre for Independent Studies, 1984

Breward, Ian

Rutherford Waddell - A Christian in the World New Zealand's Heritage Sydney: Hamlyn Press, 1971, 1491-1495

Briggs, Asa Victorian People. Some Reassessments of People, Institutions, Ideas and Events 1851-1897 London: Odhams Press Ltd, 1954

Britton, Steve; Le Heron, Richard; \& Pawson, Eric (eds)

Changing Places in New Zealand. A Geography of

Restructuring Christchurch: NZ Geographical Society, 1992

Brookes, Barbara, et al.

Women in History. Essays on European Women in New Zealand New Zealand: Allen \& Unwin, Port Nicolson Press, 1986

Brueggemann, Walter Genesis Atlanta: John Knox Press, 1982

Bryant, George The Widening Gap. Poverty in New Zealand Auckland: Cassell Ltd, 1979

New Zealand 2001 Auckland: Cassell Ltd, 1981

Buller, Rev James Forty Years in New Zealand London: Hodder \& Stoughton, 1878

Burdon, R. M. Outlaw's Progress Wellington: Progressive Publishing Society, 1943

The New Dominion New Zealand: A. H. \& A. W. Reed, 1965 
Burns, Patricia Fatal Success. A History of the New Zealand Company Auckland: Heinemann Reed, 1989

Burns, T. (Rev) Early Otago and Genesis of Dunedin Dunedin: R. J. Stark \& Co, 1916 (Reprinted from the Dunedin "Evening Star")

Butler, Samuel A First Year in Canterbury Settlement New Zealand: Blackwood \& Janet Paul, (C) 1863; 1964 edition

Calvin, John Institutes of the Christian Religion (Vol 2) London: James Clark \& Co., 1953

Campbell, R. J. 'The Black 'Eighties'-Unemployment in New Zealand in the 1880's Australian Economics History Review, V17(2) $1976,67-82$

Carlyle, Thomas $\quad$ Past and Present Oxford: Clarendon Press, 1918, (C) 1844)

Carmody, Denise Lardner

Seizing the Apple New York: Crossroad Publishing Co., 1984

Catherwood, H. F. R. The Christian in Industrial Society London: The Tyndale Press, 2nd Ed. 1966, (C) 1964)

Chadwick, Owen The Victorian Church. Part 1 London: Adam \& Charles Black, 1966

Chalmers, Thomas Problems of Poverty, London: Thomas Nelson \& Sons, 1912

Chapman, Robert \& Sinclair, Keith (eds)

Studies of a Small Democracy Auckland: Blackwood \& Janet Paul Ltd, 1963

Chenu, M. D. The Theology of Work Dublin: Gill and Son, 1963

Chisholm, Rev James Fifty Years Syne, A Jubilee Memorial of the Presbyterian Church of Otago Dunedin: J. Wilkie \& Co, 1898

Clark, Margaret (ed) Sir Keith Holyoake. Towards a Political Biography Palmerston North: The Dunmore Press, 1997

Clarke, John \& Critcher, Chas

The Devil Makes Work: Leisure in Capitalist Britain Great Britain: MacMillan, 1985

Clarke, Roger $\quad$ Work in Crisis Edinburgh: The Saint Andrew Press, 1982 
Collie, J. (ed) Rutherford Waddell. Memoir and Addresses Dunedin: A. H. Reed, 1933

Collins, Chris Playing for Real: Leisure and the Way we Live Directions, Issue No 4, November/December 1989

Collins, Simon Rogernomics. Is there a better way? New Zealand: Pittman, 1987

Condliffe, J. B. New Zealand in the Making London: George Allen \& Unwin Ltd, 1959

Cowrie, William Our Last Year in New Zealand London: Kegan Paul, Trench \& $\mathrm{Co}, 1888$

Cox, Harvey

The Secular City Great Britain: Penguin Books, 1965, 1966

Clark, G. Kitson The Making of Victorian England London: Methuen \& Co. Ltd, 1962

Clark, Margaret; \& Sinclair, Elizabeth

Purpose, Performance and Profit. Redefining the Public

Sector Wellington: Studies in Public Administration, No 32;

Government Printing Office, 1986

Crawford, Scott, A. G. M.

The Inter-Relationship of Recreation and Religion in a Colonial Environment Journal of the New Zealand

Federation of Historical Societies, 2 (4), September, 1986, 15-18

Crocombe, Graham T.; Enright, Michael J.; Porter, Michael E.

Upgrading New Zealand's Competitive Advantage Auckland: Oxford University Press, 1991

Curnow, Allen Collected Poems 1933-1973 Wellington: A. H. \& A. W. Reed, 1974

Curnow, Wystan Essays on New Zealand Literature New Zealand: Heinemann Educational Books, 1973

Dannin, Ellen J. Working Free. The Origins and Impact of New Zealand's Employment Contracts Act Auckland: Auckland University Press, 1997

Daunton, M. J. Progress and Poverty. An Economic and Social History of Britain 1700-1850 Oxford: Oxford University Press, 1995 
Davidson, Allan K.\& Lineham, Peter J.

Transplanted Christianity Palmerston North: Dunmore Press, 1987

Davies, John D. Beginning Now London: Collins, 1971

Davies, Sonja Bread and Roses Auckland: Random House New Zealand Ltd, (C) 1984,1997 edn

Davin, D. M. (ed) New Zealand Short Stories (First Series) Wellington: Oxford University Press, 1976

Davis, Colin \& Lineham, Peter (eds)

The Future of the Past. Themes in New Zealand History

Palmerston North: Department of History, Massey University, 1991

Davis, Hoard \& Gosling, David

Will the Future Work? Values for Emerging Patterns of Work and Employment Switzerland: WCC, 1985

Denson, Donald $\quad$ Settler Capitalism. The Dynamics of Dependent Development in the Southern Hemisphere Oxford: Clarendon Press, 1983

Dickson, Rev John History of the Presbyterian Church of New Zealand Dunedin: J. Wilkie \& Co, 1899

Dickson, Tony \& McLachlan, Hugh

Scottish Capitalism and Weber's Protestant Ethic Thesis

Sociology, Vol.17, No.4, November, 1983, 560-568

Donajgrodzki. A. P. (ed)

Social Control in Nineteenth Century Britain London: Croom Helm, 1977

Doughty, Ross The Holyoake Years Feilding: Ross A. Doughty, 1977

Douglas, Roger Toward Prosperity Auckland: David Bateman, 1987

Completing the Circle New Zealand: Seascape Press, 1996

Driver, S. R. The Book of Genesis London: Methuen \& Co Ltd, 1913

Duncan, Ian \& Bollard, Alan

Corporatization and Privatization Auckland: Oxford University Press, 1992 
Eagles, Jim \& James, Colin

The Making of a New Zealand Prime Minister Wellington:

Cheshire Publishing Pty Ltd, 1973

Easton, Brian (ed) The Making of Rogernomics Auckland: Auckland University Press, 1989

Ebbett, Eve Victoria's Daughters. New Zealand Women of the Thirties New Zealand: A. H. \& A. W. Reed Ltd, 1981

Edwards, Brian Intemperate Outbursts Lower Hutt: Inprint Ltd, 1989

Edwards, James Riot 1932 Christchurch: Whitcombe \& Tombs, 1974

Break Down These Bars New Zealand: Penguin Books, 1987

Edwards, Les Scrim: Radio Rebel in Retrospect New Zealand: Hodder \& Stoughton, 1971

Eisenberger, Robert Blue Monday, The Loss of the Work Ethic in America New York: Paragon House, 1989

Eisenstadt, S. N. The Protestant Ethic and Modernization New York: Basic Books, 1968

Eldred-Grigg, Stevan A Southern Gentry Auckland: Heinemann Reed, 1980 (1989 edition)

A New History of Canterbury Dunedin: John McIndoe, 1982

New Zealand Working People 1890-1990 Palmerston North: Dunmore Press, 1990

The Rich. A New Zealand History New Zealand: Penguin Books, 1996

Elkington, E. Way Adrift in New Zealand London: John Murray, 1906

Emery, Fred; \& Phillips, Chris Living at Work Canberra: Australian Government Publishing Service, 1976

Engstrom, Ted; \& Jurde, David J.

The Work Trap New Jersey: Fleming J. Revell, 1979 
Fairburn, A. R. D. Collected Poems Christchurch: Pegasus, 1966

The Woman Problem and Other Prose Auckland: Blackwood \& Janel Paul, 1967

Fairburn, Miles

\section{Social Mobility and Opportunity in Nineteenth-Century}

New Zealand New Zealand Journal of History, V13 (1), April 1979, 43-64

The Ideal Society and its Enemies Auckland: Auckland University Press, 1989

Nearly Out of Heart and Hope. The Puzzle of a Colonial Labourer's Diary Auckland: Auckland University Press, 1995

Fanfani, Amintore Catholicism, Protestantism and Capitalism London: Sheed \& Ward, 1935

Ferguson, Marilyn The Aquarian Conspiracy London: Paladin, Grafton Books, (C) 1980,1982 edn

Fielden, Kenneth $\quad$ Samuel Smiles and Self Help Victorian Studies, Dec. 1968

Fischoff, Ephraim The Protestant Ethic and the Spirit of Capitalism Social Research, Vol .2, 1944, 53-77

Fitzgerald, Gerald Patrick

Christ in the Culture of Aotearoa-New Zealand Dunedin:

Faculty of Theology, University of Otago, 1990

Fox, Matthew The Re-invention of Work: A New Vision of Livelihood for

Our Time San Francisco: Harper San Francisco, 1994

Frame, Janet

To the Is-land London: The Women's Press Ltd/Hutchinson Group (NZ) Ltd, 1982

Fraser, George Ungrateful People New Zealand: Cape Catley, 1985

Furnham, Adrian The Protestant work ethic and attitudes towards unemployment Journal of Occupational Psychology, 55, $1982,277-285$

The Protestant Work Ethic. The Psychology of Work-Related Beliefs and Behaviours London: Routledge, 1990 
Galbraith, J. K. The Great Crash 1929 USA: Riverside Press, 1954/55

A History of Economics: the Past as the Present London: Hamish Hamilton, 1987

Galbreath, Ross DSIR: Making Science Work for New Zealand Wellington: Victoria University Press, 1998

Garraty, John A. The Great Depression New York: Doubleday, 1987

Garrett, Jane An Artist's Daughter. With Christopher Perkins in New Zealand 1929-34 Auckland: Shoal Bay Press, 1986

Gerth, Hans H. \& Wright Mills, C.(eds)

From Max Weber New York: Oxford University Press, 1946

Gibellini, Rosino The Liberation Theology Debate London: SCM Press Ltd, 1987

Gibson, Leanne Rennie Fritchie. Miss Marple of Management Management, August 1989, 24-26

Giddens, Anthony Modernity and Self Identity UK: Polity Press, 1991

Giddens, Rodney Viewpoint Listener \& TV Times, March 25, 1991, 7

Glasgow, Karen (ed) A New Earth Tauranga: National Council of Women of New Zealand, 1975

Glover, Dennis The Wind and The Sand 1934-44 Christchurch: The Caxton Press, 1945

Godley, John Robert Writings and Speeches Christchurch: Press Office, 1863

Golby, J.M. (ed) Culture and Society in Britain 1850-1890 Oxford: Oxford University Press, 1986

Gray, Alison The Jones Men Wellington: A. H. \& A. W. Reed Ltd, 1983

Greeley, Andrew The Protestant Ethic Sociological Analysis, Vol. 25, 1964, 20-33

Green, Paul F. (ed) Studies in New Zealand Social Problems Palmerston North: The Dunmore Press, 1990

Green, Robert (ed) Protestantism and Capitalism. The Weber Thesis and Its Critics Boston: D. C. Heath \& Co., 1959 
Griffiths, Brian

Gustafson, Barry

Gutierrez, Gustavo

Hall, David

Hamilton, Richard

Handy, Charles

Hardy, Lee

Harris, A.C. (ed)
Morality and the Market Place Great Britain: Hodder \& Stoughton, 1989 edn

From the Cradle to the Grave Auckland: Reed Methuen, 1986

A Theology of Liberation New York: Orbis Books, 1973

The Golden Echo Auckland: Collins, 1971

The Social Misconstruction of Reality New Haven: Yale University Press, 1996

The Age of Unreason Great Britain: Business Books Ltd, 1989

The Fabric of This World USA: William. G. Eerdmans Publishing Co, 1990

Human Resource Management in Public Administration: Te Whakahaere-a-Iwi mo te Katoa Auckland: New Zealand Institute of Public Administration, 1986

Harris, T George \& Trotter, Robert J.

Work Smarter, Not Harder Psychology Today, March 1989, 33

Harrison, J. F. C. The Early Victorians 1832-1851 London: Weidenfeld \& Nicolson, 1971

The Victorian Gospel of Success Victorian Studies, Dec. 1957

Hartley, Nell Colonial Outcasts. A Search for the Remittance Man Morrinsville: Arrow Press Ltd, 1993

Hawke, Gary R. The Making of New Zealand Great Britain: Cambridge University Press, 1985

Hayward, Jeff Back to Fundamentals More Magazine, December 1987, 208-218

Heiges, Donald R. The Christian's Calling Philadelphia: Muhlenberg Press, 1958

Helldorfer, Martin C. Work Trap Connecticut: Twenty-Third Publications, 1995 
Henderson, Alan The Quest for Efficiency: The Origins of the State Services Commission Wellington: State Services Commission, 1990

Herron, David

Alsatia or Utopia? New Zealand Society and Politics in the Eighteen-Fifties Landfall, V13(4) 1959, 324-341

Hight, James \& Straubel, C. R. (eds)

A History of Canterbury, Volume 1: To 1854 Christchurch: Whitcombe and Tombs Limited, 1957

Hilton, Boyd

The Age of Atonement. The Influence of Evangelicalism on Social and Economic Thought, 1785-1865 Oxford: Clarendon Press, 1988

Himmelfarb, Gertrude

The Idea of Poverty New York: Alfred A. Knopf, 1984

Poverty and Compassion. The Moral Imagination of the Late Victorians New York: Alfred A. Knopf, 1991

The De-Moralization of Society. From Victorian Virtues to Modern Values New York: Alfred A. Knopf, 1995

Hobbs, Leslie

The Thirty-Year Wonders Christchurch: Whitcombe \& Tombs Ltd, 1967

Holland, Martin \& Boston, Jonathan (eds)

The Forth Labour Government. Politics and Policy in New Zealand Auckland: 2nd Edition, Oxford University Press, 1990

Holland, Joe Creative Communion. Toward a Spirituality of Work New York: Paulist Press, 1989

Holloway, James Y. \& Campbell, Will D. (eds)

Callings! New York: Paulist Press, 1974

"Hopeful" "Taken In;" Being, a sketch of New Zealand Life London: Capper Press, W. H. Allen, (C) 1887, Reprint 1974

Horrill, Seton Forging a Workplace Mission Red Beach-Orewa: Colcom Press, 1995

Houghton, Walter E. The Victorian Frame of Mind 1830-1870 New Haven: Yale University Press, 1957 
Hucker, Bruce

Hursthouse, Charles New Zealand, the "Britain of the South" London: Edward Stanford, 1861

Inglis, James

Inglis, K.S.

Inkson, Kerr (et al) Theory $K$ Auckland: David Bateman Ltd, 1986

Jackson, H. R.

James, Colin

Jarvis, Adrian June 1988, 11-14 Searle \& Rivington, 1887

Churches and the Working Classes in Victorian England London: Routledge \& Kegan Paul Ltd, 1963 Wellington: Allen \& Unwin NZ Ltd, 1987

The Quiet Revolution Wellington: Allen \& Unwin/Port Nicolson Press, 1986 1992 Wellington: Bridget Williams Books Ltd, 1992

Samuel Smiles and the Construction of Victorian Values
Churches Question Economic Policy Accent, Vol 3, No 4,

Our New Zealand Cousins London: Sampson Low, Marston,

Church and People in Australia and New Zealand 1860-1930

New Territory. The Transformation of New Zealand 1984London: Sulton Publishing, 1997

Jay, Larry R. \& Reed, Michael

Organizing Modernity London and New York: Routledge, 1994

Jenkins, Daniel Christian Maturity and the Theology of Success London: SCM Press, 1976

Jesson, Bruce Fragments of Labour. The Story Behind the Labour Government New Zealand: Penguin Books, 1989

John Paul II Encyclical 'Laborem Exercens' 1981

Johnson, Paul G. Grace: God's Work Ethic Valley Forge: Judson Press, 1985

Jones, Barry Sleepers, Wake! Melbourne: Oxford University Press, 1982

Jones, Bob New Zealand the Way I want it Christchurch: Whitcoulls, 1978

Wimp Walloping Lower Hutt: Inprint NZ, 1989 
Jones, Michael

Reforming New Zealand Welfare. International Perspectives Queensland: The Centre for Independent Studies, 1997

Joyce, Patrick

Work, Society and Politics. The Culture of the Factory in later Victorian England Great Britain: Harvester Press Ltd, 1980

Joyce, Patrick (ed) The Historical Meanings of Work Great Britain: Cambridge University Press, 1987

Juiel, Donald H. Living a Biblical Faith Philadelphia: The Westminster Press, 1982

Kanter, Rosabeth Moss

The New Managerial Work Harvard Business Review, November-December 1989, 85-92

Kappes, C. A. Work Ethic Accent, Vol 3, No 3, April 1998, 5

Kaus, Mickey The Work Ethic State The New Republic, July 7, 1986, 2233

Keating, M. C. P. Clerics and Capitalists. A Critique of Weber's Protestant Ethic Thesis Salford: Dept. of Sociology and Anthropology, University of Salford, 1987

Keiser, Jack

Men at Work London: Epworth Press, 1978

Killinger, Barbara Workaholics. The Respectable Addicts Australia: Simon \& Schuster, 1992

Kim, Hei C.

The Relationship of Protestant Ethic Beliefs and Values to Achievement Journal for Scientific Study of Religion, 16(3), 1977, 255-262

Kitson, Jill

Great Emigrations. Vol 2. The British to the Antipodes London: Gentry Books, 1972

Kriegler, Roy \& Stendal, Grant (eds)

At Work. Australian Experiences Sydney: George Allen \& Unwin, 1984

Kumar, Krishan Prophecy and Progress London: Allen Lane/Penguin Books Ltd, 1978

Lamb, Christopher Belief in a Mixed Society Great Britain: Lion Publishing, 1985 
Landy, Frank J. Psychology of Work Behaviour Chicago: The Dorsey Press, 1985

Lee, John A. Children of the Poor London: T. Werner Laurie Ltd, 1934

The Great Depression New Zealand's Heritage Sydney:

Hamlyn House, 1971, 2269-2275

Roughnecks, Rolling Stones and Rouseabouts New Zealand:

Penguin Books, (C) 1977, 1989 edn.

Lehmann, Hartmut \& Roth, Guenther (eds)

Weber's Protestant Ethic. Origins, Evidence, Contexts USA:

German Historical Institute/Cambridge University Press, 1993

Leitch, Shirley News Talk. Media Stories on Unemployment Palmerston North: Dunmore Press Ltd, 1990

Letters From Otago (1848-1849) Dunedin: Victorian New Zealand-A Reprint Series, No.4, Hocken Library, 1978

Letters From Settlers and Labouring Emigrants in New Zealand Company's

Settlements of Wellington, Nelson and New Plymouth, from

February 1842 to January 1843 London: Smith Elder \& Co, 1843

Llewelyn, Sue \& Osborne, Kate

Women's Lives London: Routledge, 1990

Maccoby, Michael Why Work: Leading the New Generation USA: Simon \& Schuster, 1988

MacDonald, Charlotte

A Woman of Good Character Wellington: Allen \& Unwin/Historical Branch, 1990

MacKinnon, Malcom H.

Part I: Calvinism and the infallible assurance of grace: the Weber thesis reconsidered Part II: Weber's exploration of Calvinism: the undiscovered provenance of capitalism The British Journal of Sociology, Vol.. XXXIX, Number 2, $1988,143-210$

Marais, J.S.

The Colonisation of New Zealand London: Oxford University Press, 1927 
Marsden, Gordon Victorian Values. Personalities and Perspective in Nineteenth Century Society London: Langman, 1990

Martin, John

A Profession of Statecraft? Wellington: Victoria University Press, 1988

Public Service and the Public Servant Wellington: State Services Commission, 1991

Martin, John \& Harper, Jim (eds)

Devolution and Accountability Wellington: Government Print Books, 1988

Martin, John E. Whither the Rural Working Class in Nineteenth-Century New Zealand New Zealand Journal of History, V17(1) 1983, 21-42

The Forgotten Worker. The Rural Wage Earner in Nineteenth-Century New Zealand Wellington: Allen \& Unwin NZ Ltd, The Trade Union History Project, 1990

Marshall, Gordon In Search of the Spirit of Capitalism Great Britain: Hutchinson, 1982

Presbyteries and Profits. Calvinism and the Development of Capitalism in Scotland, 1560-1707 Oxford: Clarendon Press, 1980

Marshall, Paul (et al) Labour of Love: Essays on Work Toronto: Wedge Publishing Foundation, 1980

Mason, Bruce $\quad$ End of the Golden Weather Wellington: Victoria University Press and Price Milburn, 1970 edn

Mason, R. A. K. This Dark Will Lighten. Selected Poems 1923-41 Christchurch: The Caxton Press, 1941

McClenaghan, Jack Travelling Man Auckland: Collins, 1976

McClennan, Roy \& Gilbertson, David Work in New Zealand Wellington: A. H.\&A. W. Reed Ltd, 1984

McClure, Margaret A Civilised Community Auckland: Auckland University Press, 1998 
McCormack, Thelma The Protestant Ethic and the Spirit of Socialism British Journal of Sociology, vol. 20, 1969, 266-276

McEldowney, Dennis (ed)

Presbyterians in Aotearoa 1840-1990 Wellington:

Presbyterian Church of New Zealand, 1990

McInnes, John

The New Pilgrims Australia: Albatross Books, 1980

McKinlay, Peter (ed) Redistribution of Power? Devolution in New Zealand Wellington: Victoria University Press, 1990

McLauchlan, Gordon The Passionless People Auckland: Cassell New Zealand, 1976

The Big Con. The Death of the Kiwi Dream Wellington: GP Publications Ltd, 1992

McLintock, A. H. The History of Otago Dunedin: Otago Centennial Historical Publications, 1949

McGovern, Arthur F.

Liberation Theology and its Critics Maryknoll: New York, Orbis Books, 1989

Means, Richard

Protestantism and Economic Institutions: Auxiliary Theories to Weber's Protestant Ethic Social Forces, Vol. 44, 1966, 372-379

Weber's Thesis of the Protestant Ethic: The Ambiguities of Received Doctrine The Journal for Religion, Vol. XLV, No. 1, January 1965

Meeks, M. Douglas God the Economist Minneapolis: Fortress Press, 1989

Merrington, E. N. A Great Coloniser. Rev Dr. Thomas Burns Dunedin: Otago Daily Times and Widness Newspapers Co. Ltd, 1929

Millen, Julia

Colonial Tears and Sweat. The Working Class in Nineteenth Century New Zealand Wellington: A. H. \& A. W. Reed Ltd, 1984

Miller, John

Early Victorian New Zealand: A Study of Racial Tension and Social Attitudes 1839-1852 Wellington: Oxford University Press, 1958, Paperback edn (C) 1974 
Mitzman, Arthur The Iron Cage: An Historical Interpretation of Max Weber New York: Alfred A. Knopf, 1969

Moltmann, Jurgen On Human Dignity London: SCM Press Ltd, 1984

Morel, Mary

Ethics in the Public Service Service, March/April 1992, 1011

Morrell, W. P. \& Hall, D. O. W.

A History of New Zealand Life New Zealand: Whitcombe \& Tombs Ltd, 1957

Muldoon, R.D. Muldoon New Zealand: A. H. \& A. W. Reed, 1977

My Way New Zealand: A. H. \& A. W. Reed, 1981

Mulgan, John Report on Experience London: Oxford University Press, 1947

Man Alone Auckland: Longman Paul Ltd, C 1972, 1985 reprint

Naisbitt, John $\quad$ Megatrend Great Britain: MacDonald \& Co., (C) 1982, 1984 edn

Neal, Marie Augusta A Socio-Theology of Letting Go New York: Paulist Press, 1977

Nedd, A. N. \& Marsh, N. R.

Attitudes and Behaviour of the Multi-cultural Industrial Workforce in New Zealand Auckland: The University of Auckland (The Department of Management Studies), 1977

Nelson, John Oliver (ed)

Work and Vocation New York: Harper \& Brothers Publishers, 1954

Newman, Katherine S.

Falling from Grace: The Experience of Downward Mobility in the American Middle Class New York: The Free Press, 1988

Newsome, David The Victorian World Picture London: John Murray, 1997

New Zealand Official Year Book 1929 Wellington: WAG Skinner, 1928

New Zealand Official Year Book 1930 Wellington: WAG Skinner, 1929 
New Zealand Official Year Book 1931 Wellington: WAG Skinner, 1930

New Zealand Official Year Book 1933 Wellington: WAG Skinner, 1932

New Zealand Official Year Book 1934 Wellington: G. H. Loney, 1933

New Zealand Official Year Book 1936 Wellington: G. H. Loney, 1935

New Zealand Official Year Book 1993 New Zealand: Department of Statistics, 1993

Nightingale, Tony $\quad$ White Collars and Gumboots: A History of the Ministry of Agriculture and Fisheries 1892-1992 Palmerston North:

Dunmore Press, 1992

Noonan, Rosslyn George Forbes: The Inflexible Conservative New Zealand's Heritage Sydney: Hamlyn, 1971, 2281-2286

Oates, Wayne Confessions of a Workaholic New York: The World Publishing Co., 1971

Obenhaus, Victor $\quad$ Ethics for an Industrial Age USA: Greenwood Press, C1965, 1975 reprint

O'Brien, Karen $\quad$ Woman's Work Dunedin: Caveman Press, 1981

OECD Economic Surveys

New Zealand 1988/1989 France: OECD, 1989

O'Grady, Alison \& Ron

Enough! Accent, Vol 3, No 6, August 1998

Oliver, W. H. The Story of New Zealand London: Faber \& Faber, 1960

Oliver, W. H.\& Williams, B. R. (eds)

The Oxford History of New Zealand Auckland: Oxford

University Press, 1981

Olssen, Erik

The Sweating Agitation New Zealand's Heritage Sydney:

Hamlyn Press, 1971, 1496-1501

The 'Working Class' in New Zealand New Zealand Journal of History, Vol. 8 (1974), 44-60

A History of Otago Dunedin: John McIndoe Ltd, 1984

Olssen, Erik, \& Stenson, Marcia

A Century of Change Auckland: Longman Paul, 1989 
O'Meeghan, Michael Held Firm by Faith Christchurch: Catholic Diocese of Christchurch, 1988

Park, Ruth A Fence Around the Cuckoo Australia: Penguin Books, 1992

Pearson, Bill Fretful Sleepers and Other Essays Auckland: Heinemann Educational Books (NZ) Ltd, 1974

Pelikan, Jaroslav; Kitagawa, Joseph; Nasr, Seyyed Hossein Comparative Work Ethics Washington: Library of Congress, 1985

Pelly, Raymond, (ed) Towards a Just Economy Wellington: The Combined Chaplaincies Victoria University of Wellington, 1991

Perkin, Harold The Origins of Modern English Society 1780-1880 London: Routledge \& Kegan Paul, 1969

Phillips, Jock A Man's Country? Auckland New Zealand: Penguin Books, 1987

Piddington, Ken The Public Service in the Post-Victorian Era Public Sector, V1(2) Spring 1978, 4-6

Piper, Otto A. The Meaning of Work Theology Today, XIV(2) July 1957, 174-194

Christian Ethics London: Thomas Nelson \& Sons Ltd, 1970

Poggi, Gionfranco Calvinism and the Capitalist Spirit. Max Weber's Protestant Ethic London \& Basingstoke: MacMillan Press Ltd., 1983

Polaschek, R. J. Government Administration in New Zealand London: Oxford University Press, 1958

Porter, Frances \& MacDonald, Charlotte (eds)

'My Hand Will Write What My Heart Dictates' Auckland: Auckland University Press/Bridget Williams Books, 1996

Pottenger, John R. The Political Theory of Liberation Theology New York: State University of New York Press, 1989

Pratt, W.T. Colonial Experiences; or Incidents and Reminiscences of Thirty-Four Years in New Zealand (by an Old Colonist) London: Chapman \& Hall, 1877 
Preston, Ronald, H. Religion and the Persistence of Capitalism London: SCM Press, 1979

Purchas, H. T. Bishop Harper and the Canterbury Settlement New Zealand: Whitcombe and Tombs Ltd, 1909

Raines, John C. \& Day-Lower, Donna C.

Modern Work and Human Meaning Philadelphia: The Westminster Press, 1986

Ranby, Margaret The Choice Harvest Field, May 1989, 5

Randerson, Richard Christian Ethics and the New Zealand Economy Wellington: Department of Christian Education Diocese of Wellington, 1987

Hearts \& Minds. A Place for People in a Market Economy New Zealand: Social Responsibility Commission of the Anglican Church in Aotearoa New Zealand and Polynesia, 1992

Rankin, Keith Unemployment in New Zealand at the Peak of the Great Depression Auckland: University of Auckland (Department of Economics), 1994

Reeves, William Pember

The Long White Cloud Australia: Viking, (C) 1898, 1987 edition

Reid, Ian

Fiction and the Great Depression. Australia and New Zealand 1930-1950 Melbourne: Edward Arnold (Australia) Pty Ltd, 1979

Rendtorff, Trutz Ethics (Vol 1) Philadelphia: Fortress Press, 1986

Ethics (Vol 2) Philadelphia: Fortress Press, 1989

Richardson, Alan Genesis I-XI London: SCM Press Ltd, 1953

The Biblical Doctrine of Work London: SCM Press Ltd, (C) 1952, reprint 1954

Richardson, Ruth

Making a Difference Christchurch: Shoal Bay Press, 1995

Roberts, John

Politicians, Public Servants and Public Enterprise Wellington: Victoria University Press, 1987 
Robertson, H. M. Aspects of the Rise of the Economic Individualism Clifton: USA, Augustus M. Kelley, 1973 edn.

Rollo, Arnold

Rose, Michael Re-Working the Work Ethic London: Batsford Academic \& Educational, 1985

Rosenberg, W. Full Employment. Can the New Zealand Economic Miracle Last? Wellington: A. H. \& A. W. Reed, 1960

The Magic Square Christchurch: New Zealand Monthly Review Society Inc, 1986

Ross, Rev C. Stuart Life and Times of D. M. Stuart, D.D. Dunedin: J. Wilkie \& Co., 1894

Roth, Bert

Remedy for Present Evils. A History of the New Zealand Public Service Association from 1890 Wellington: New Zealand Public Service Association, 1987

Routh, Guy

The Origin of Economic Ideas London: Macmillan, 1989

Royal Commission of Inquiry

The State Services in New Zealand Wellington: Government Print, 1962

Royal Commission on Social Policy

Work: Its Nature, Role and Value in New Zealand

Wellington: Royal Commission on Social Policy, 1987

Future Directions. Vol II Wellington: Royal Commission on Social Policy, 1988

Towards a Fair and Just Society Wellington: Royal Commission on Social Policy, 1988

Rutherford, J. (ed) The Founding of New Zealand, (The Journals of Felton Matthew, First Surveyor-General of New Zealand, and his wife 1840-1847) New Zealand: A. H. \& A. W. Reed, 1940

Ryan, Christopher Under Review Service, December 1991, 8-9

Restructuring Science Service, March/April 1992, 4-5

Under Consideration Service, March/April 1992, 8-9 
A Drive for Higher Productivity Service, June/July 1992, 89

Salmond, J. D. New Zealand Labour's Pioneering Days Auckland: Forward Press, 1950

Samuelsson, Kurt Religion and Economic Action London: Heinemann, 1961

Sargeson, Frank A Man and His Wife Christchurch: Caxton Press, 1940

More Than Enough Wellington: A. H. \& A. W. Reed, 1975

The Stories of Frank Sargeson New Zealand: Penguin Books, 1982

Second Sweating Commission

Across the Counter: The Lives of the Work Poor in New Zealand 1990 Wellington: Second New Zealand Sweating Commission, 1990

Seglindo, Juan Luis Liberation of Theology Dublin: Gill \& MacMillan Ltd, 1977

Sennett, Richard The Corrosion of Character: the Personal Consequences of Work in the New Capitalism New York: Norton, 1998

Schaef, Anne Wilson \& Fussel, Diane

The Addictive Organization San Francisco: Harper \& Row, 1988

Scholefield, Guy H. (ed)

The Richmond-Atkinson Papers (Vol 1) Wellington: R. E.

Owen, Government Printer, 1960

Schumacher, E. F. $\quad$ Good Work New York: Harper \& Row Publishers, 1979

Schuster, George Christianity and Human Relations in Industry London: The Epworth Press, 1951

Scott, Donald The Psychology of Work London: Duckworth, 1970

Scrimgeour, C. G., Lee, John A., \& Simpson, Tony

The Scrim-Lee Papers New Zealand: A. H. \& A. W. Reed, 1976

Sharp, Andrew (ed) Leap into the Dark. The Changing Role of the State of New Zealand since 1984 Auckland: Auckland University Press, 1994 

Smith, Harold (ed) The Best in Theology, Volume Three Illinois: CTi, 1989

Smith, Thomas B. The New Zealand Bureaucrat Wellington: Cheshire Publishing Pty Ltd, 1974

Smout, T. C. (ed) Victorian Values. A Joint Symposium of the Royal Society of Edinburgh and the British Academy December 1990 Oxford: Oxford University Press, 1992

Somerset, H. C. D. Littledene Wellington: New Zealand Council for Educational Research, 1974

Soelle, Dorathee (with Cloyes, Shirley A.)

To Work and To Love USA: Fortress Press, 1984

Soper, Eileen L. The Otago of our Mothers New Zealand: (C) 1948, Otago Centennial Historical Publications, Whitcombe \& Tombs Ltd, Reprint Capper Press, 1978

Spoonley, Paul; Pearson, David; Shirley, Ian

New Zealand Society Palmerston North: Dunmore Press, 1990

State Services Commission

Major Changes to Government Science Proposed Service, June 1991, 6-7

Statistics New Zealand Population Overview, (1991 New Zealand Census)

Wellington: Statistics New Zealand, 1994

Employment and Unemployment, (1996 New Zealand Census) Wellington: Statistics New Zealand, 1998

Stout, Robert

New Zealand Cambridge: Cambridge University Press, 1911

Stuart, Julia

"The Future of Work" A Christian Perspective Future Times, Summer 1987/1988, 12-13

Styles, Lawrie

Direction Signs to an Achievable Future Melbourne: InterChurch Trade and Industry Mission, 1982

Sutch, W. B. Poverty and Progress in New Zealand Wellington: Modern Books, 1941

The Quest for Security in New Zealand 1840-1966

Wellington: Oxford University Press, 1966 
Sutherland, Temple Green Kiwi Wellington: A. H. \& A. W. Reed, 1960 edition

Swainson, William. New Zealand and It's Colonization London: Smith, Elder \& Co., 1859

Symanowski, Horst The Christian Witness in an Industrial Society London: Collins, 1966

Tautane, Mara

Trade, Guns and Bibles New Zealand: Mara Tautane, 1976

Tawney, H. R. Religion and the Rise of Capitalism England: Penguin Books Ltd., 1969 edn.

Temple, William Christianity and Social Order London: ShepherdWalwyn/SPCK, CC 1942, 1976 edn

Templeton, Hugh All Honourable Men Auckland: Auckland University Press, 1995

Tennant, Margaret $\quad$ Paupers and Providers. Charitable Aid in New Zealand Wellington: Allen \& Unwin/Historical Branch, 1989

Terkel, Studs

Working USA: Pantheon Books, 1974

Thatcher, Margaret The Revival of Britain London: Aurum Press, 1989

The Advance Guard, Series 2 Dunedin: Otago Daily Times, 1974

The Handbook to the Suburban and Rural Districts of the Otago Settlement

Dunedin: Reprinted from the "Otago News", 1849, Hocken Library Facsimile No.2, 1967

Thomson, Mrs Charles

Twelve Years in Canterbury, New Zealand London: Sampson, Low, San \& Marston, 1867

Thomson, David

A World Without Welfare. New Zealand's Colonial Experiment Auckland: Auckland University Press/Bridget Williams Books, 1998

Thomson, K. W. \& Trlin, A. D. (eds) Contemporary New Zealand Wellington: Hicks, Smith \& Sons Ltd, 1973

Thompson, F. M. L. Social Control in Victorian Britain The Economic History Review, Second Series, Volume XXXIV, No. 2, May 1981, 189-208 
The Rise of Respectable Society. A Social History of

Victorian Britain 1830-1900 London: Fontana Press, 1988

Tillich, Paul

The Eternal Now New York: Charles Scribner's Sons, 1963

Tocker, Alison

What Drives Workaholics Listener, April 16, 1994, 33-36

Toffler, Alvin

Future Shock London: Pan Books Limited, 1970

Torry, Malcom

Basic Income for All: A Christian Social Policy Nottingham: Grove Books Ltd, 1988

Toynbee, Claire

Her Work and His Wellington: Victoria University Press, 1995

Travers, Tim

Samuel Smiles and the Victorian Work Ethic New York: Garland Publishing Inc, 1987

Troeltsch, Ernst The Social Teachings of the Christian Churches (Vol..2)

London: George Allen \& Unwin, 1931 edition

Trollope, Anthony The New Zealander Oxford: Clavendon Press. 1972 (Original 1855)

Trlin, A. D. (ed) Social Welfare and New Zealand Society New Zealand: Methuen, 1977

Twinn, W. J.

The Kiwi and the Work Ethic New Zealand Journal of Industrial Relations, Vol 2(3), Nov 1977, 97-100

Unemployment. Realities and Illusions New Zealand: New Zealand Business Round Table, December 1990

Vest, Norvene $\quad$ Friend of the Soul. A Benedictine Spirituality of Work Boston: Cowley Publications, 1997

Viner, Jacob

Religious Thought and Economic Society Durham, North Carolina: Duke University Press, 1978

Volf, Miroslav Work in the Spirit New York: Oxford University Press, 1991

Vowles, Jack \& Aimer, Peter

Voter's Vengeance Auckland: Auckland University Press, 1993

von Rad, Gerhard Genesis London: SCM Press Ltd, 1972 revised edn 
von Tunzelmann, Adrienne \& Johnston, Jeanette (eds)

Responding to the Revolution. Careers, Culture and

Casualties Wellington: Government Printing Office, 1987

Wagner, Helmut The Protestant Ethic: A Mid-Twentieth Century View

Sociological Analysis, vol. 25, 1964, 34-40

Waldergrave, Charles \& Coventry, Rosalyn

Poor New Zealand. An Open Letter on Poverty Wellington:

Platform Publishing Ltd, 1987

Walker, Simon (ed) Rogernomics. Reshaping New Zealand's Economy

Wellington: Government Print Books, 1989

Walvin, James

Victorian Values USA: The University of Georgia Press, 1978

Ward, W. R. Religion and Society in England 1790-1850 London: B. T. Batsford Ltd, 1972

Warring, Marilyn Counting for Nothing Wellington: Allen \& Unwin/Port Nicolson Press, 1988

Weber, Max Economy and Society USA: University of California Press, 1978

The Protestant Ethic and the Spirit of Capitalism London: Unwin Paperbacks, 1985 edn

Webster, Alan C. \& Perry, Paul E.

The Religious Factor in New Zealand Society Palmerston North: Alpha Publications, 1989

Values and Beliefs in New Zealand. The Full Report Palmerston North: Alpha Publications 1992

Westra, Rinny No Final Verdict Yet! Accent, Vol 3, No 1, February 1988, 16

Whyte, William H. The Organization Man England: Penguin Books Ltd, (C1956, 1960 edn

Wingren, Gustaf Luther on Vocation Philadelphia: Muhlenberg Press, 1957

Wink, Walter Naming the Powers. (Vol 1) The Powers Philadelphia: Fortress Press, 1984 
Wogaman, J. Philip Christians and the Great Economic Debate London: SCM Press Ltd, 1977

Yankelovich, Daniel The Work Ethic is Underemployed Psychology Today, May 1982, 5-8

Yankelovich, Daniel (et al)

Work and Human Values: An International Report on Jobs in the 1980's and 1990's New York: Aspen Institute for Humanistic Studies, 1983

Yorke, A. Tremenheere

The Animals Came First Auckland: Heinemann, 1980

Young, F. J. L. Active Employment Policy: The Challenge of Full Employment in a Changing Society (Occasional Papers in Industrial Relations, No. 15), Wellington: Victoria University, 1975 